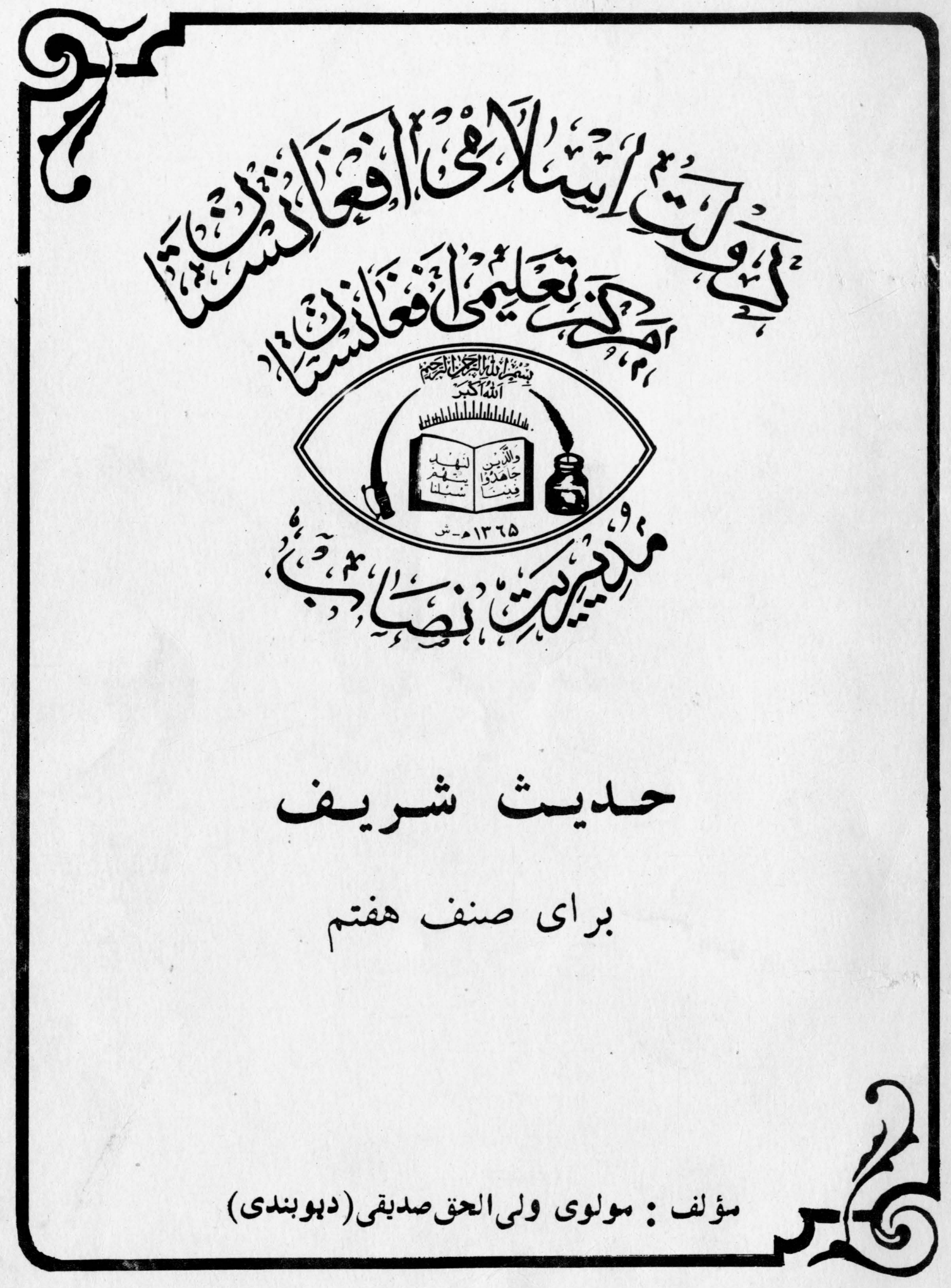




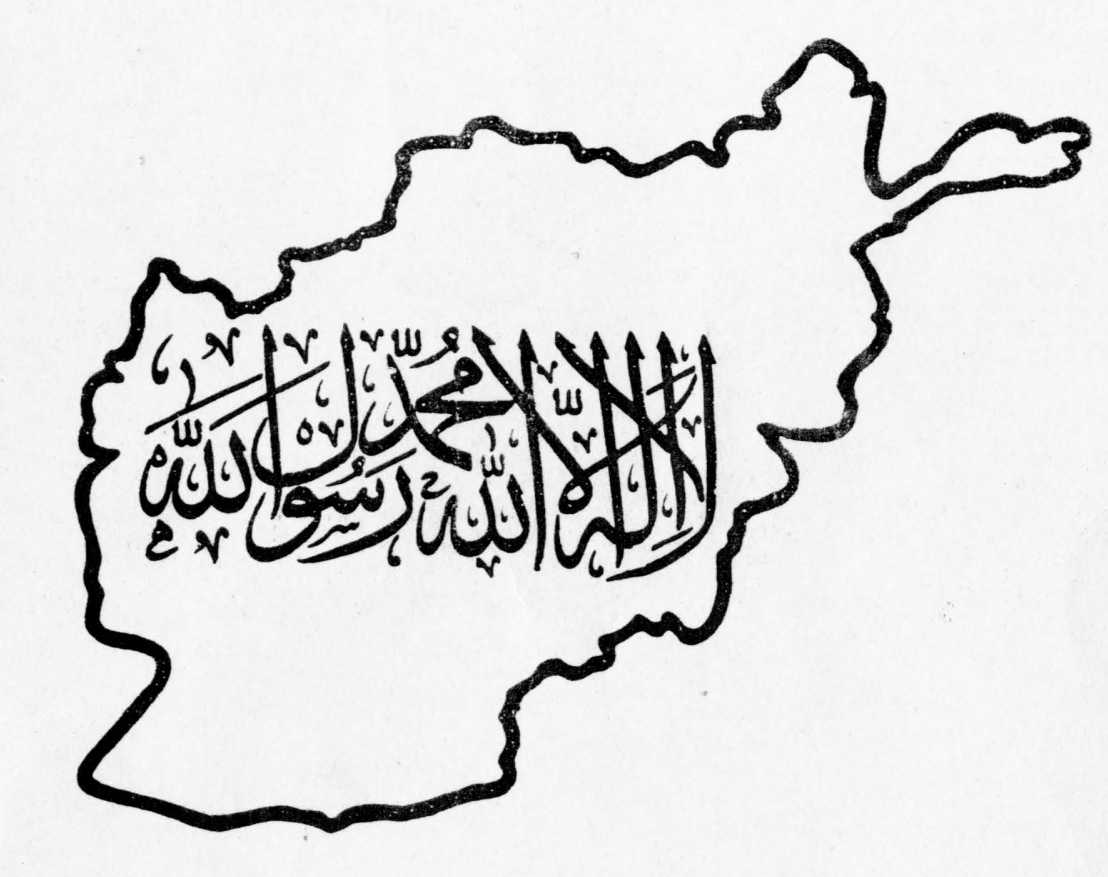




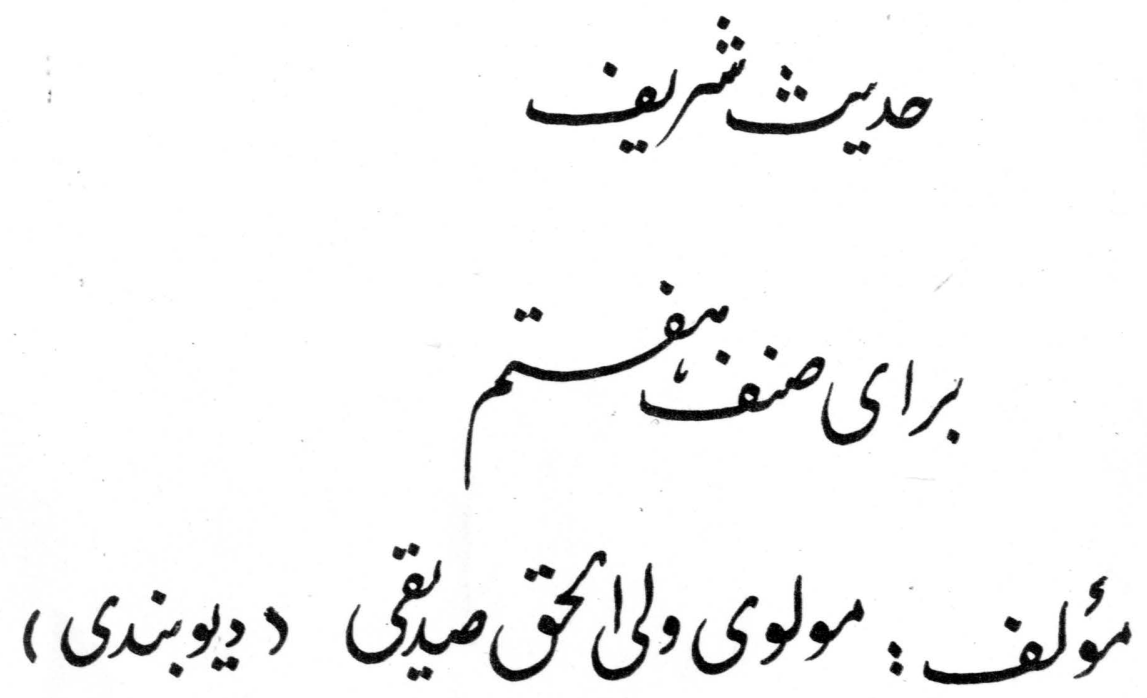




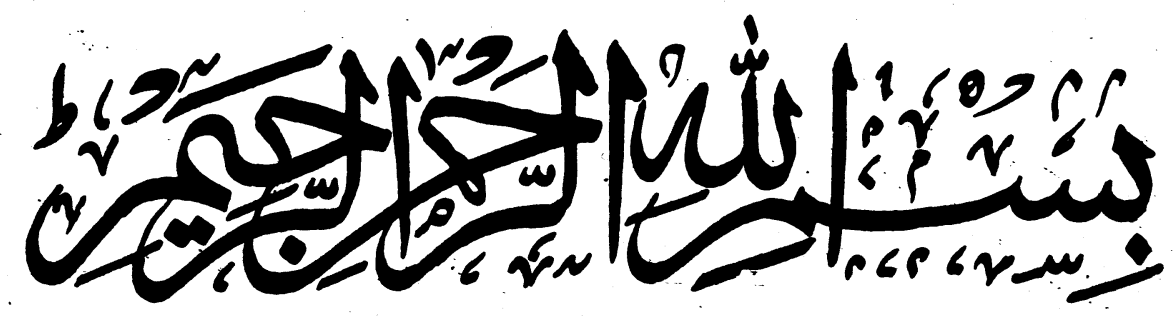



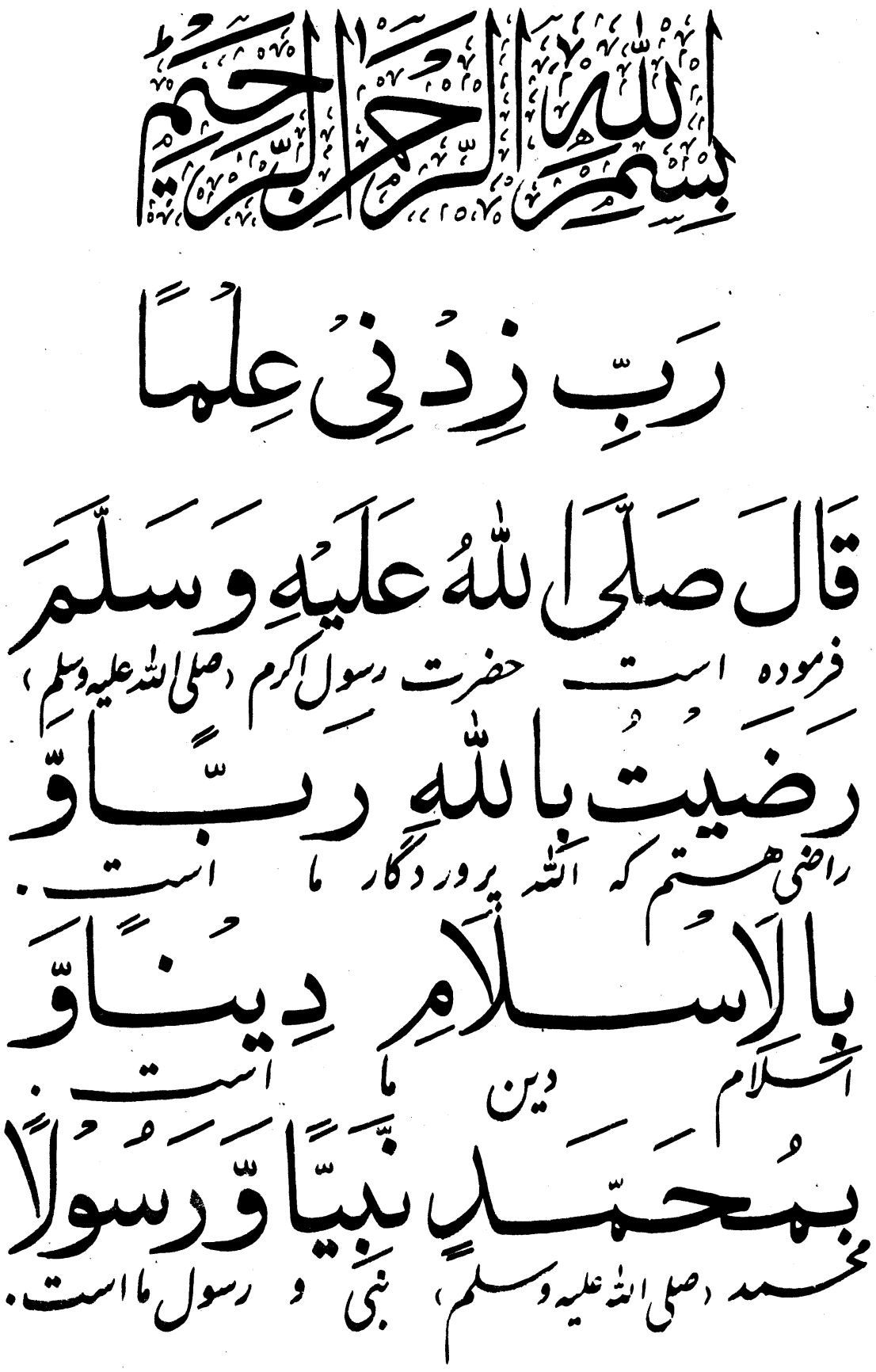


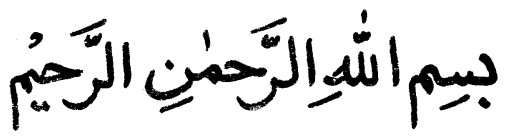

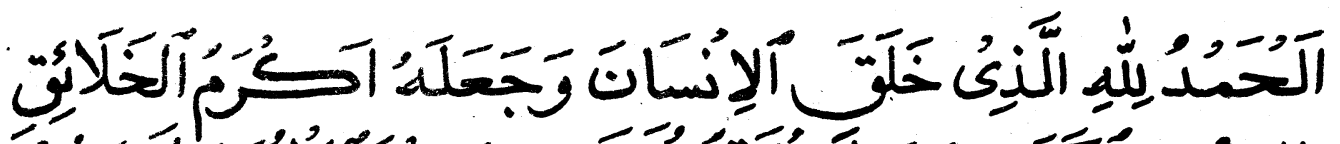

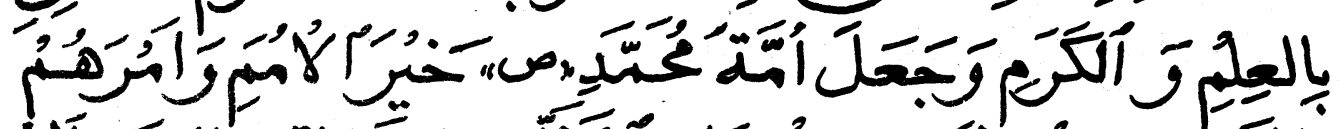

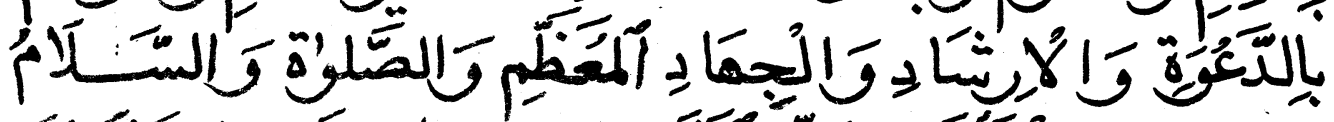

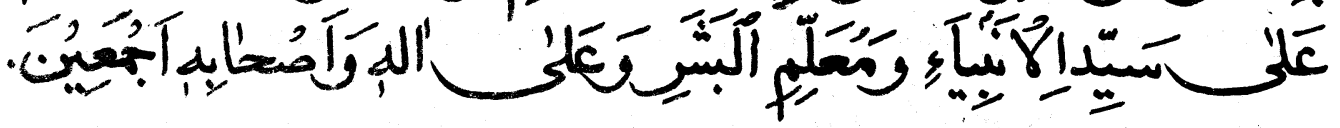

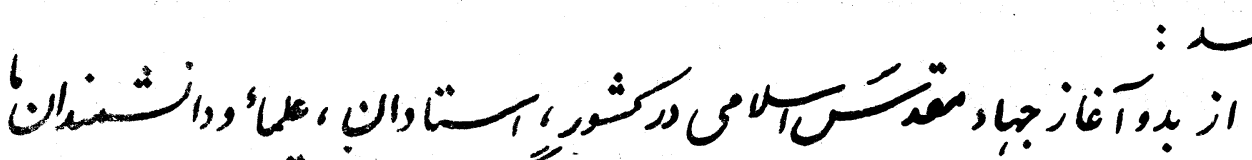

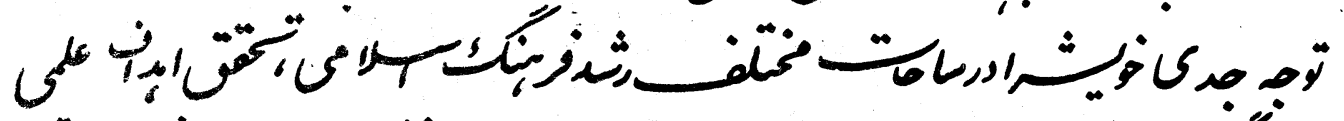

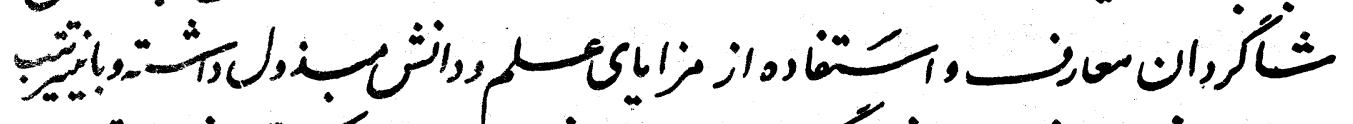

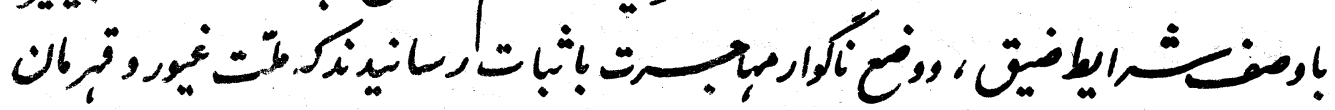

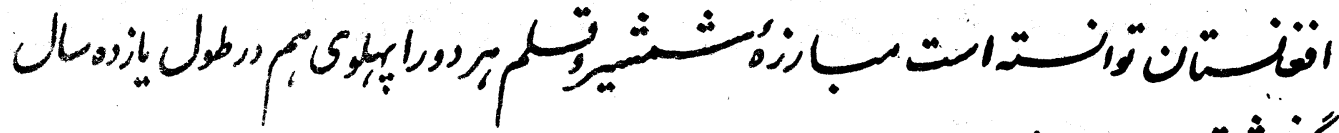

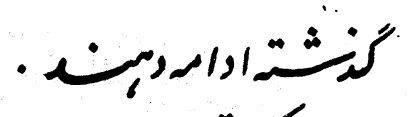

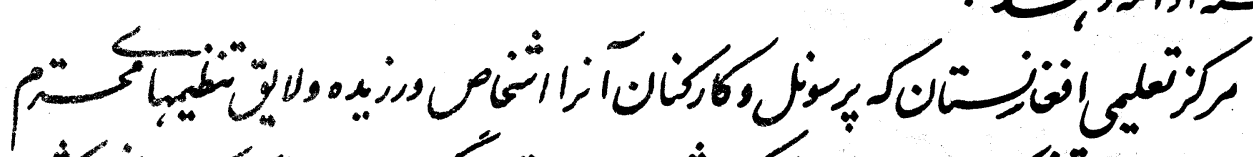

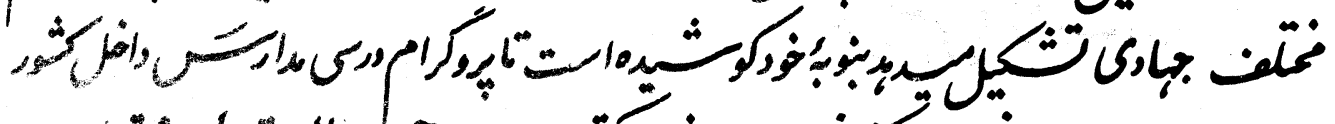

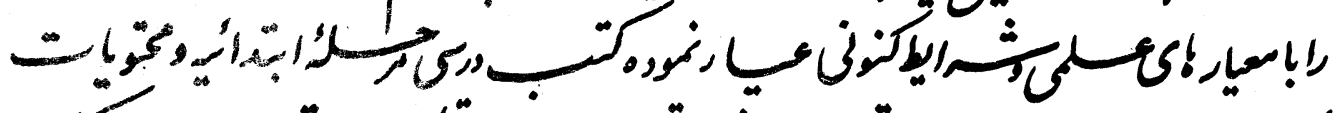

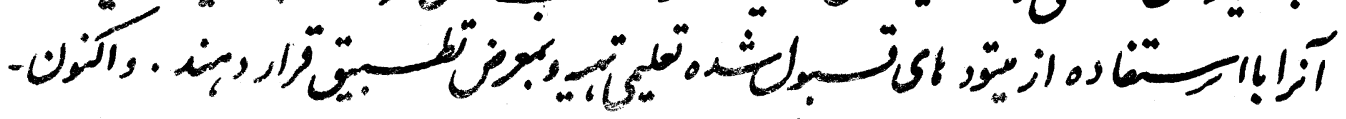

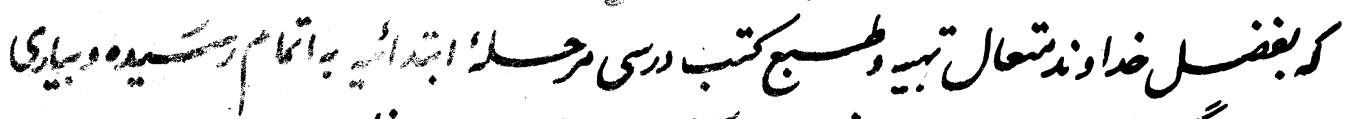

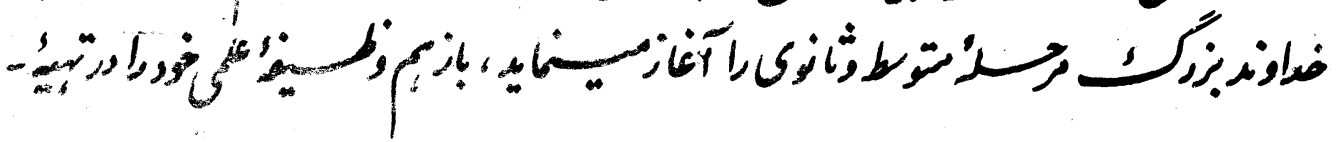
"النــ" 


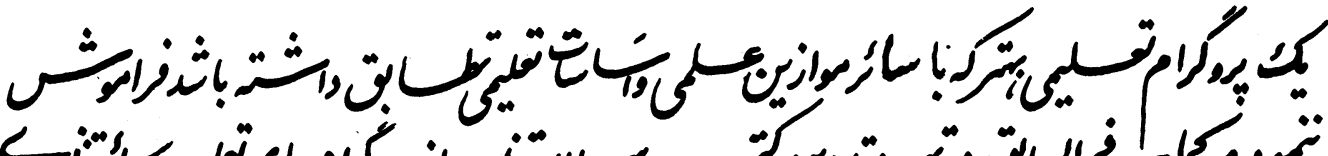

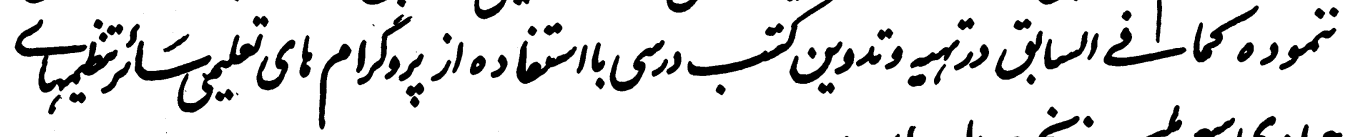

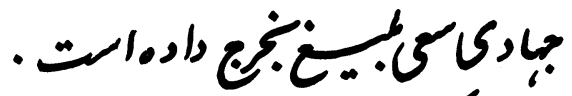

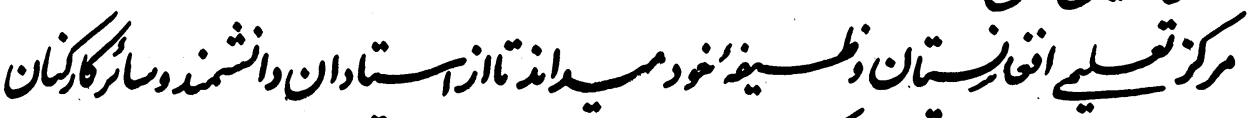

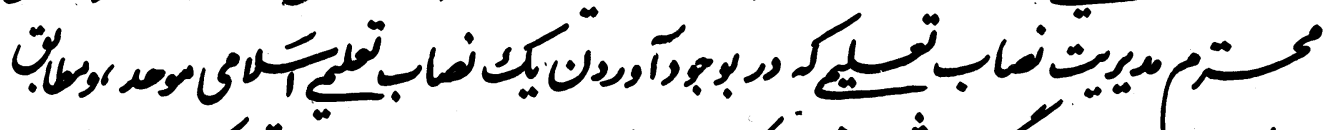

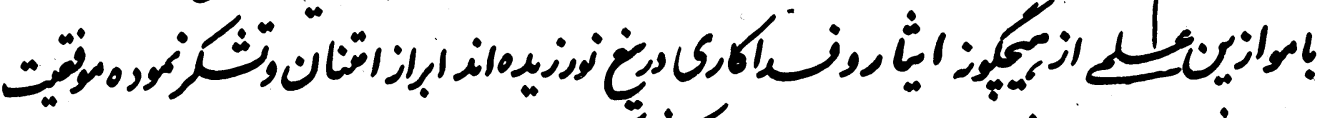

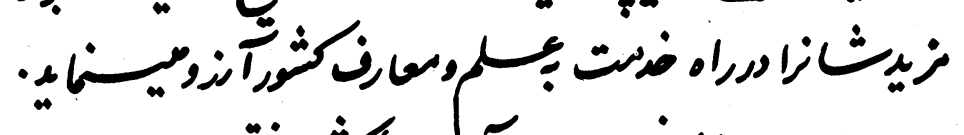

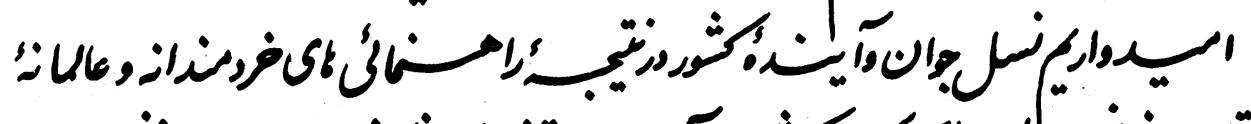

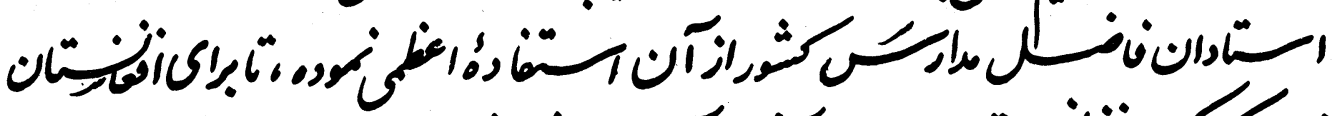

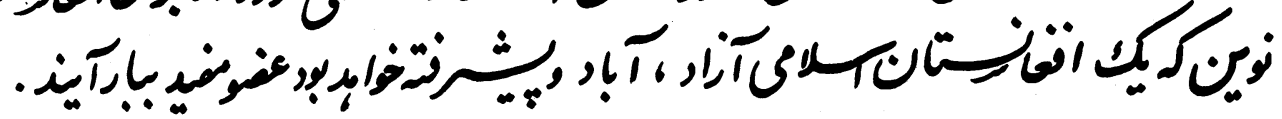

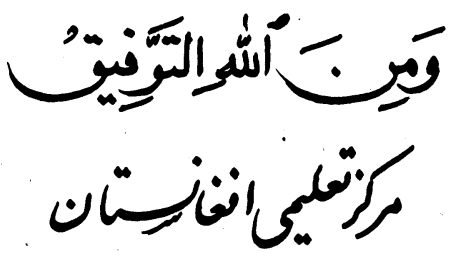



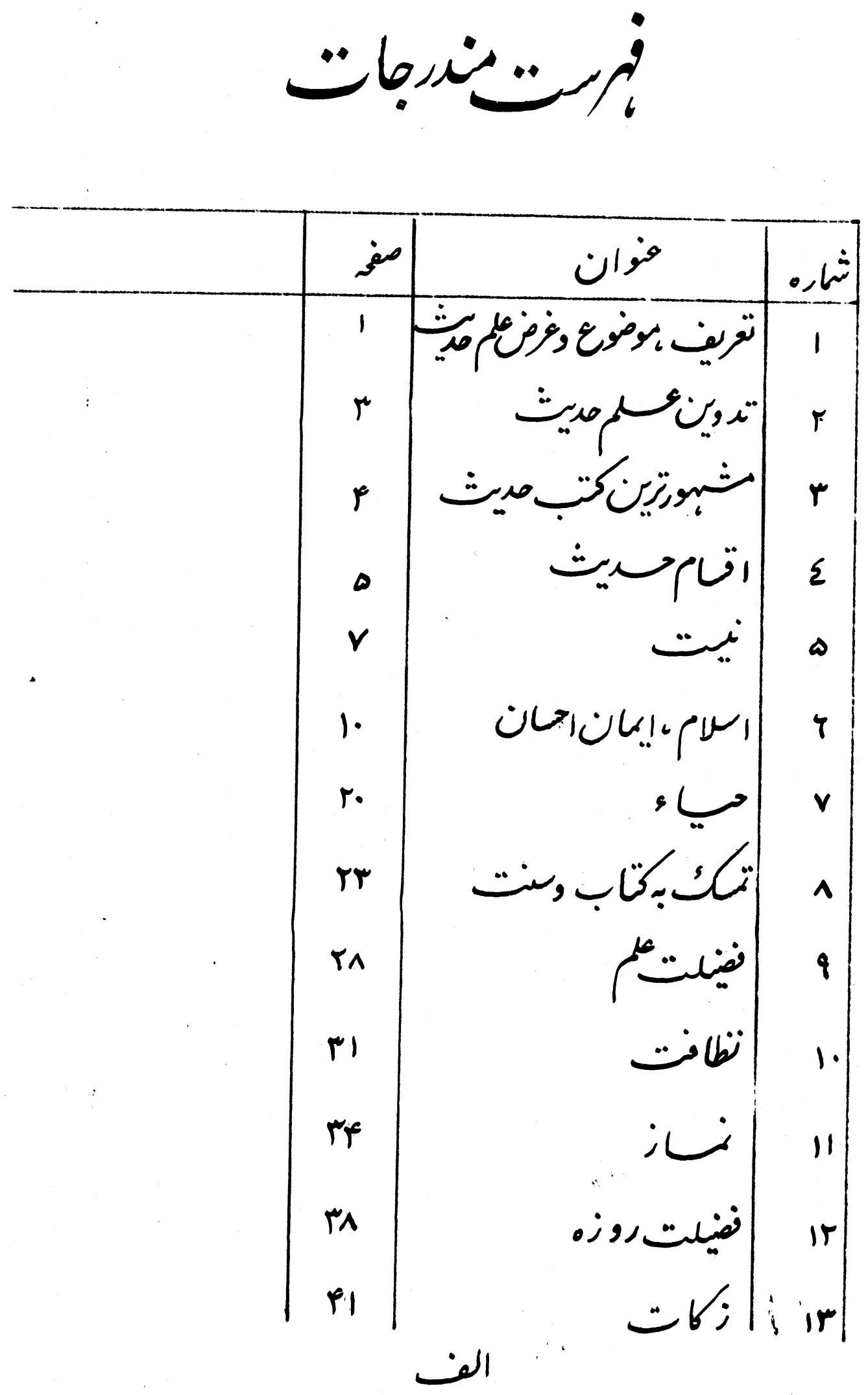


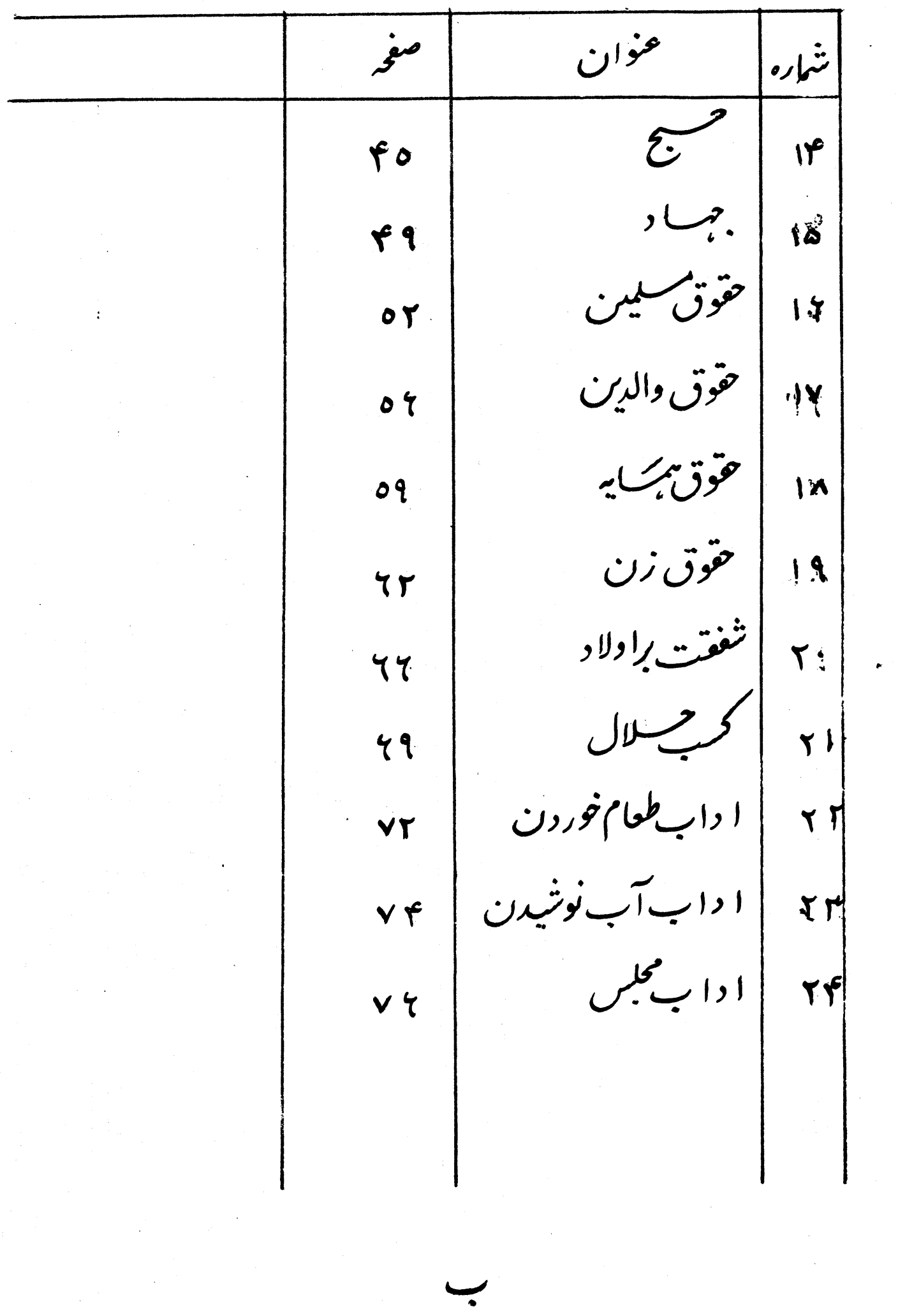




$$
\begin{aligned}
& \text { ابن كتابـ رايكان توزيع مى گرد ددخريدو } \\
& \text { فروشُ !ين كتاب ممنوع ميباشد }
\end{aligned}
$$

سال طبع حمل •IrV تعداد طبع (0... 1) مدئويت نصاب مركز نعليمى 


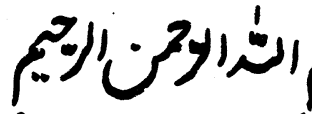

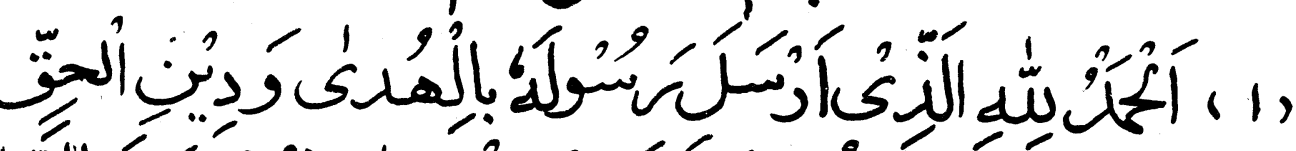

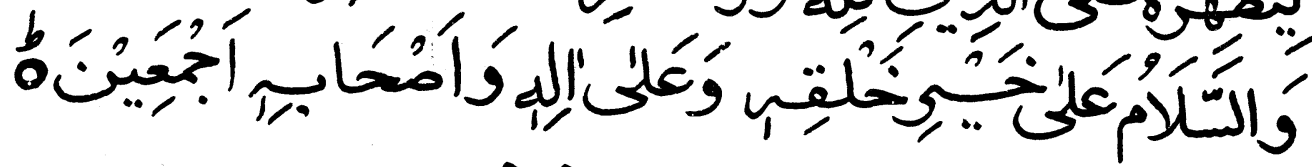

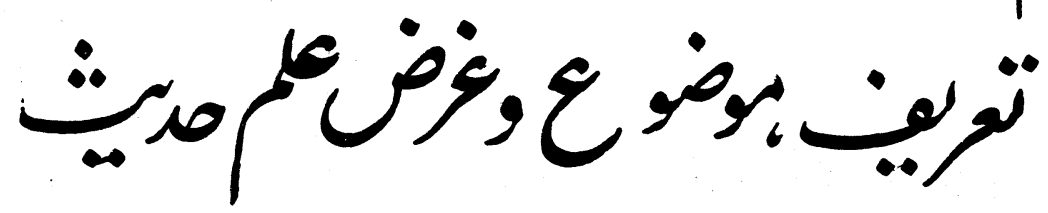

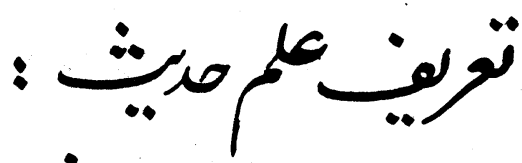

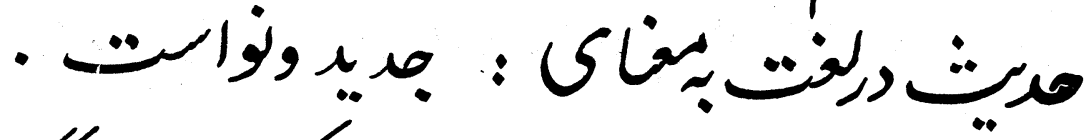

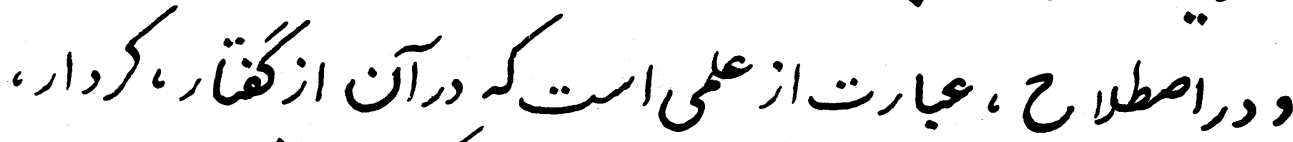

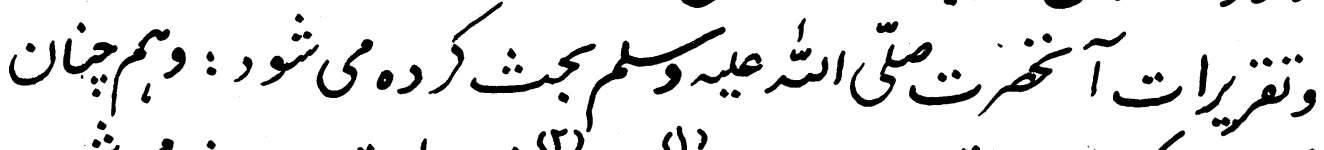

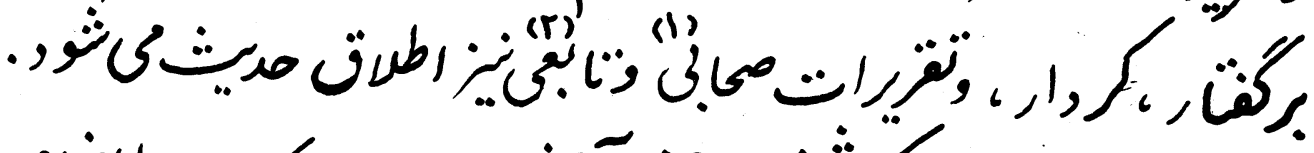

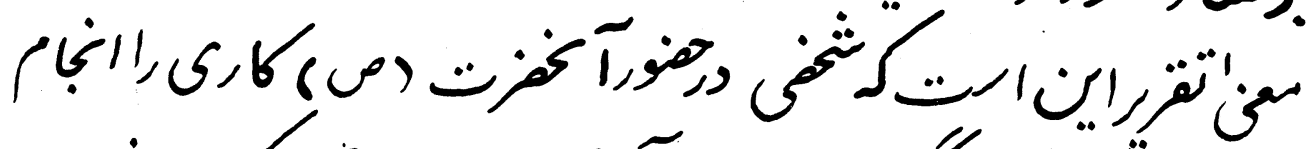

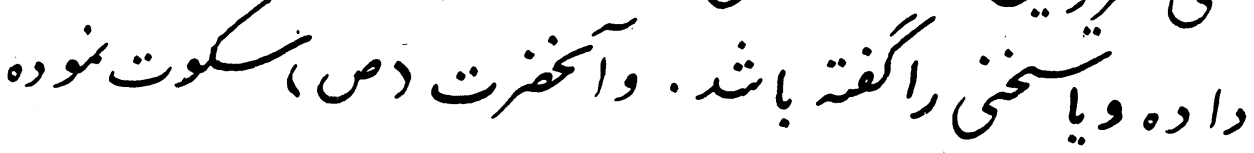

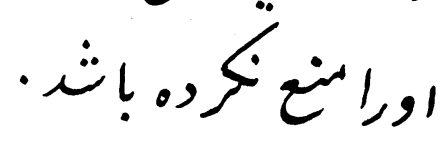

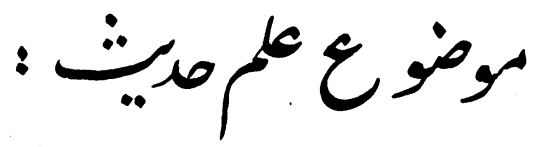

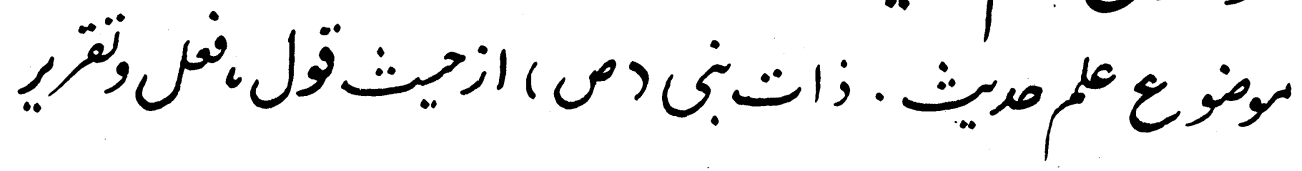

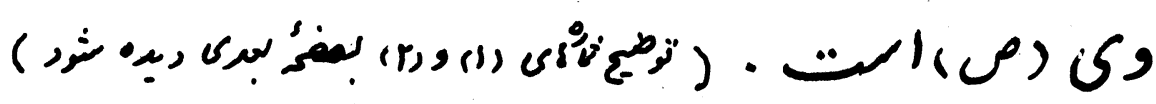




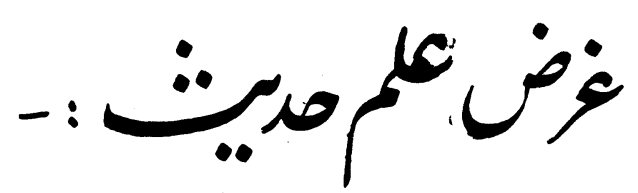

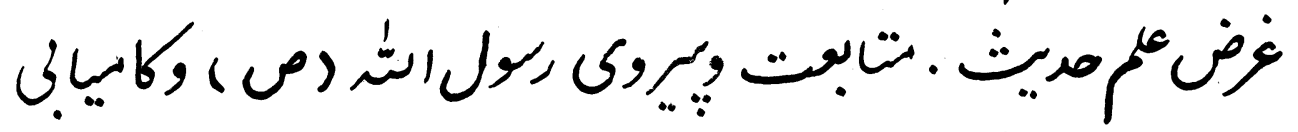

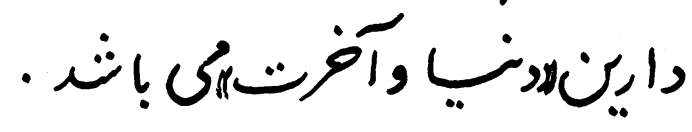

(1)

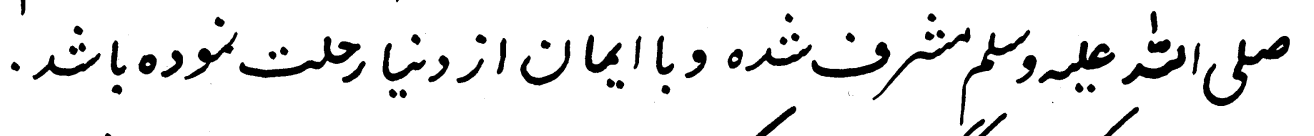

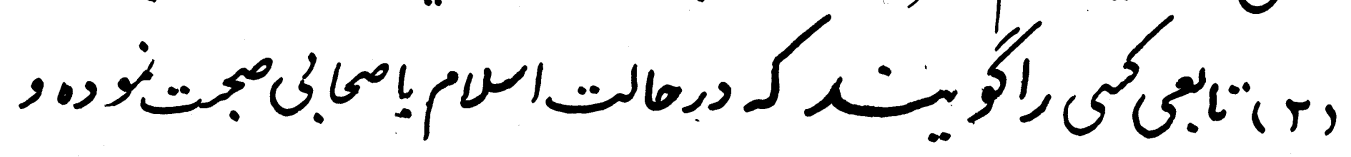

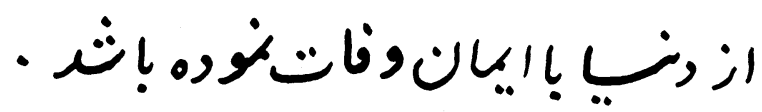

T 


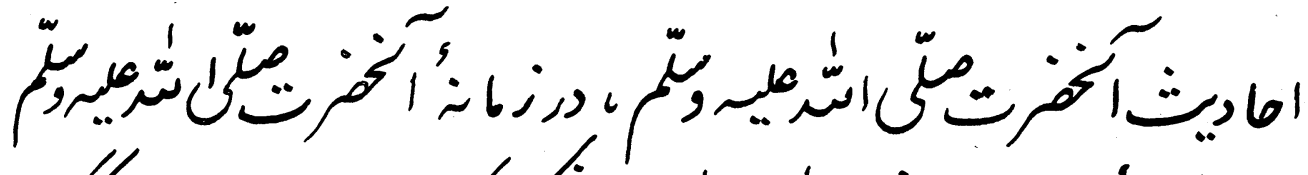

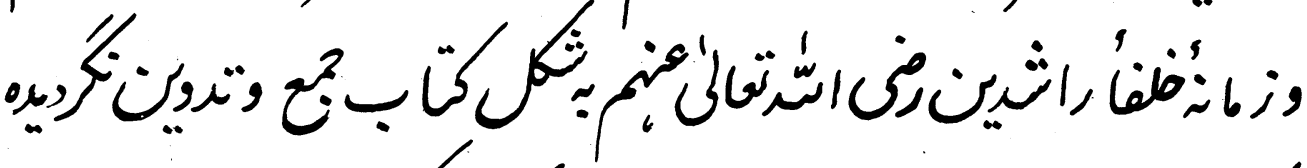

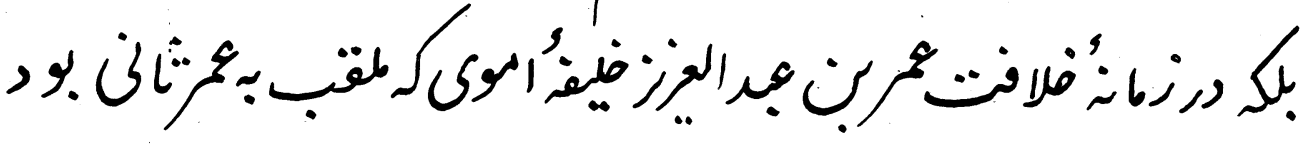

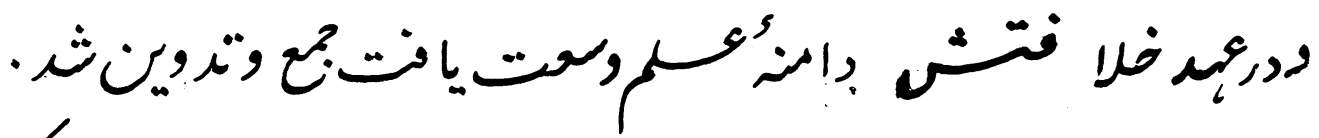

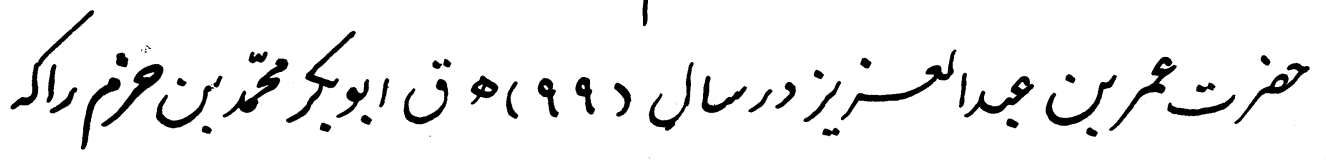

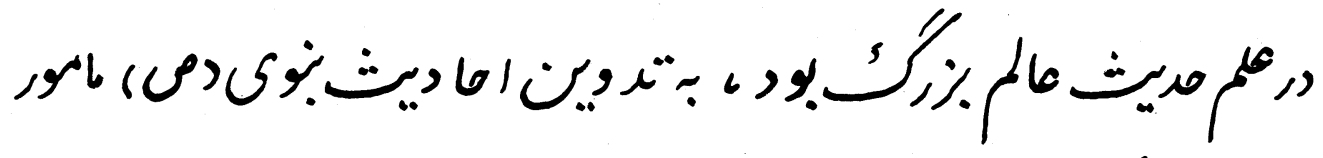

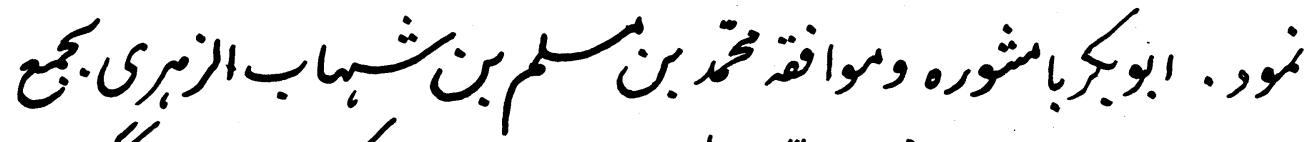

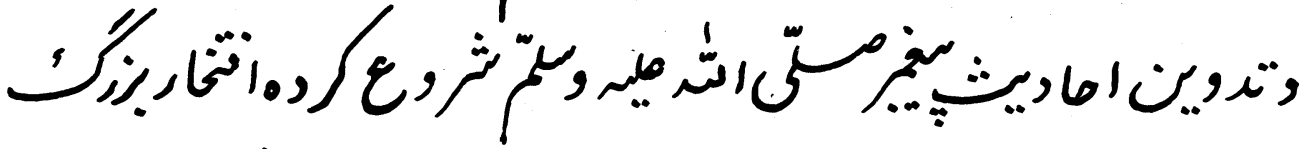

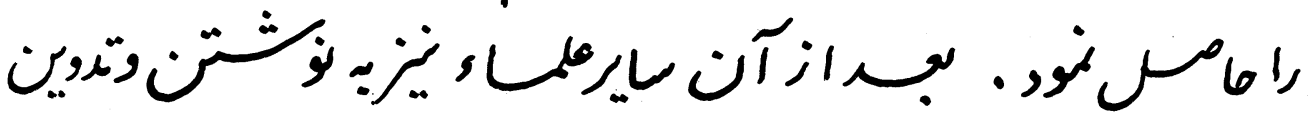

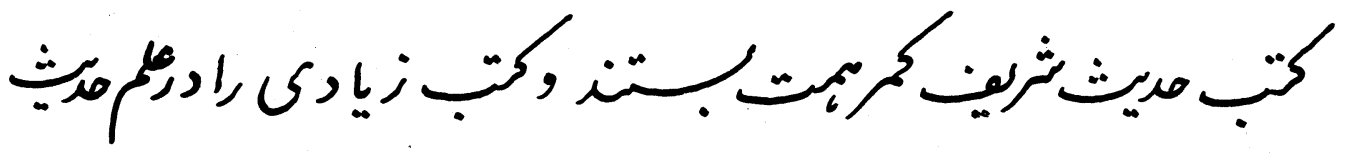
تموين وتينتنورنر. 


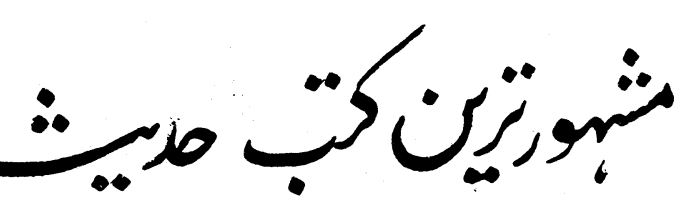

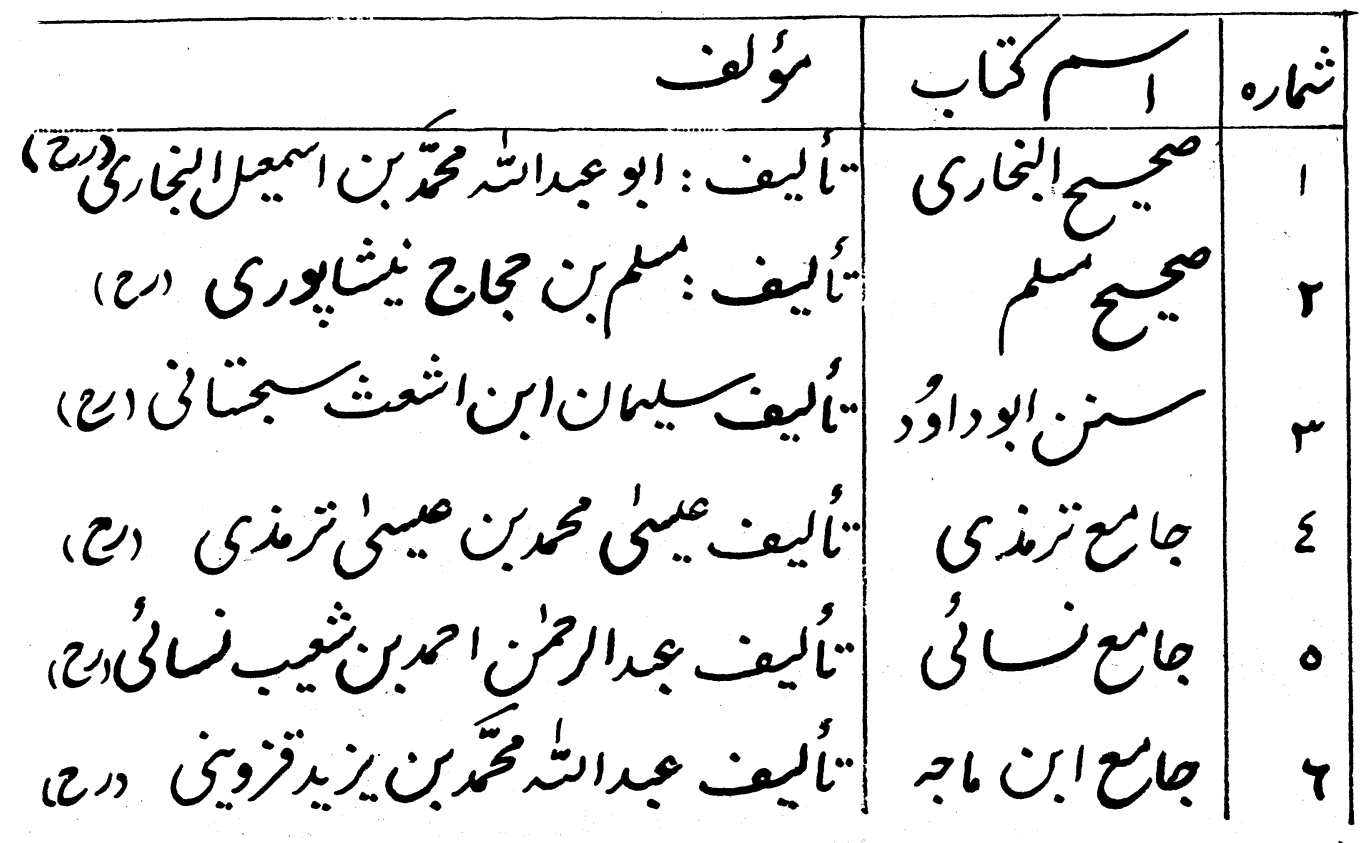

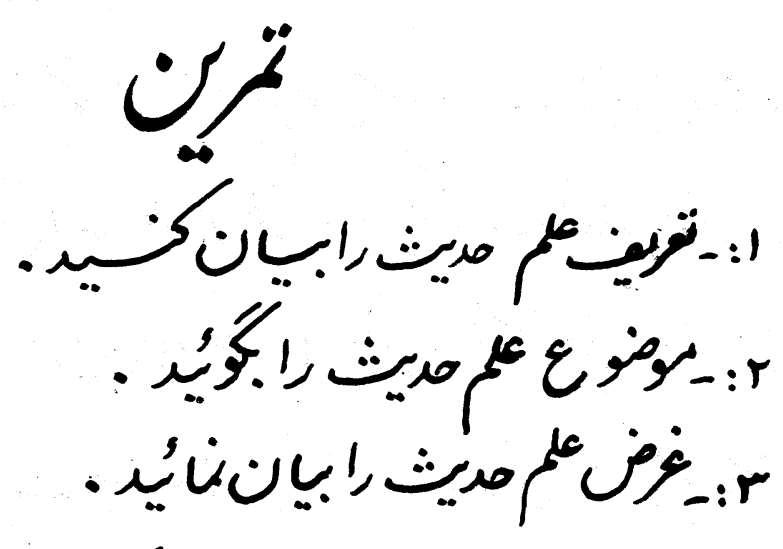

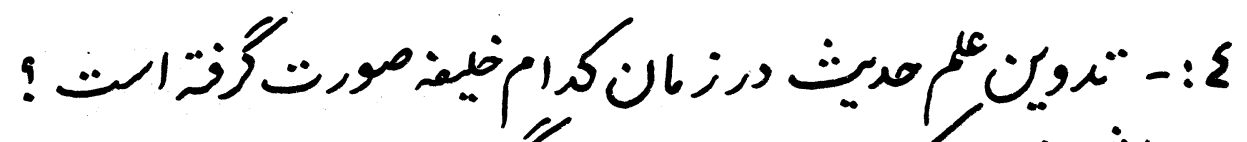

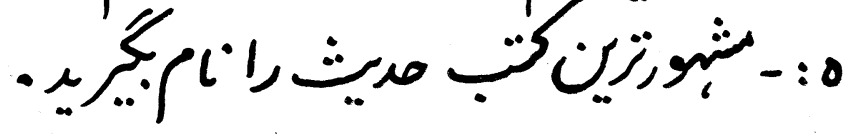




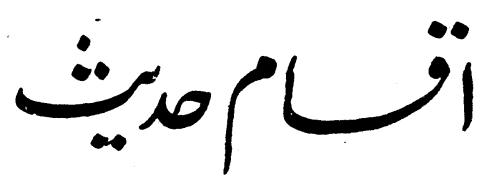

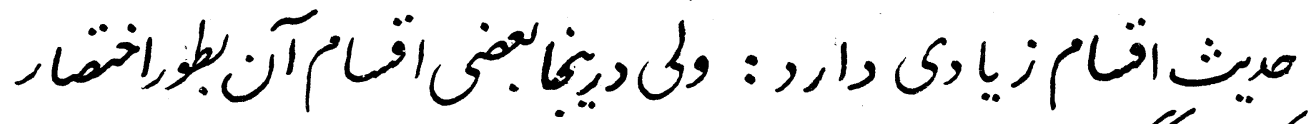

$$
\begin{aligned}
& \text {;كى كر,: }
\end{aligned}
$$

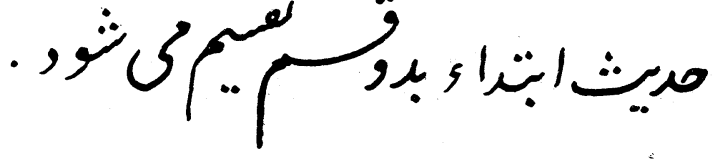

$$
\begin{aligned}
& \text { أه-جمرتواتز }
\end{aligned}
$$

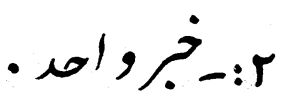

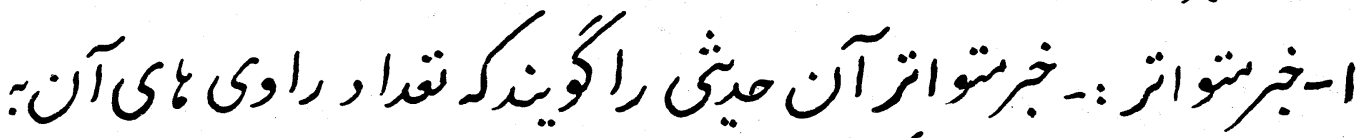

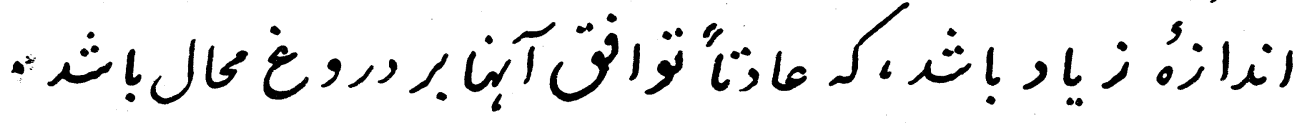

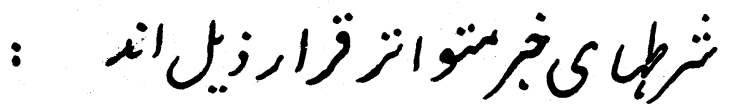

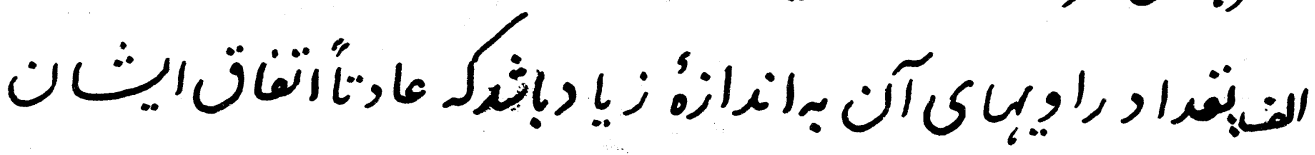

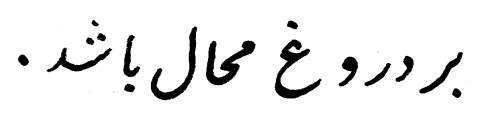

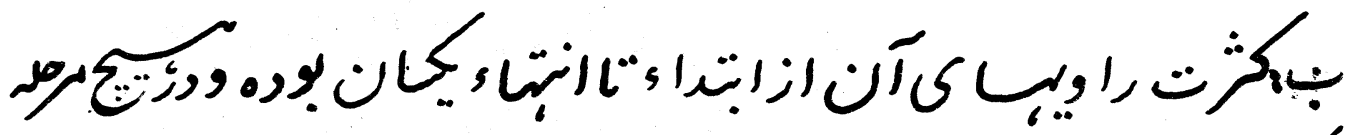

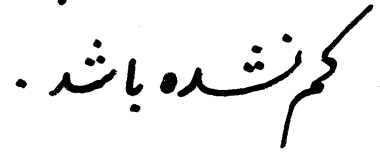

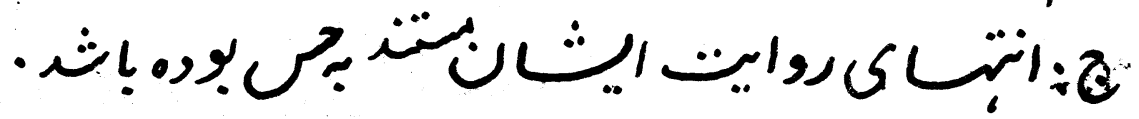

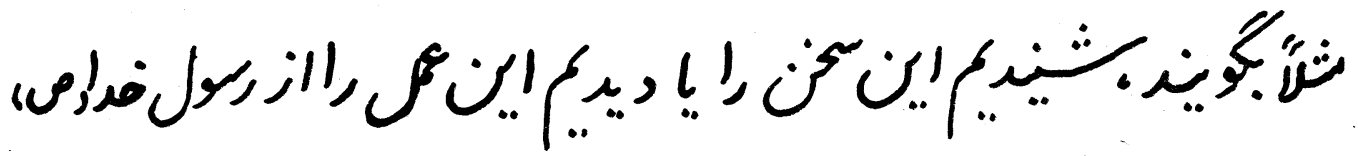




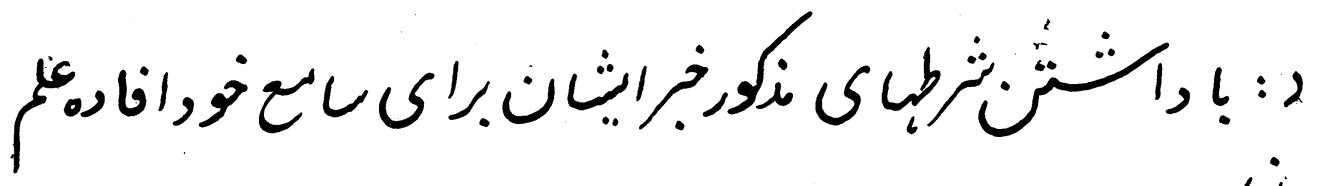

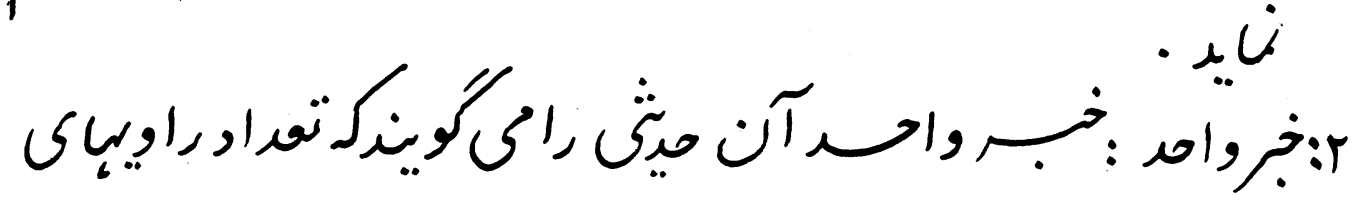

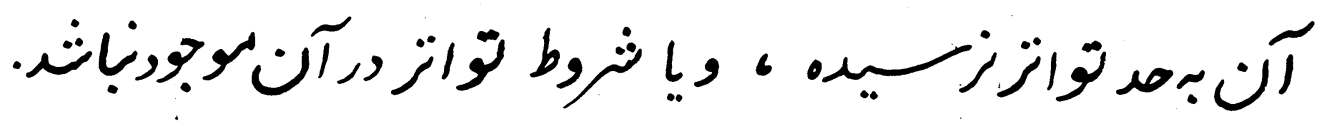

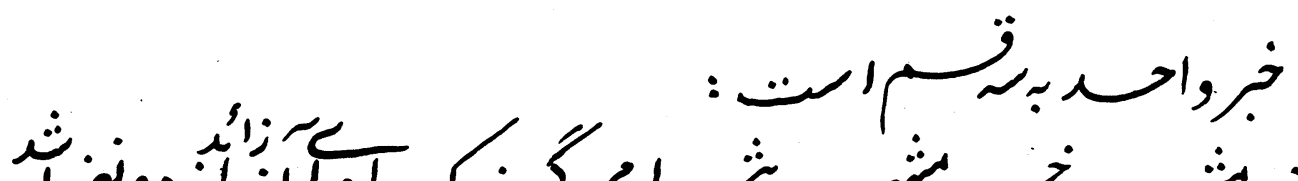

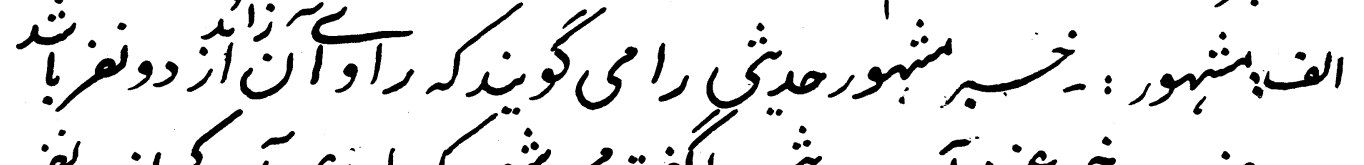

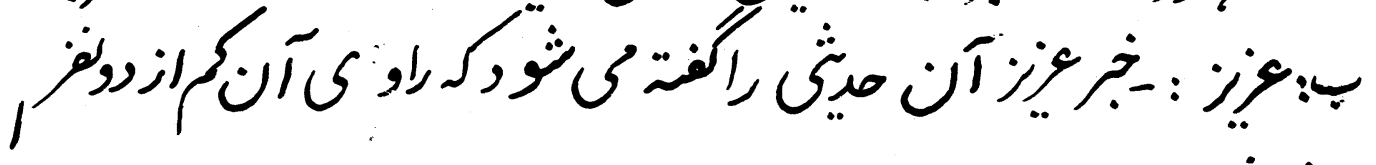
- ن

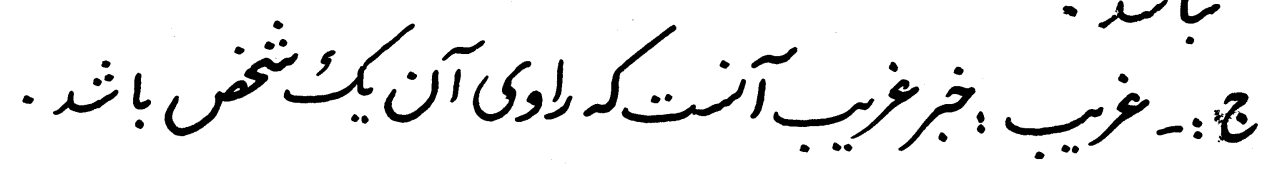

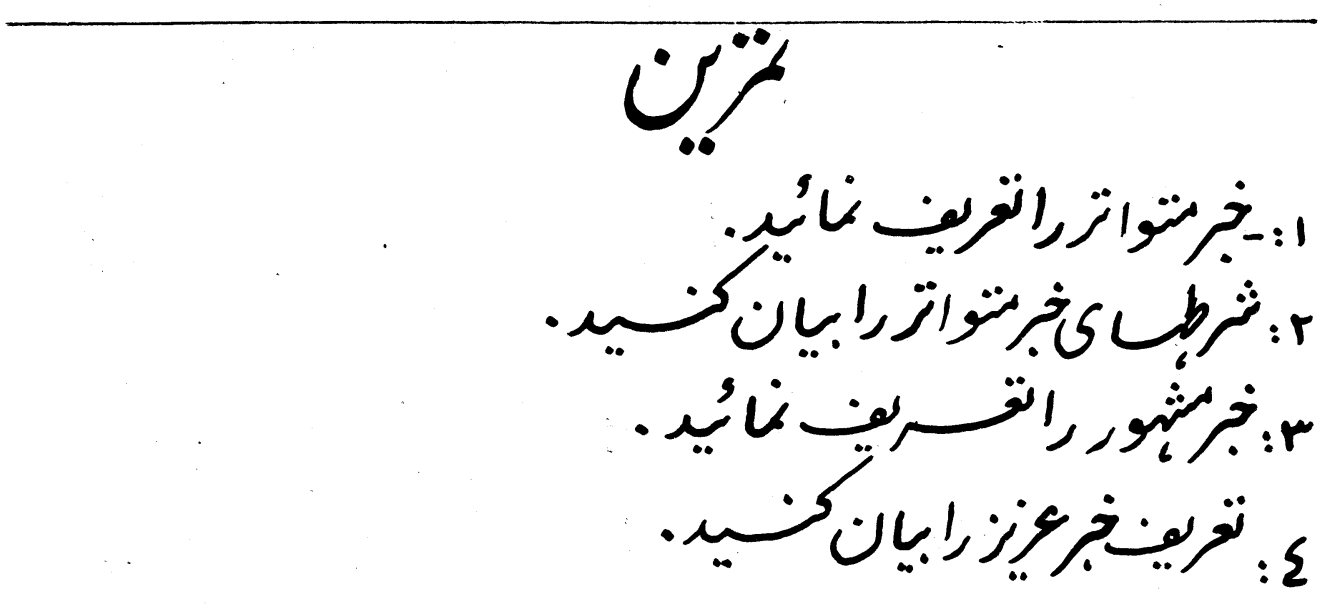


تمبت

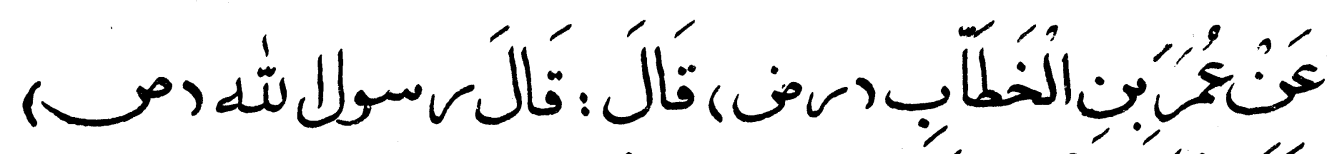

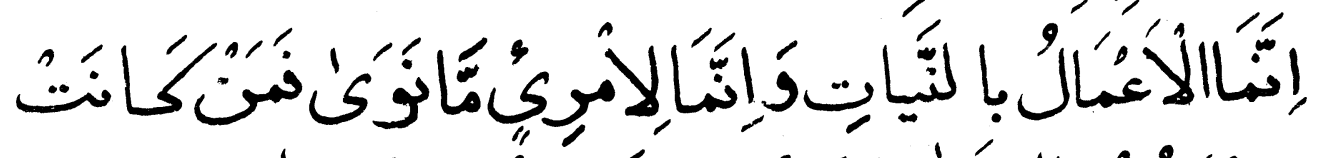

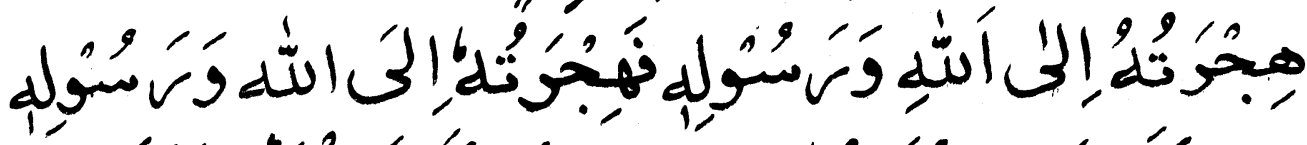

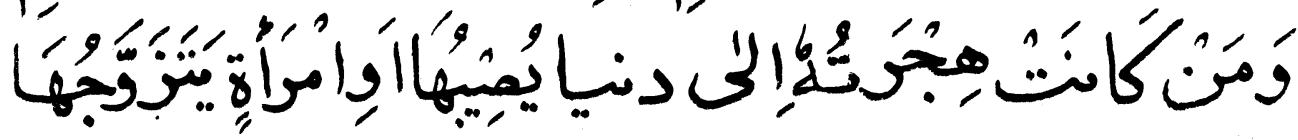

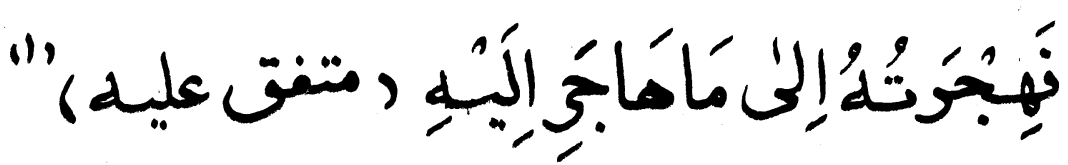

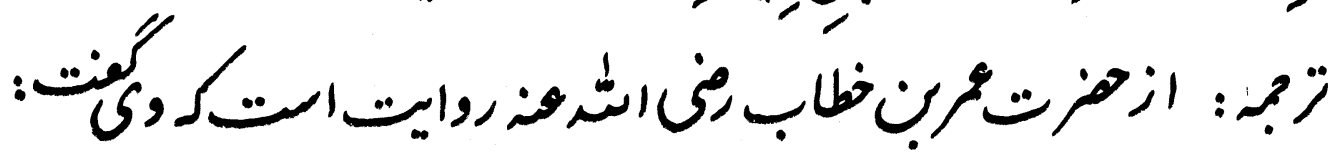

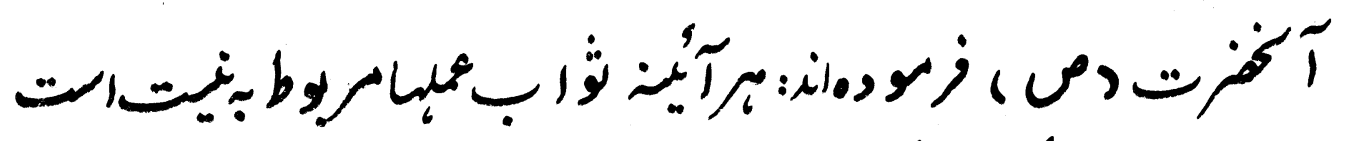

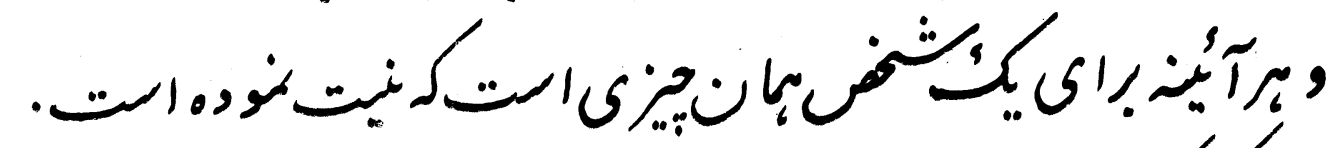

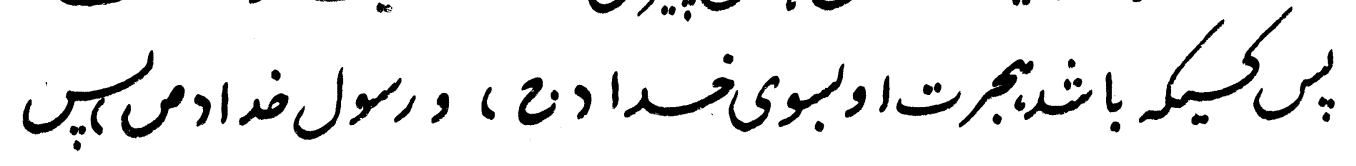

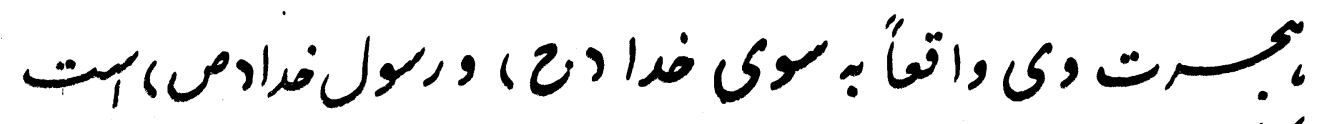

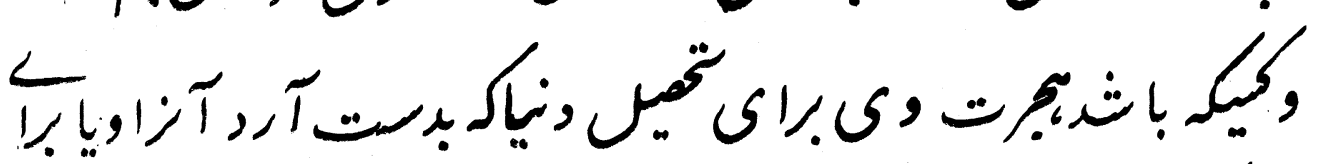

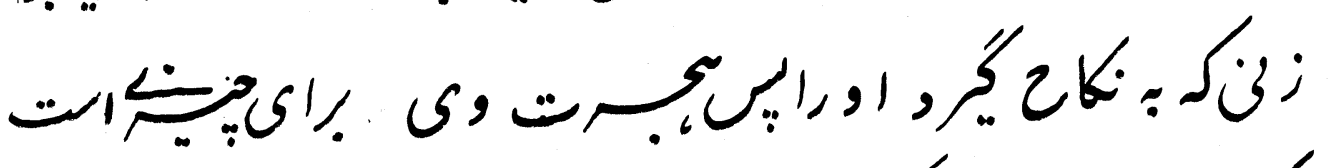

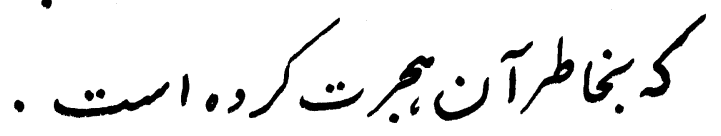

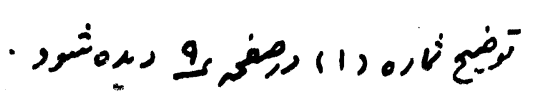

$\checkmark$ 


\section{ثز حمبث}

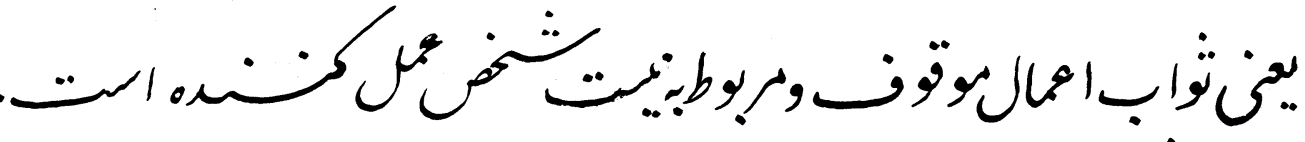

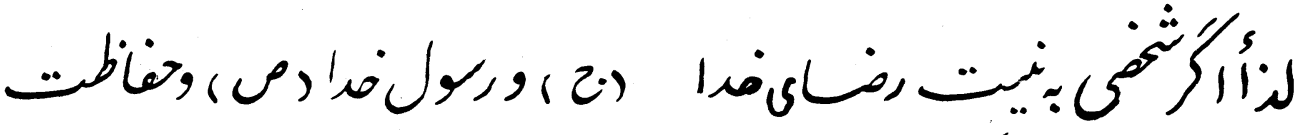

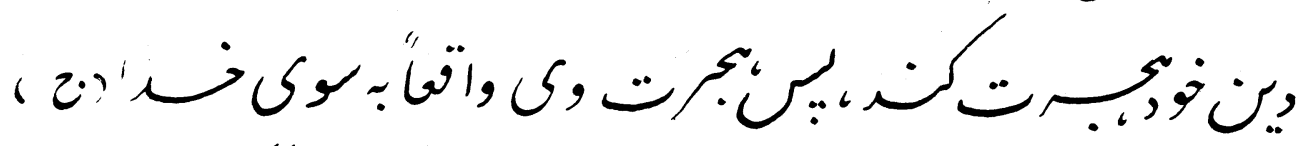

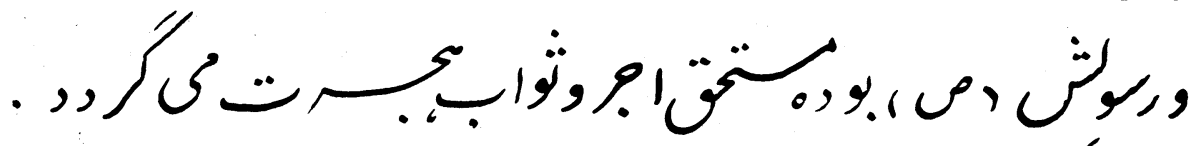

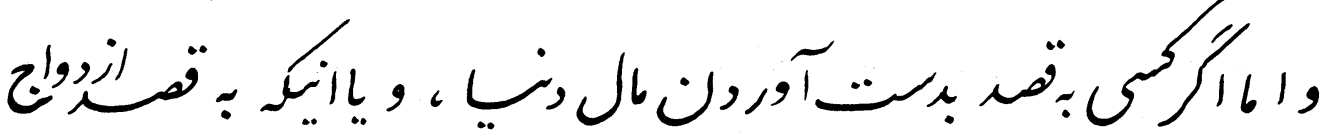

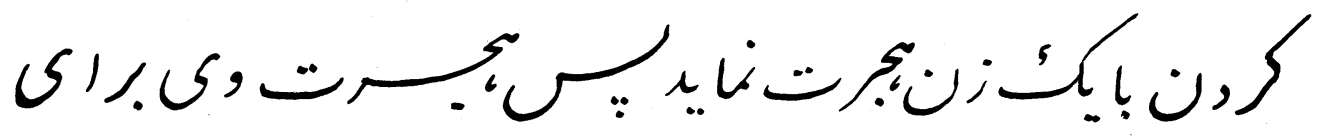

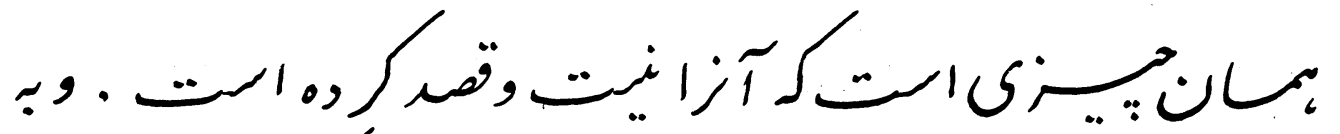

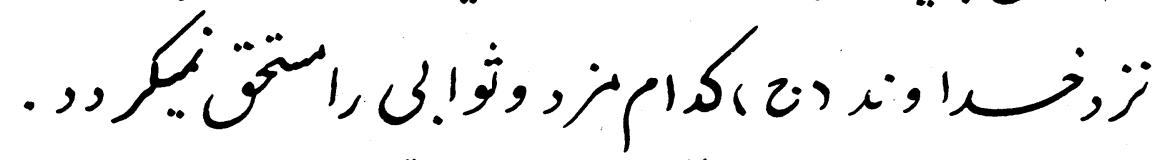

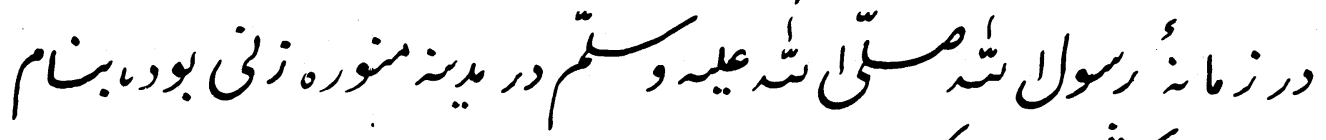

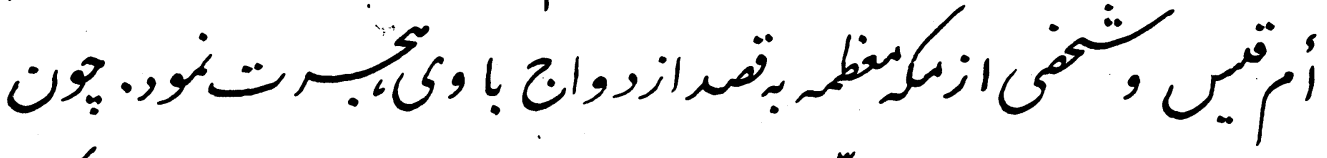

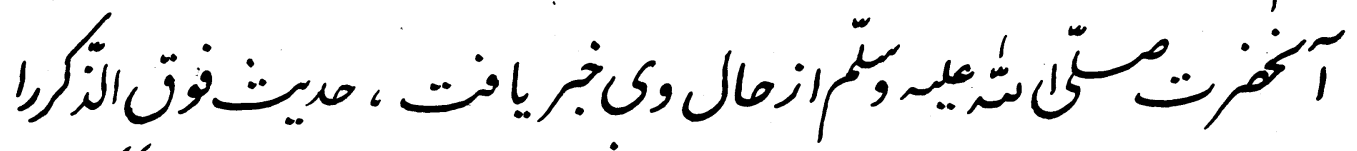

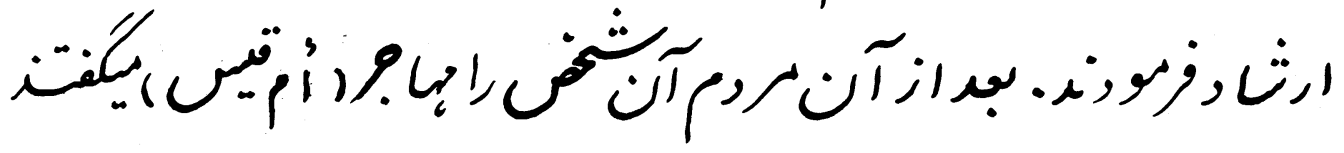




$$
\begin{aligned}
& \rightarrow 5
\end{aligned}
$$

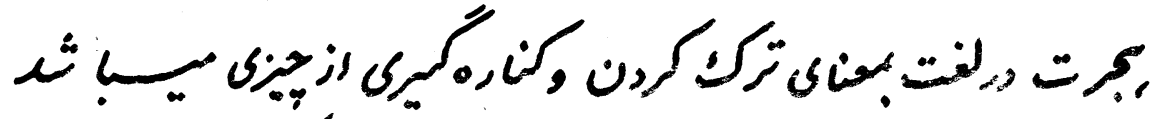

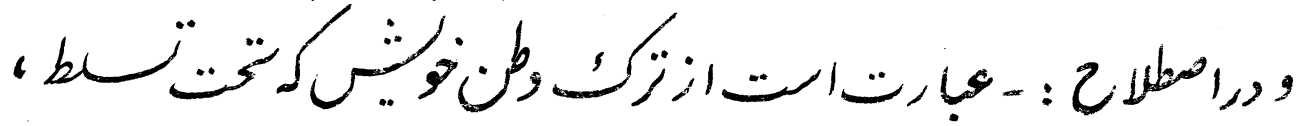

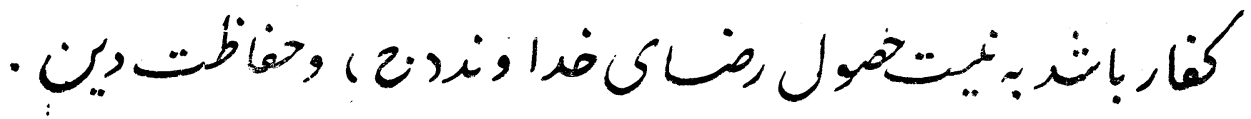

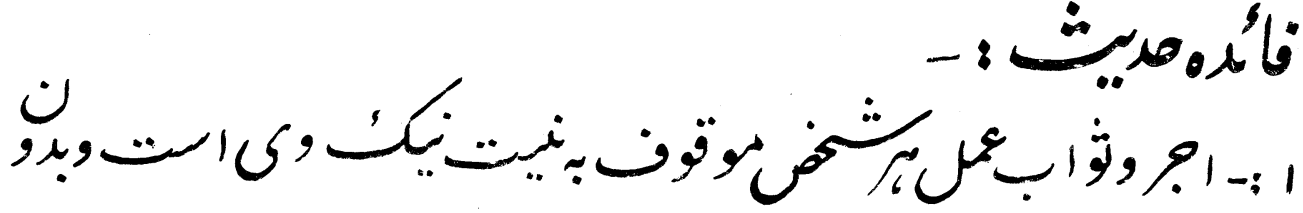

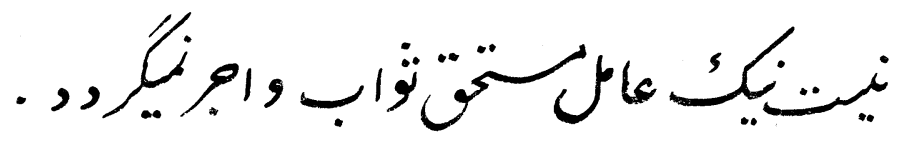

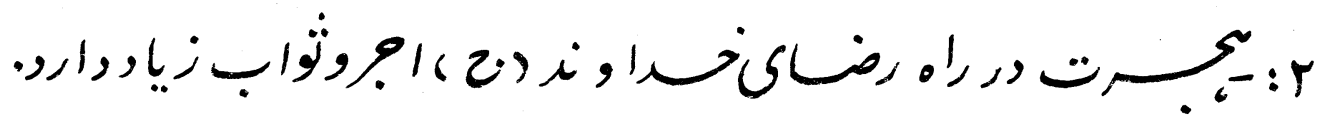

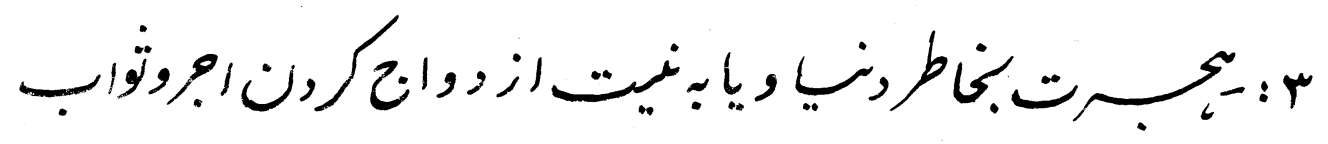

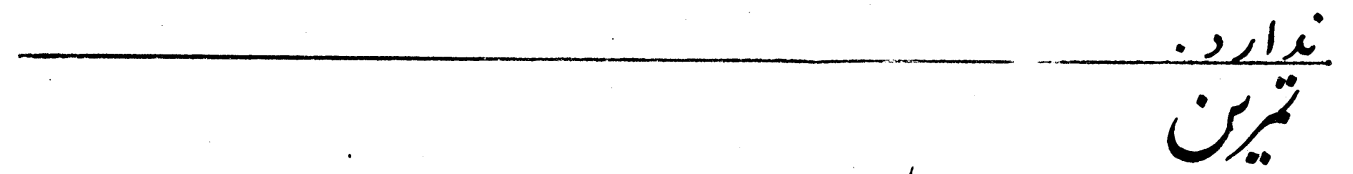

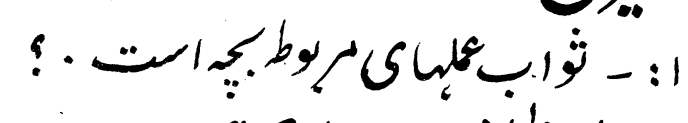

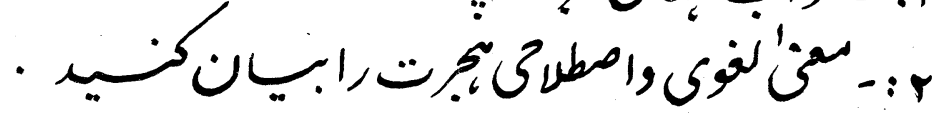

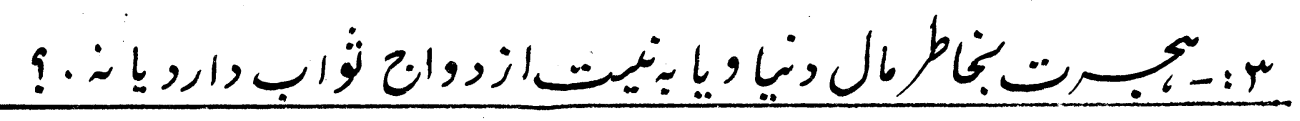

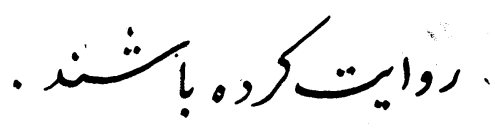




\section{اسلام،ايــان،ان}

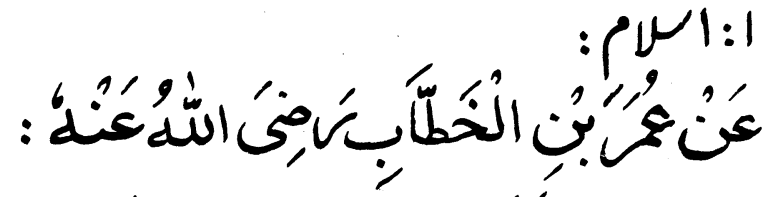

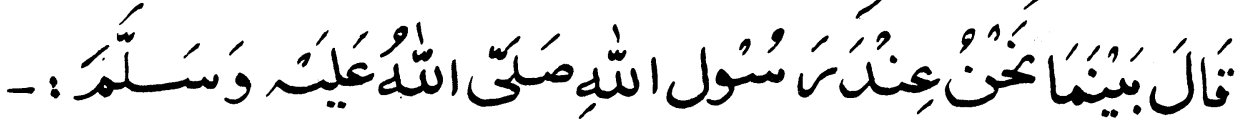

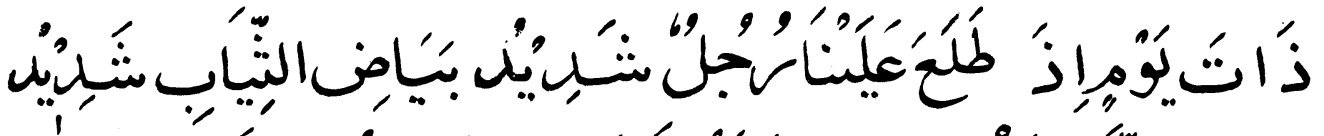

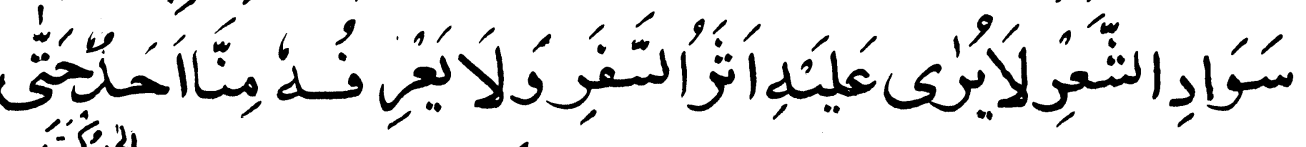

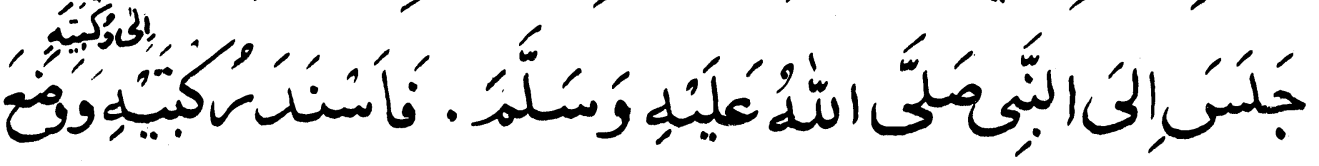

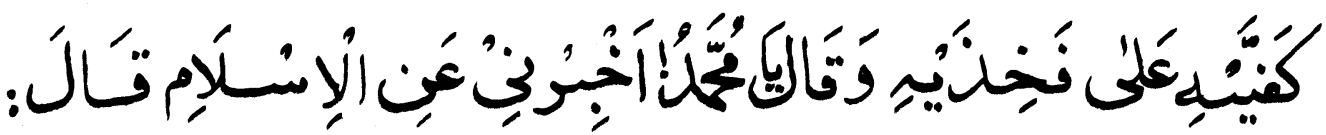

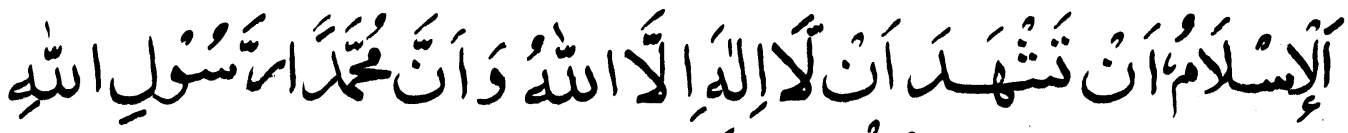

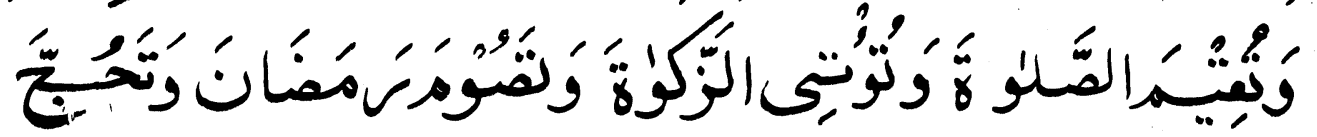

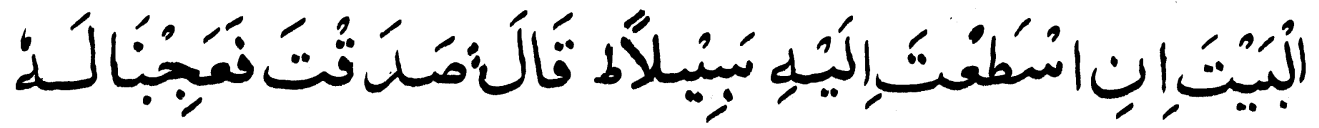

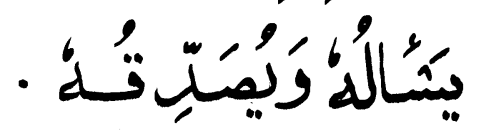

$$
\text { تקים : - וקי }
$$

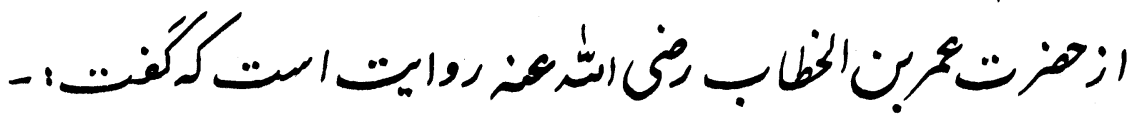

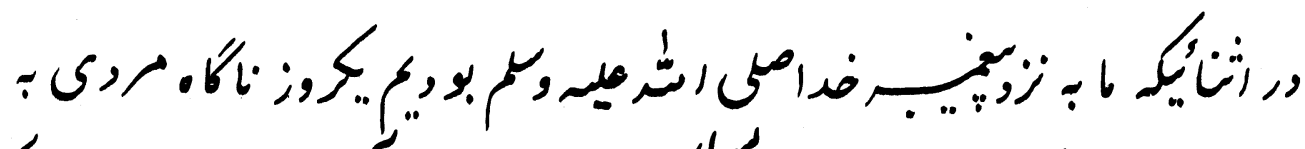

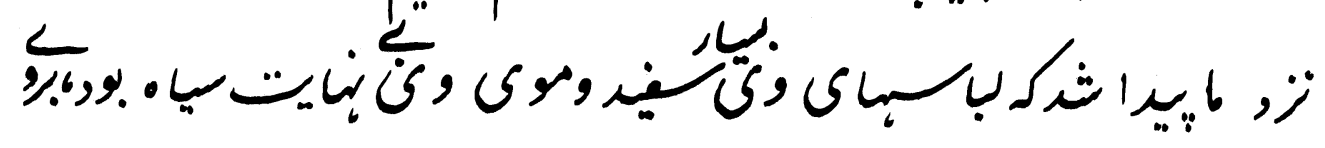




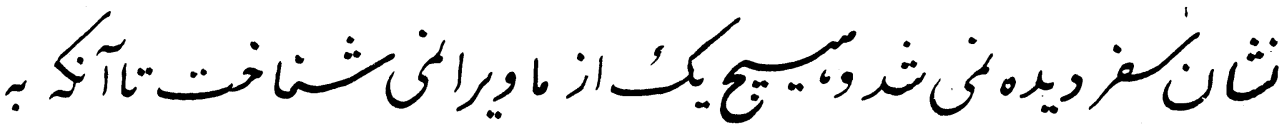

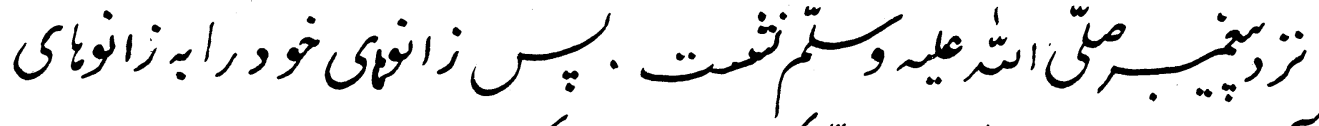

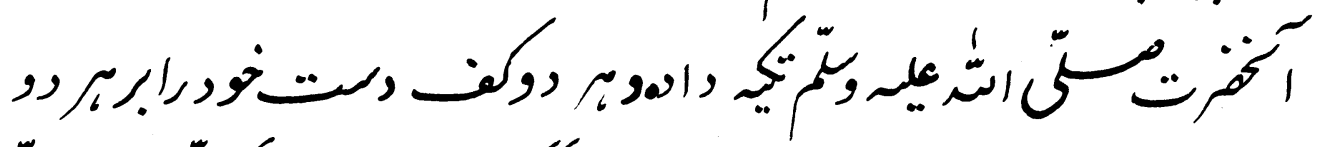

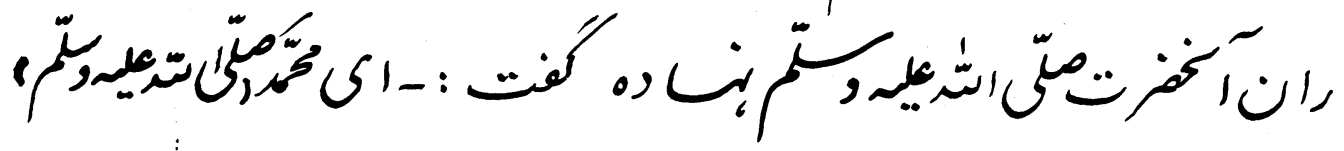

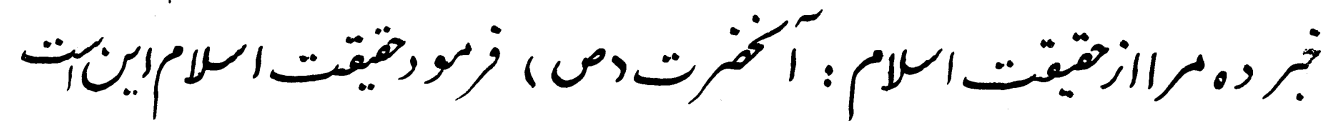

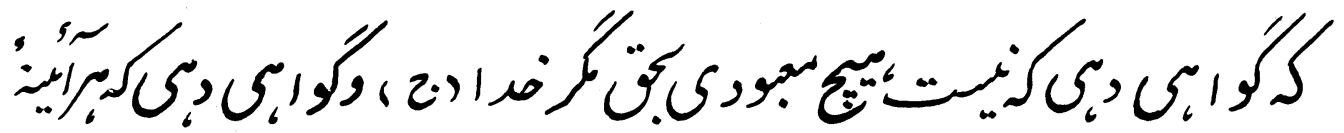

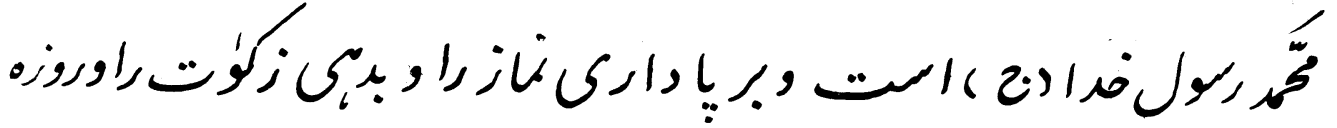

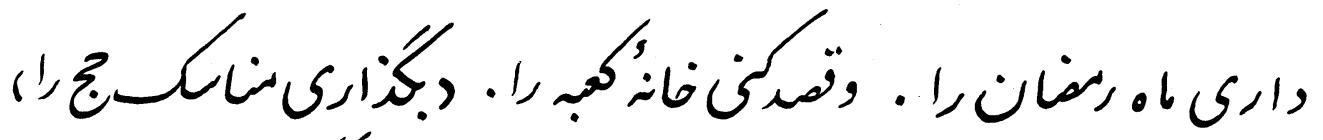

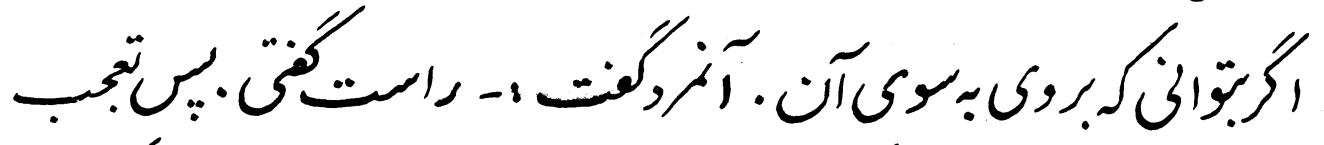

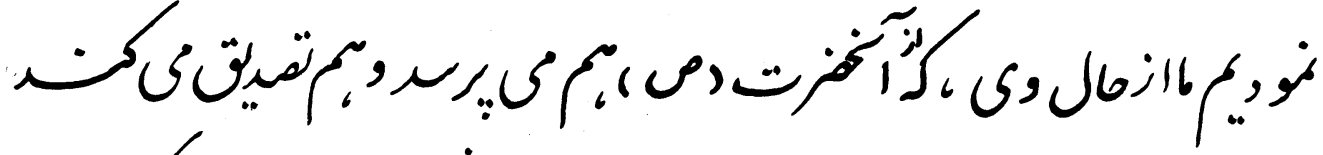

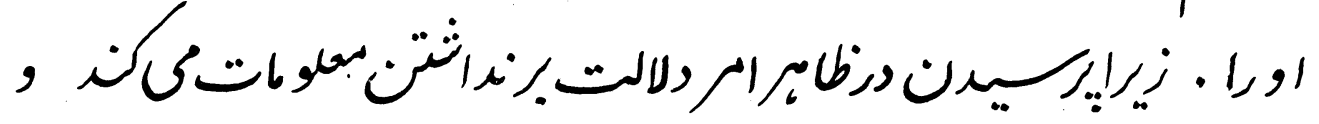

$$
\text { تصين ولالت.رعم. }
$$

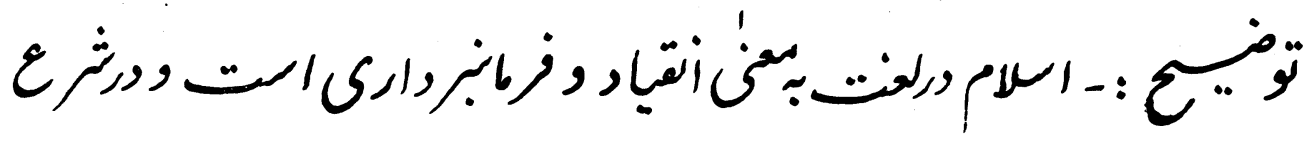

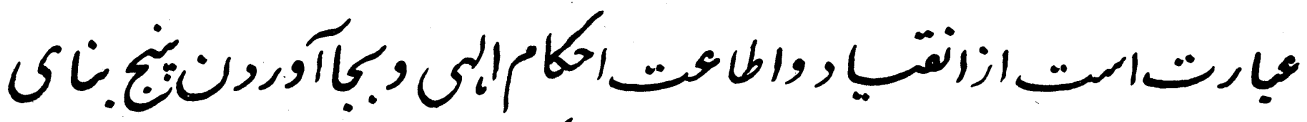

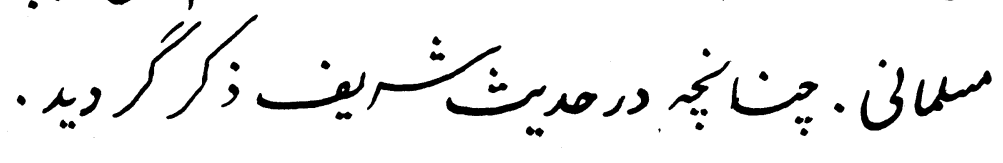




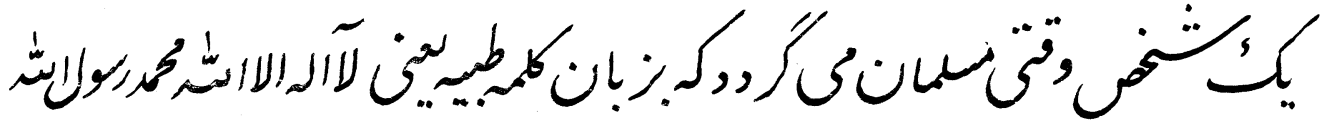

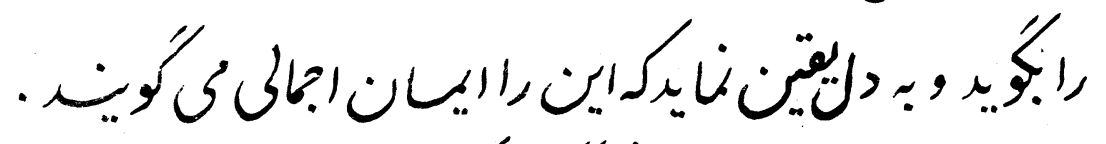

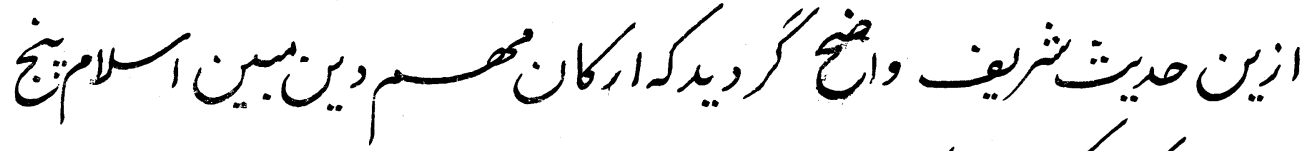

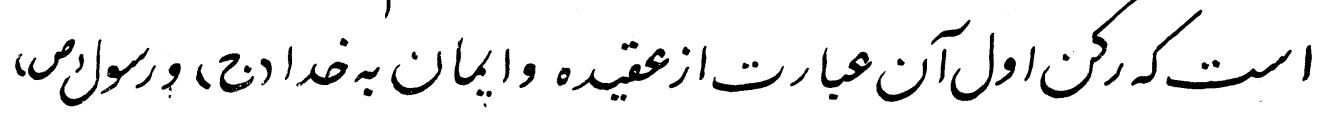

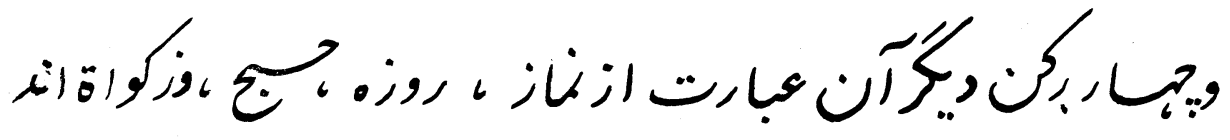

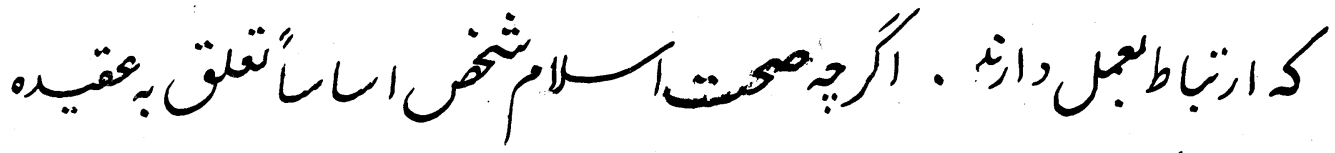

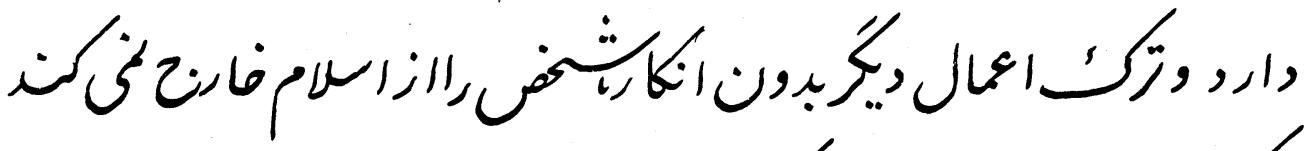

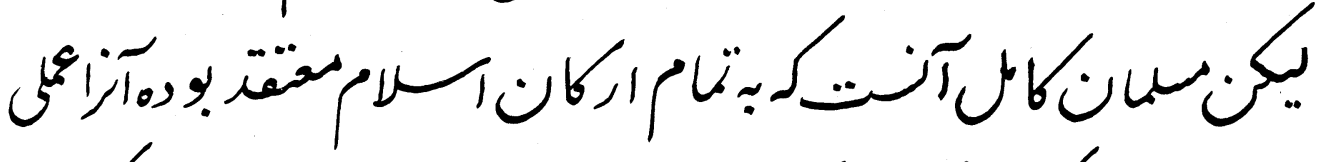

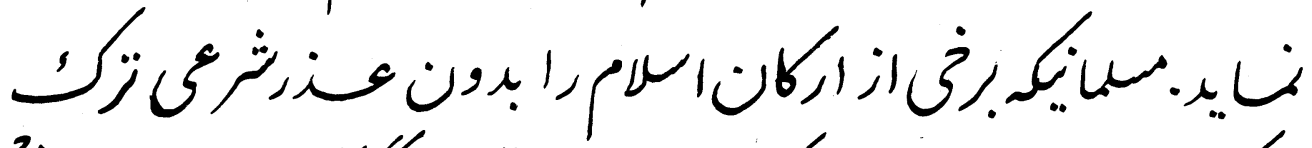

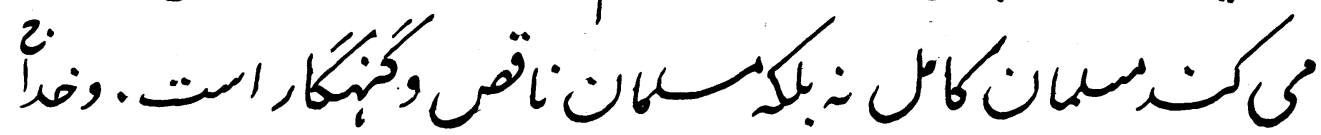

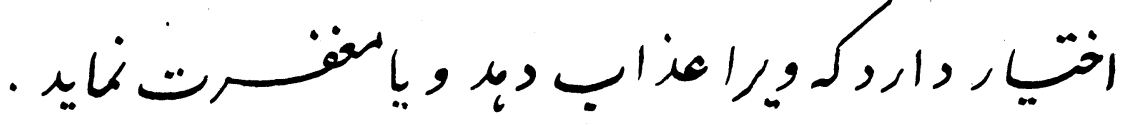

$$
\begin{aligned}
& \text { فأحس }
\end{aligned}
$$




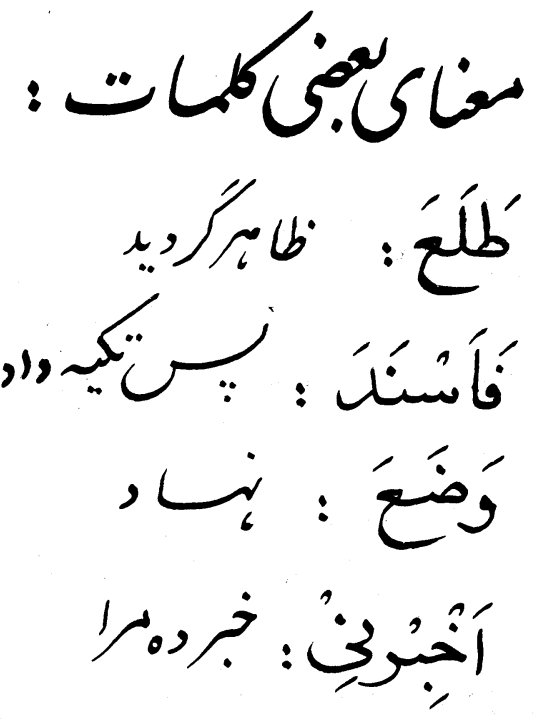




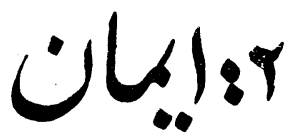

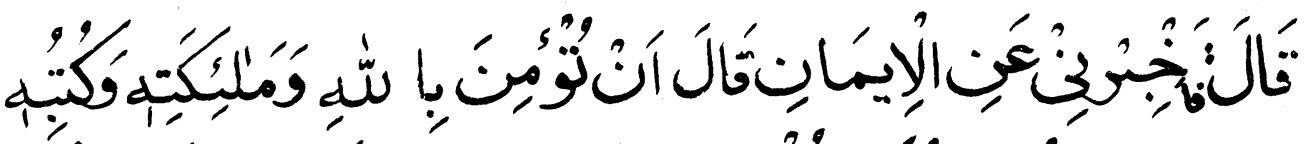

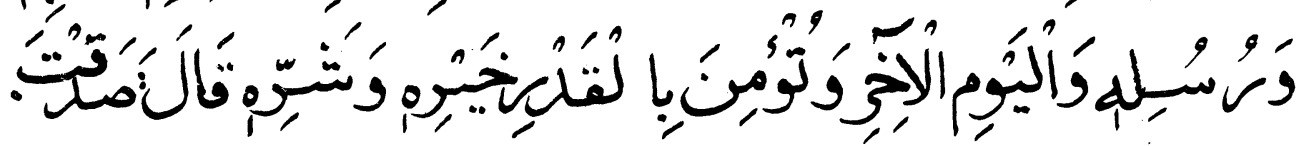

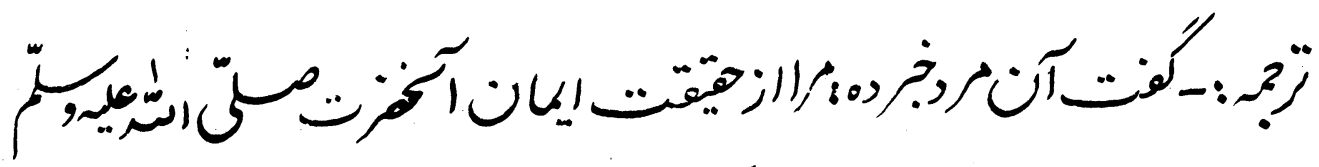

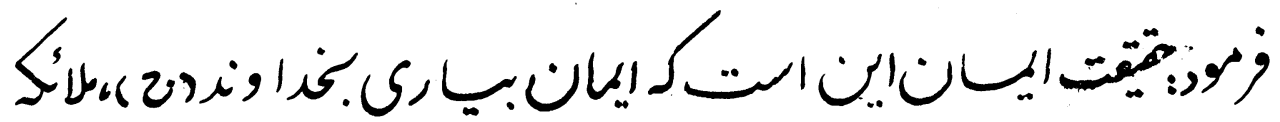

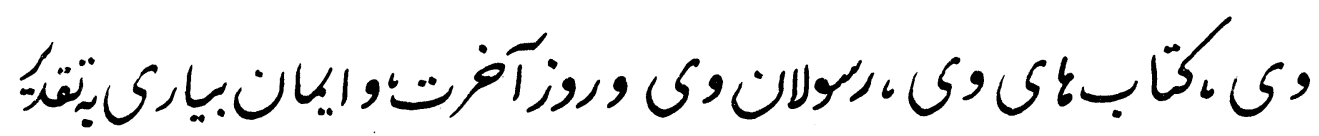

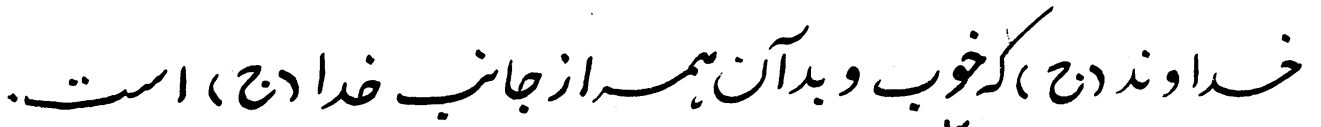

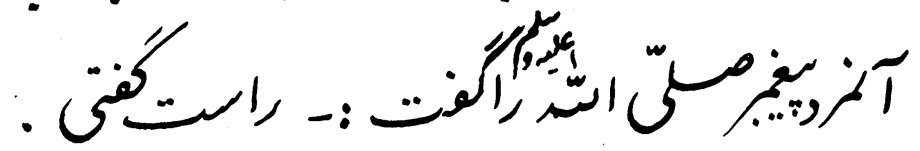

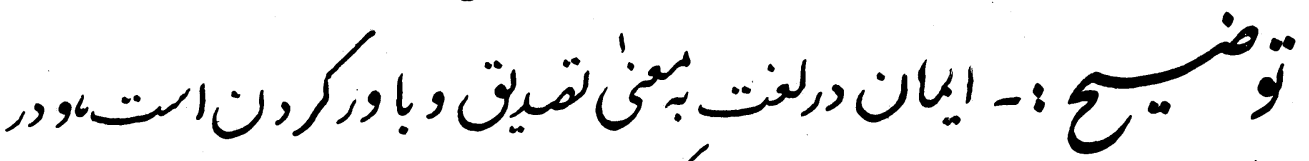

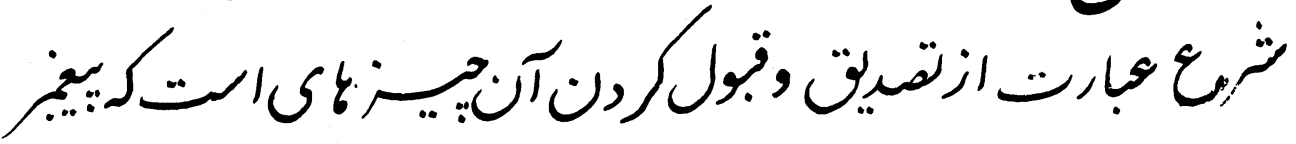

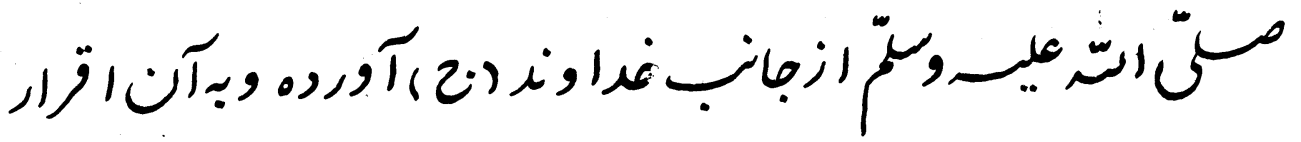

-

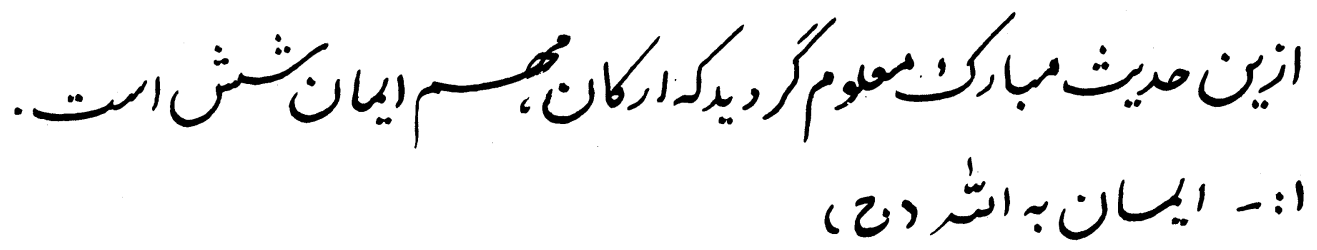




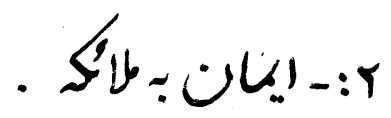

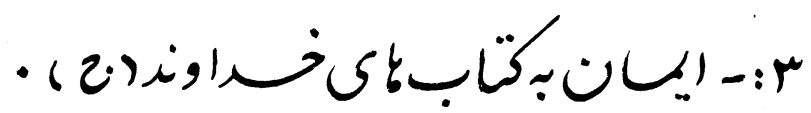

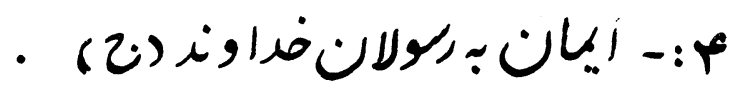

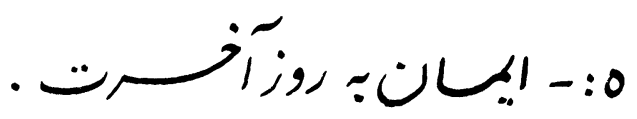

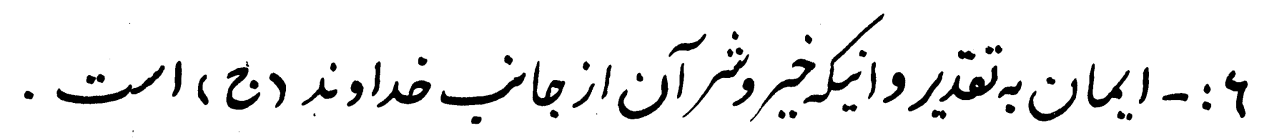

- :

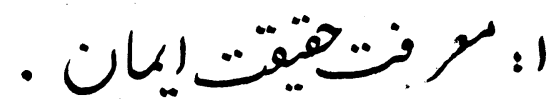

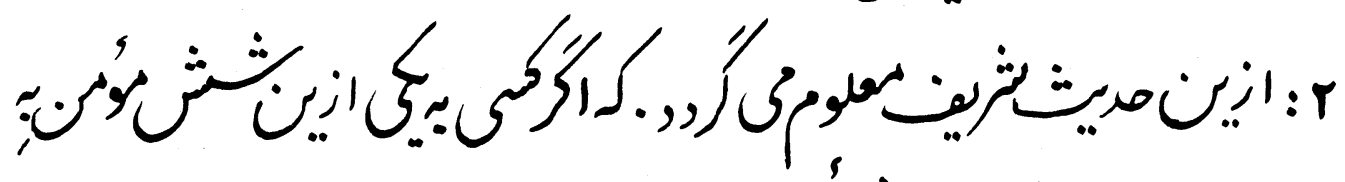

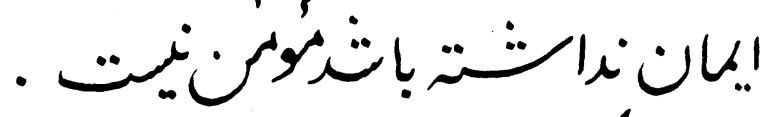

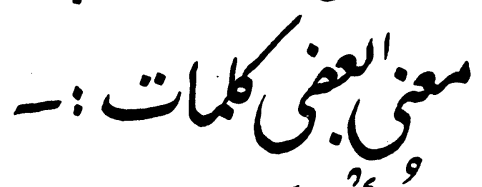

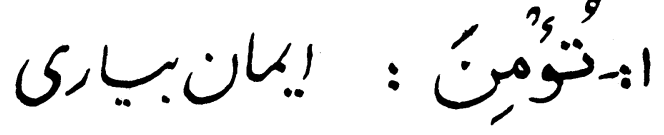

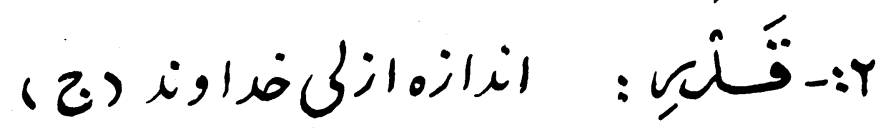

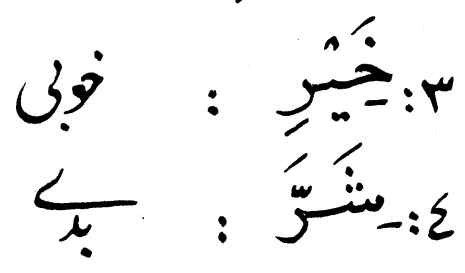

10 


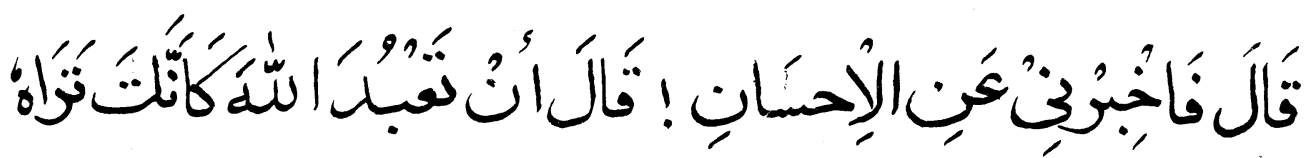

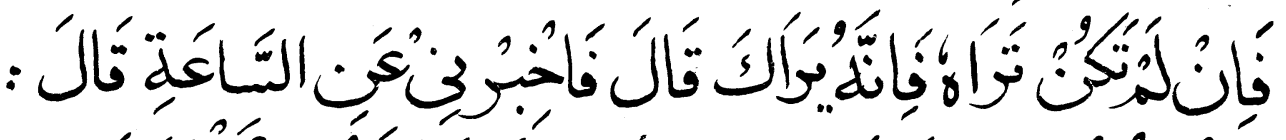

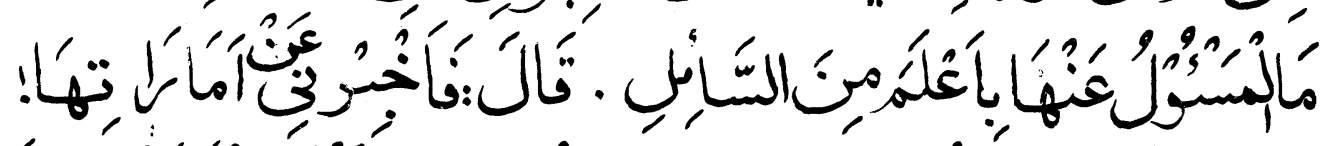

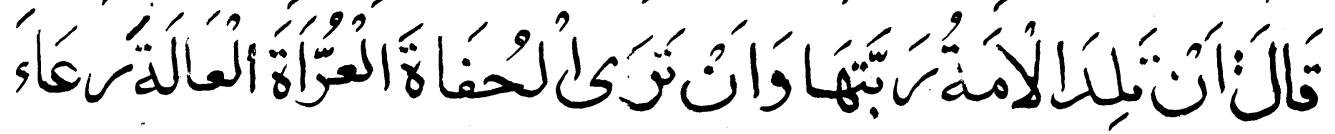

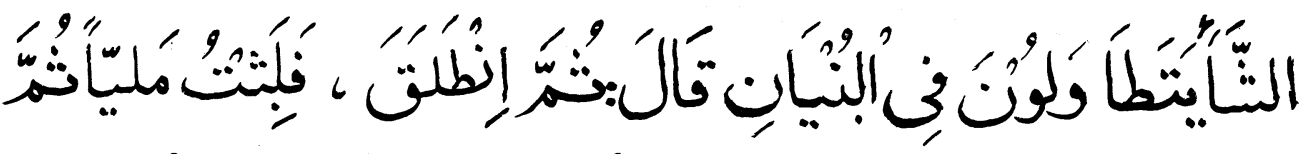

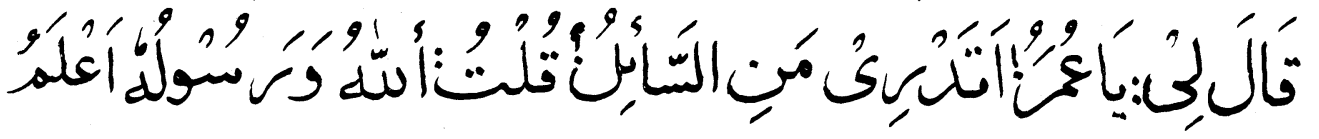

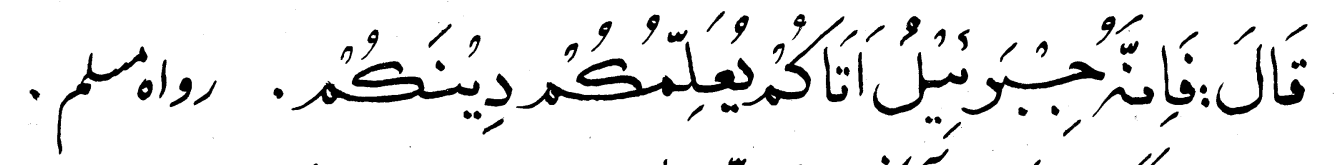

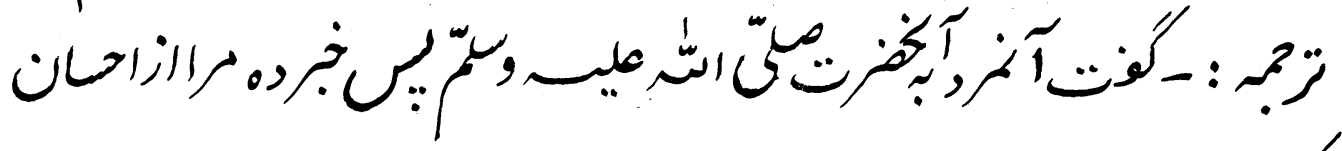

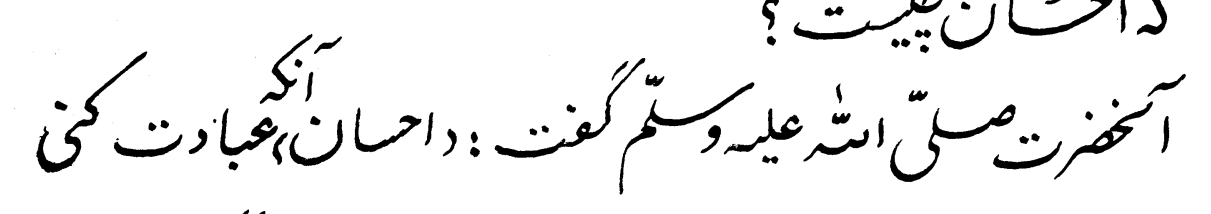

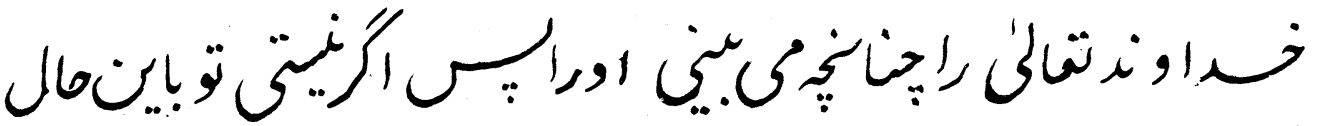

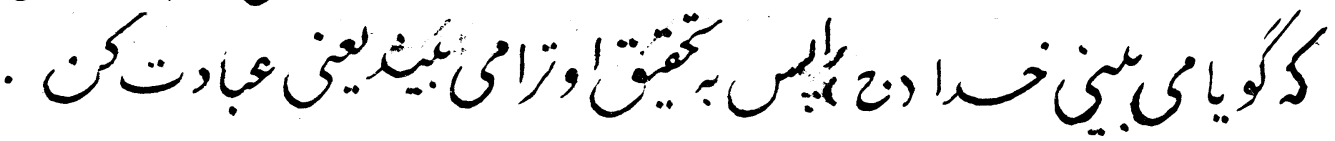

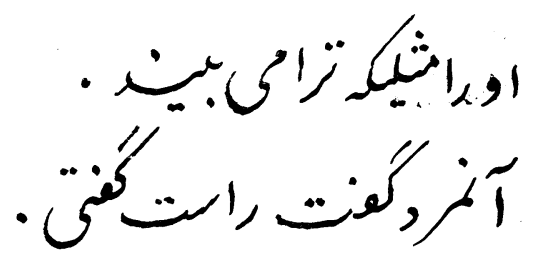




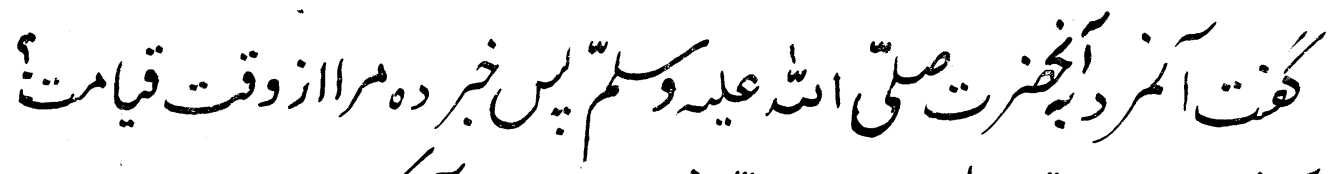

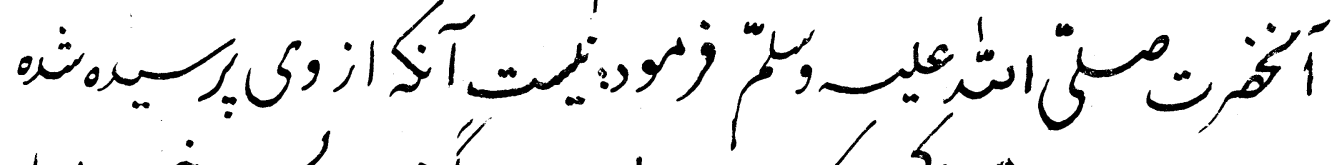

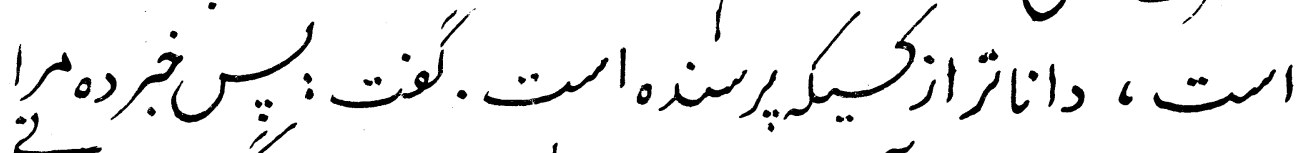

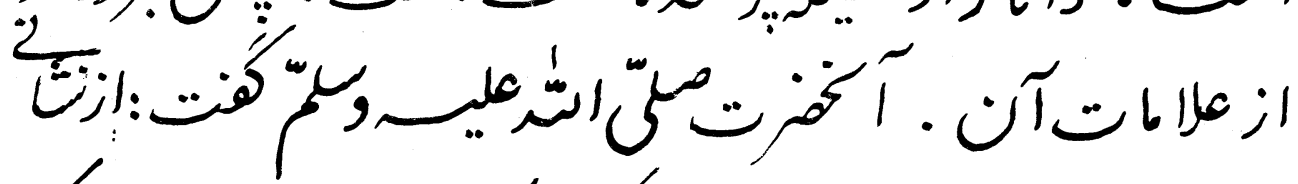

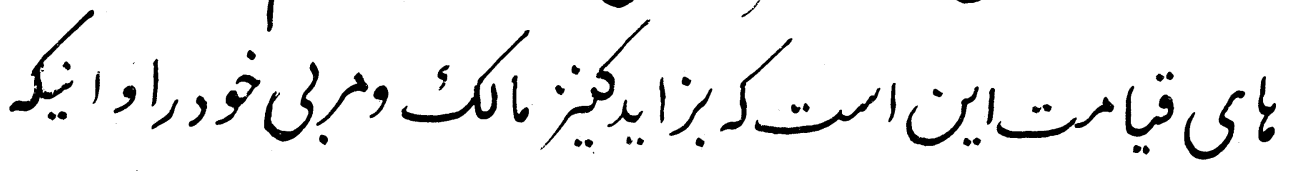

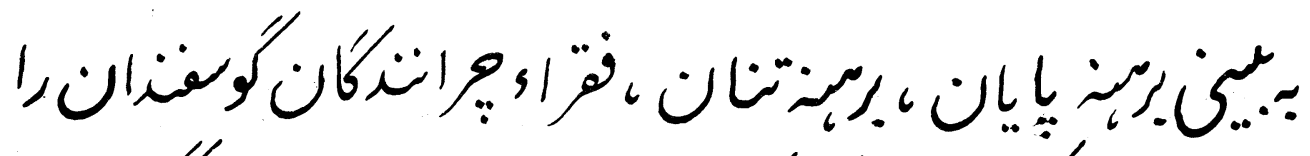

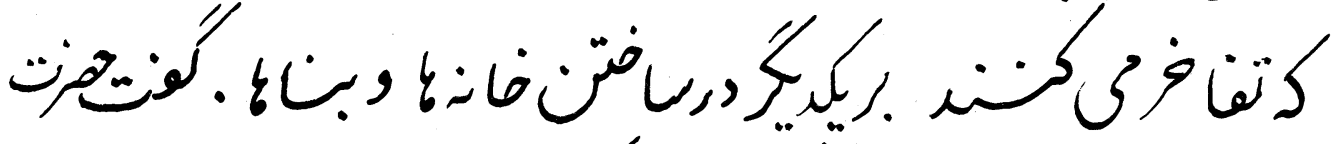

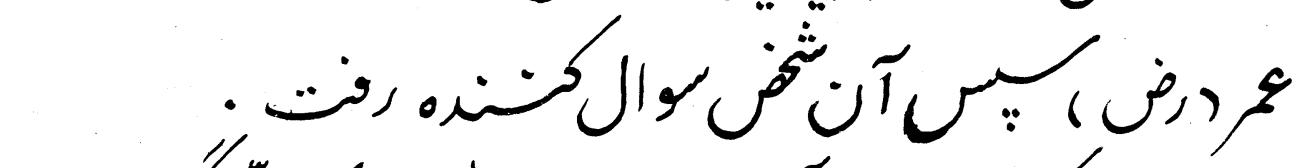

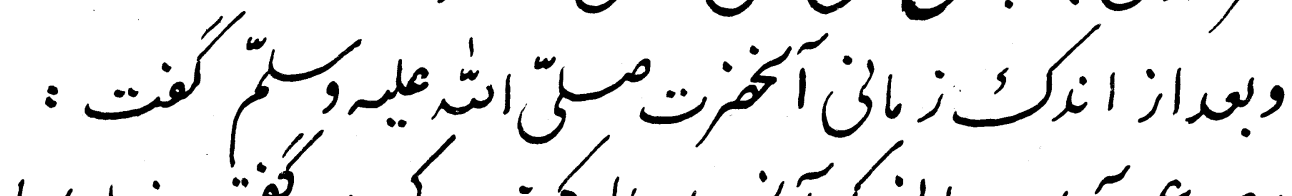

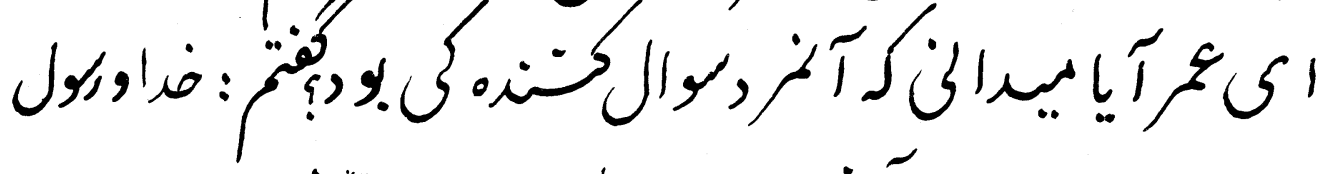

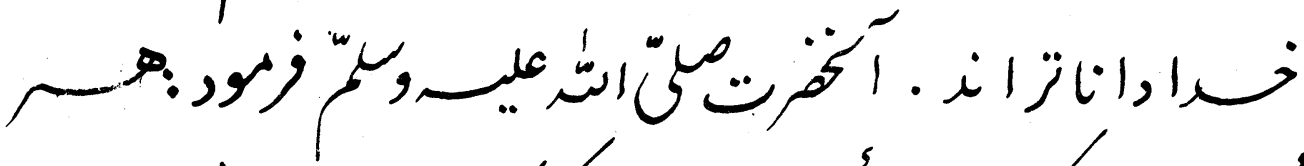

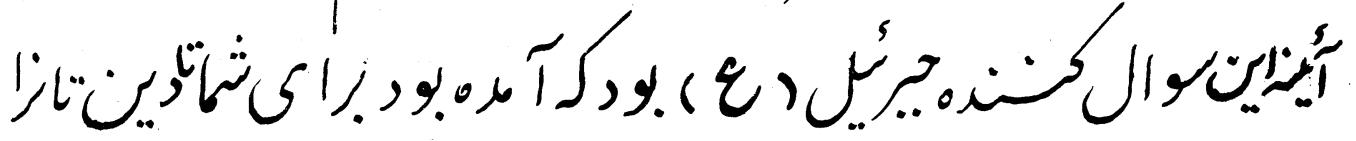

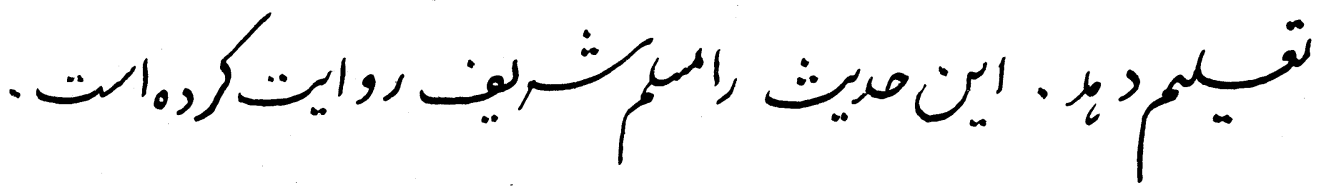




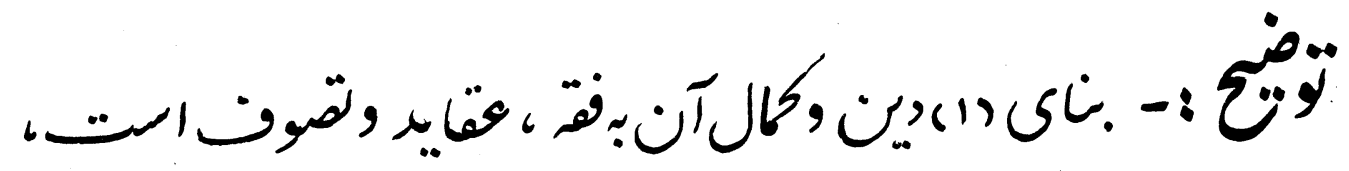

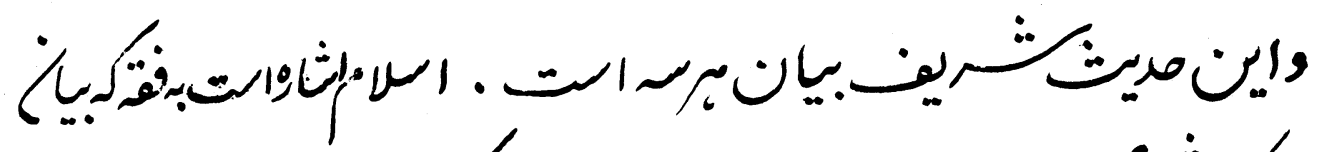

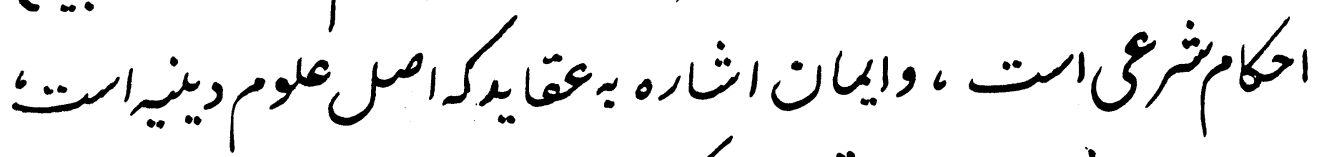

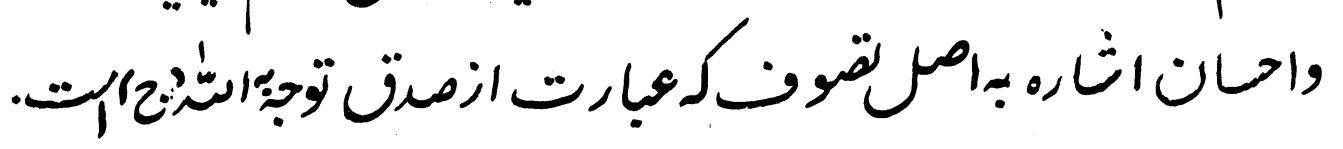

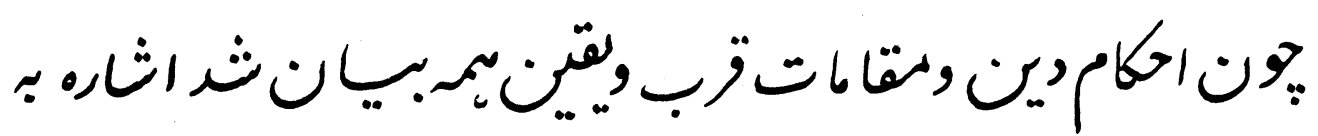

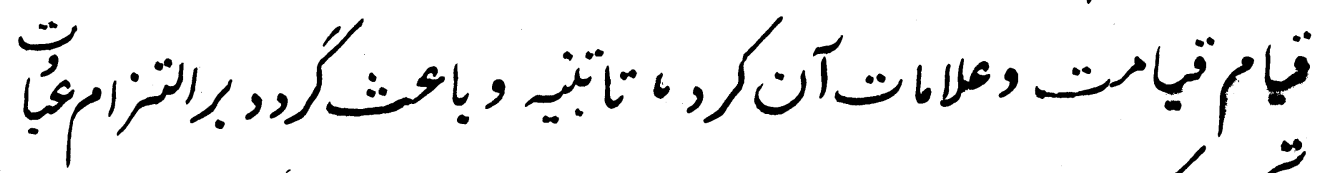

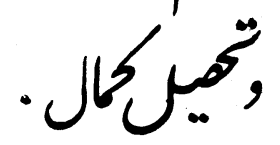

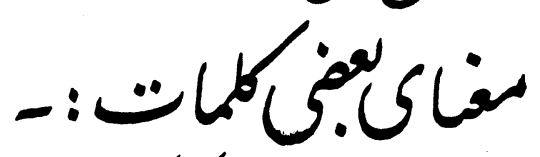

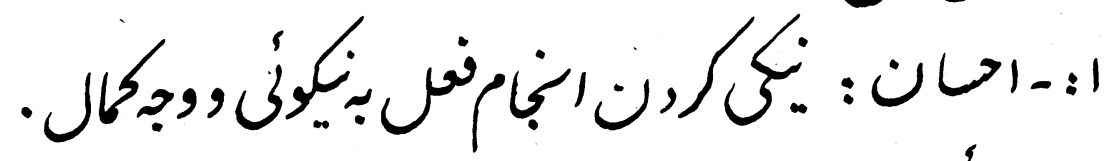

r:

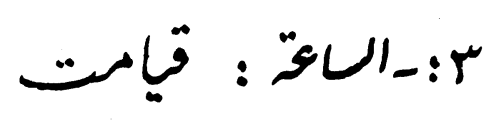

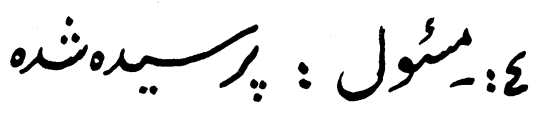

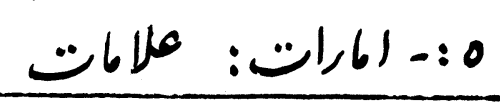

40 1)

11 


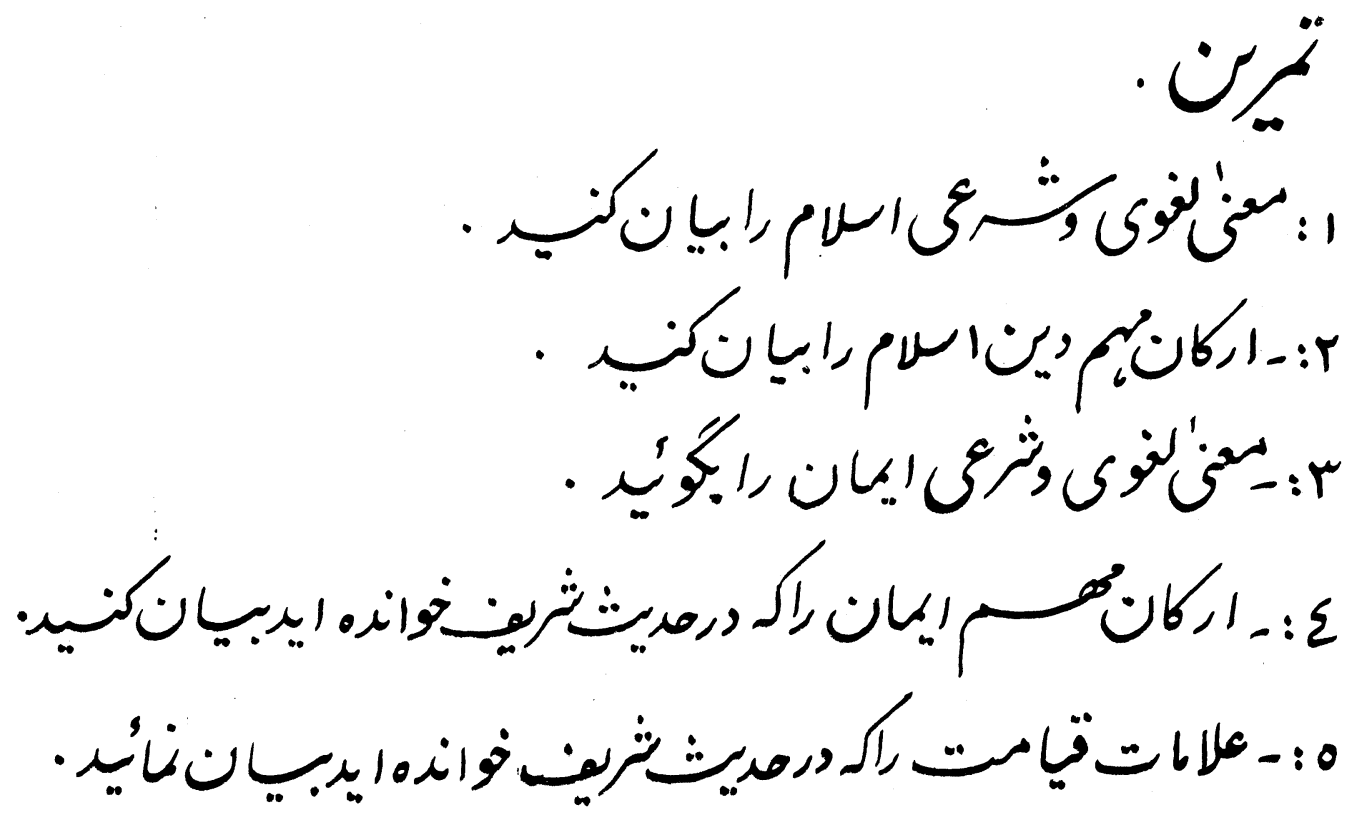

19 


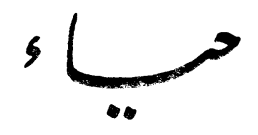

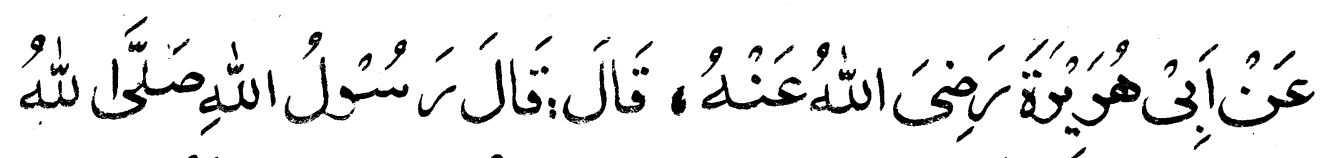

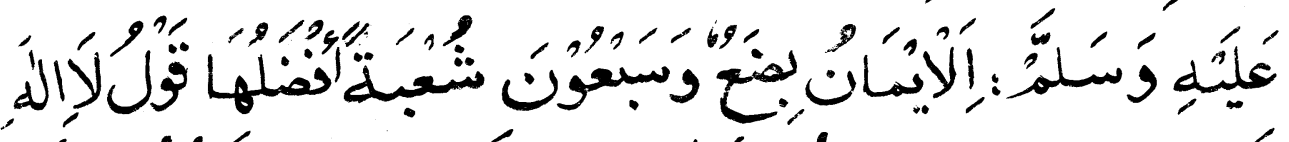

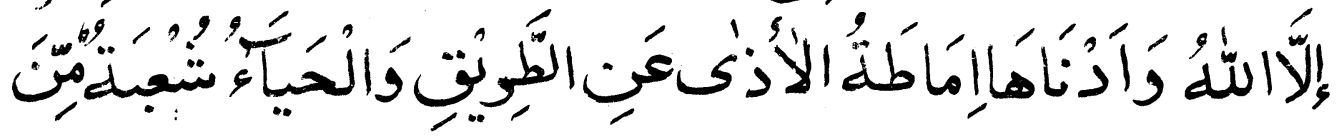

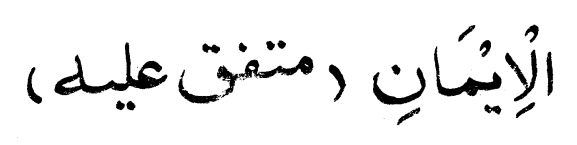

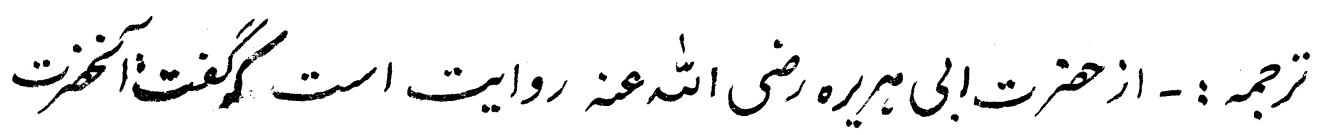

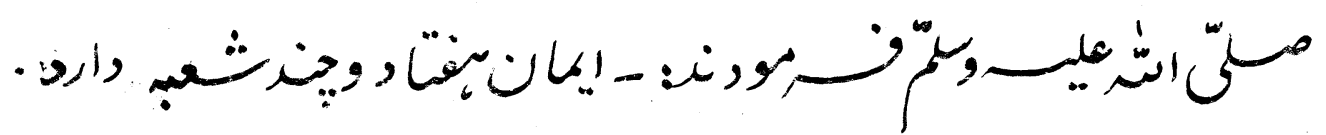

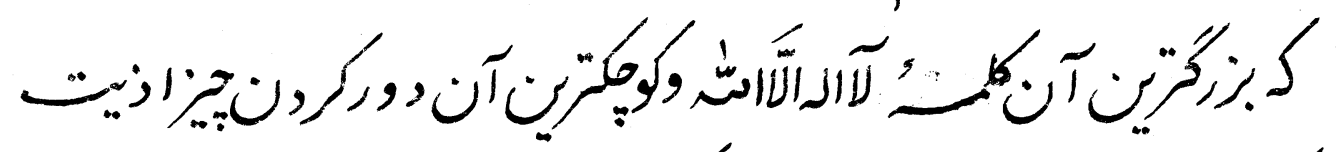

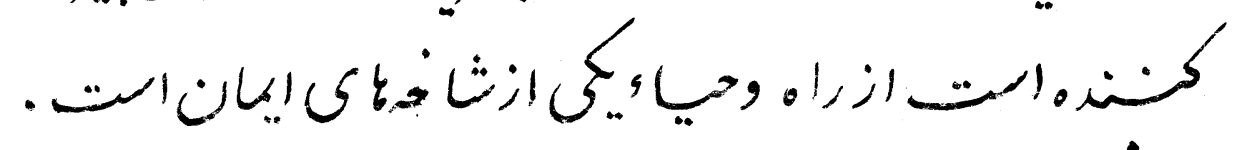

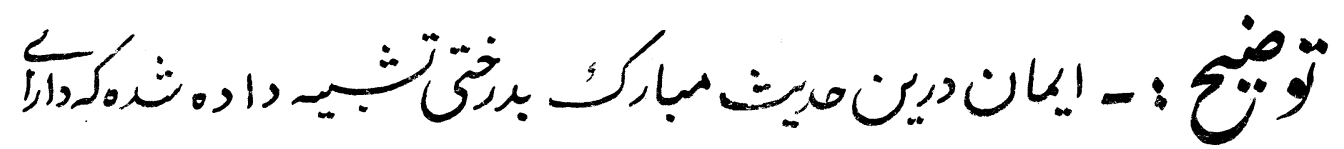

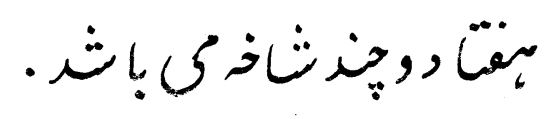

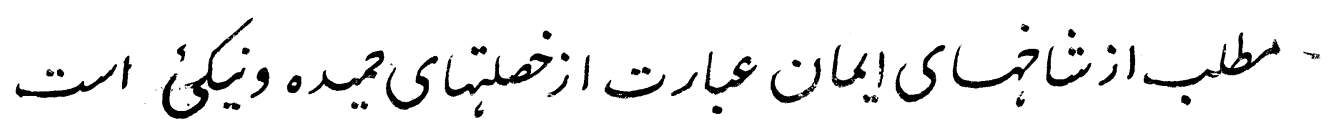

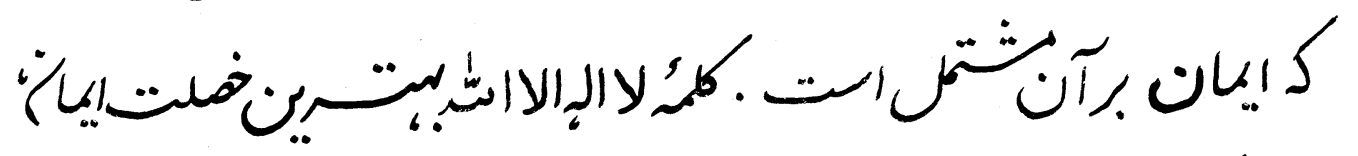

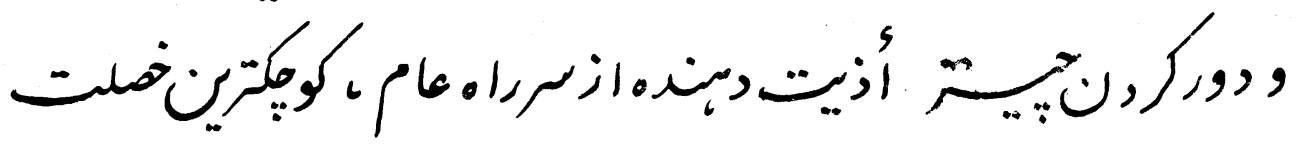
إيانان 


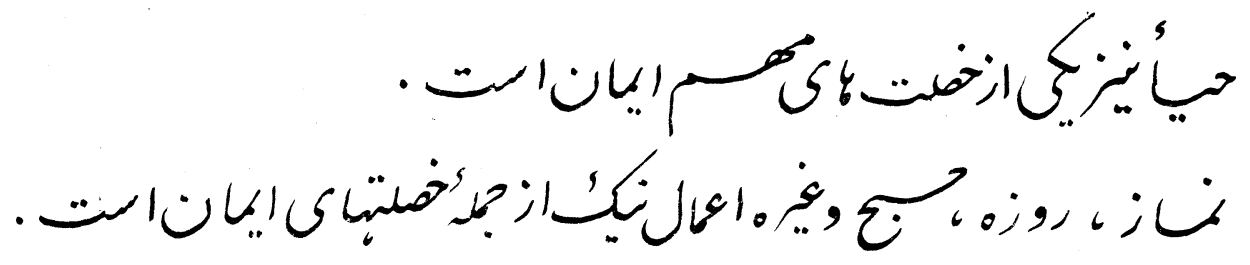

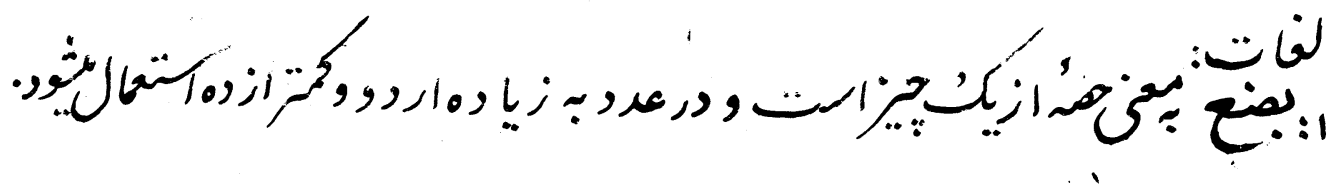

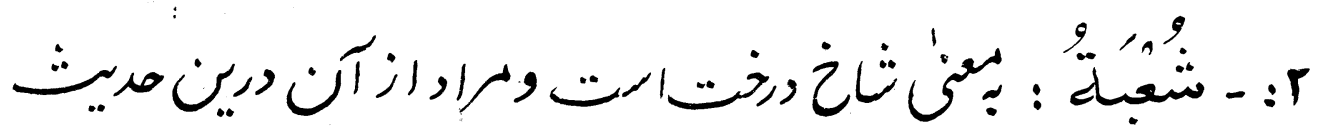
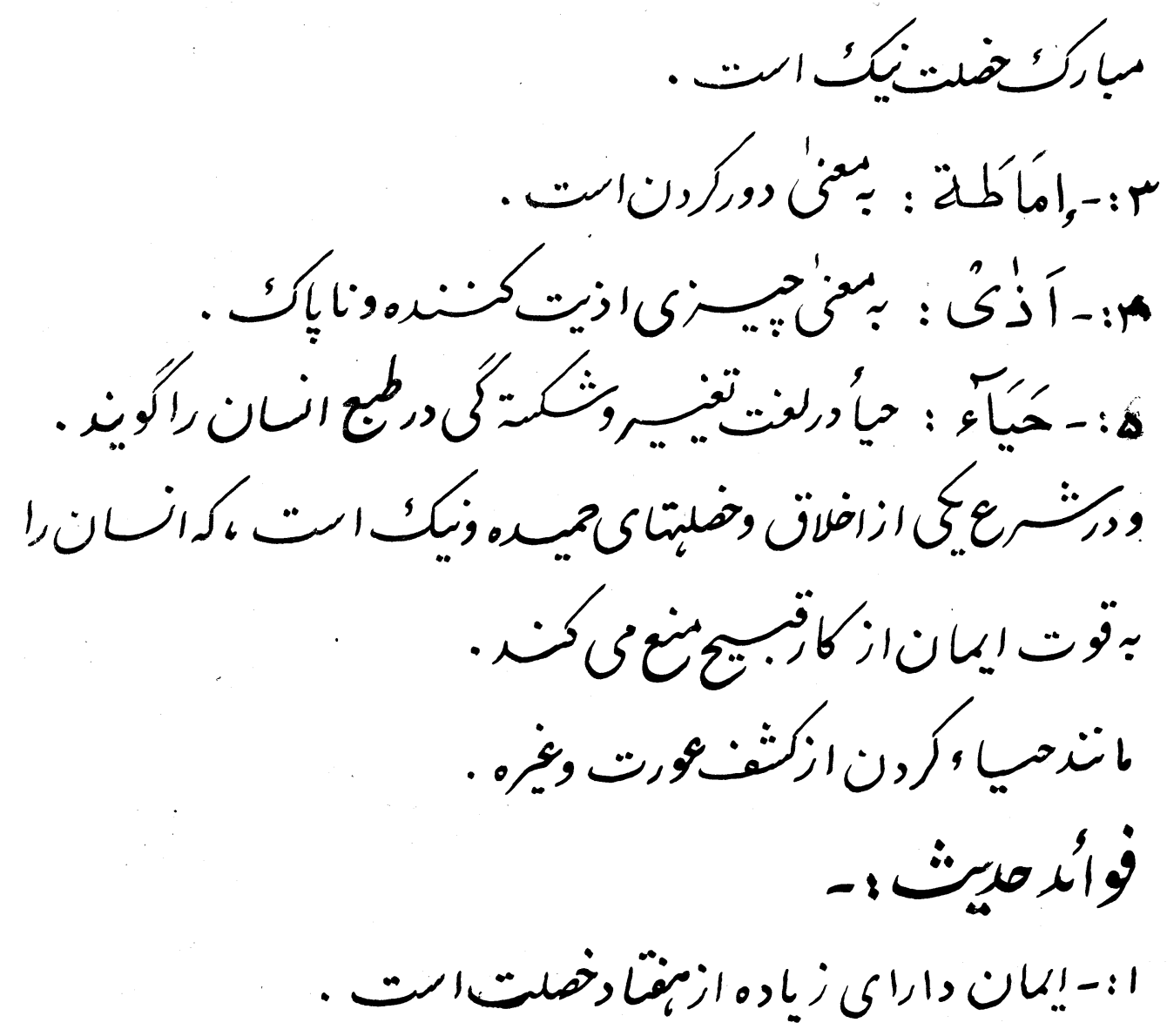

YI 


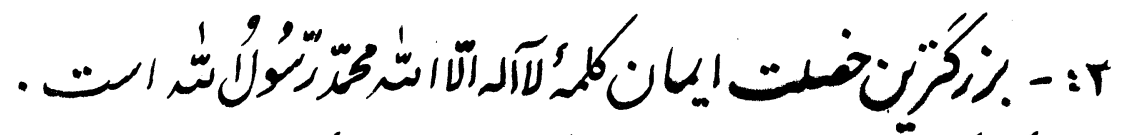

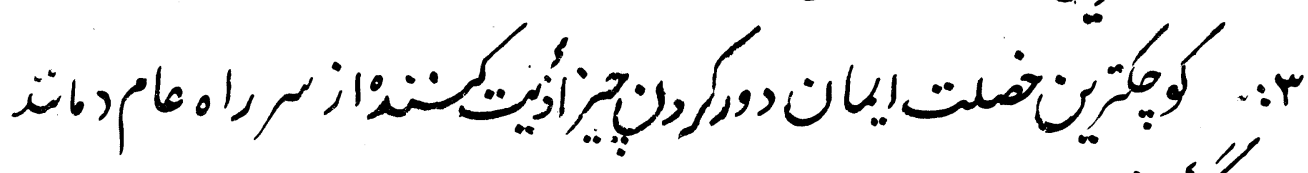

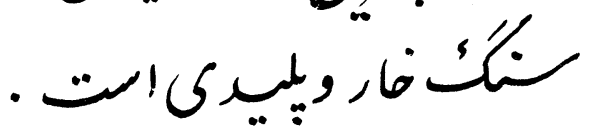

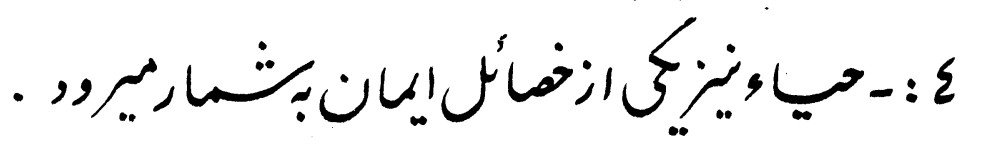

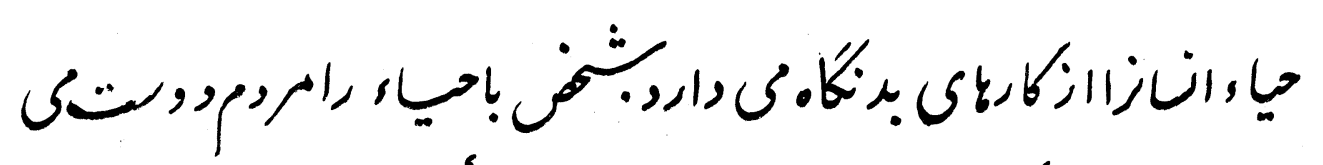

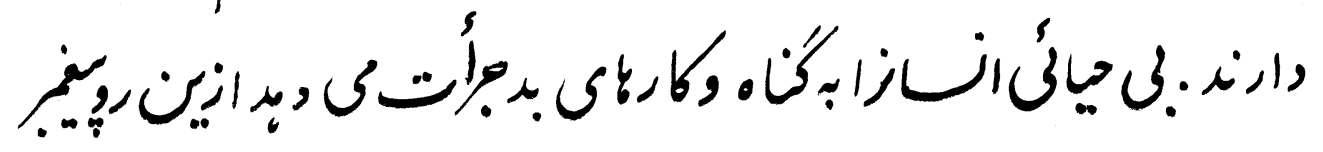

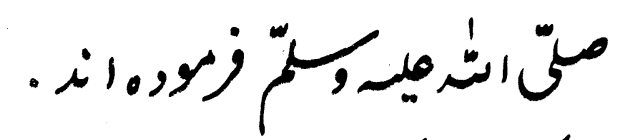
"

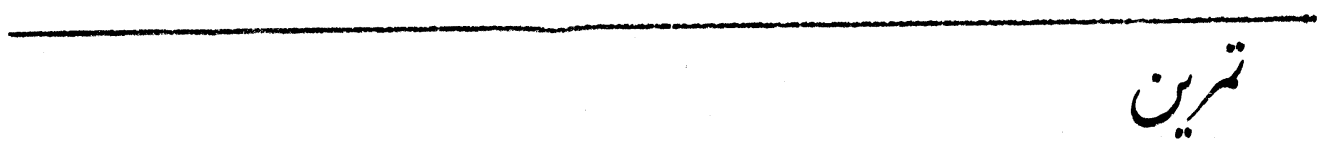

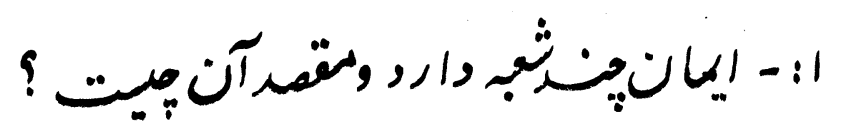

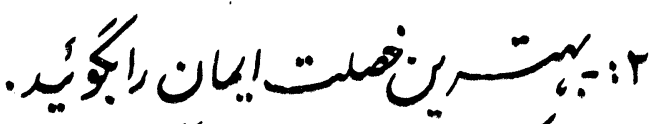

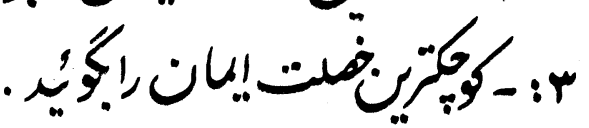

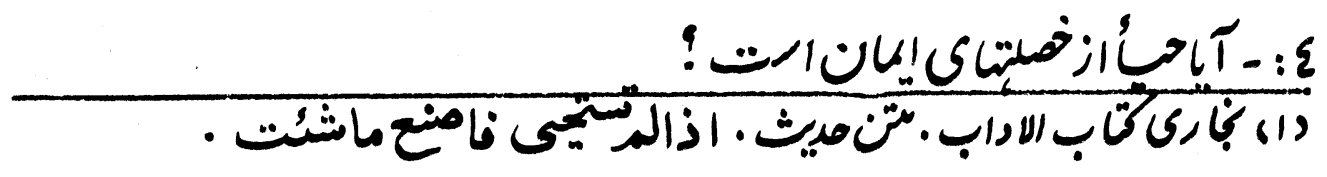

rr 


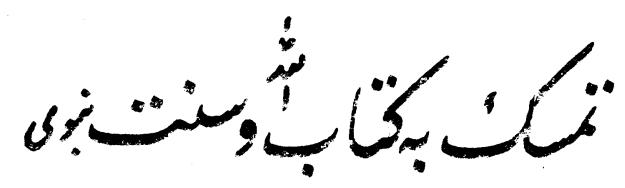

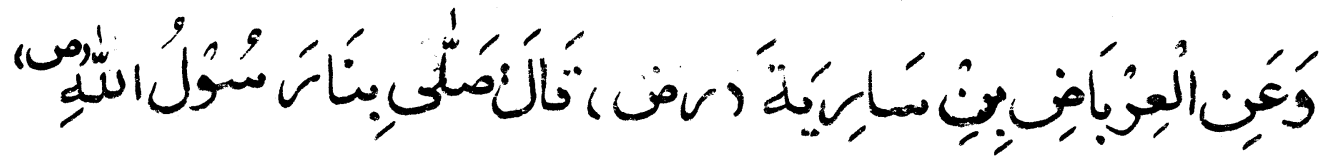

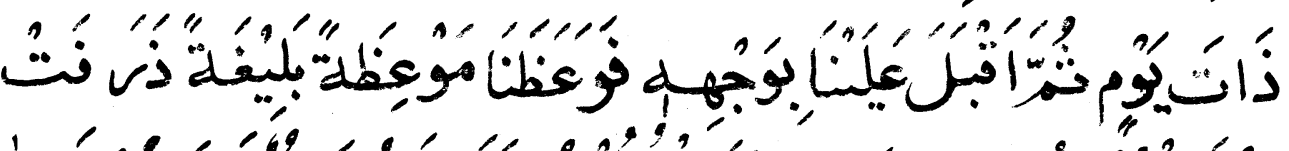

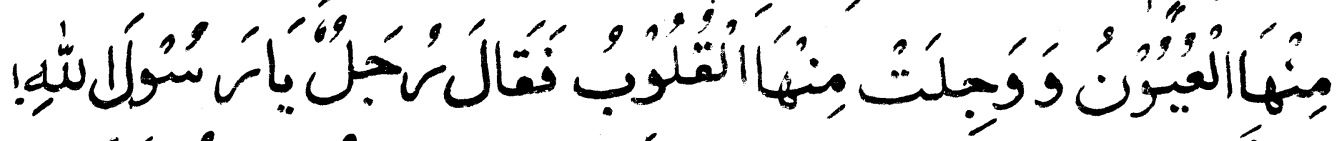

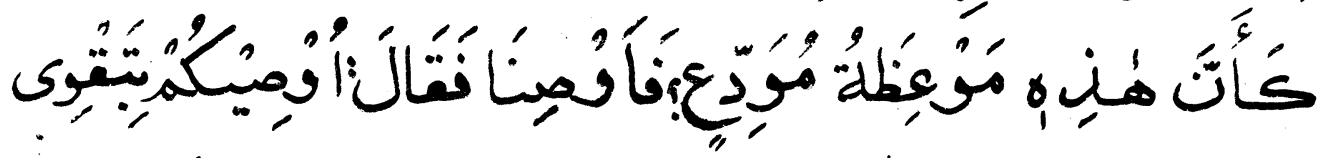

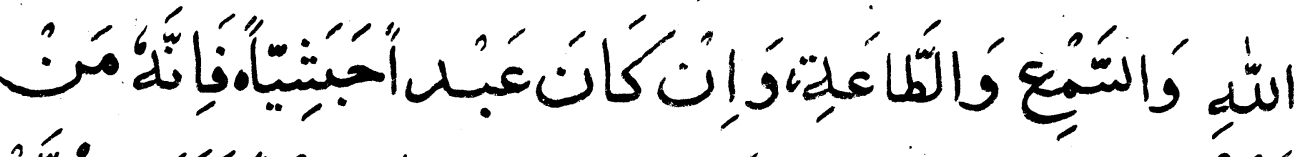

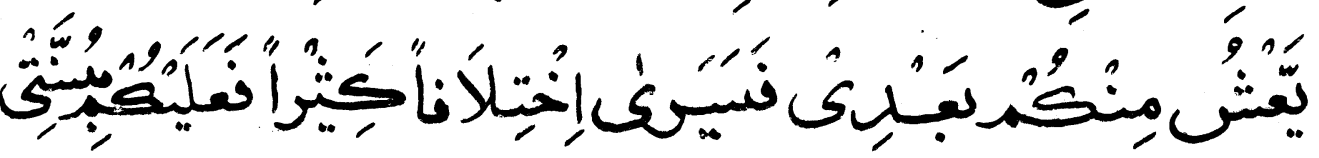

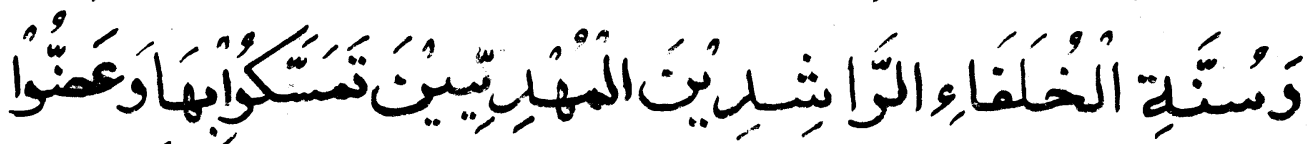

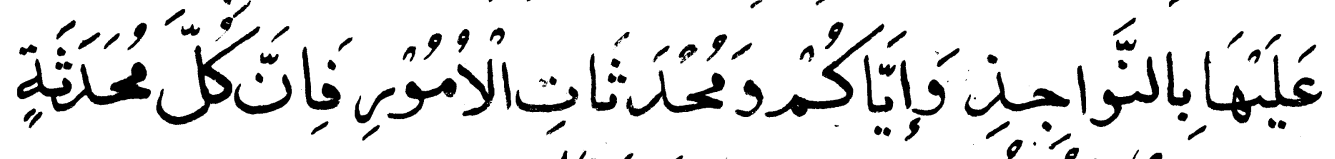

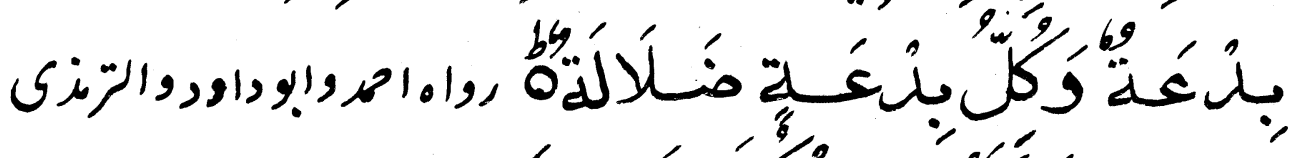

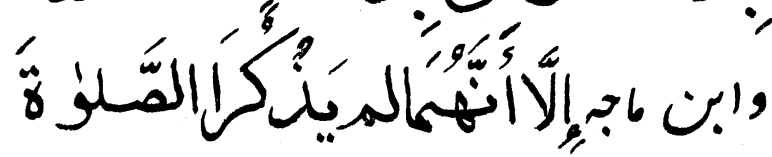

زبم: :-

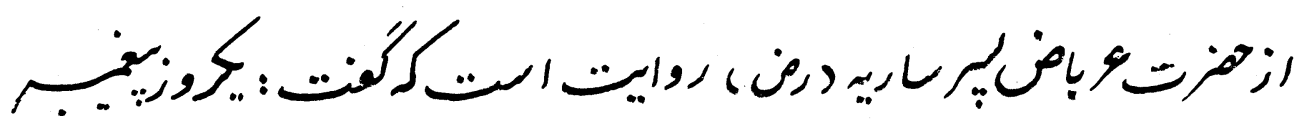

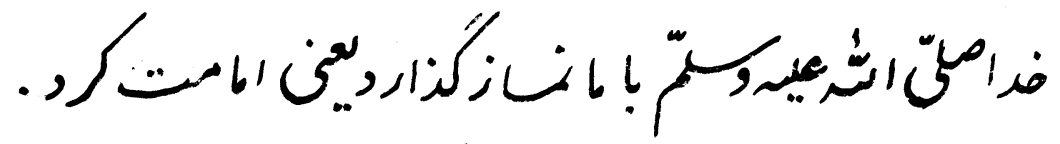

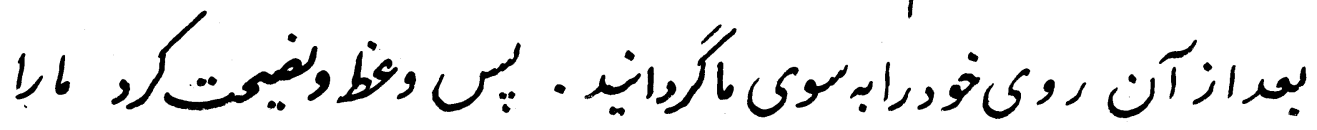
* Yr 


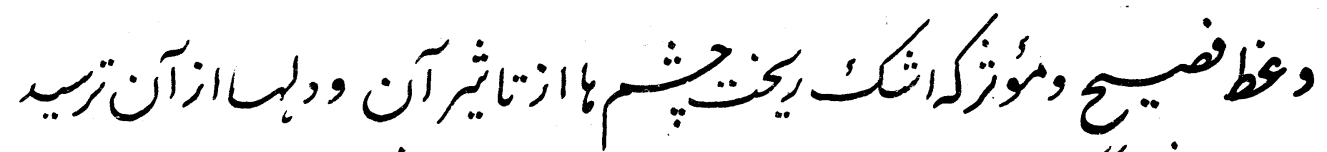

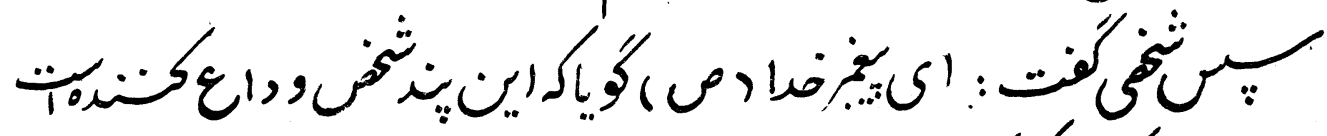

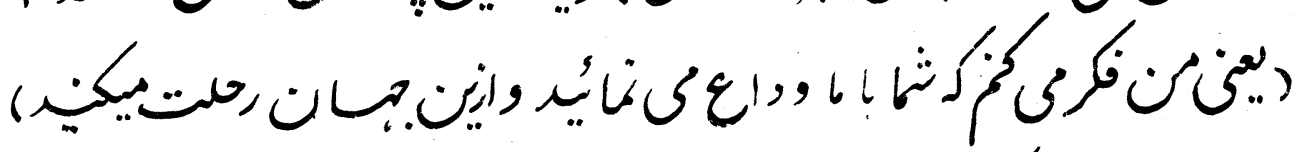
:

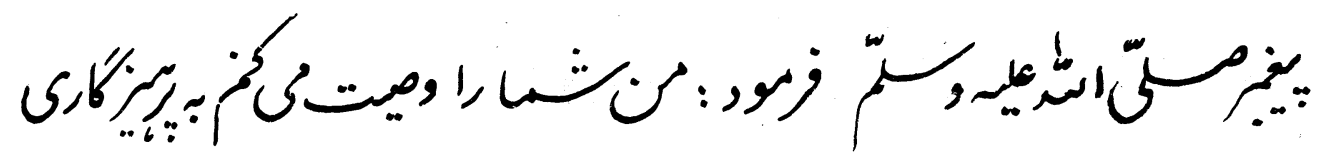

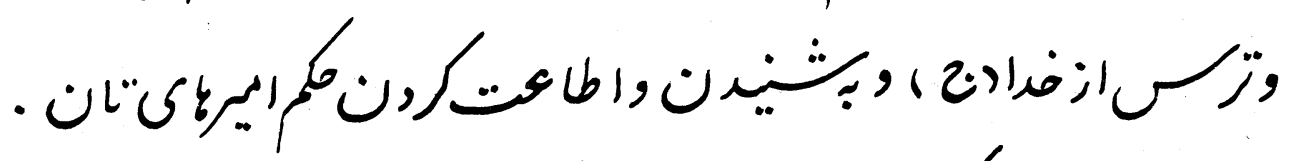

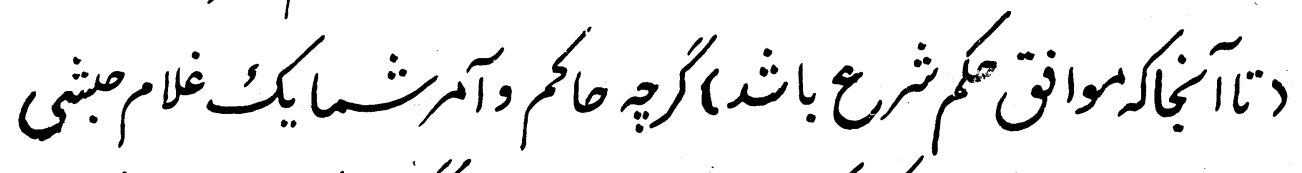

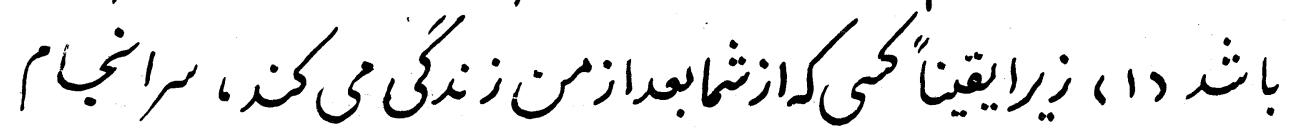

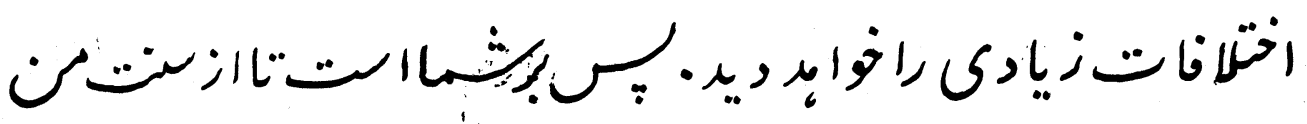

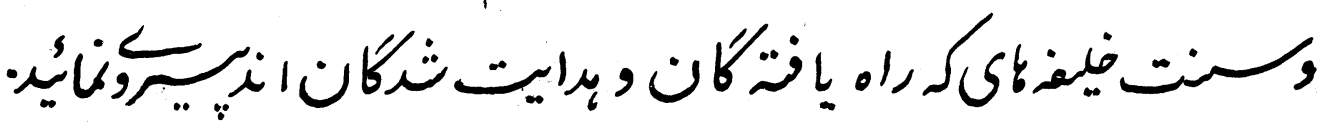

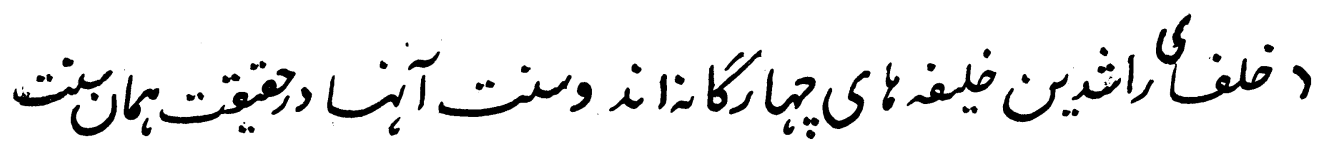

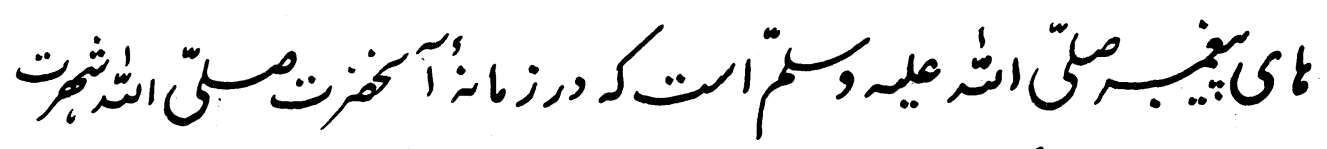

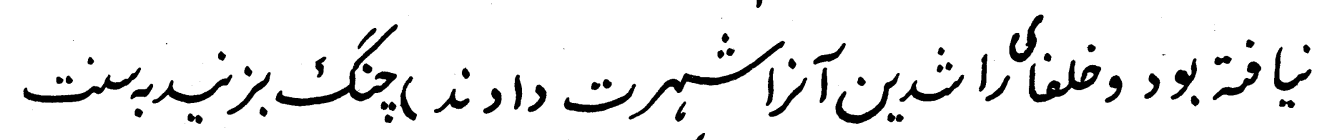

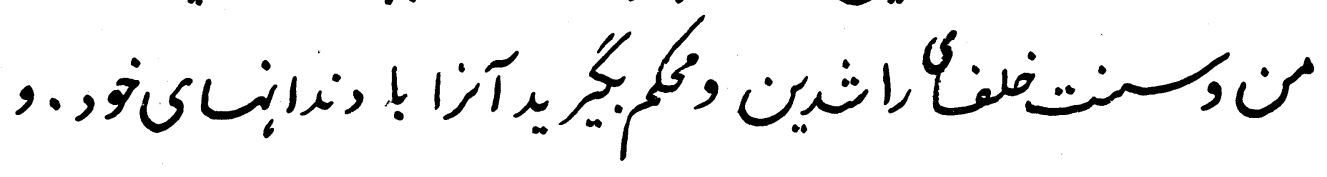

Yf 


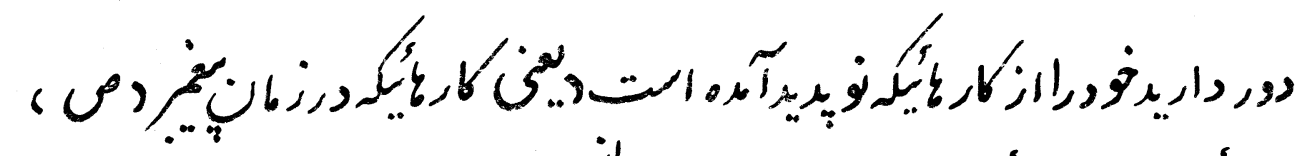

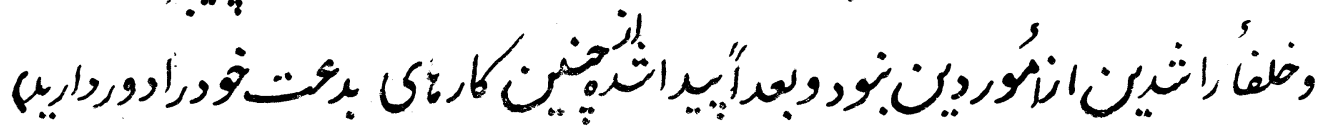

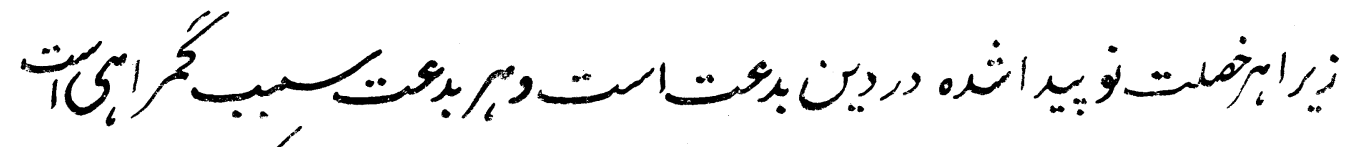

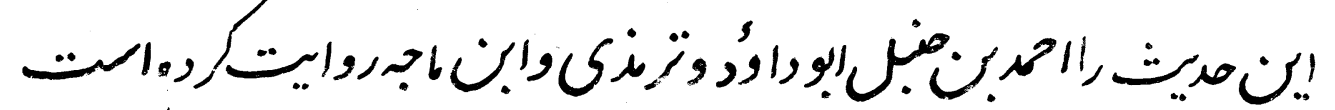

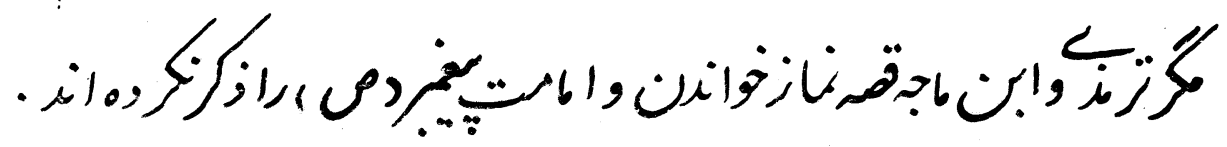

$$
\text { : }
$$

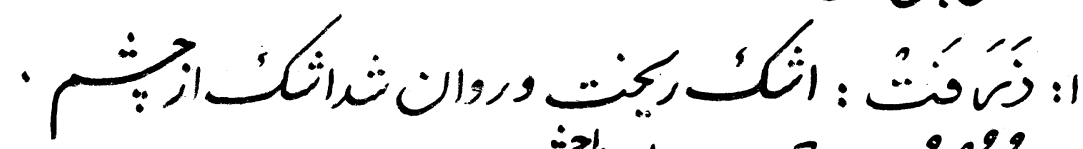

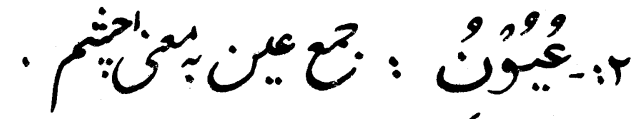

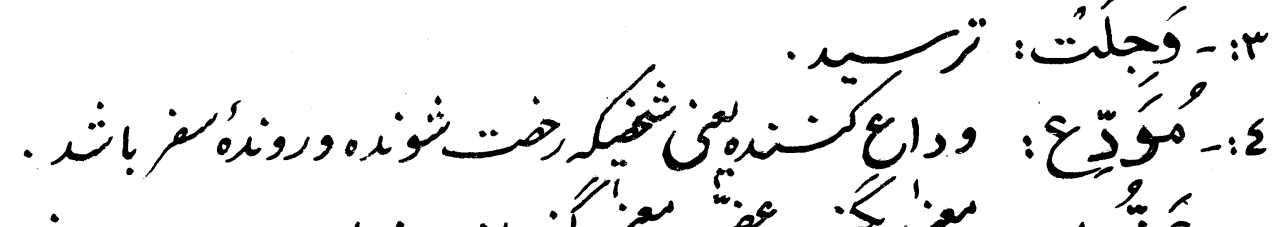

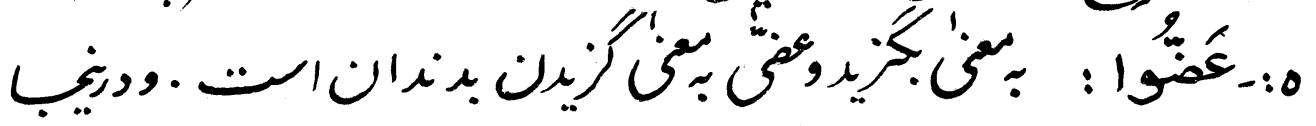

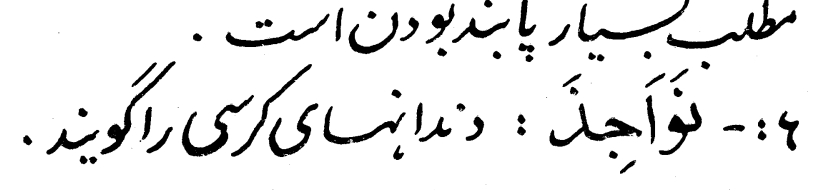

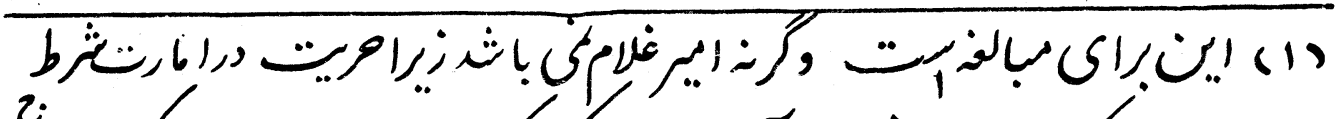

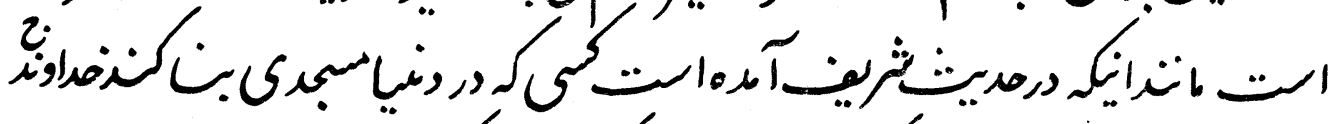

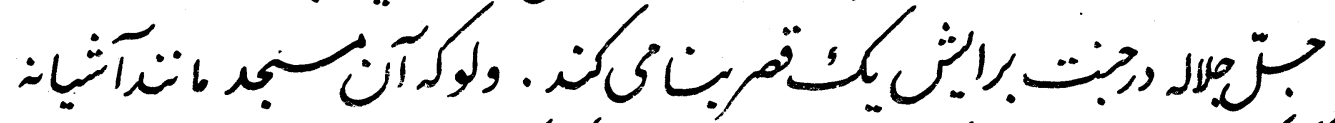

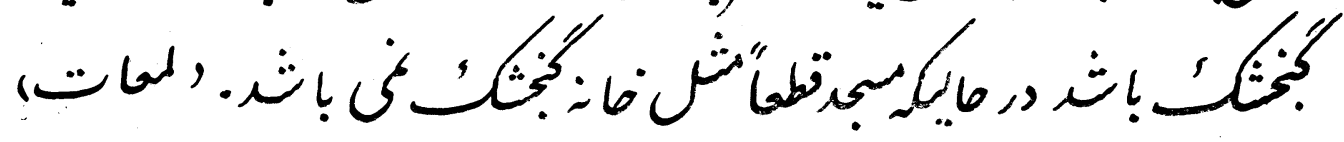




\section{فأرحست}

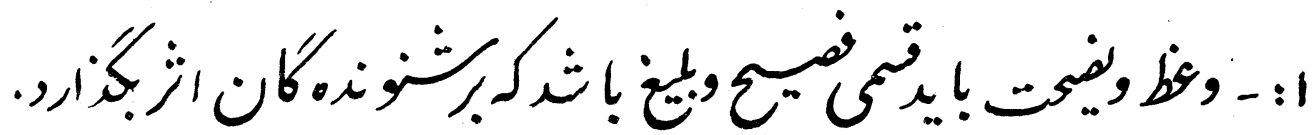

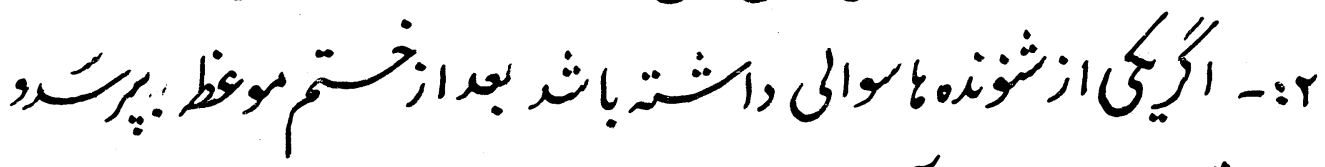

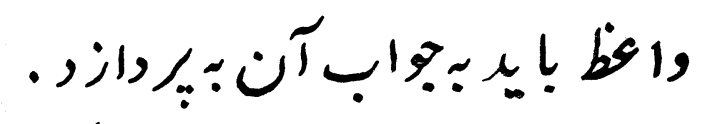

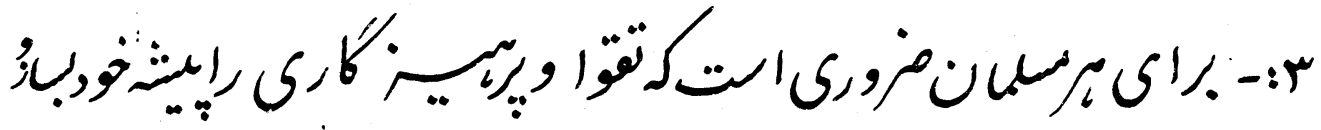

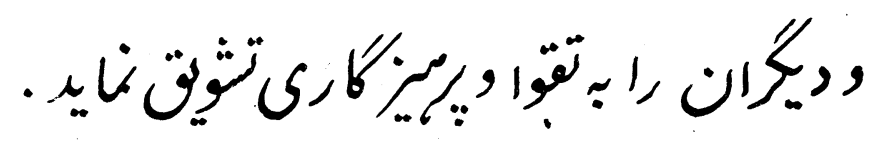

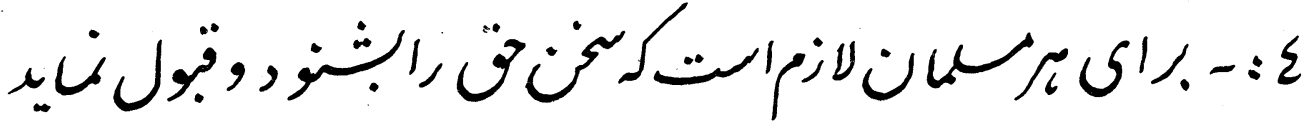

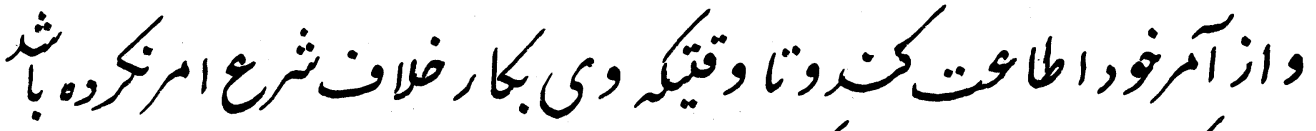
ازحكم وىبفاوت وركتينكن.

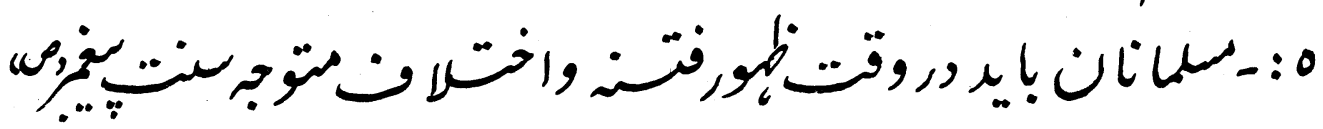

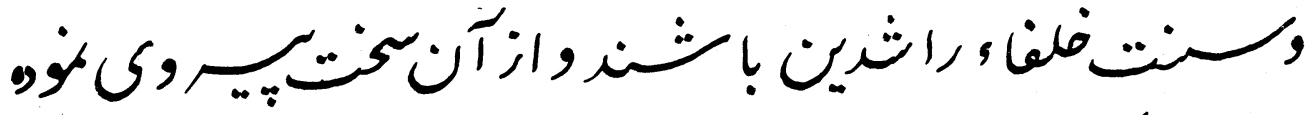

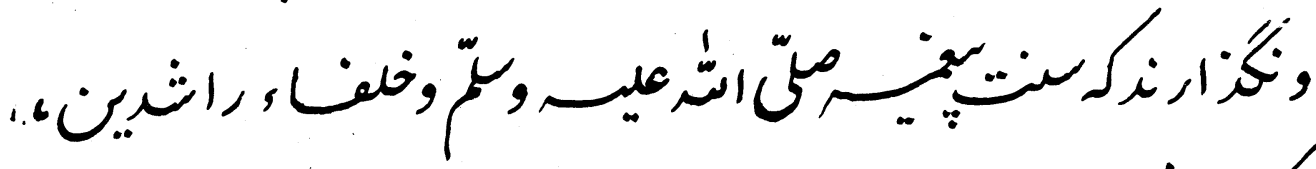

$$
\text { زكتثر }
$$

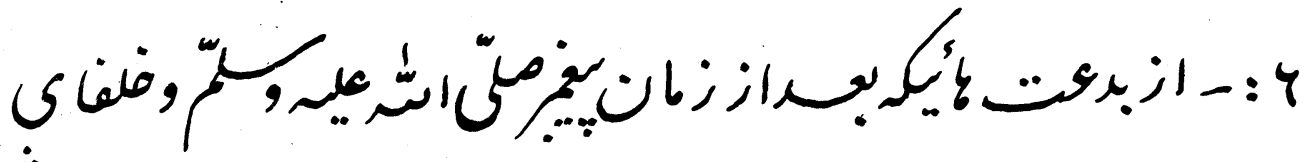

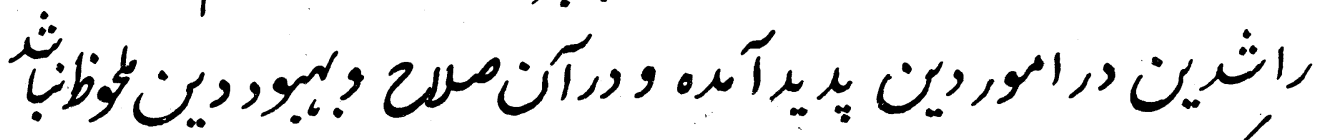

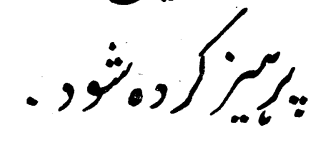

Tr 


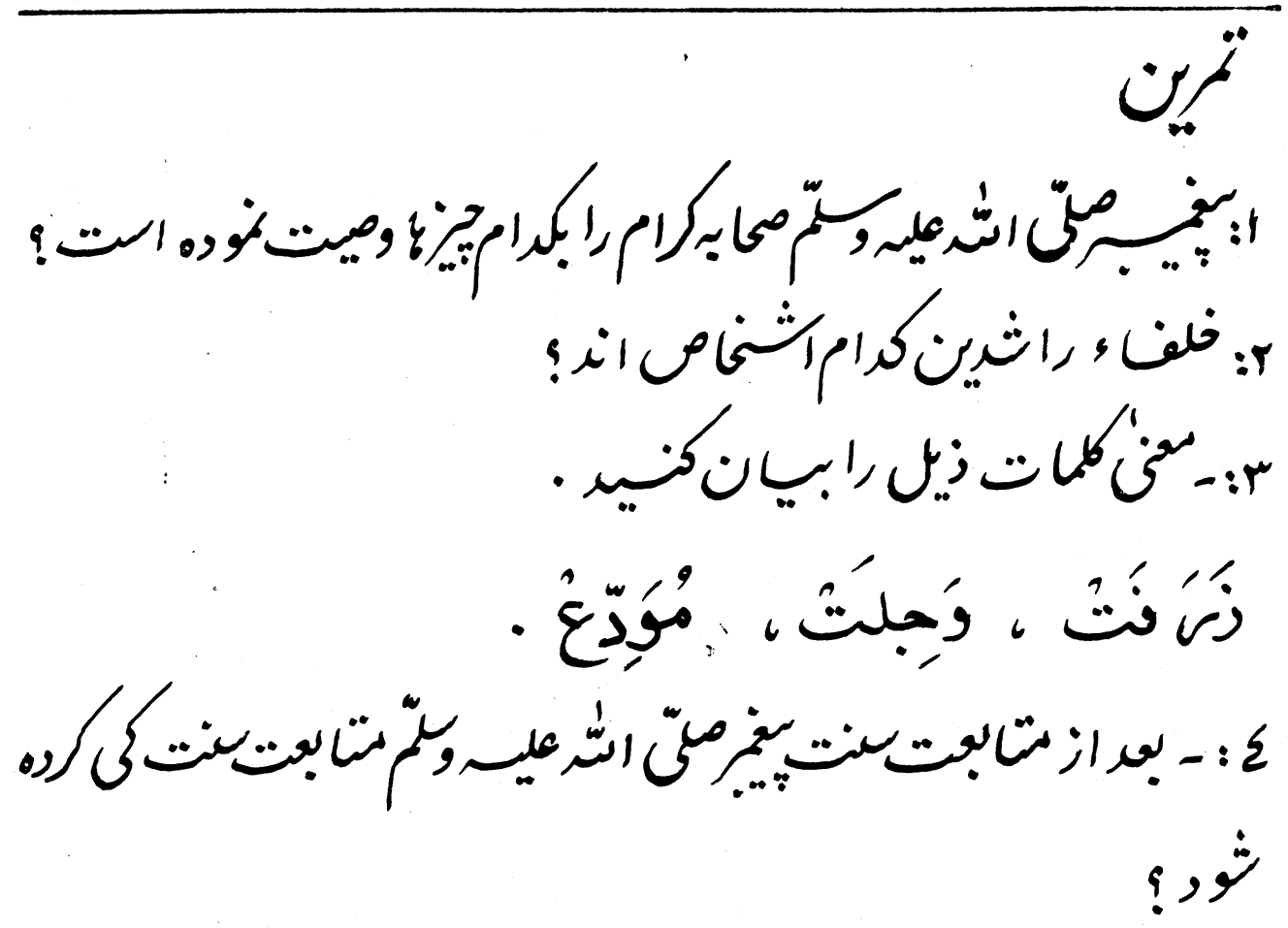

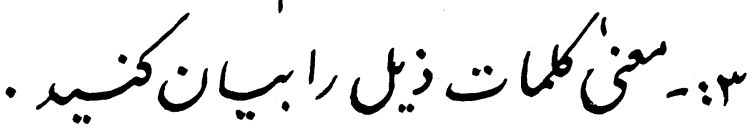

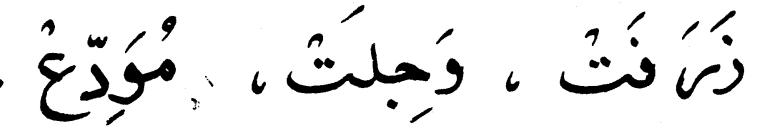

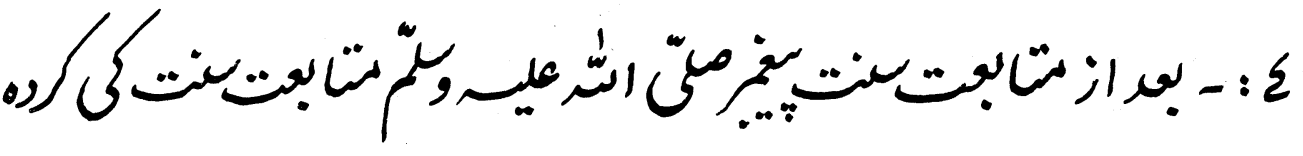$$
\text { ? }
$$ 


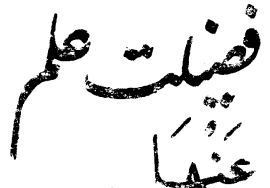

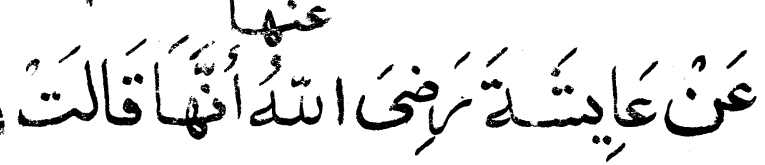

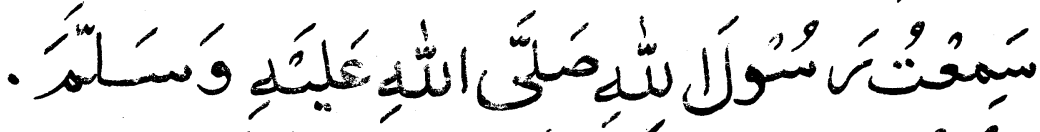

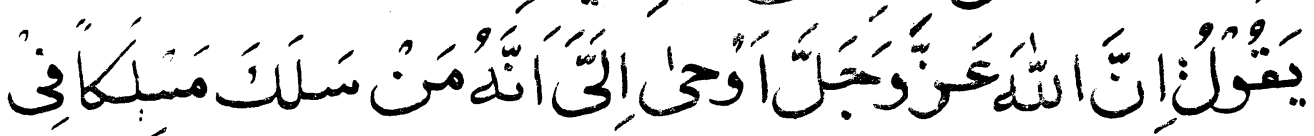

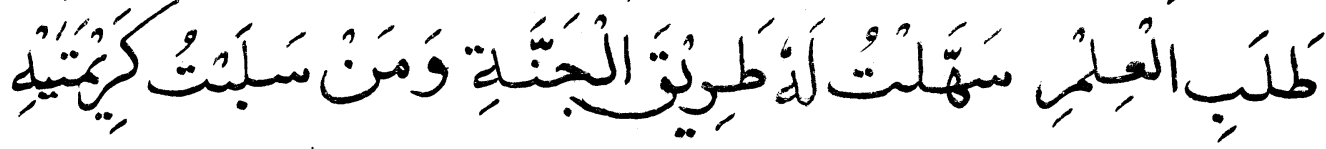

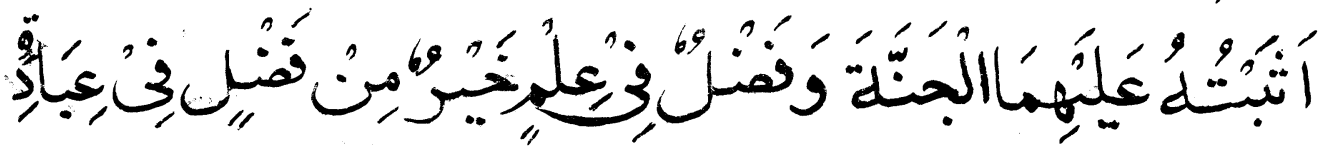

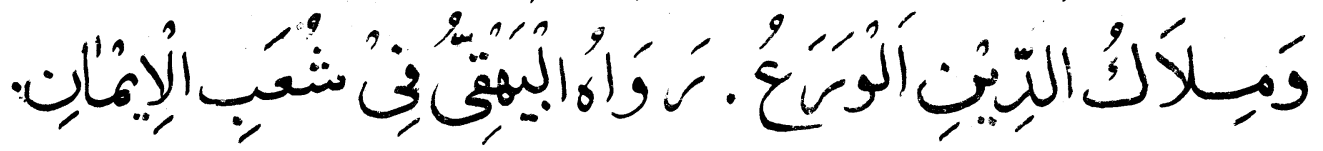
"קים:-

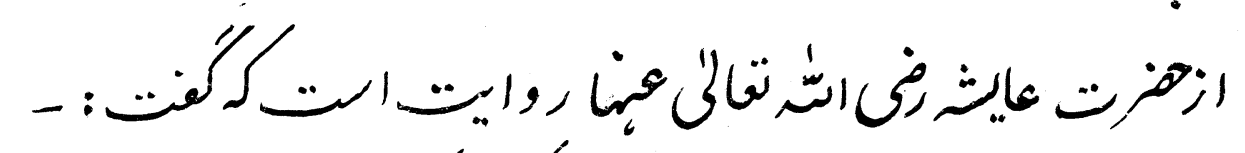

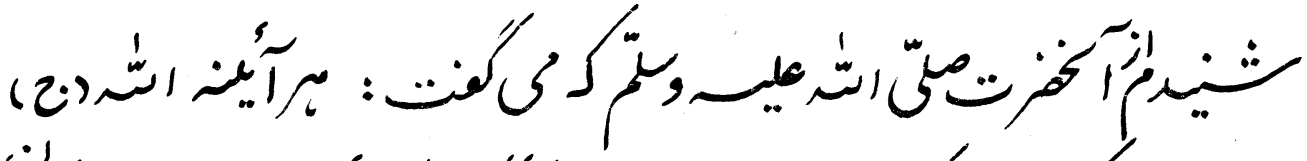

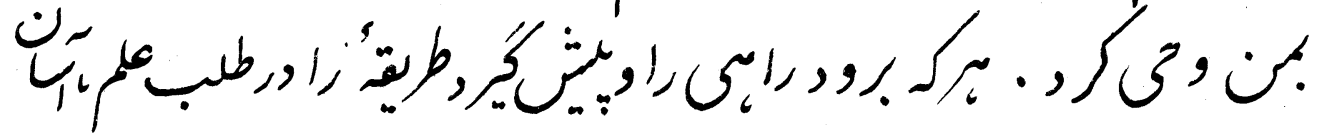

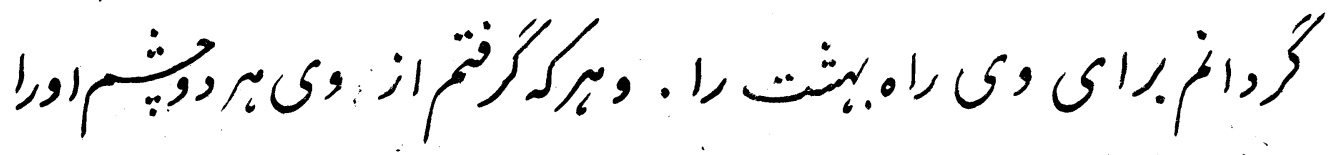

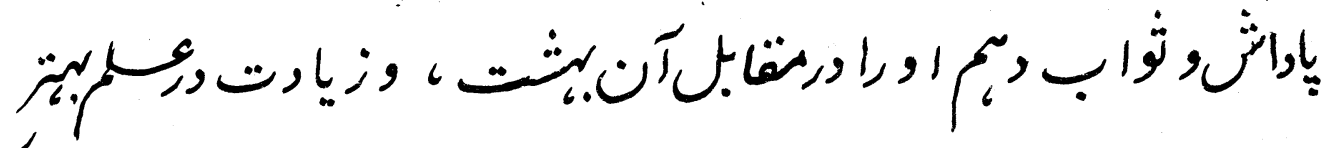

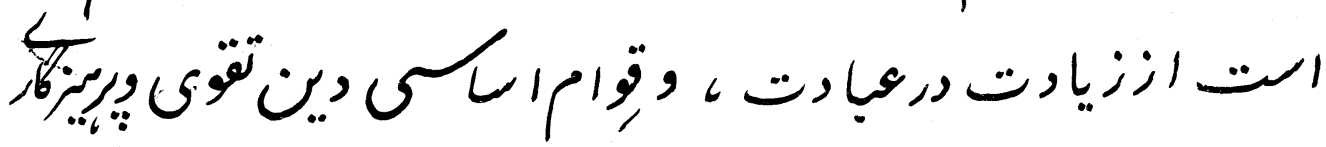




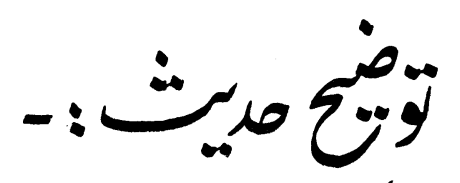

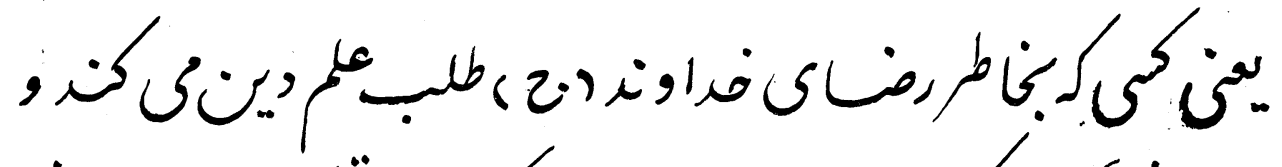

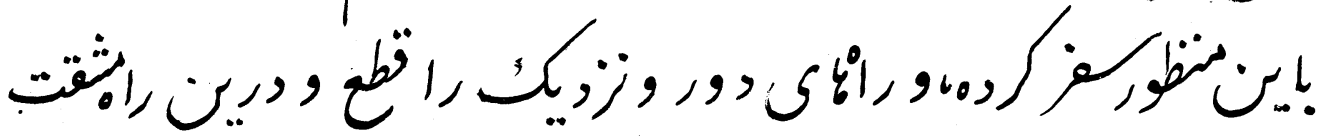

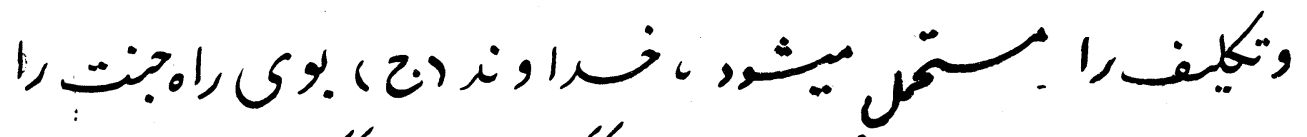

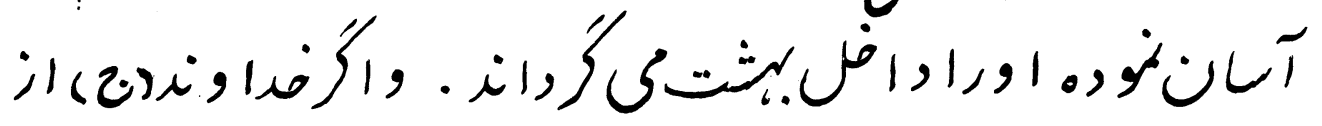

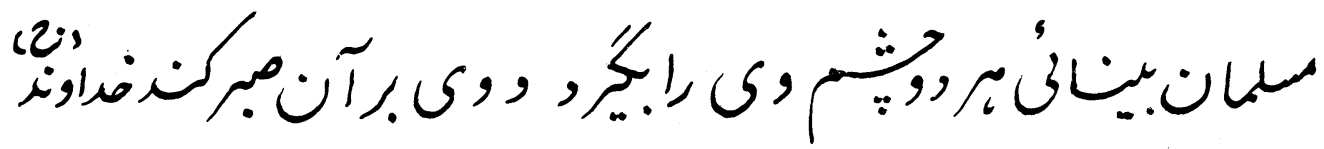

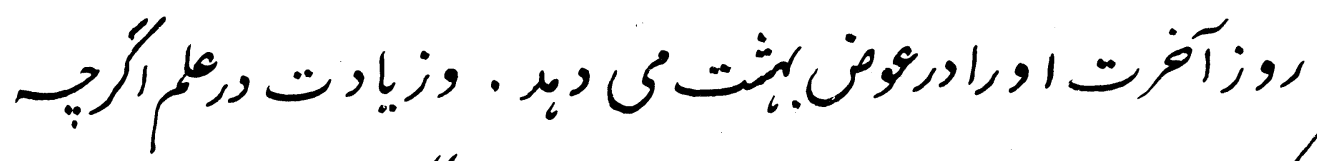

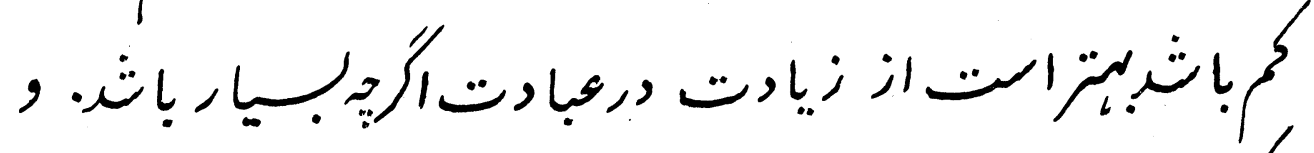

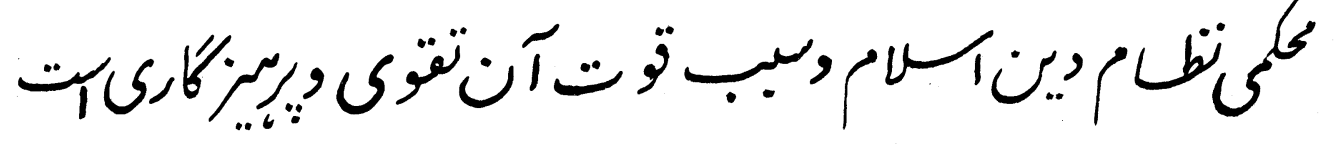

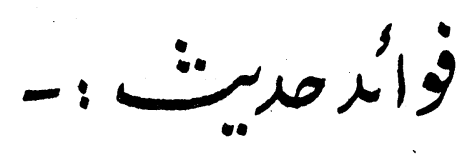

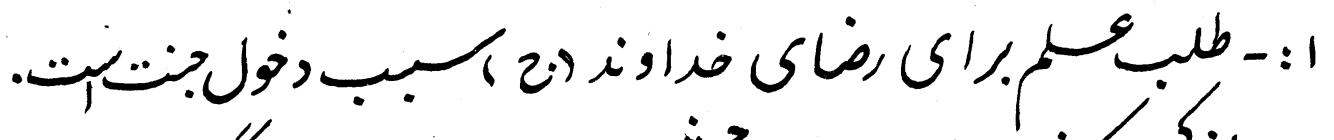

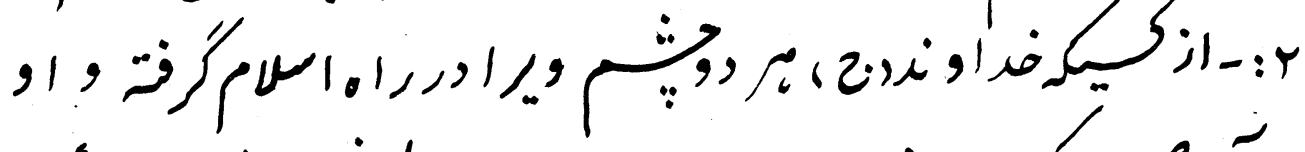

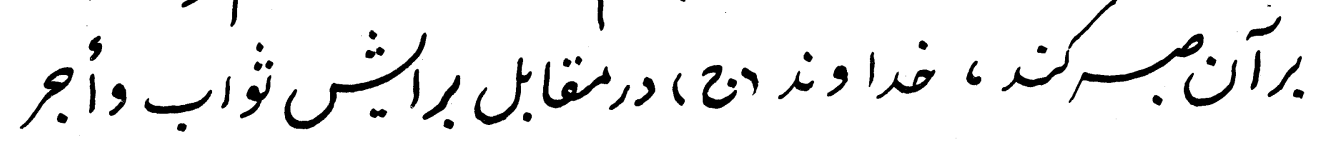

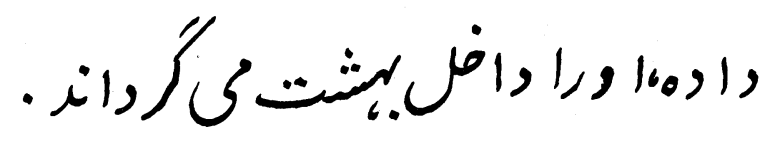

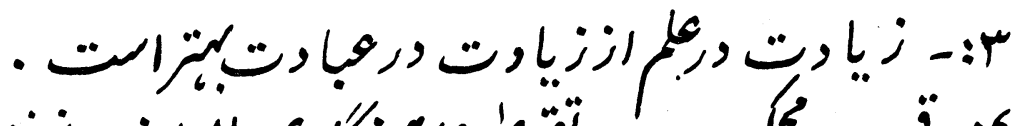

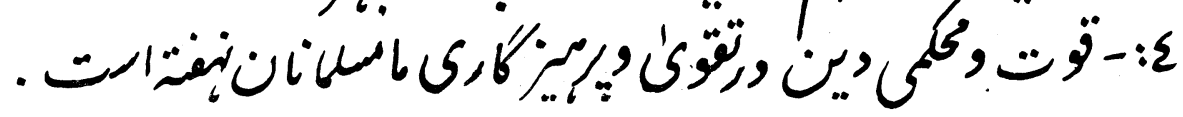
Yq 


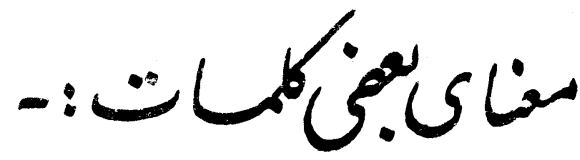

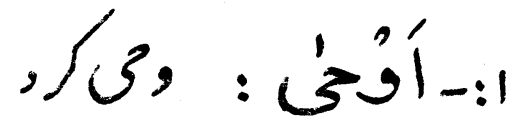

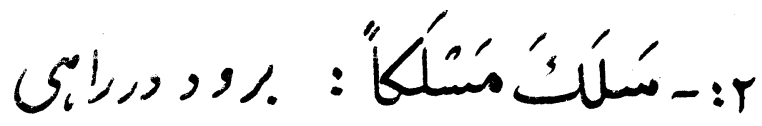

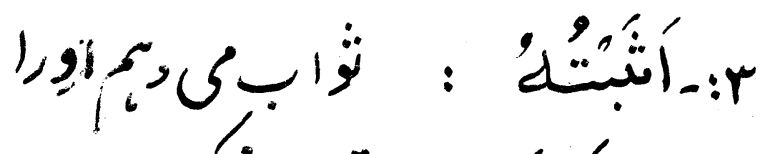

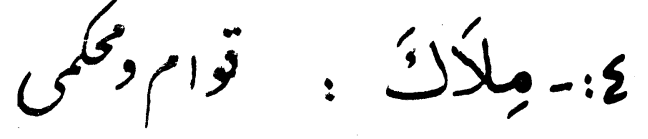

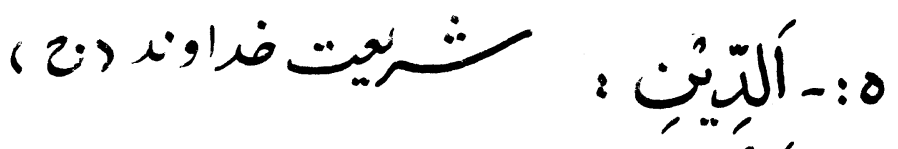

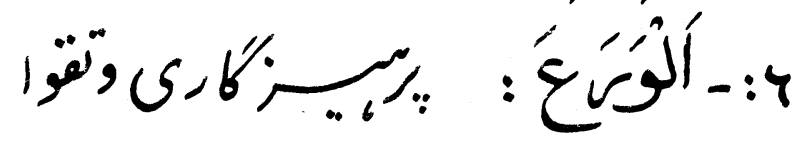

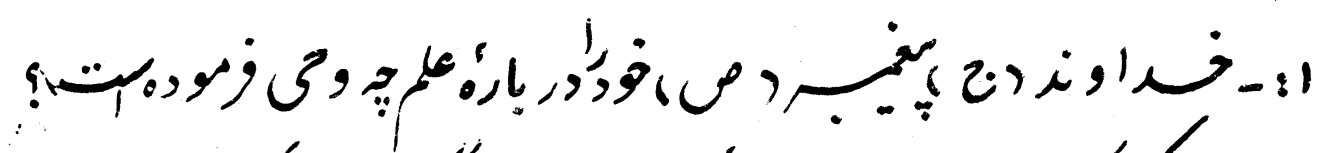

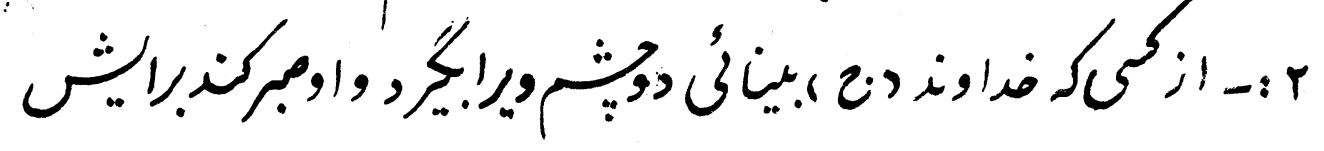

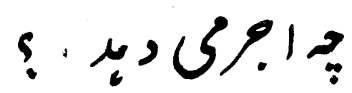

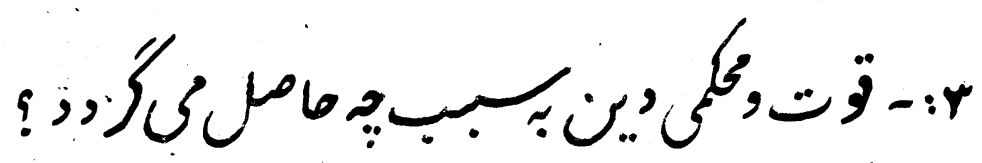




\section{تطنافت}

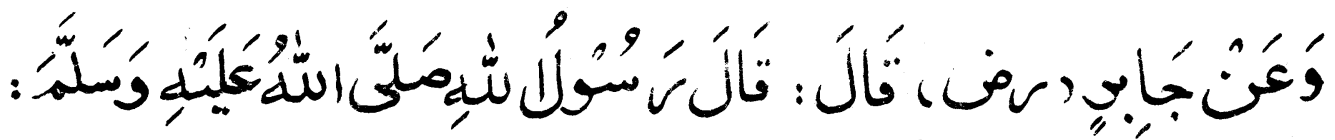

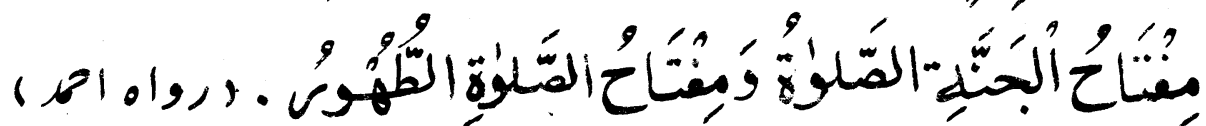

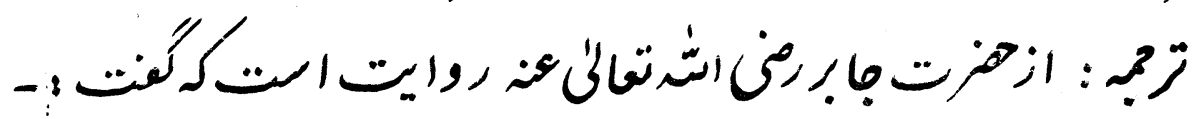

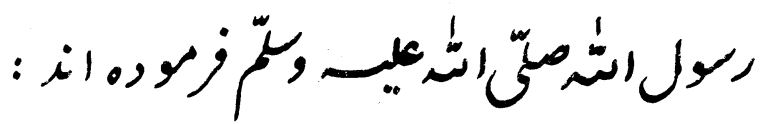

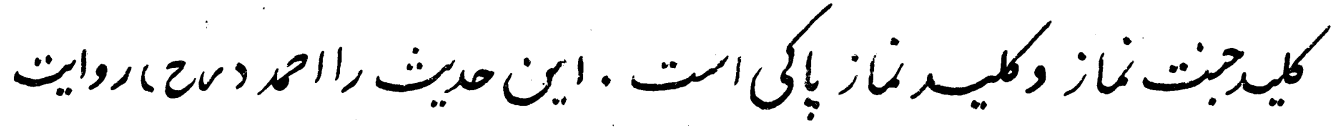

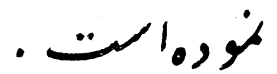

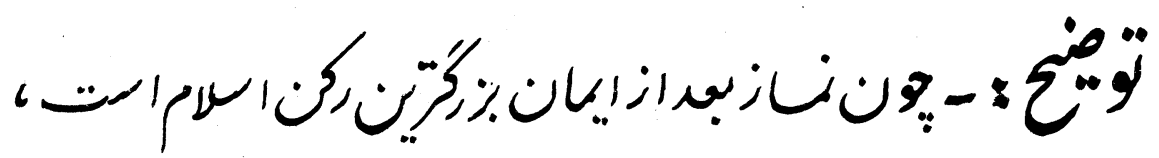

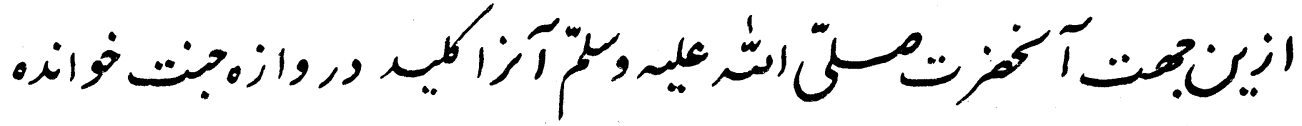

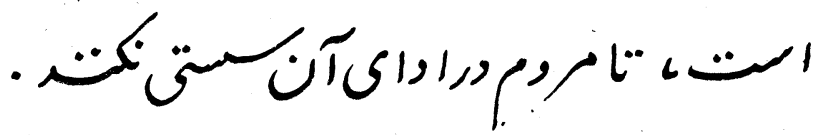

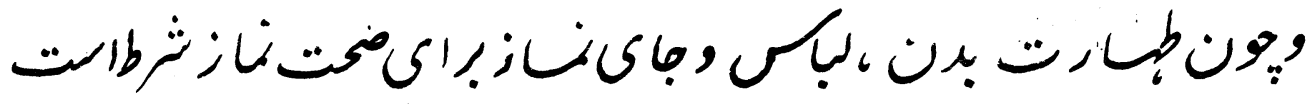

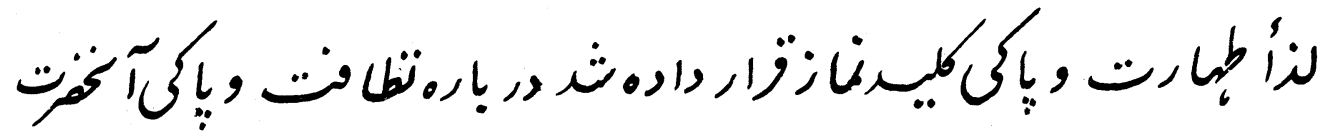

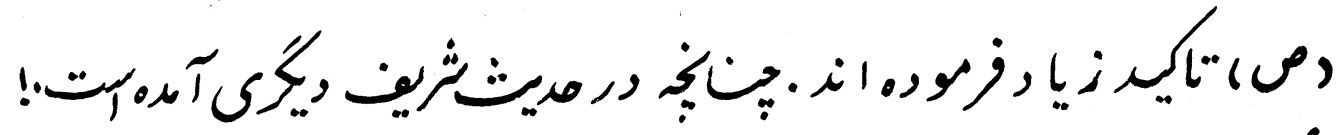

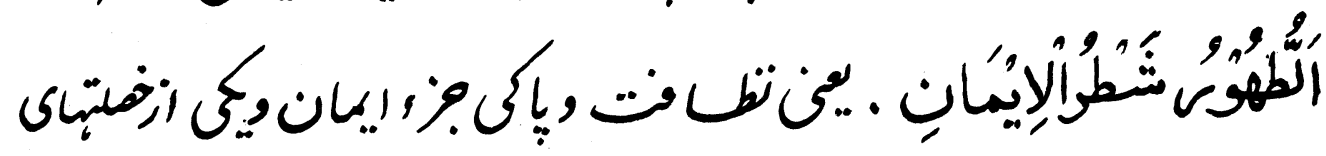

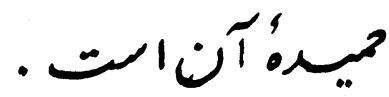




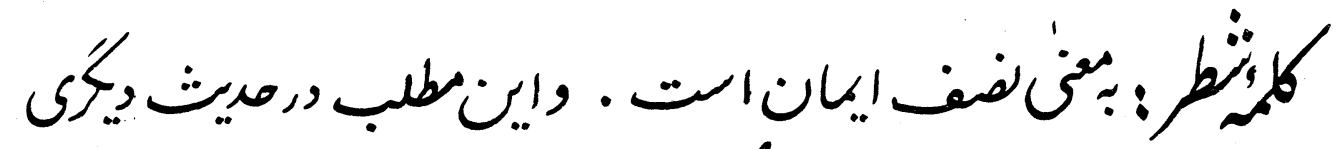

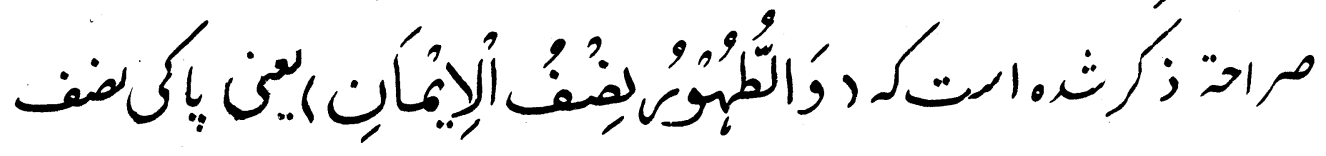
إيكانامت

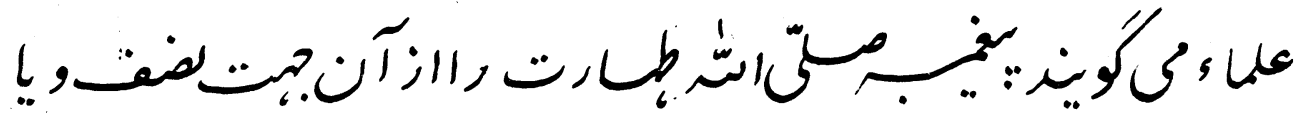

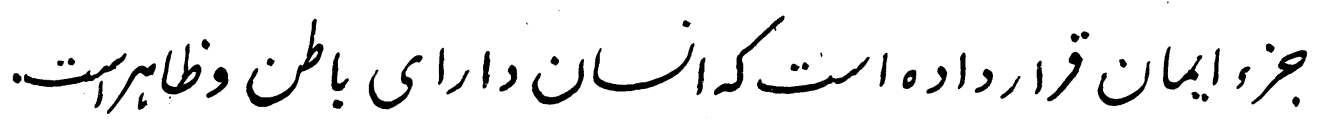

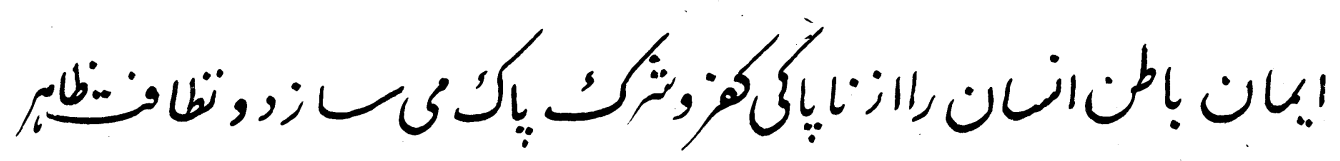

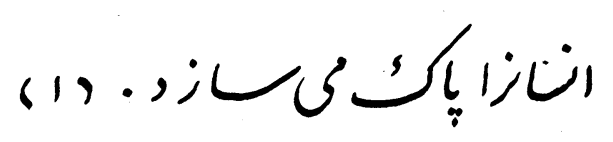

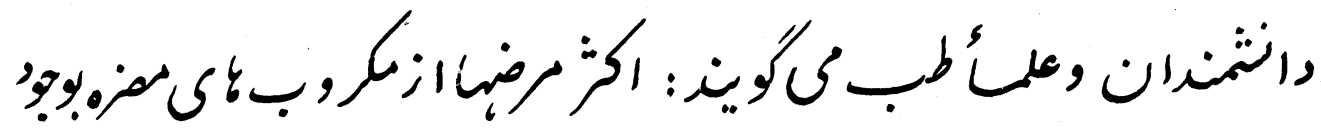

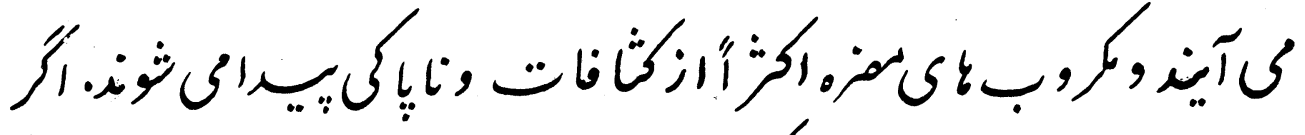

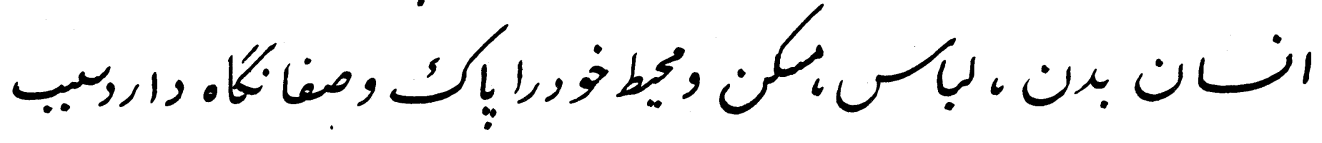

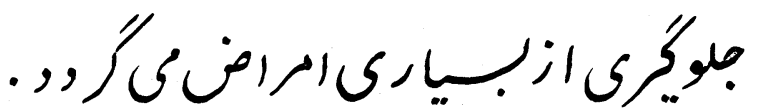

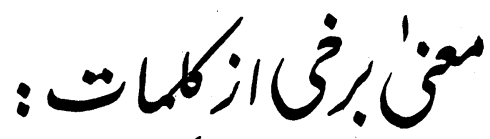

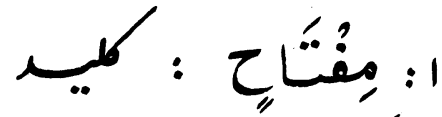

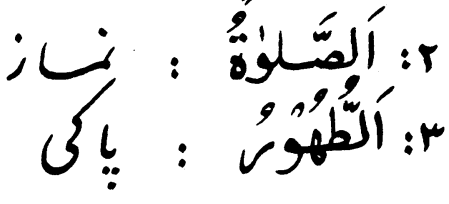


$\int_{0}^{\infty}$

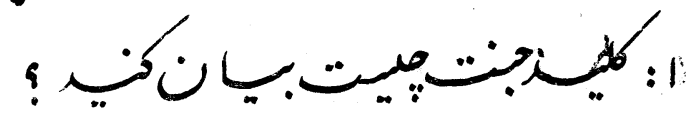

ז: كليسن

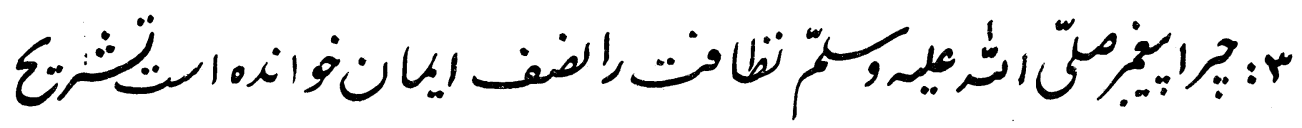

نَيد؟

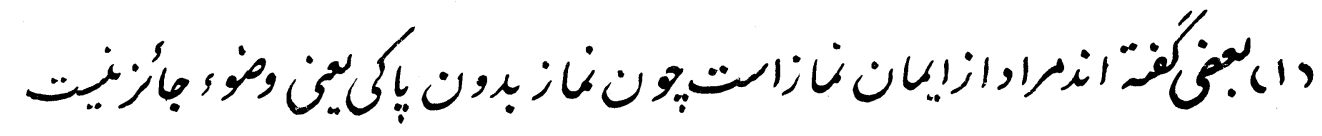

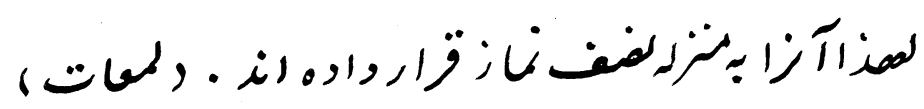

ry 


\section{ن}

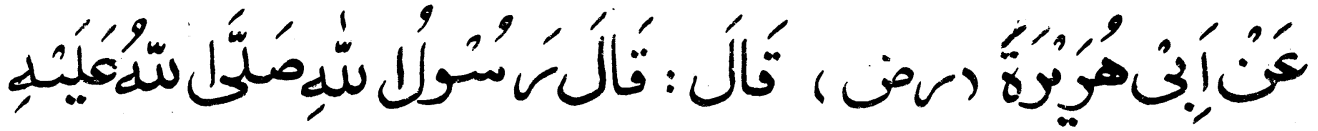

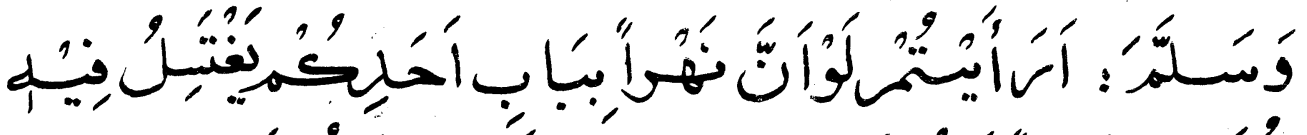

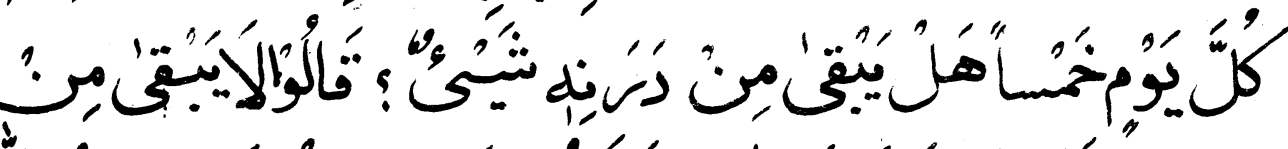

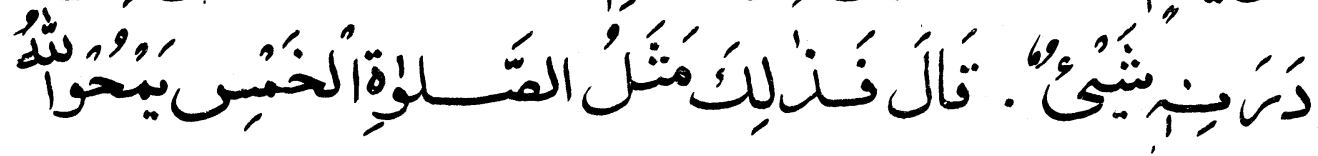

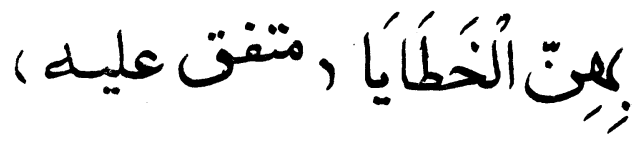

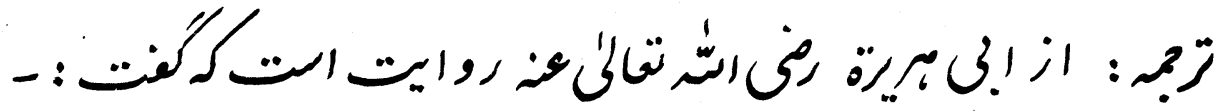

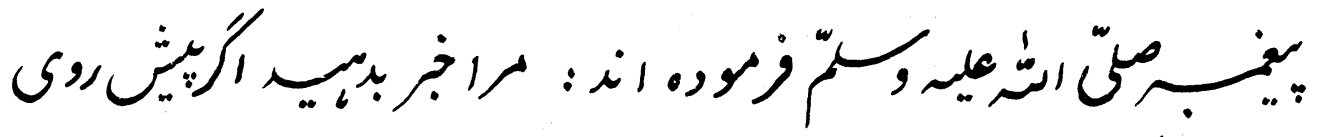

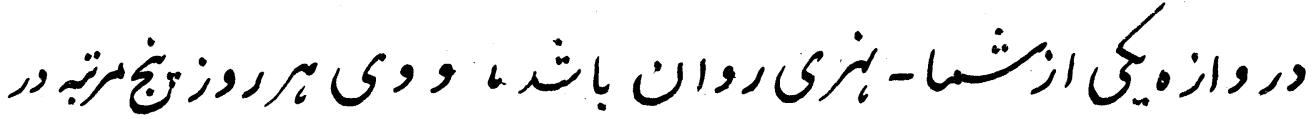

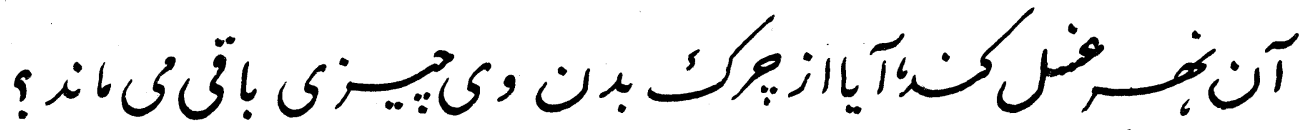

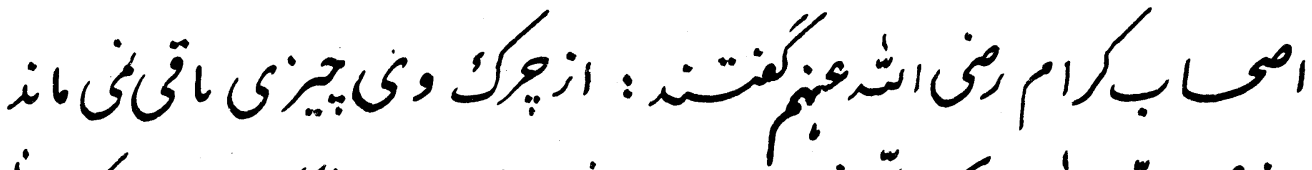

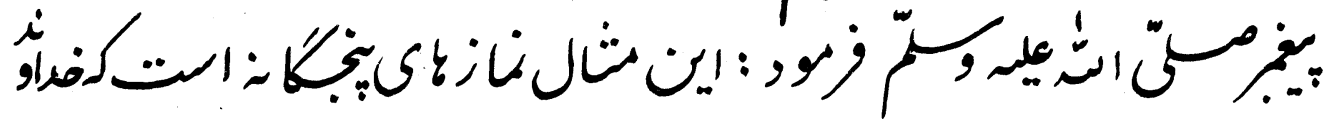

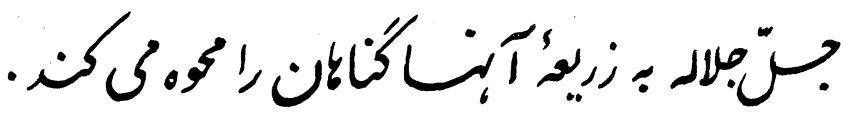




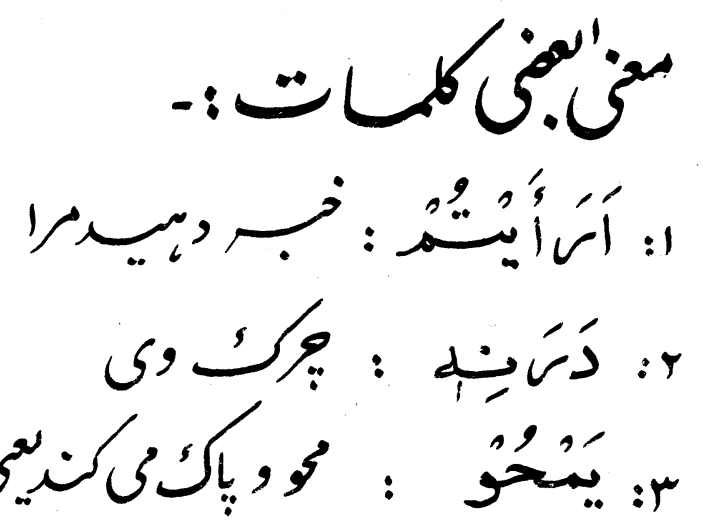

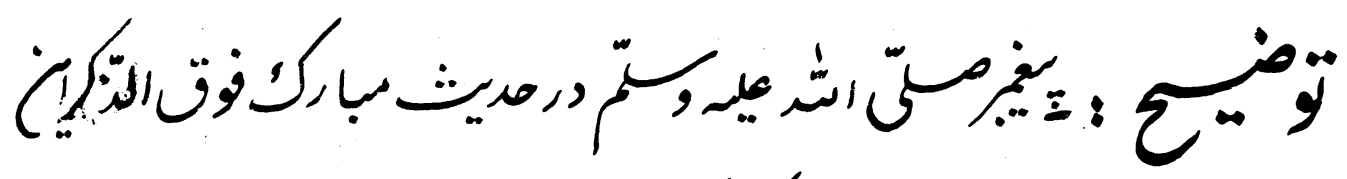

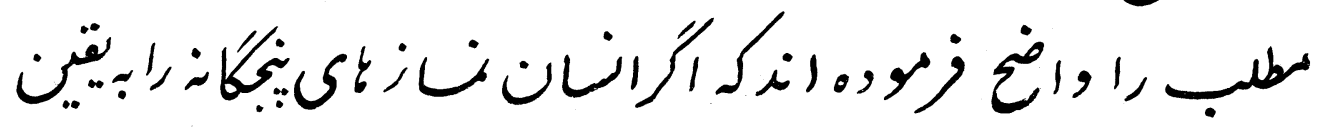

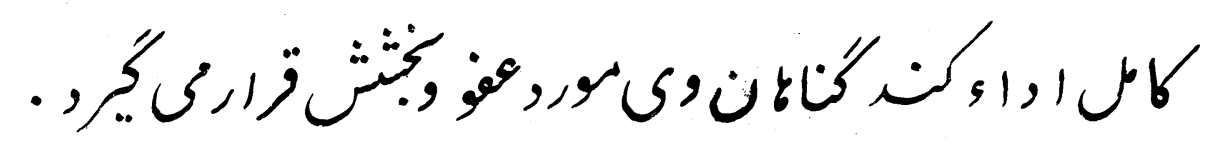

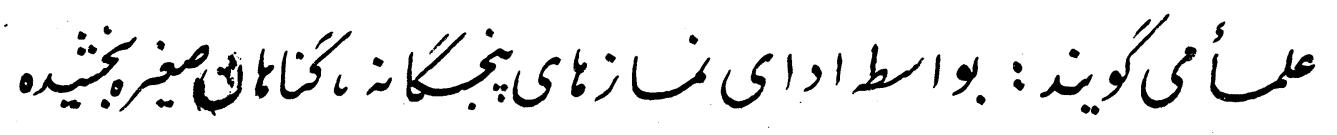

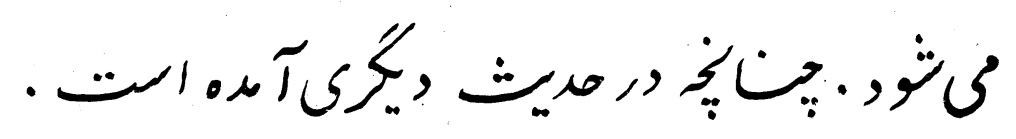

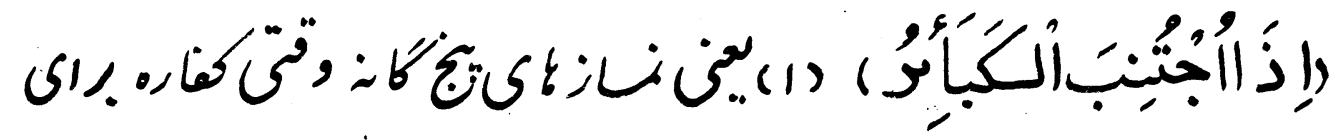

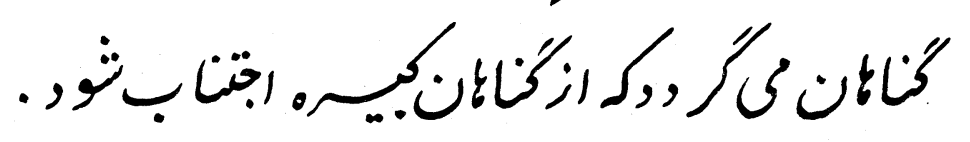

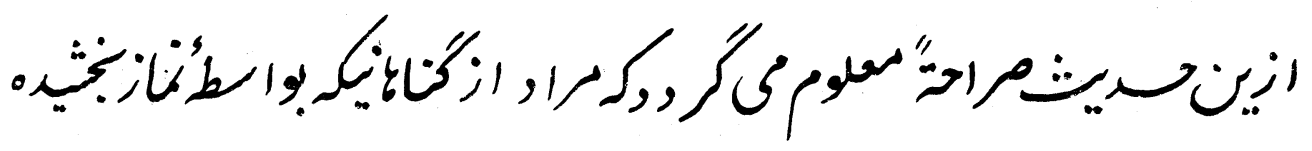

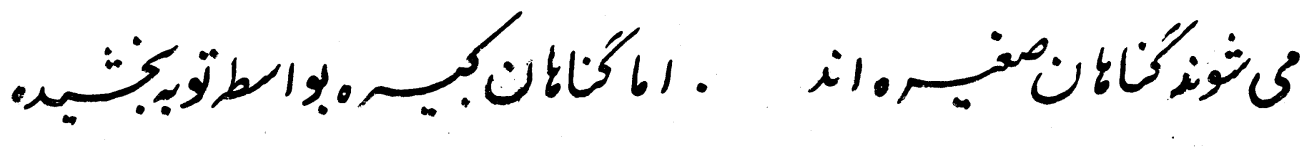

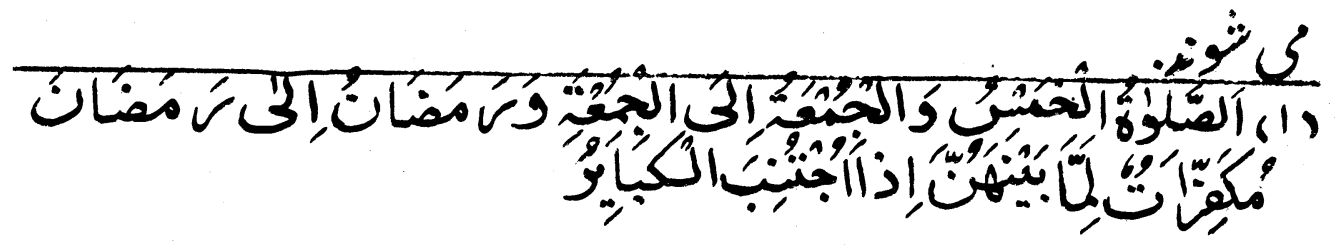

$$
\begin{aligned}
& \text { ro }
\end{aligned}
$$


(

is:b

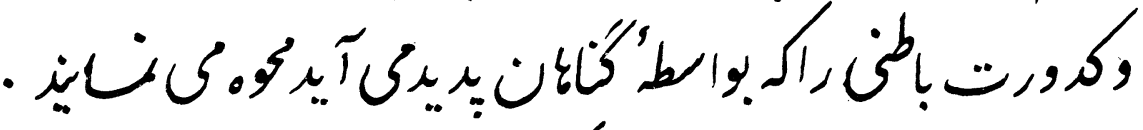
:

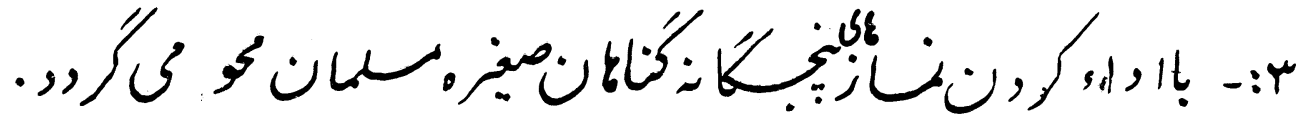
(

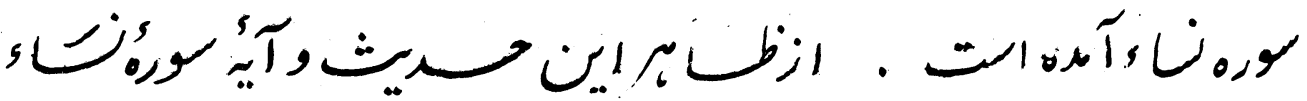
:

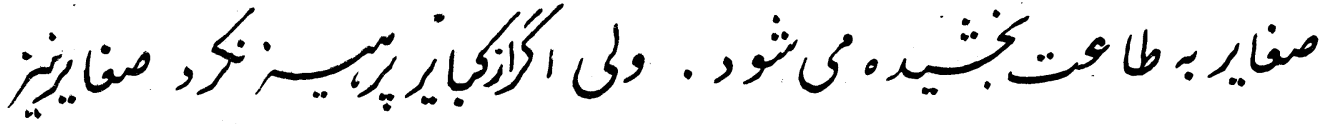

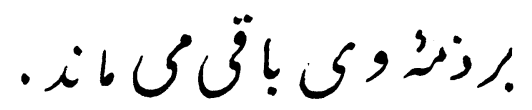

ا 1 is

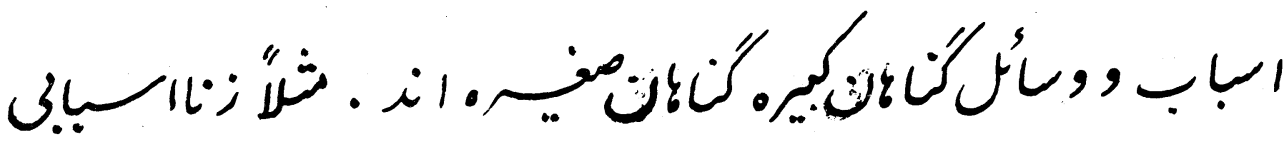

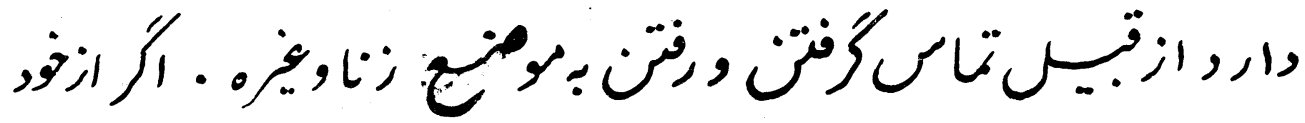




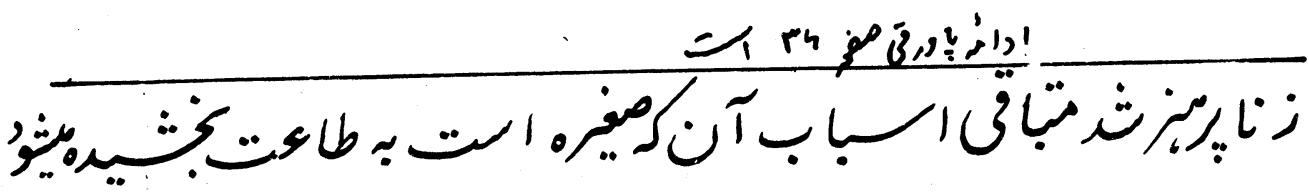

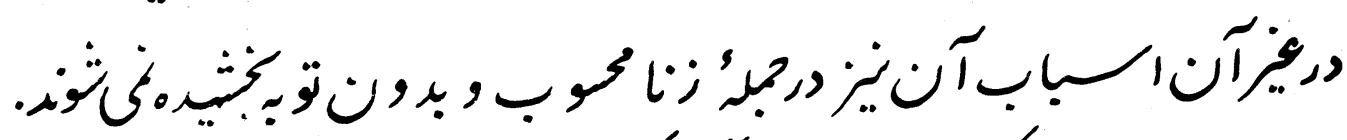

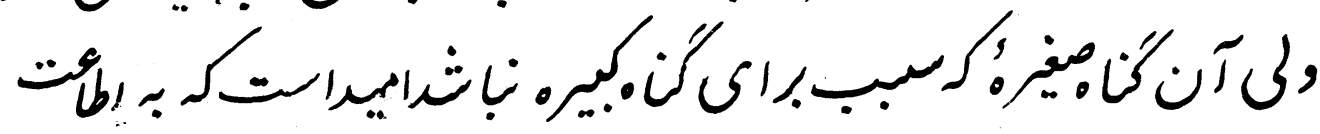

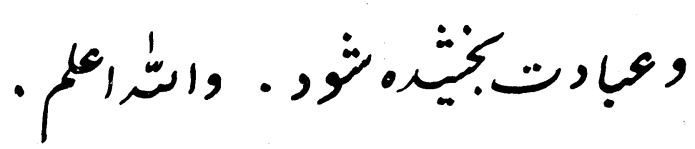

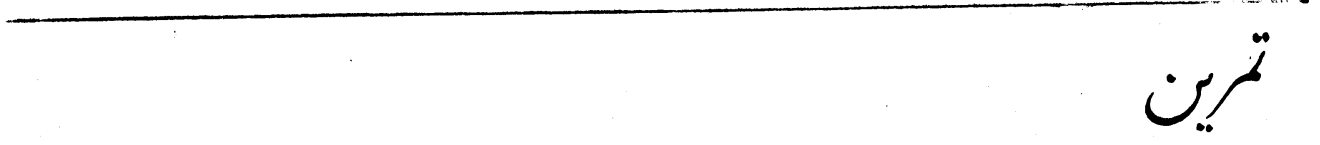

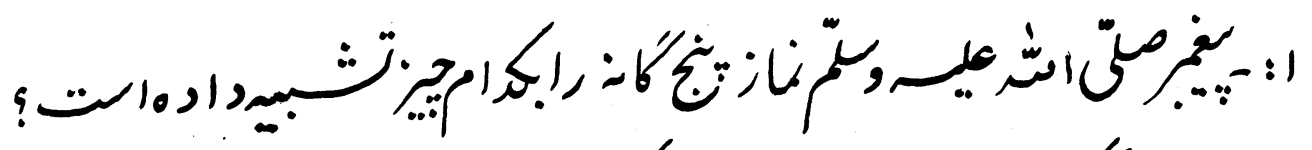

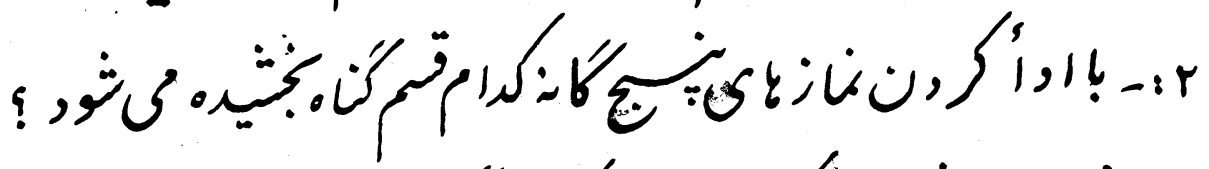

r 


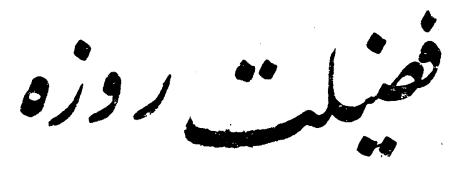

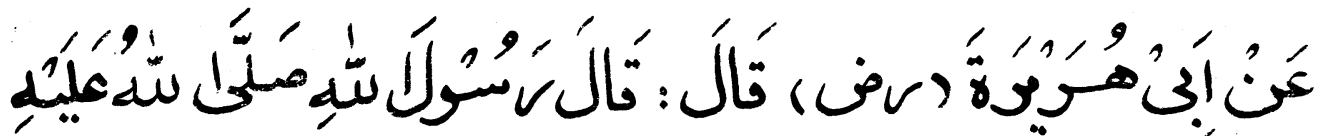

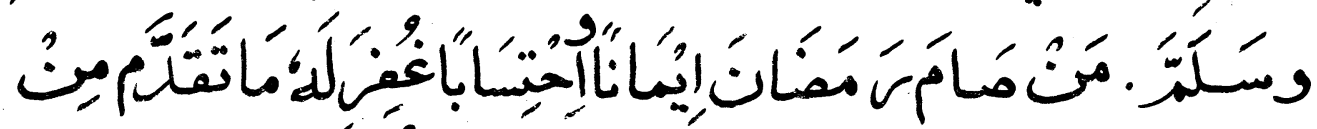

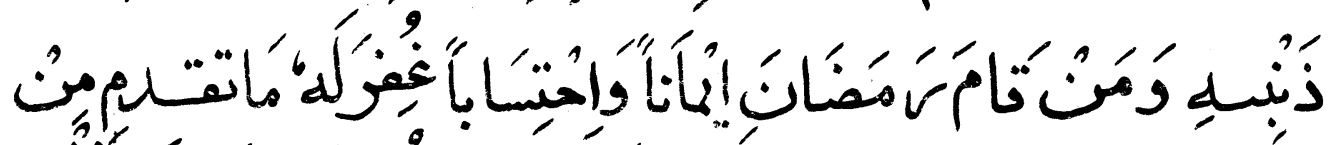

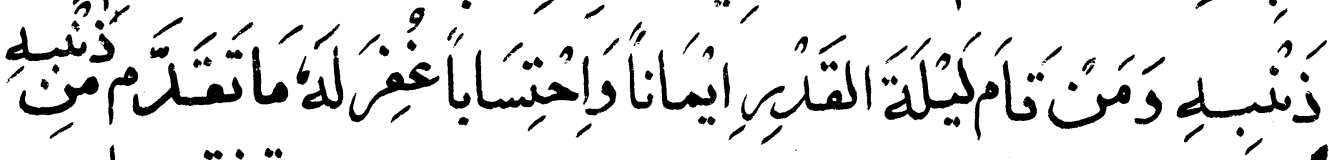

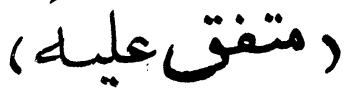

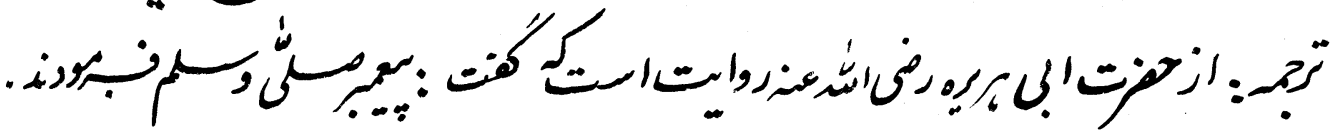

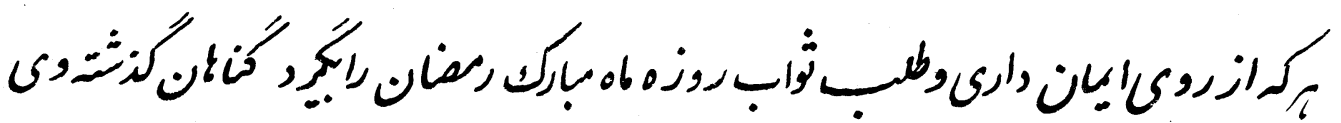

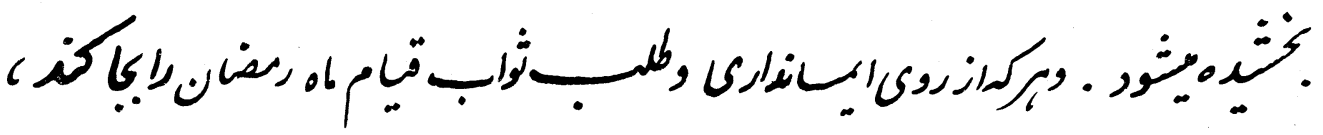

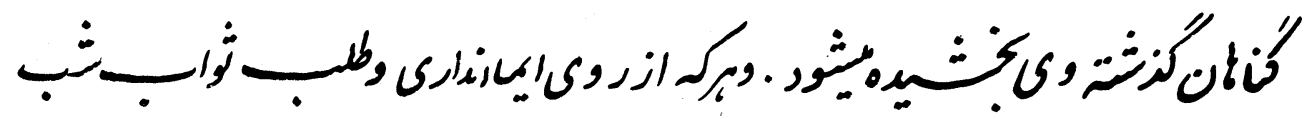

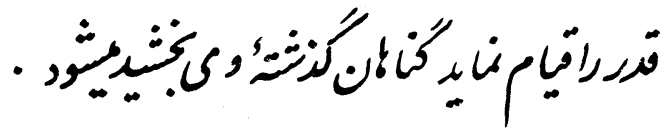

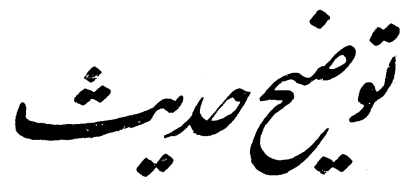

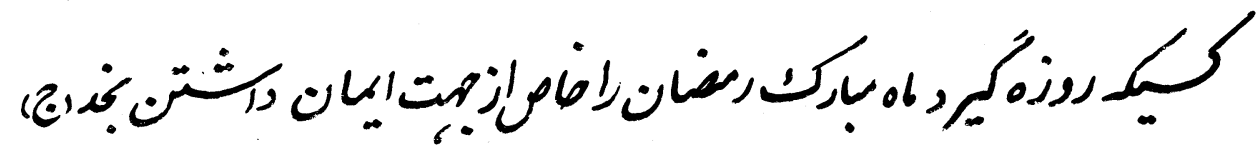

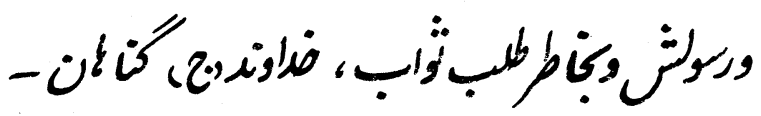

rA 


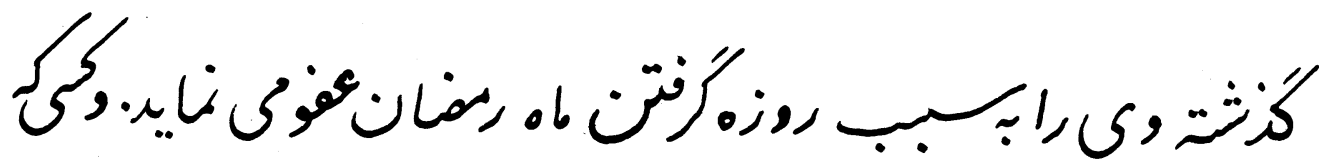

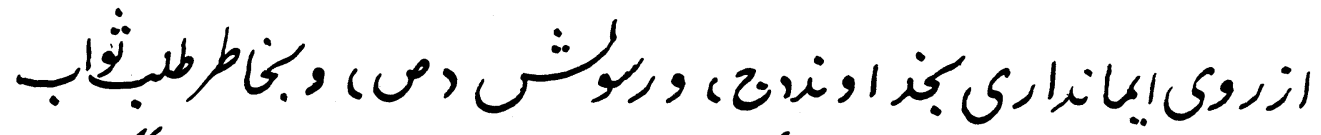

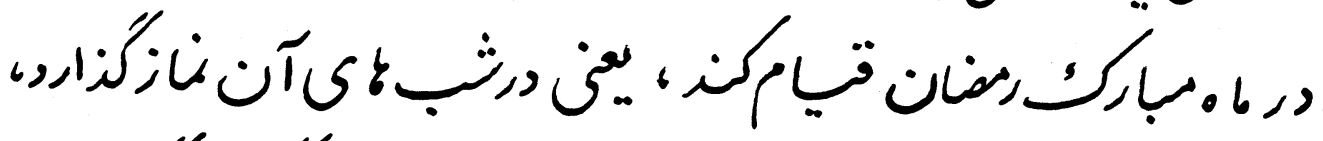

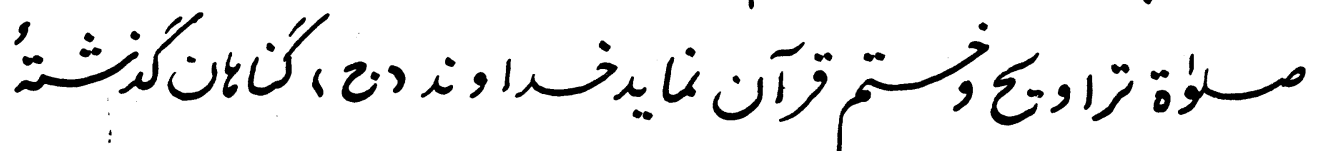

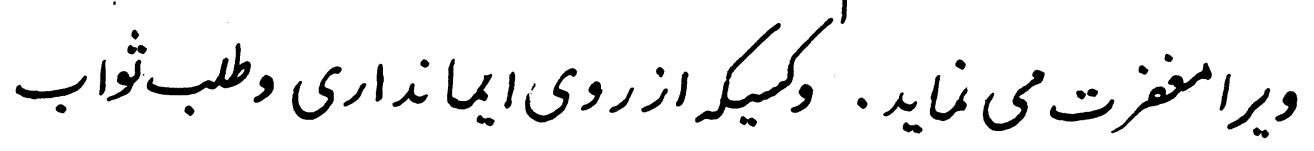

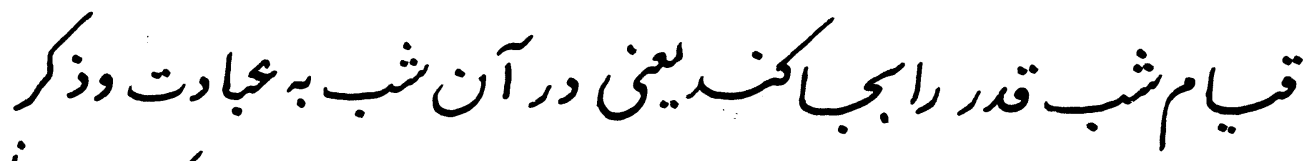

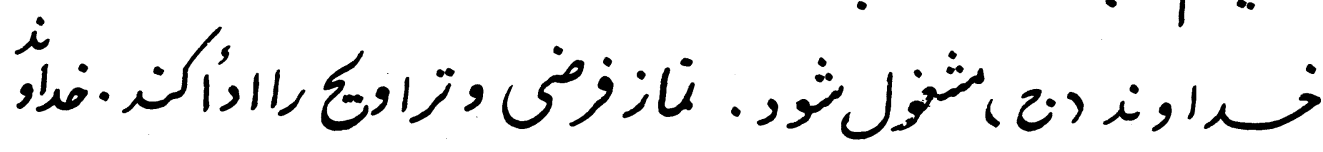

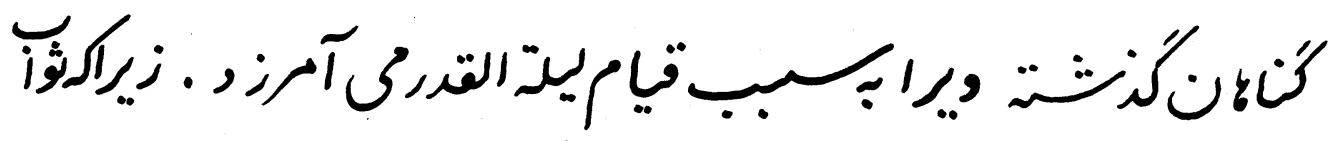

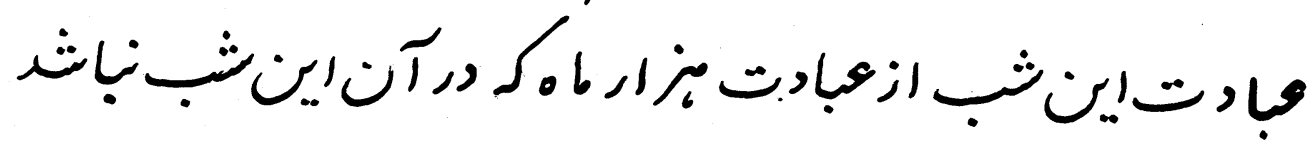

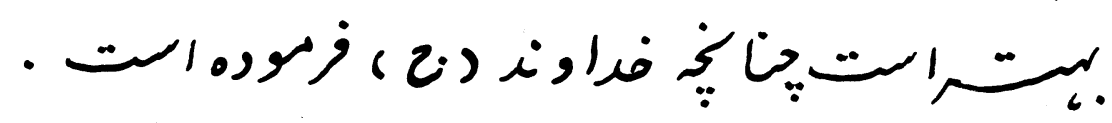

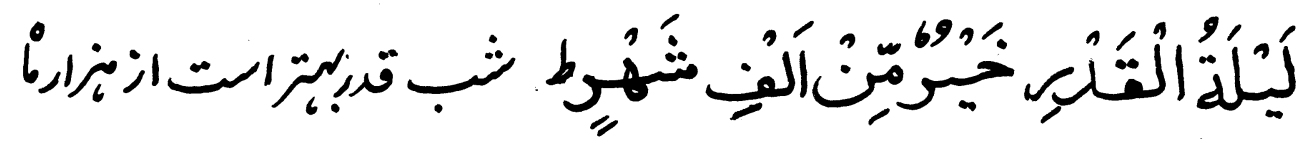

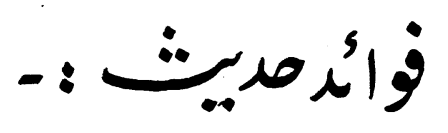

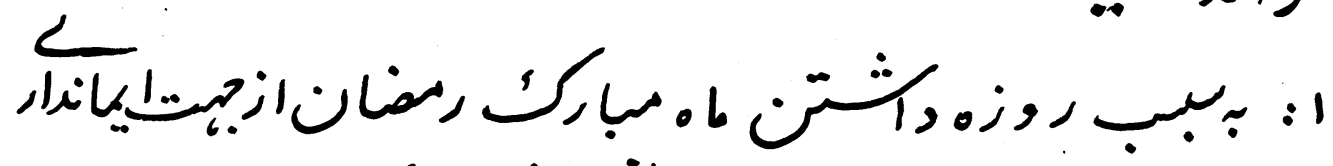

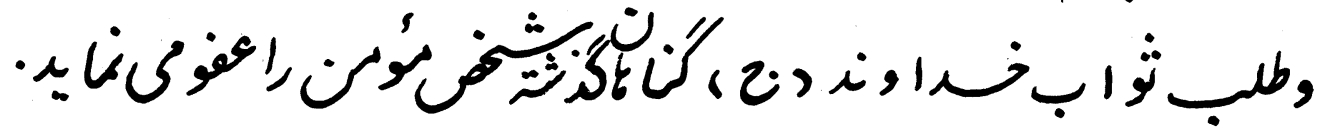

rq 


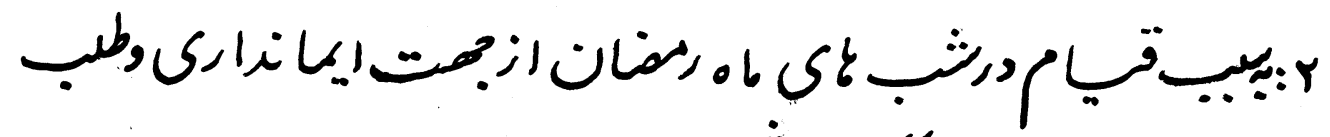

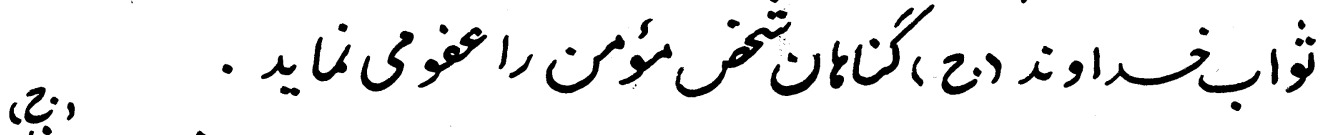

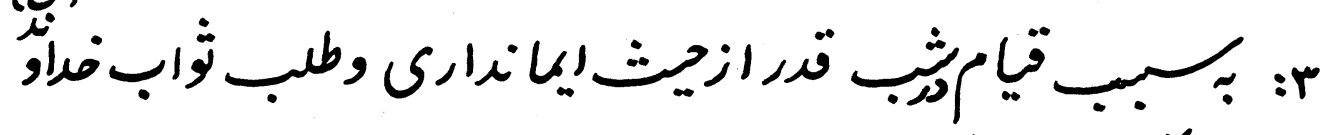

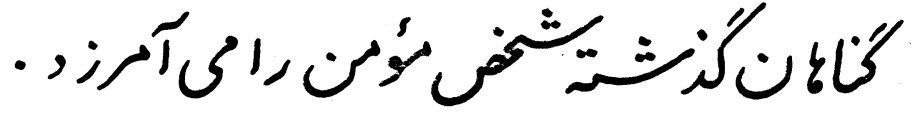

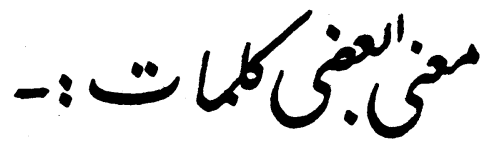

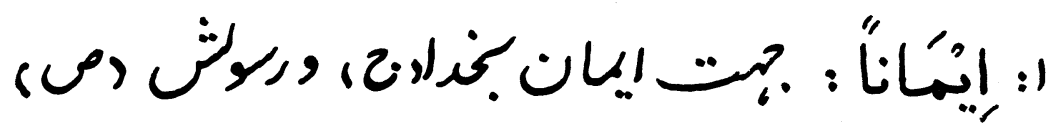

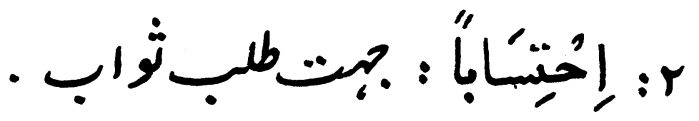

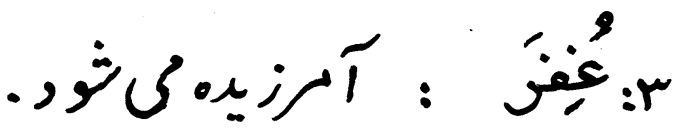

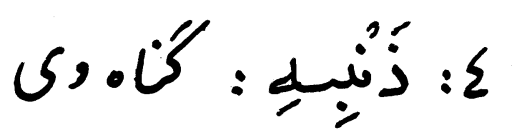

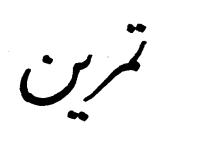

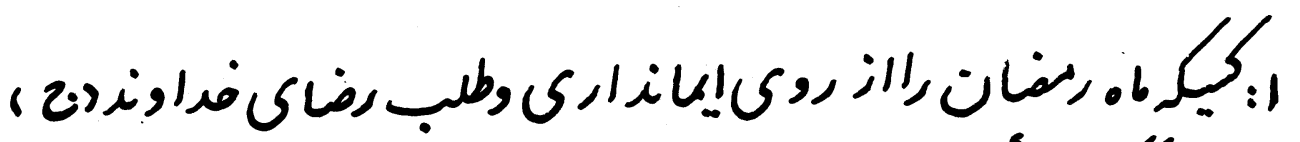

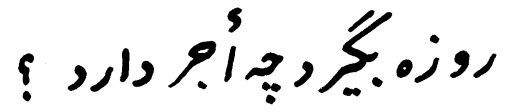

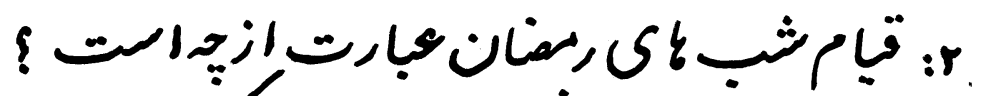

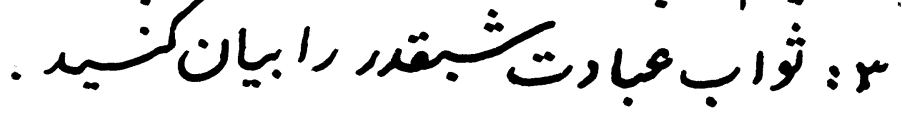


ت

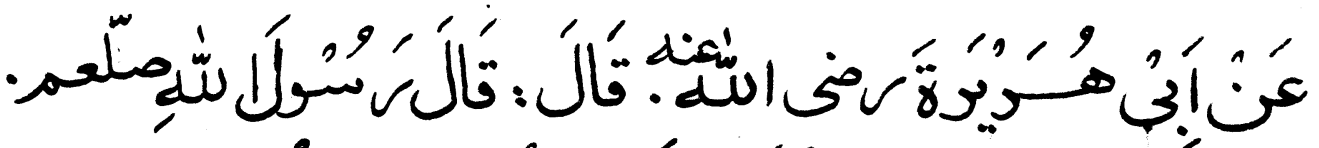

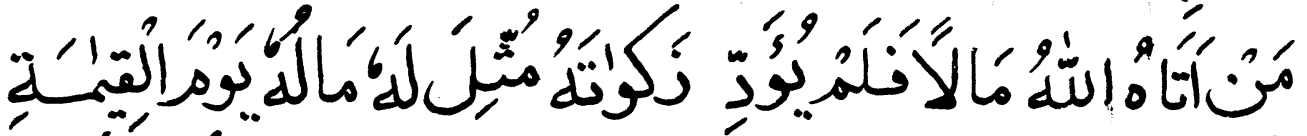

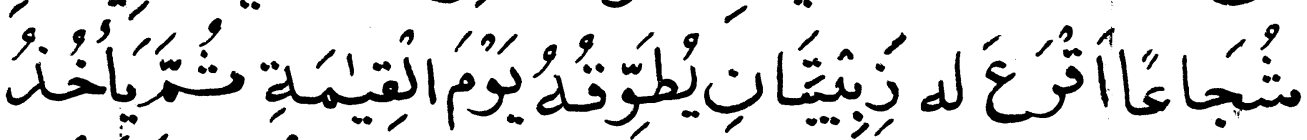

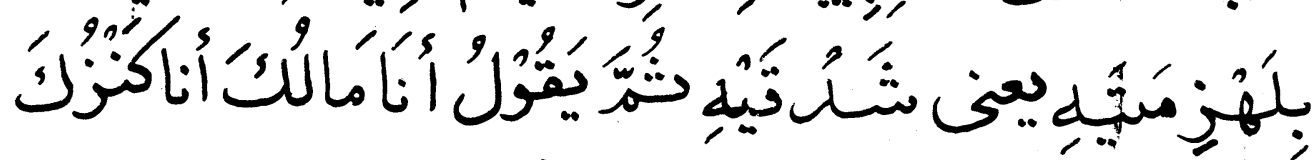

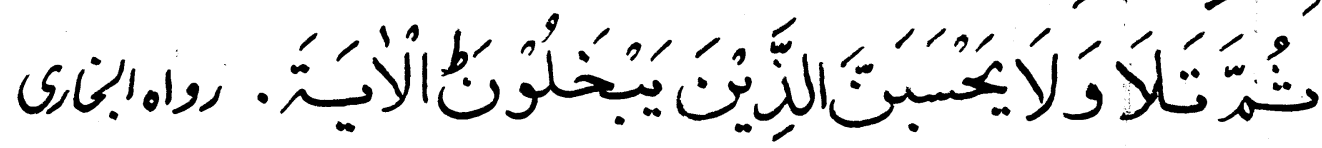

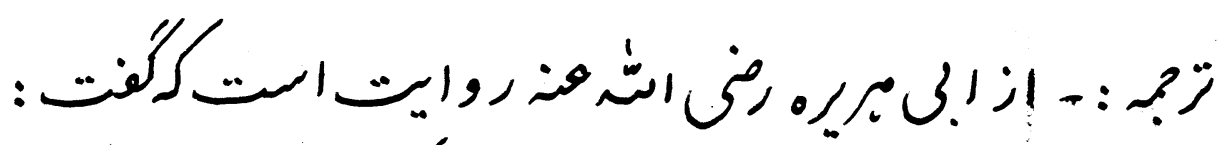

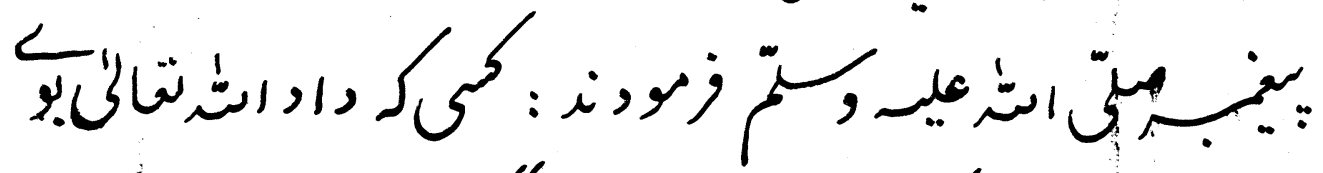

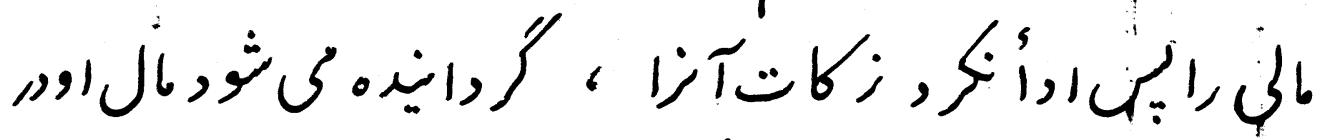

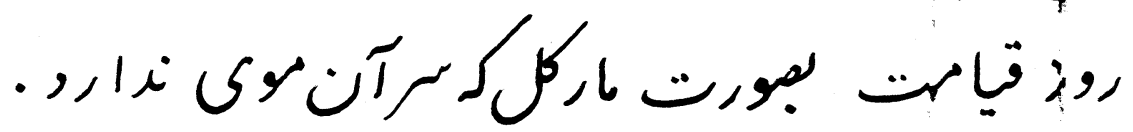

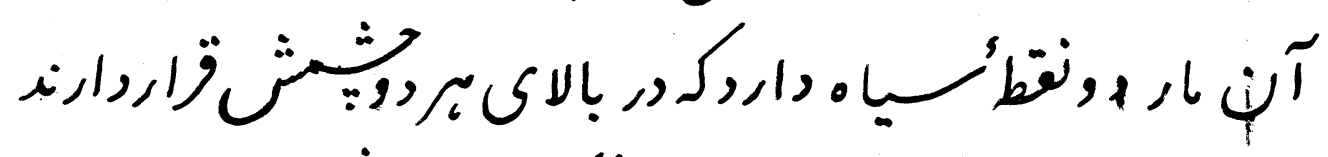
كرانيده

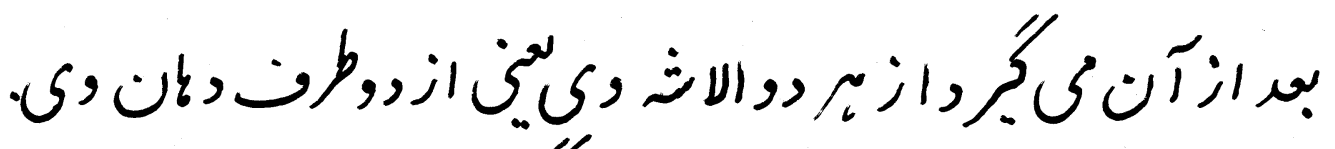

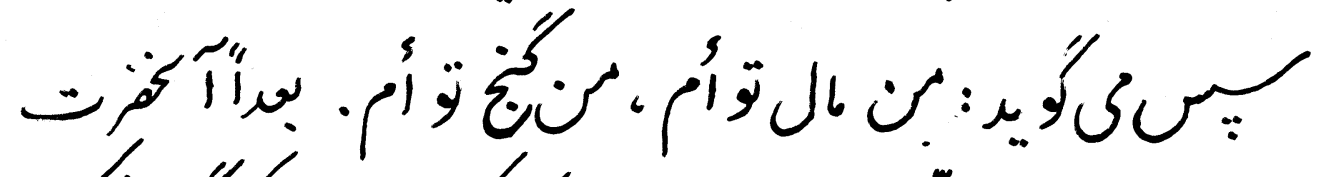

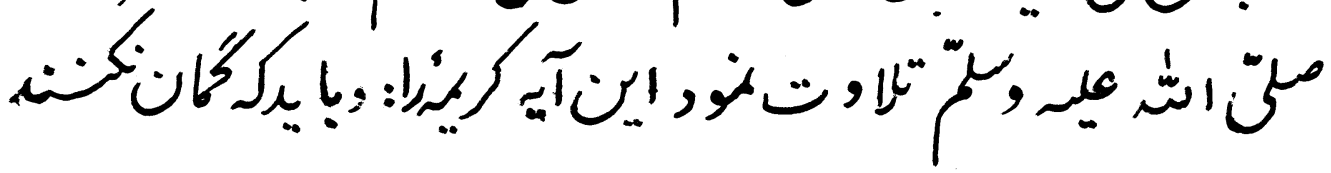
fi 


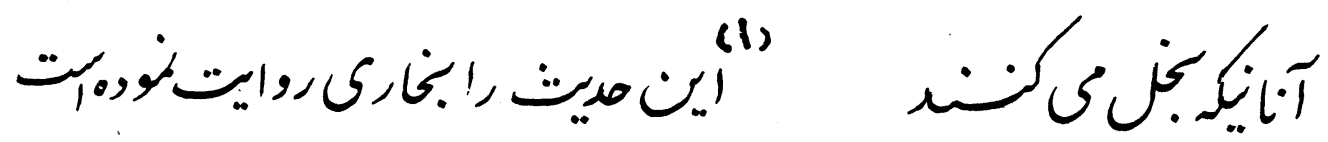

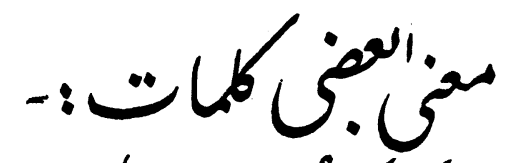

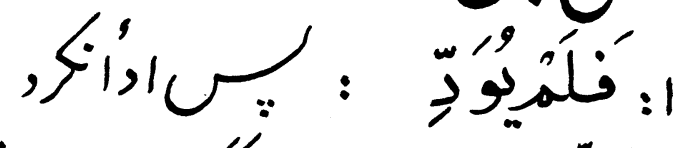

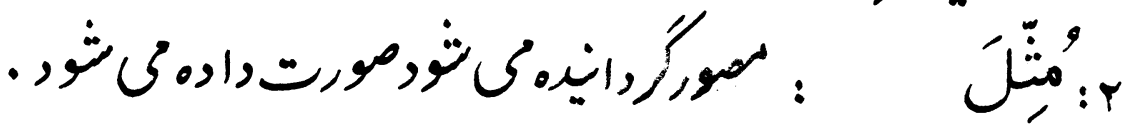

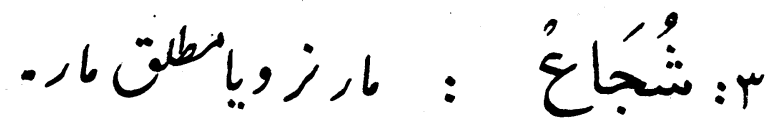

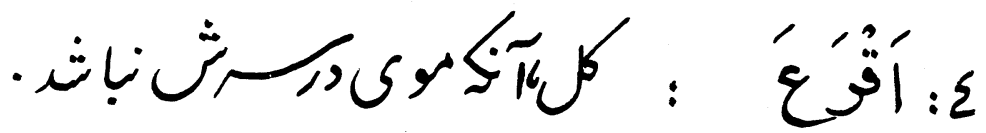

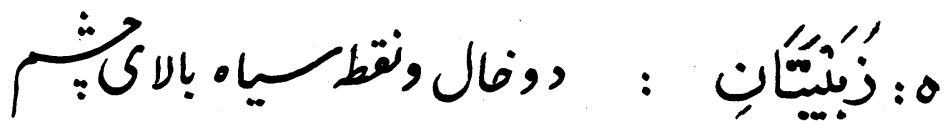

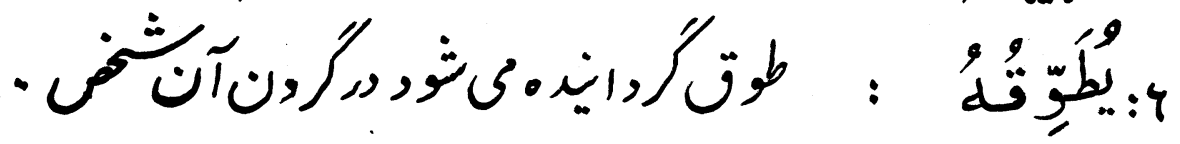

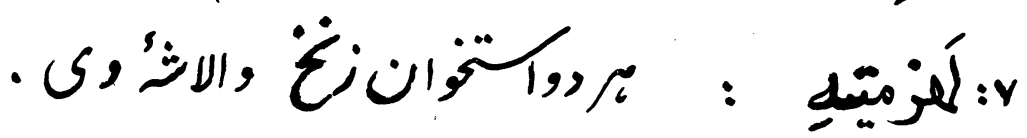

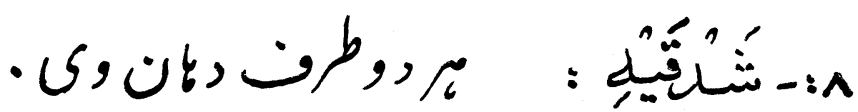

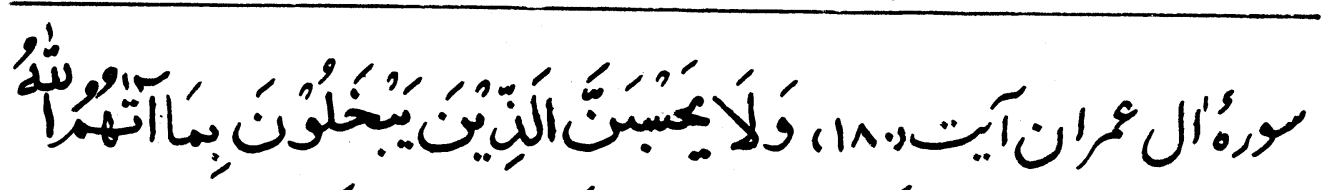

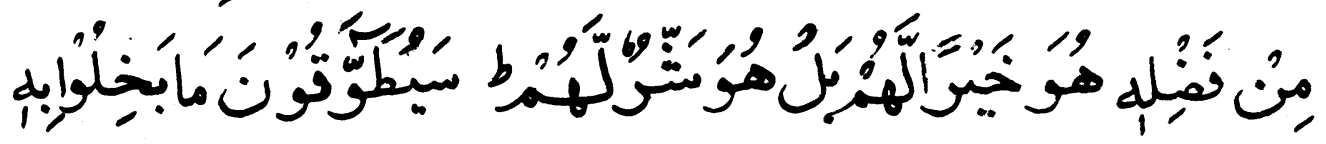

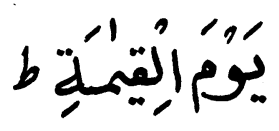




$$
-: 0 \ddot{\nu}
$$

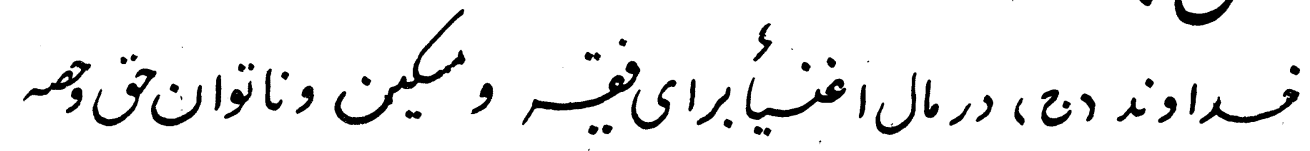

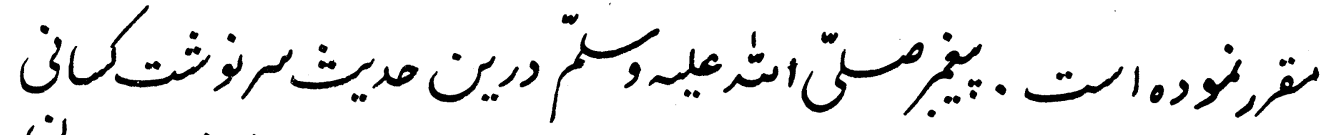

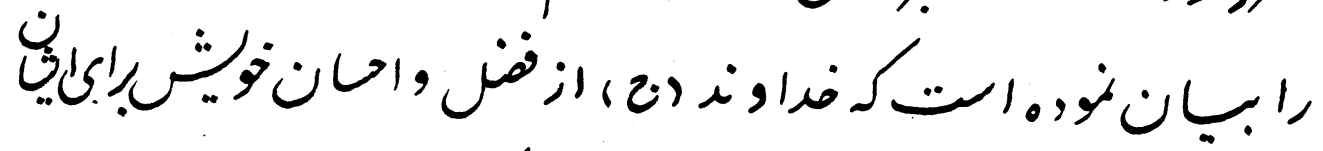

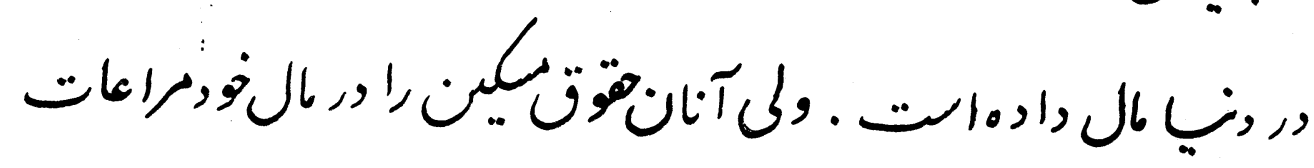

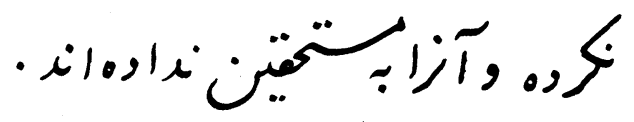

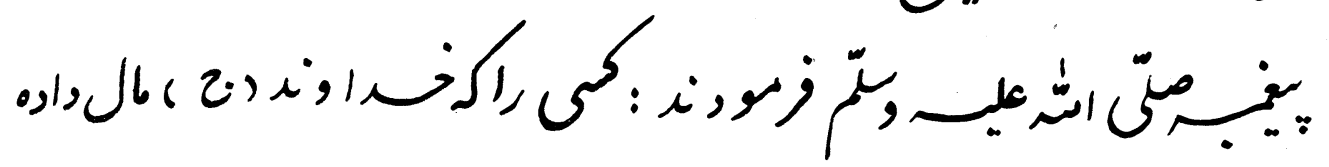

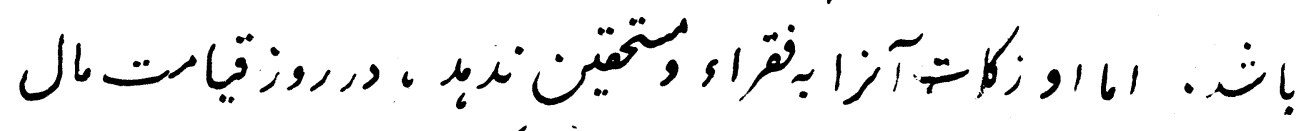

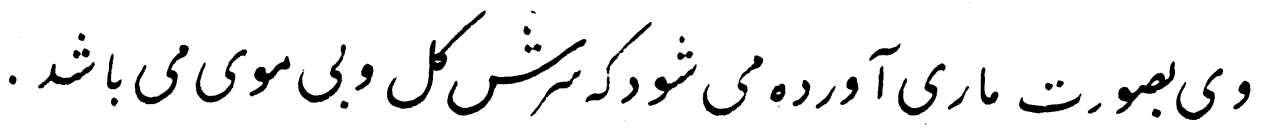

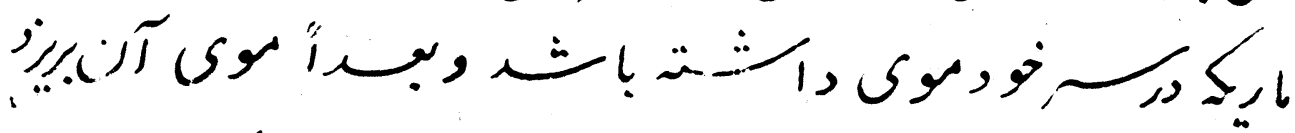

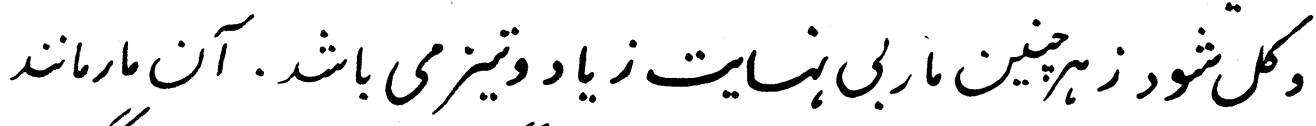

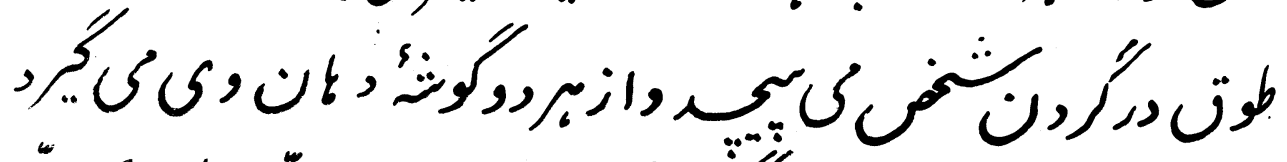

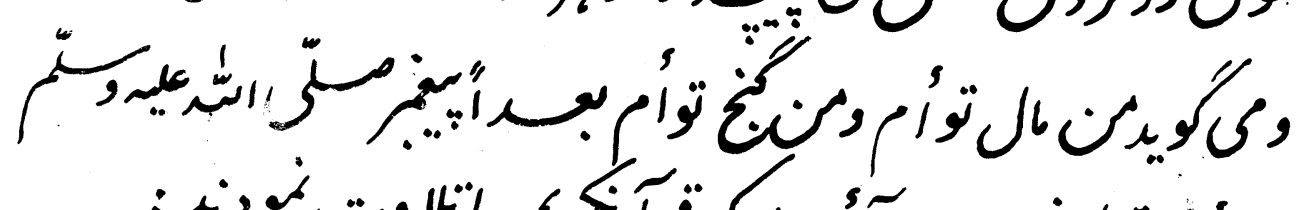

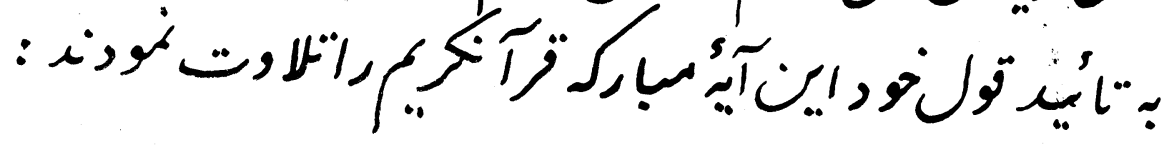

er 


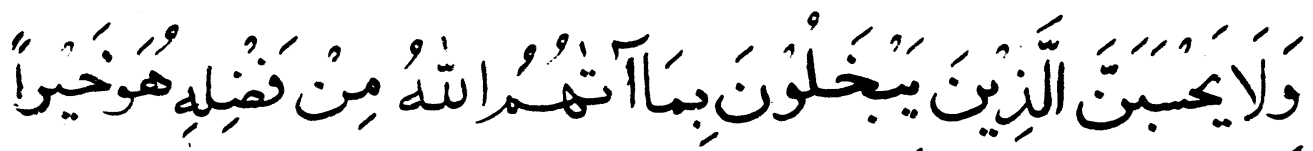

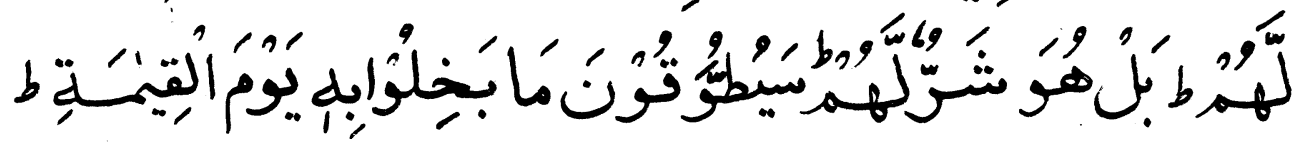

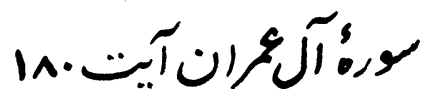

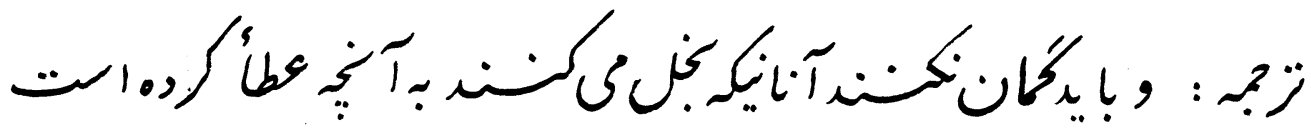

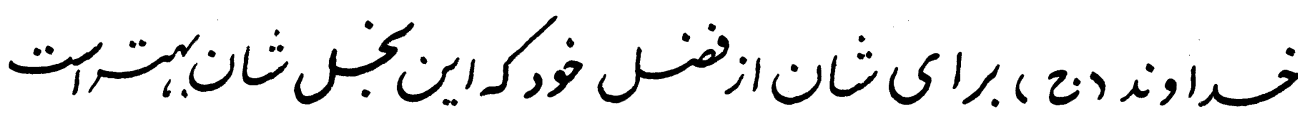

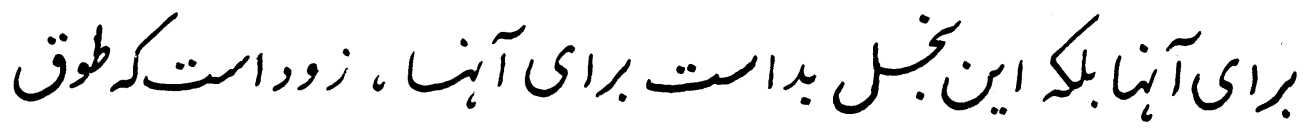

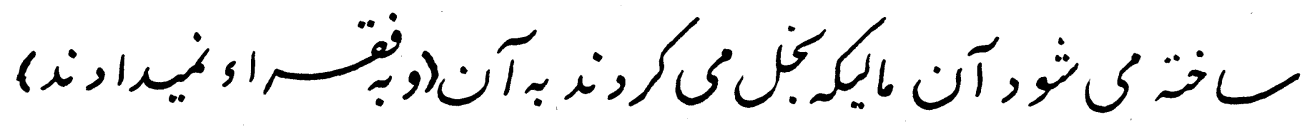

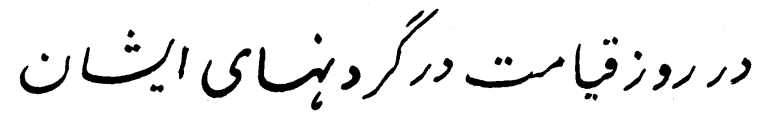

$$
\text { مَّ人 }
$$

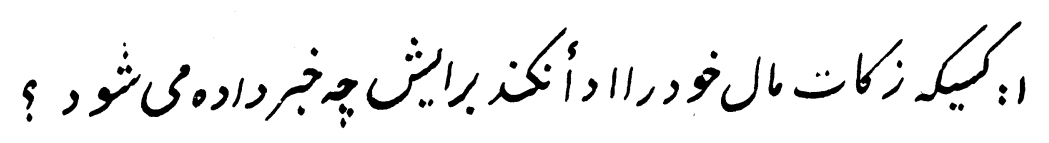

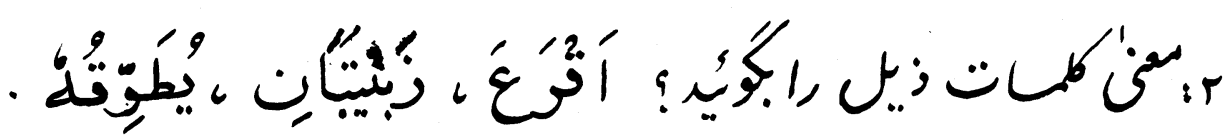

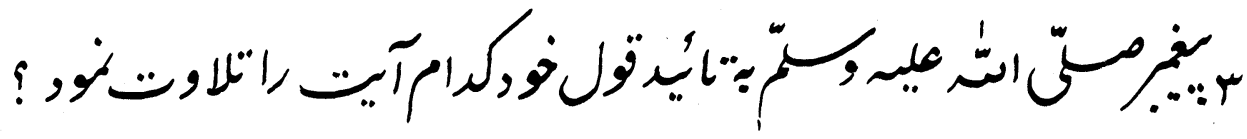

ft 


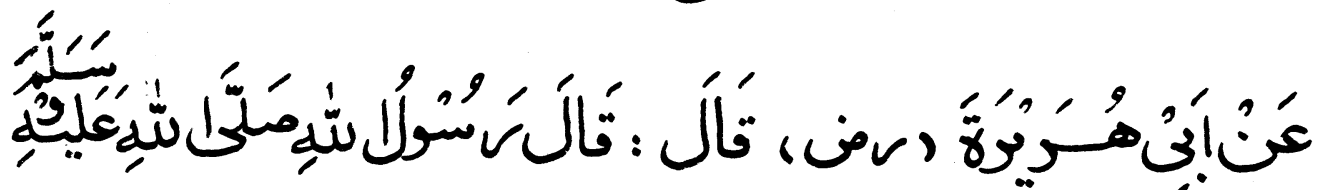

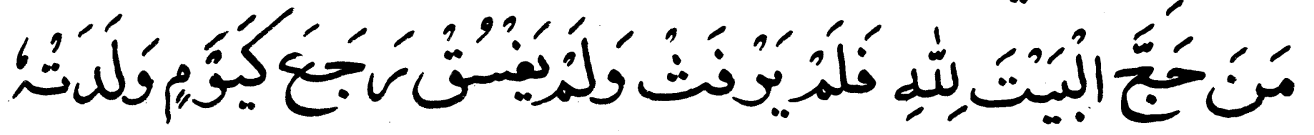

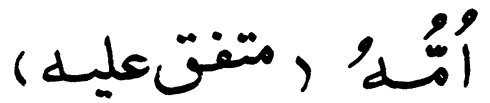

קיק:

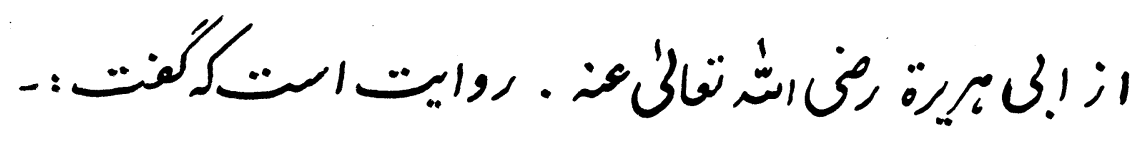

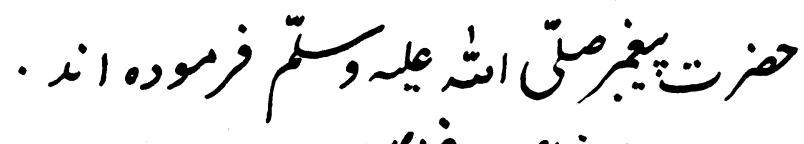

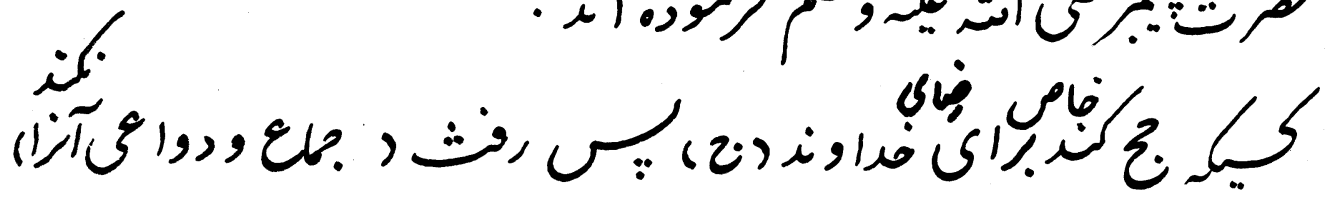

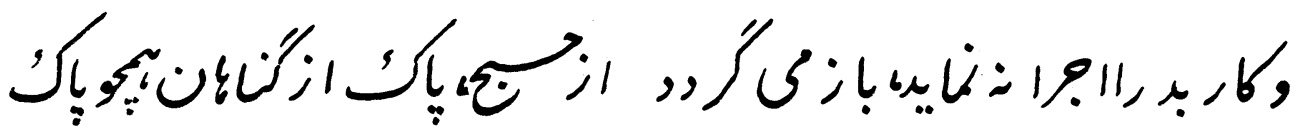

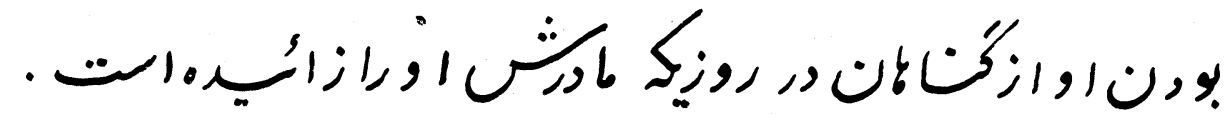

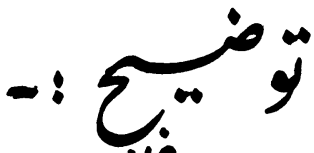

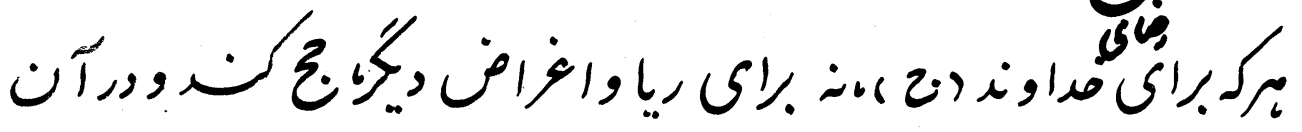

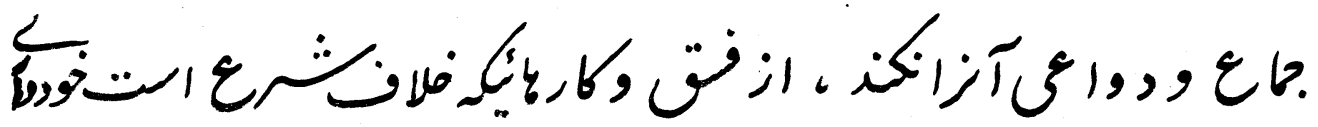

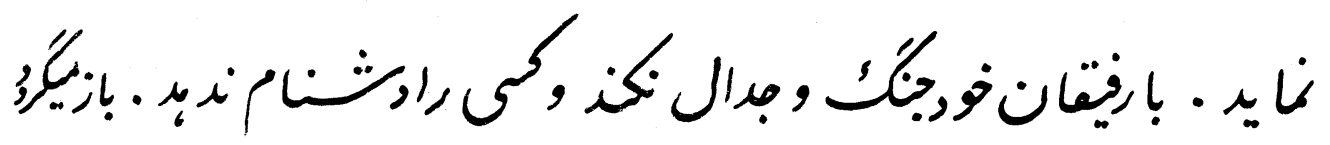

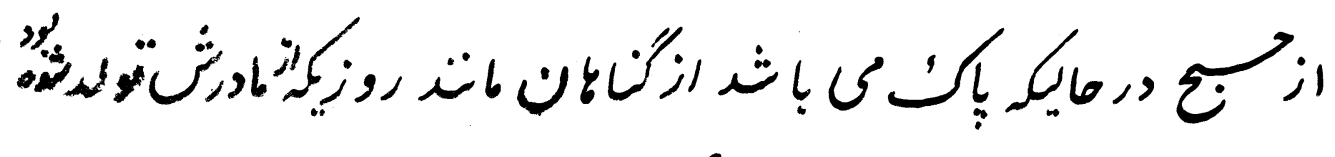

fo 


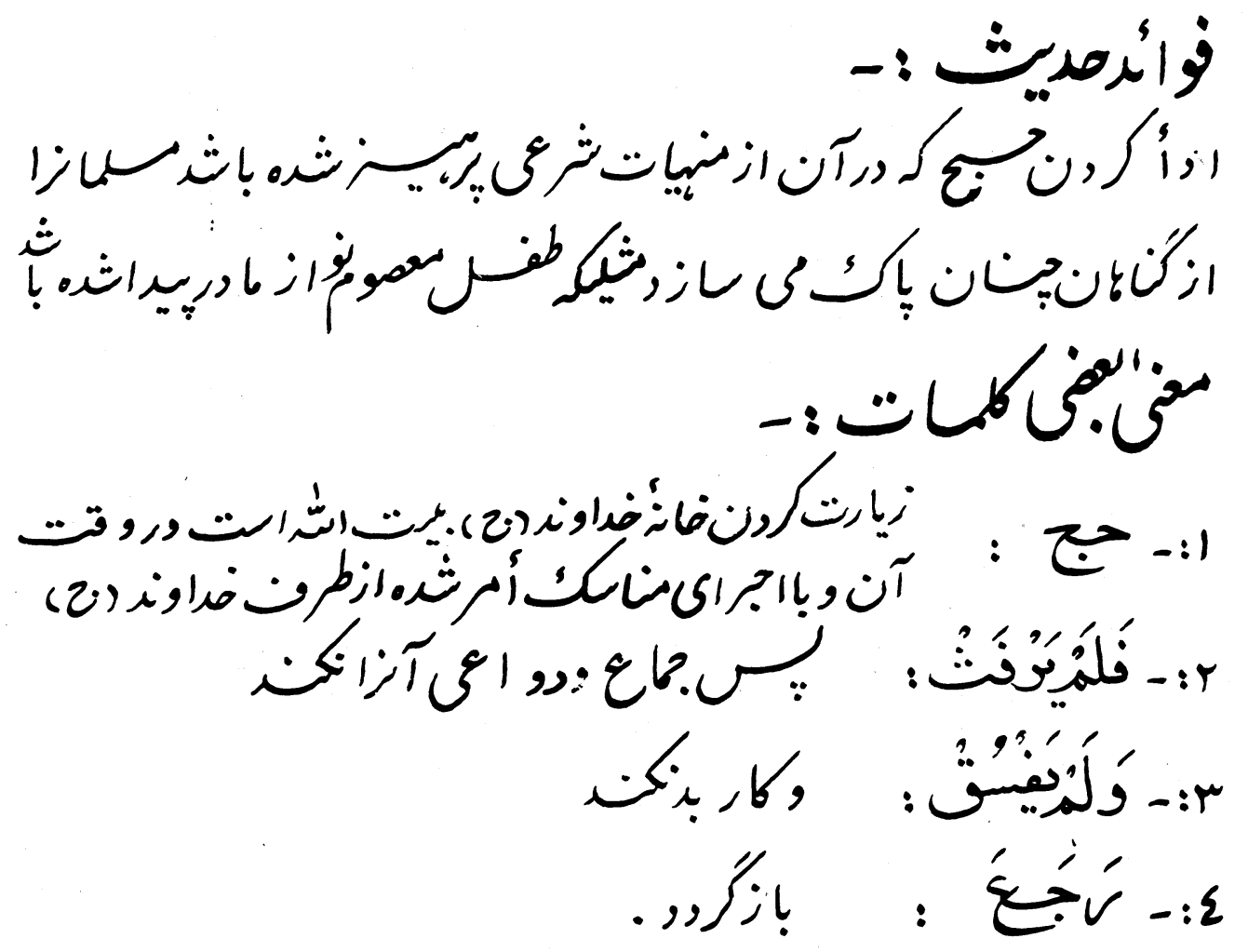




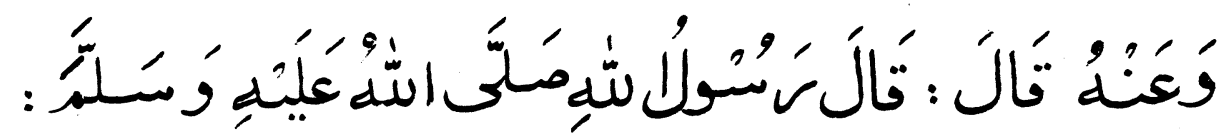

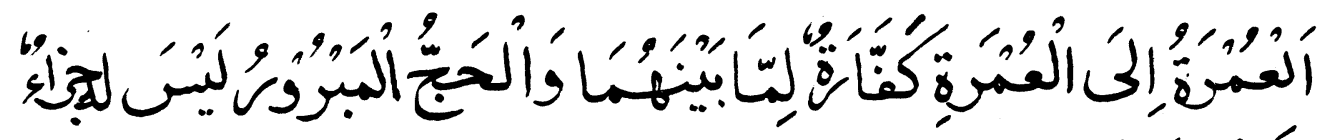

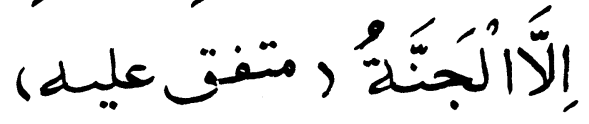

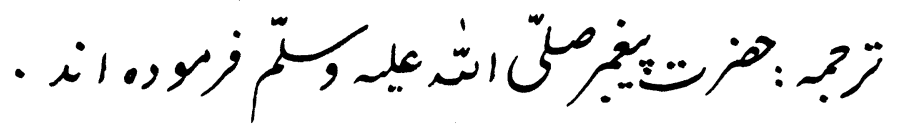

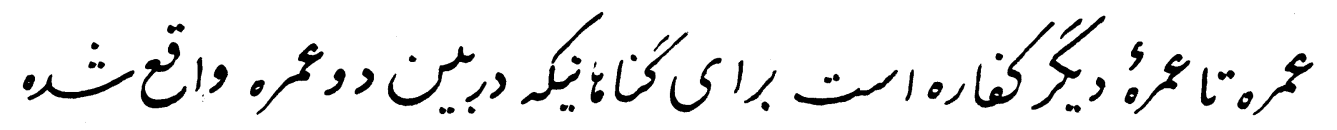

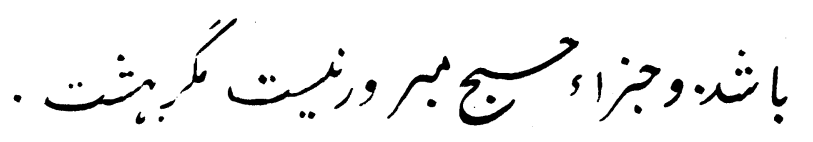

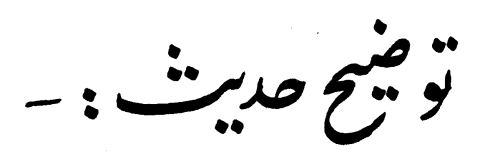
وره ورلنت بمناى زيارته

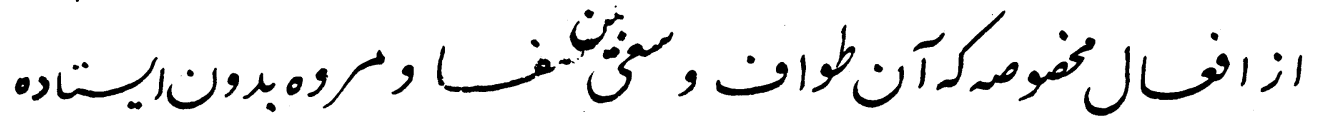

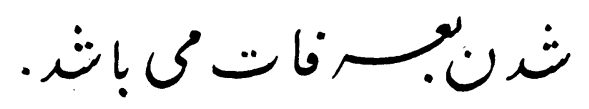

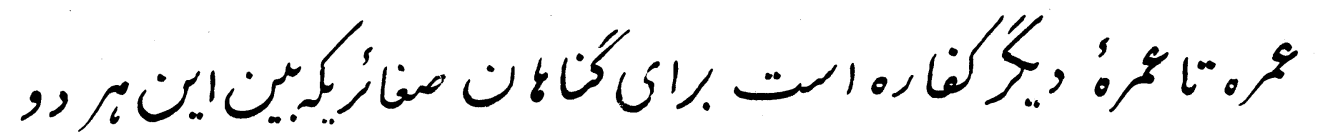

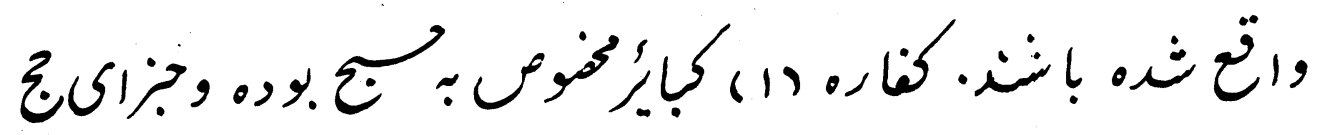

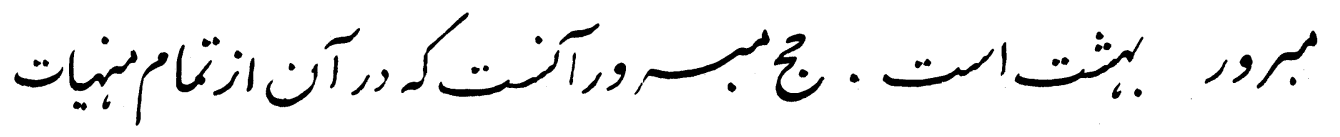

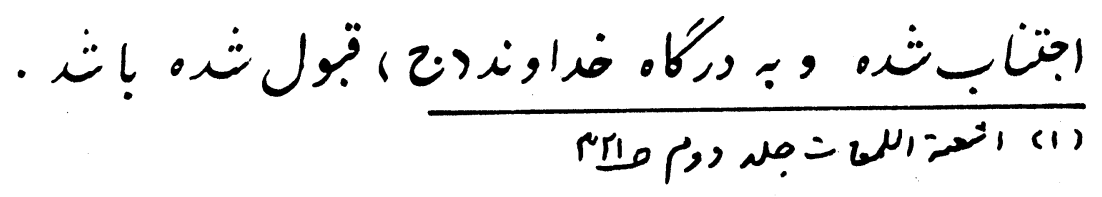


$\ddot{f}$

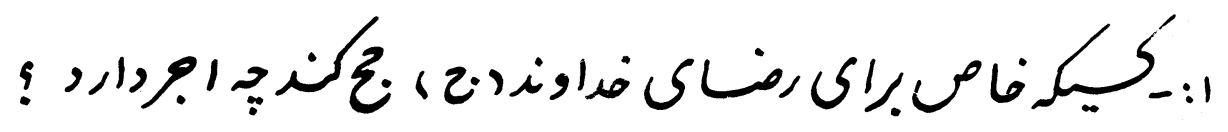

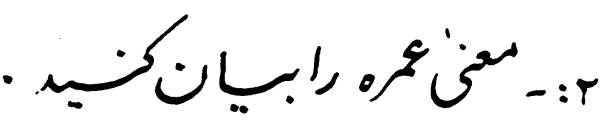

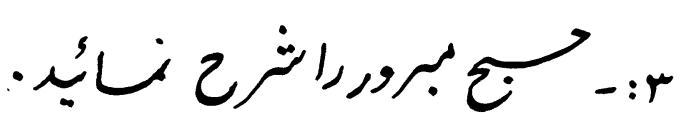

fA 


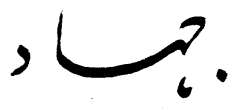

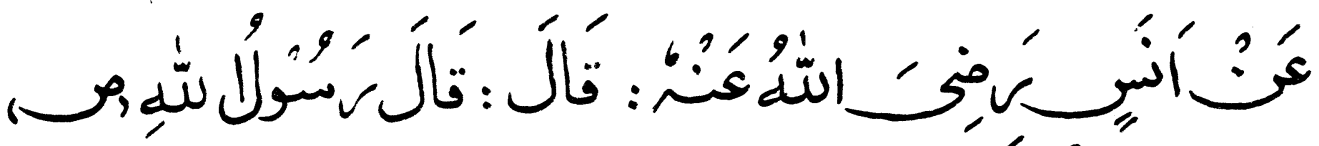

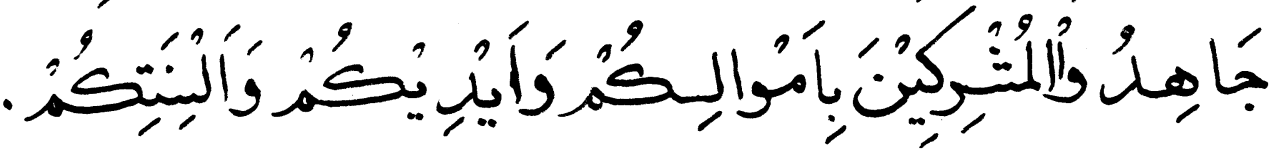
رواه احم و ابو راور ونَن .

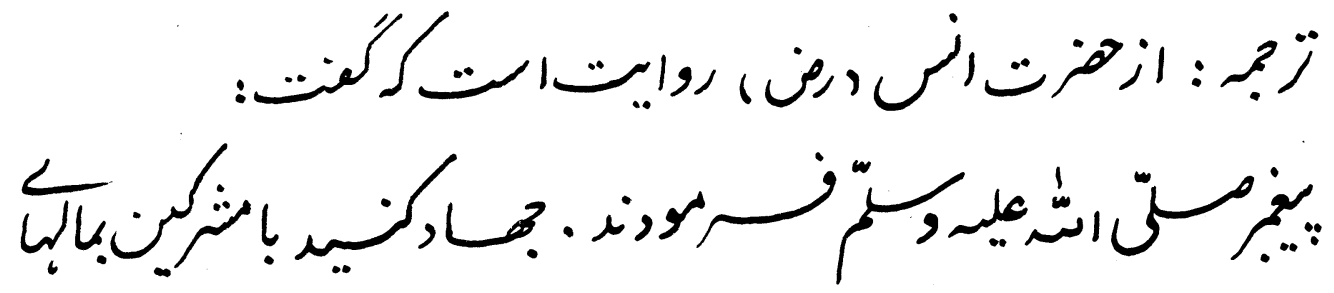

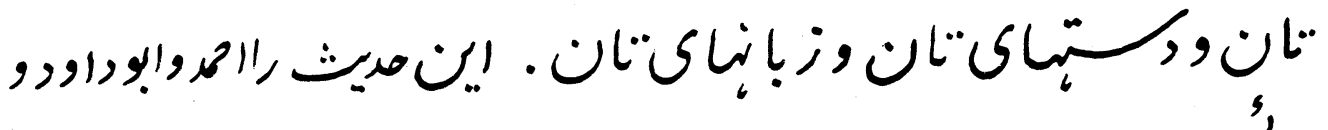

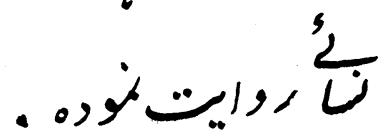

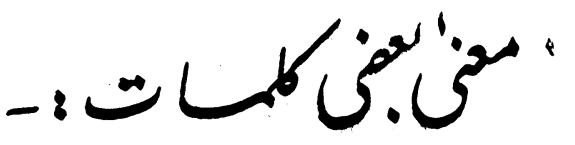

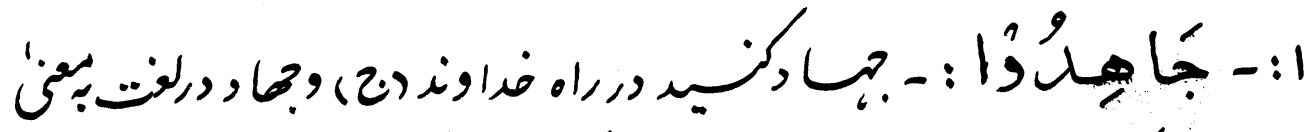

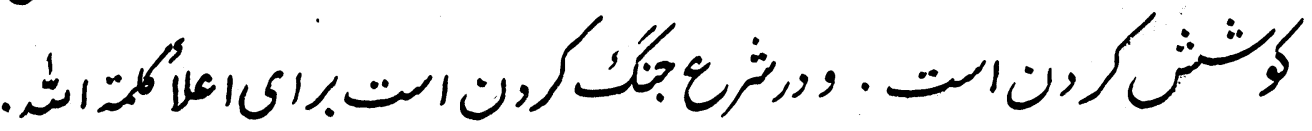

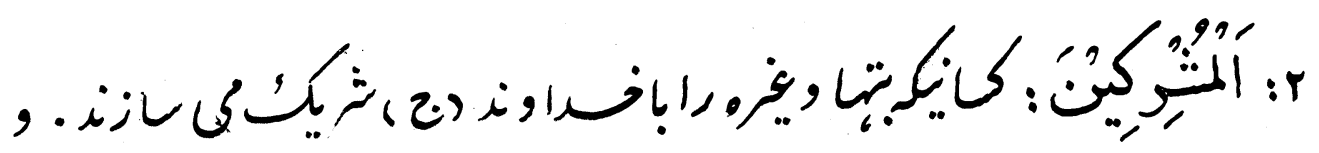

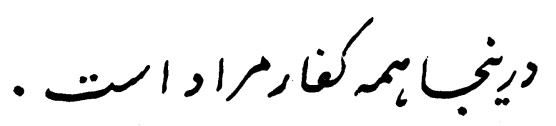

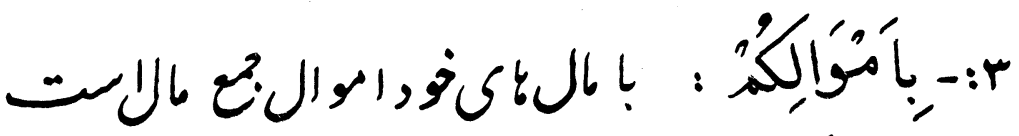

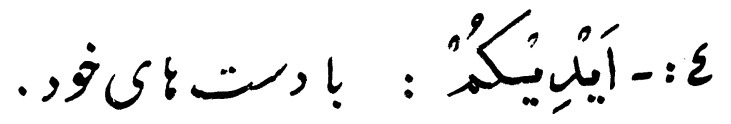
$+9$ 


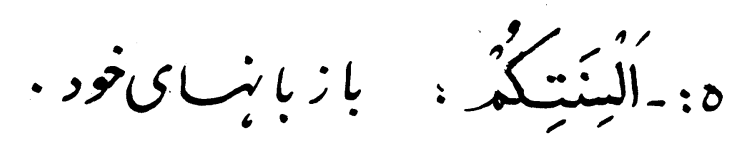

\section{توضنح :-}

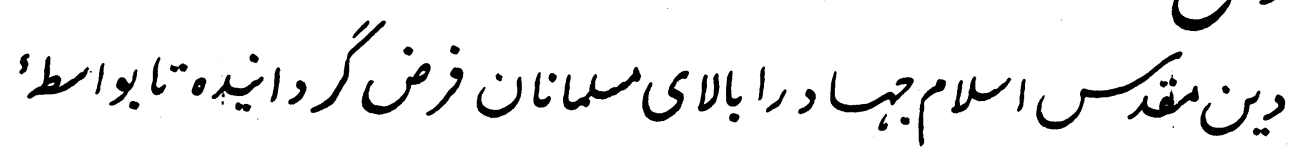

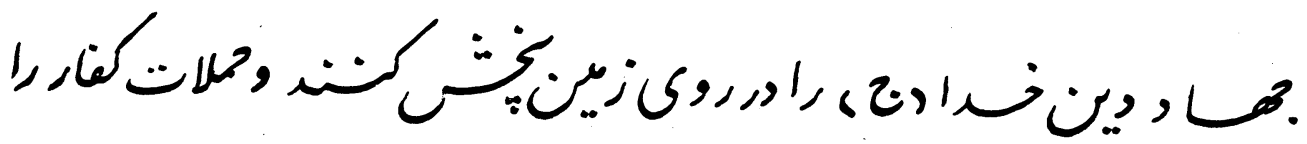

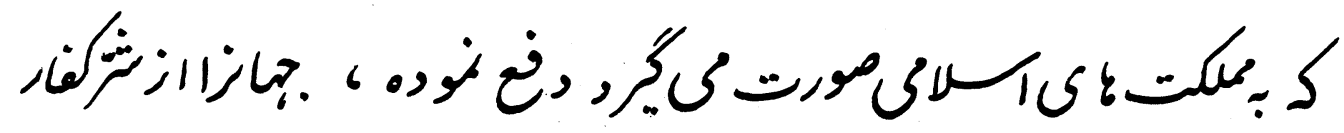

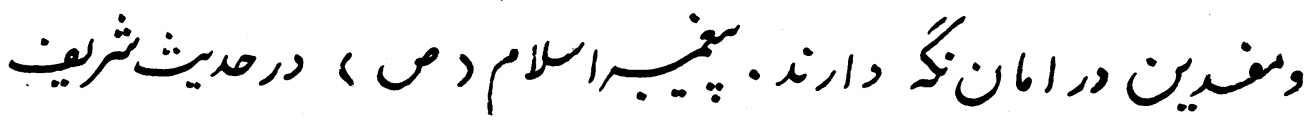

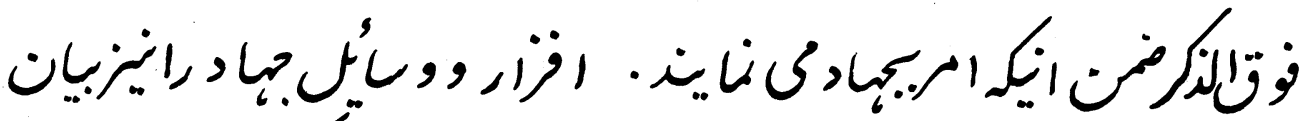

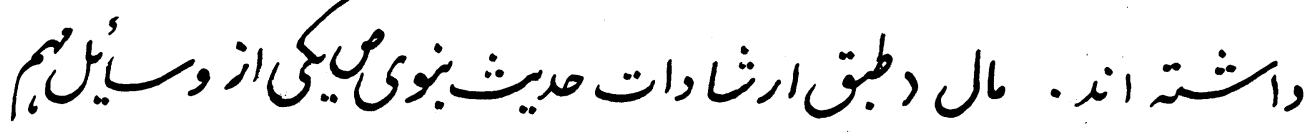

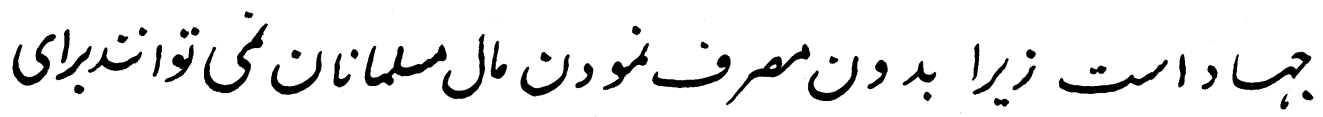

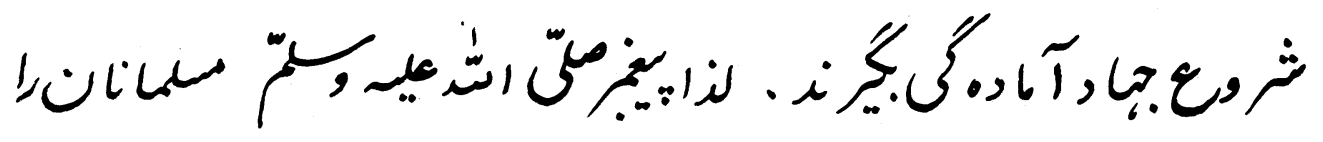

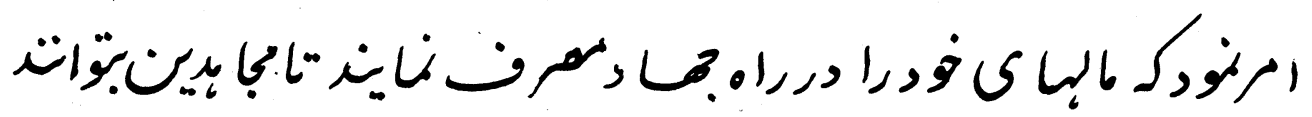

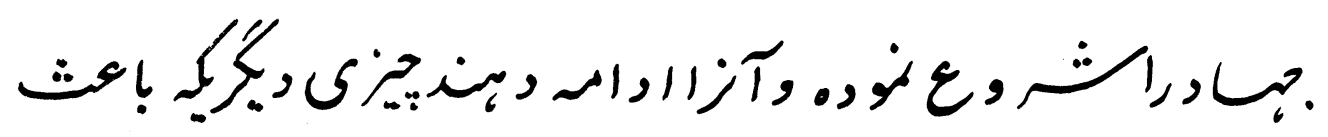

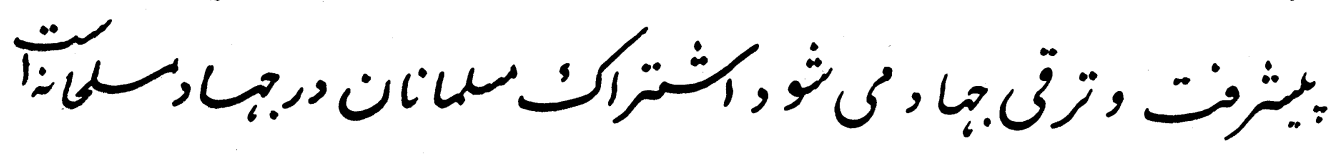




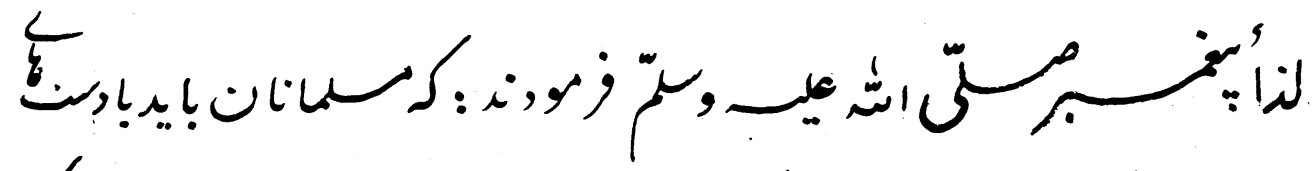

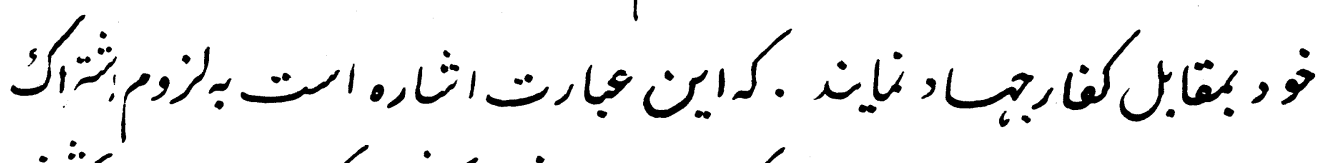

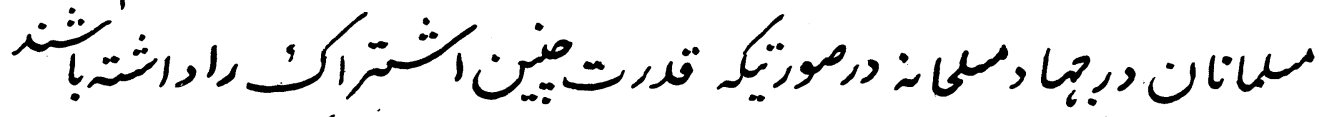

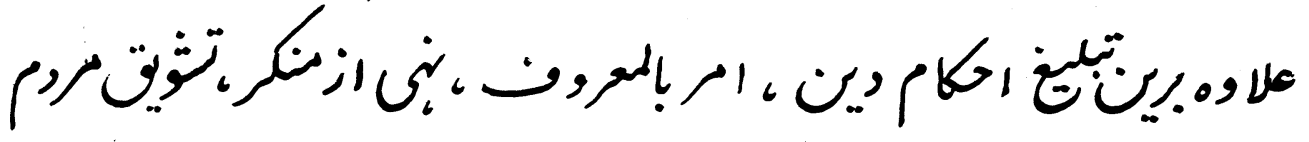

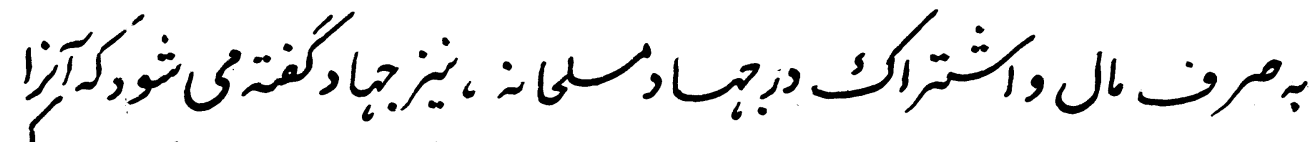

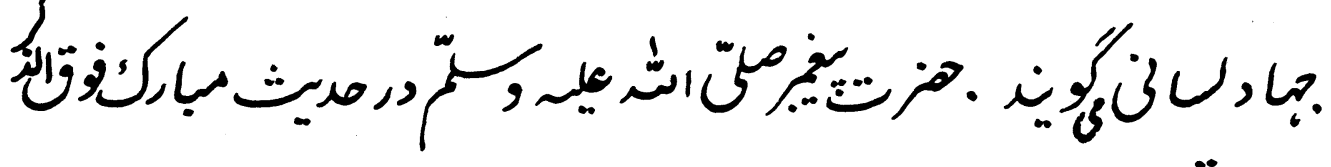

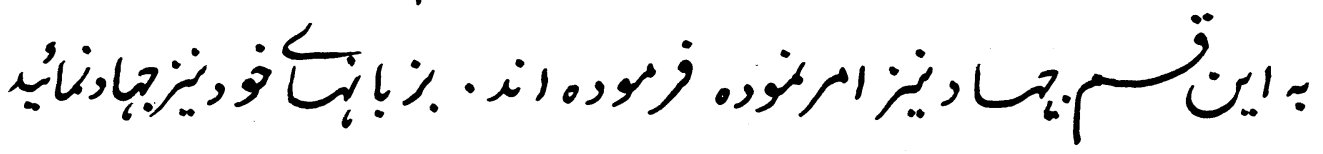

$$
\begin{aligned}
& \text { تمّن : }
\end{aligned}
$$

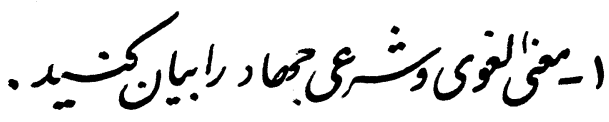

$$
\begin{aligned}
& \text { r- جماربال راتثيعنائي . }
\end{aligned}
$$

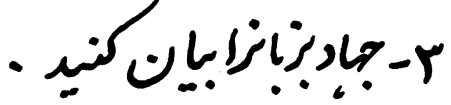




$$
\begin{aligned}
& \text { توقنمن }
\end{aligned}
$$

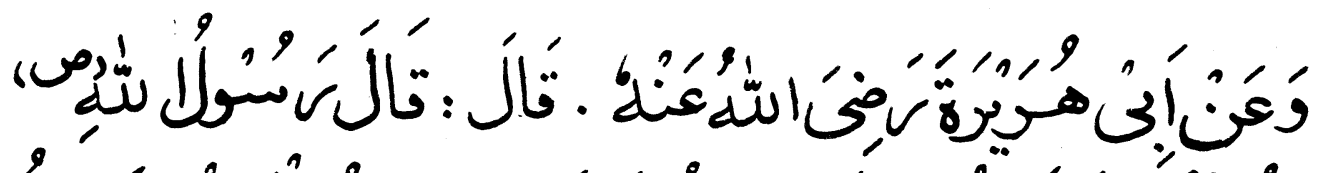

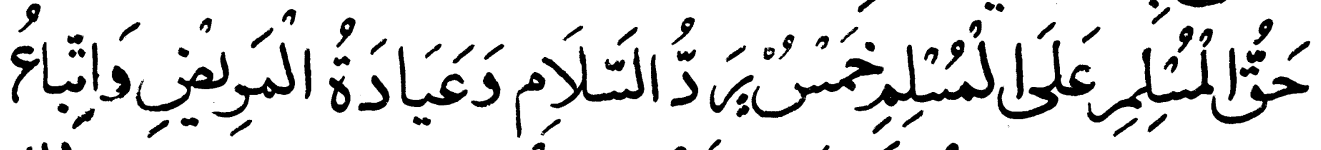

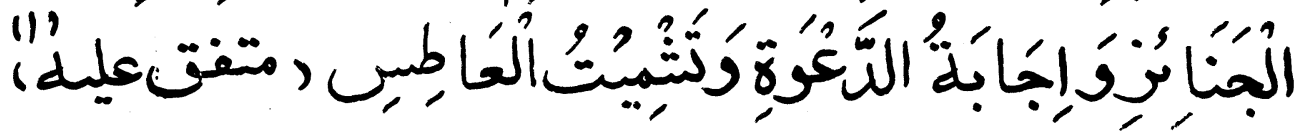

$$
\begin{aligned}
& \text { ק"جم: - }
\end{aligned}
$$

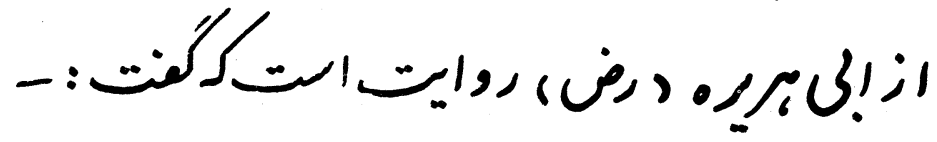

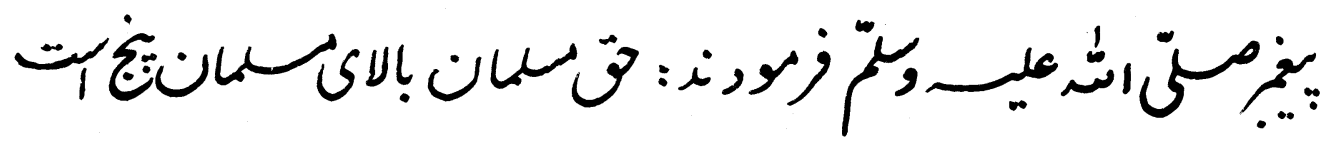

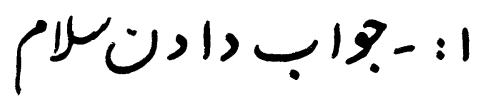

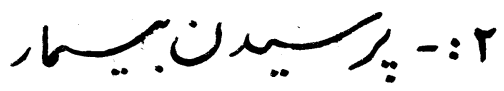

$$
\begin{aligned}
& \text { r. } \\
& \text { (r) }
\end{aligned}
$$

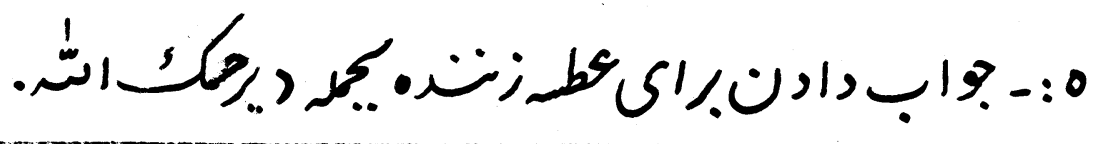

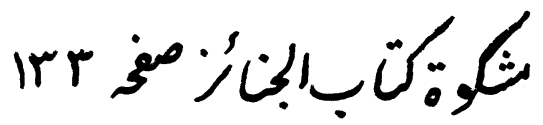




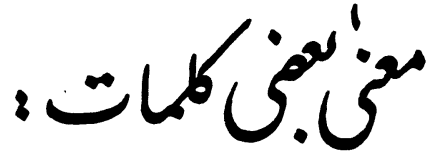

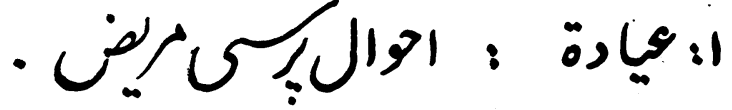

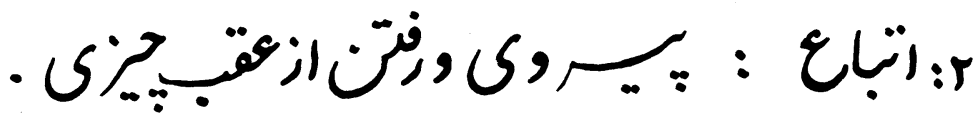

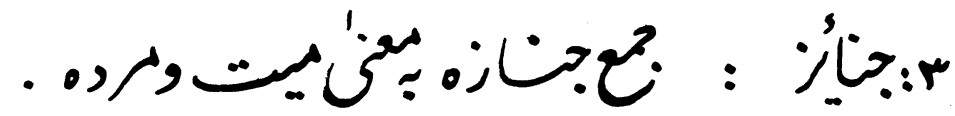

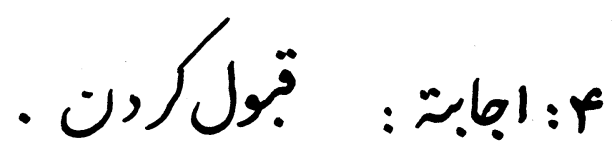

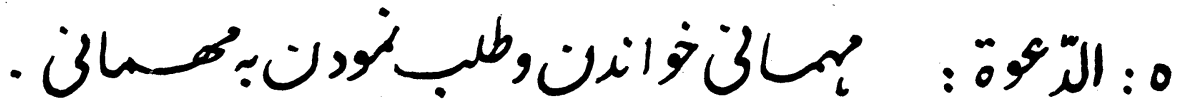

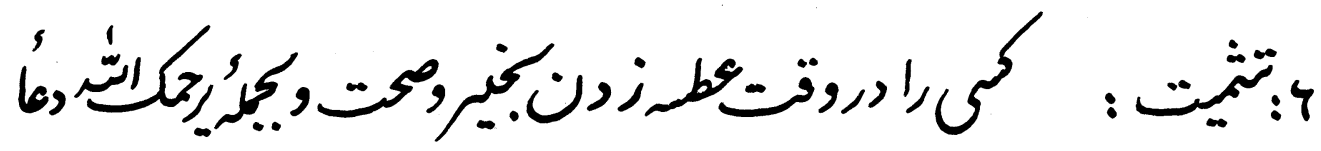

$$
\text { .... }
$$

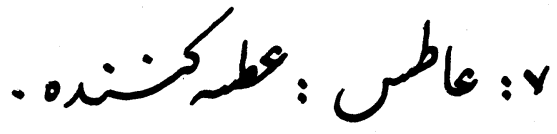

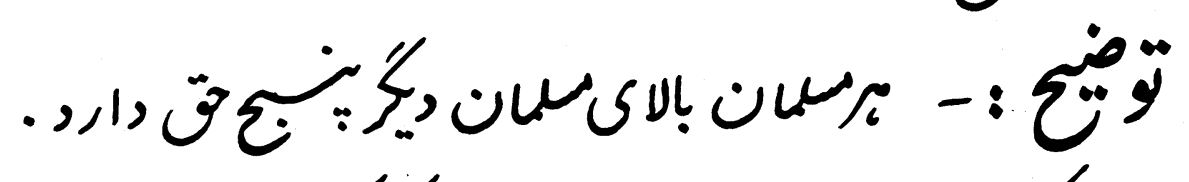

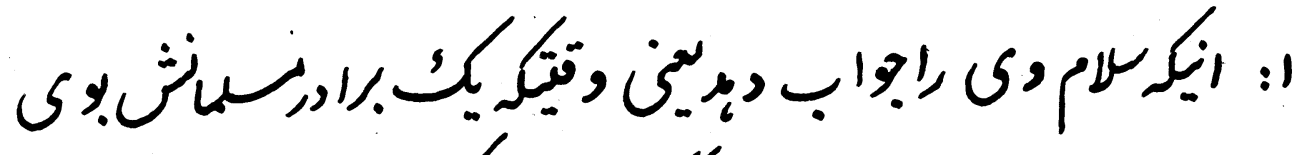

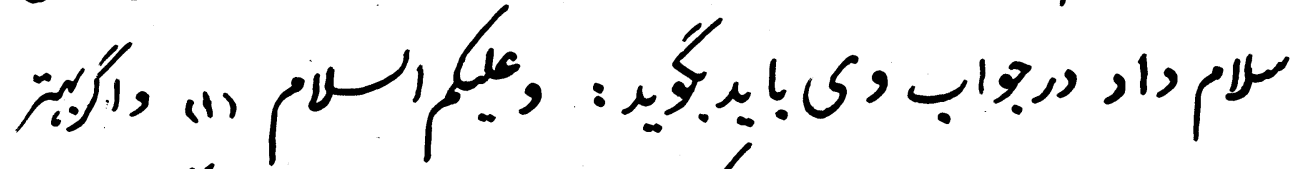

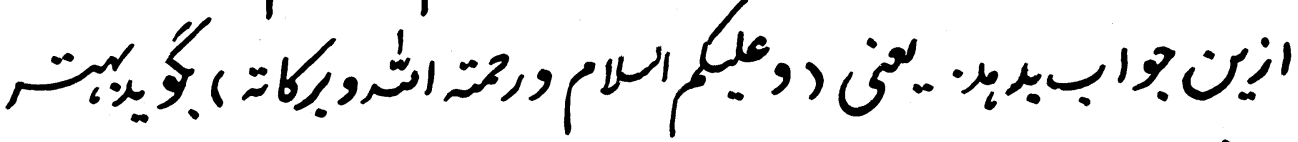

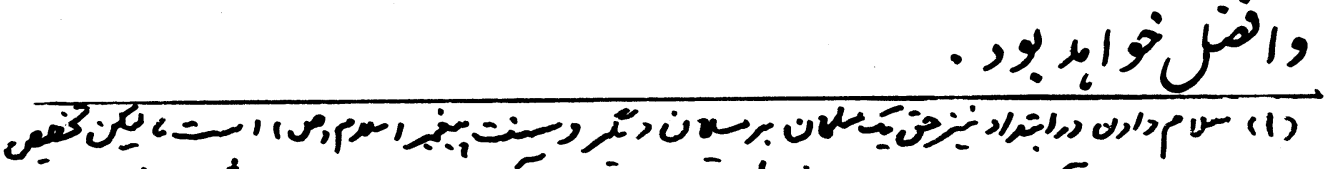

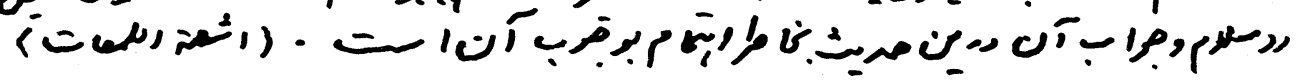

or 


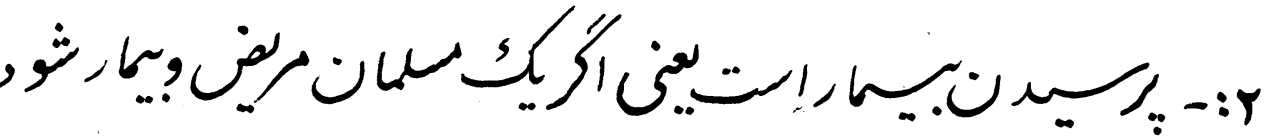

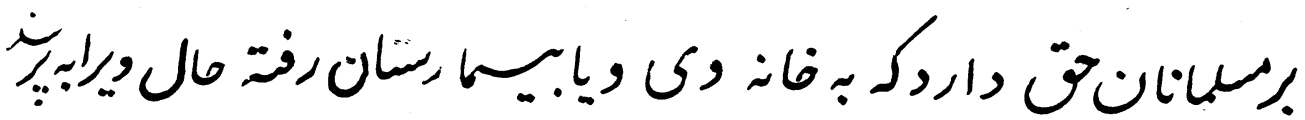

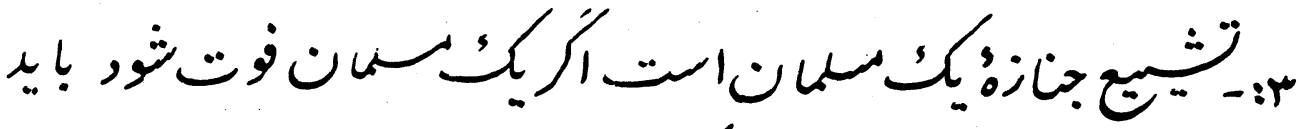

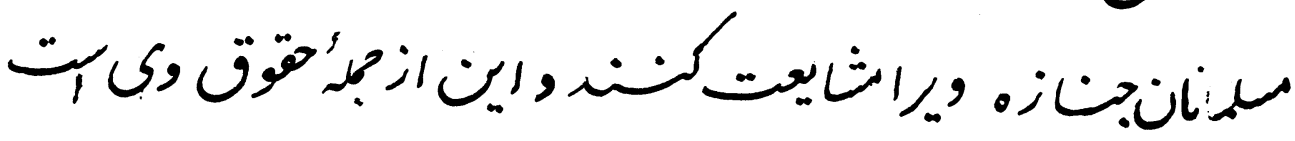

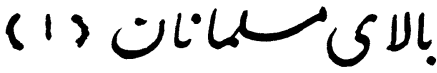

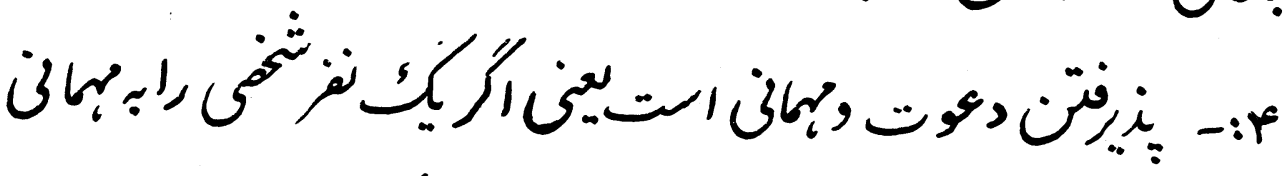

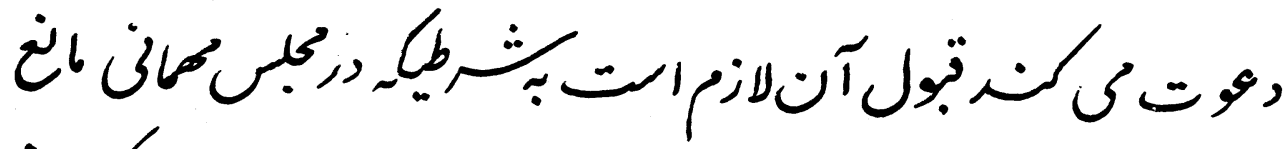

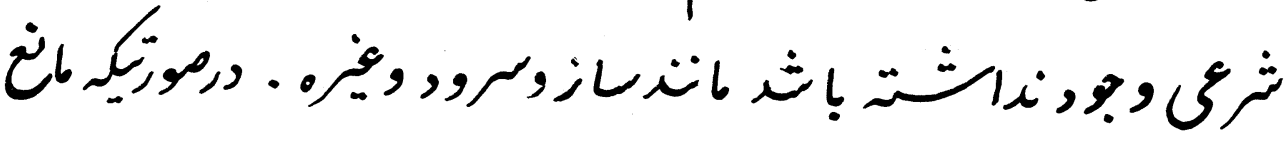
•

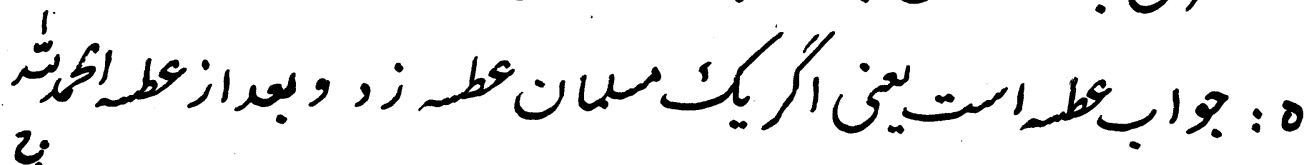

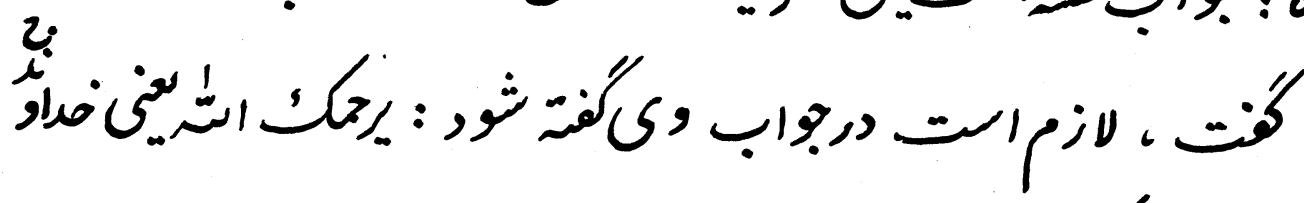

(1) تخهي

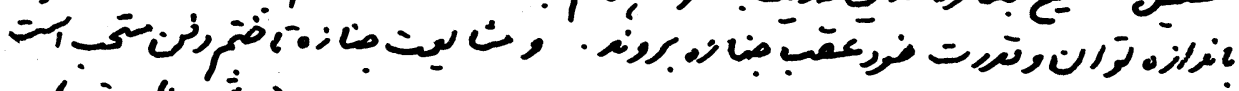
(ivisis) 


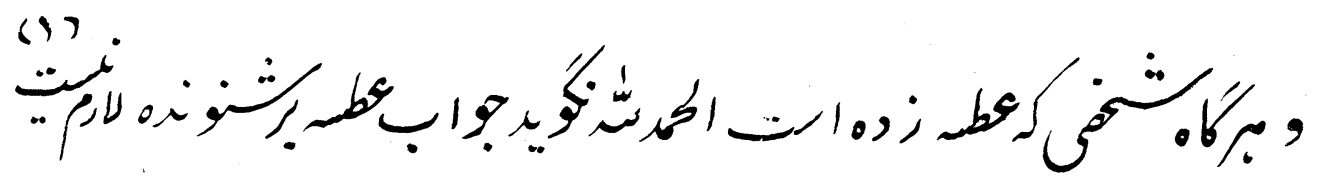

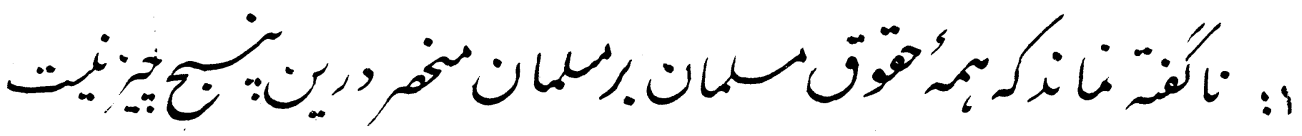

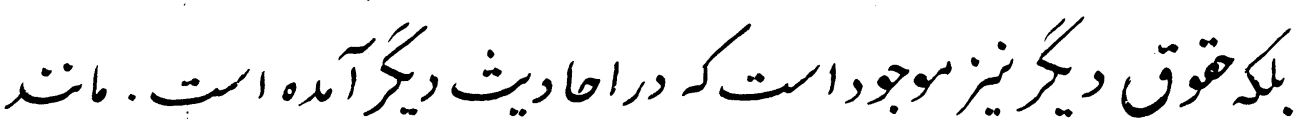

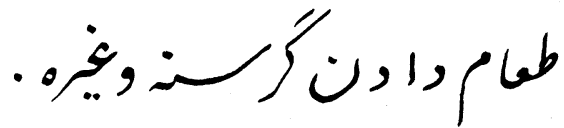

ק̈

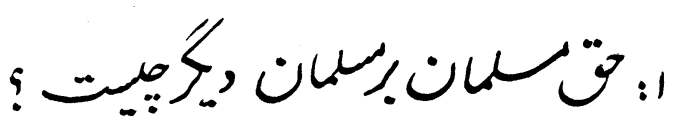

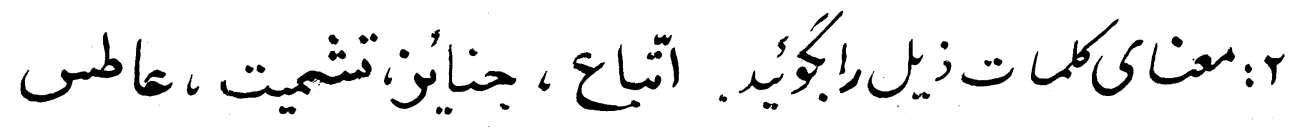

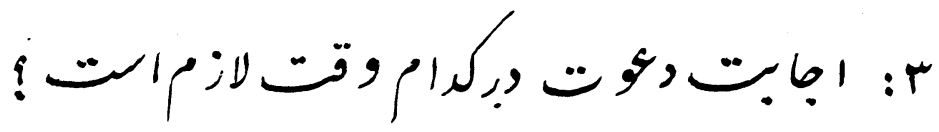

ه 


\section{ن}

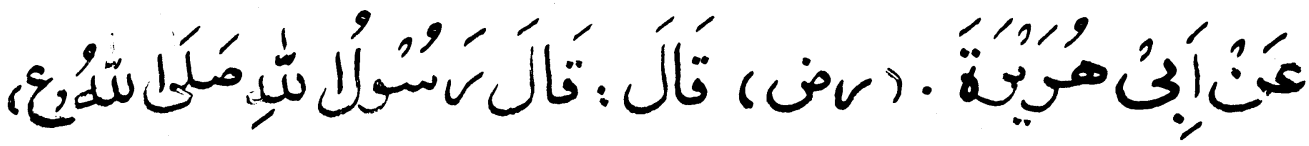

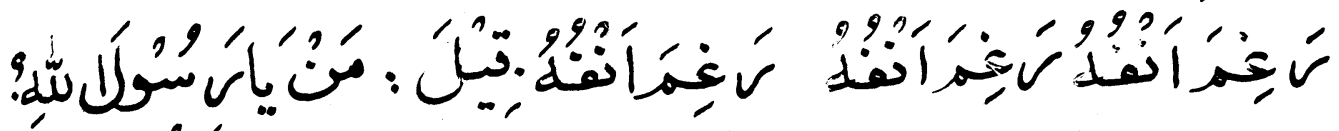

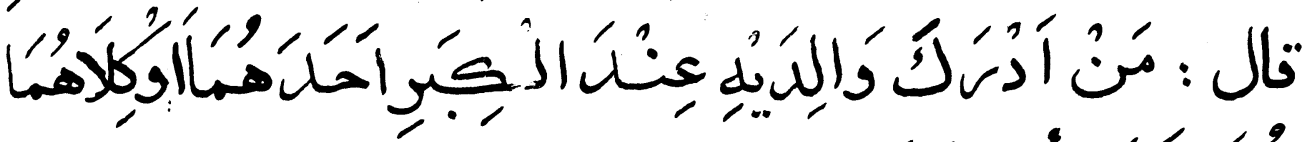

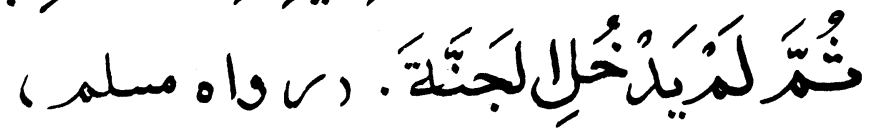

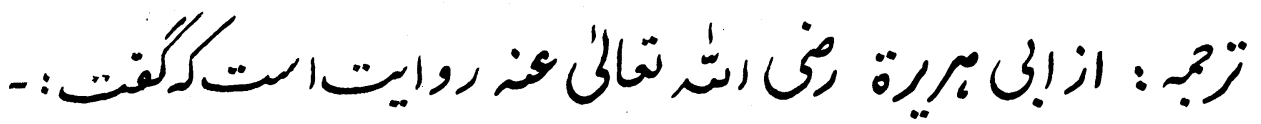

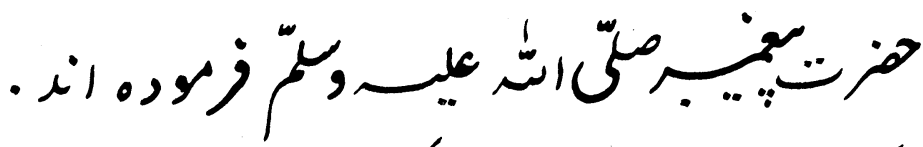

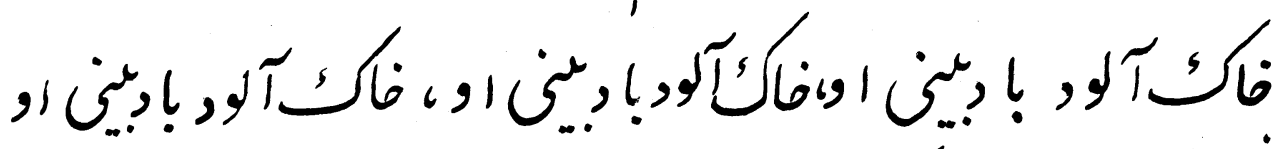

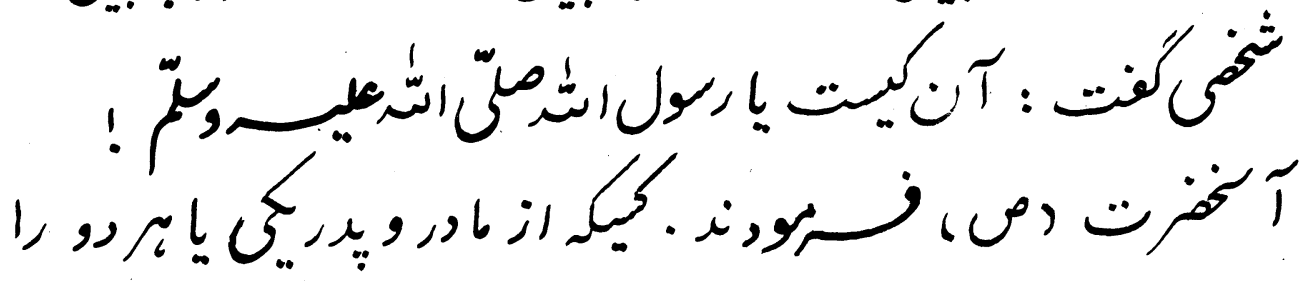

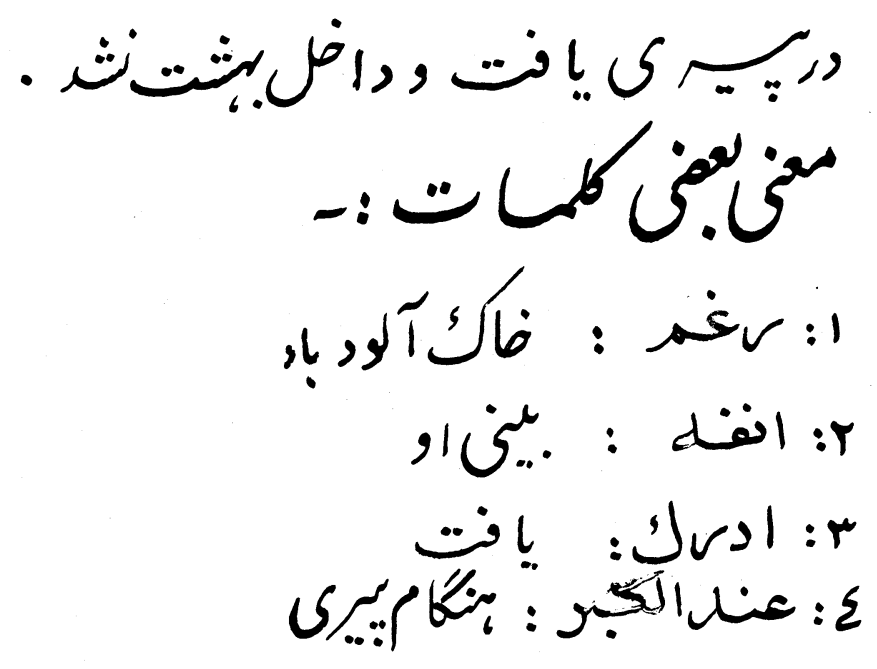
कI 


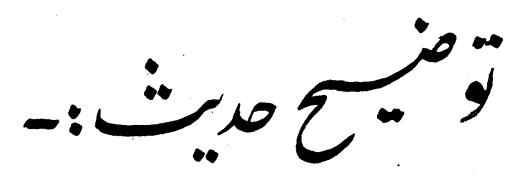

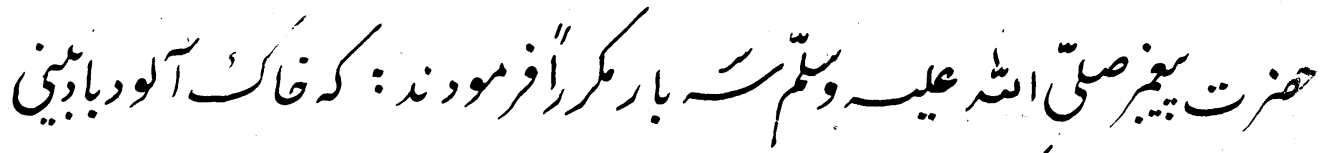

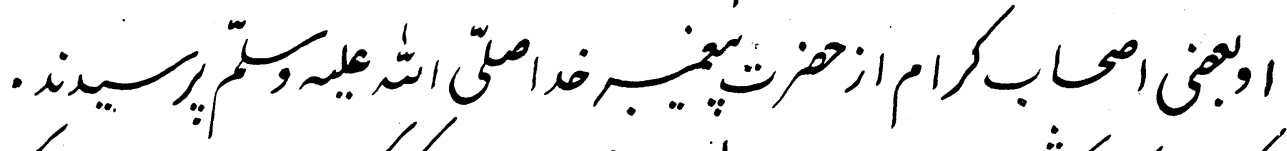

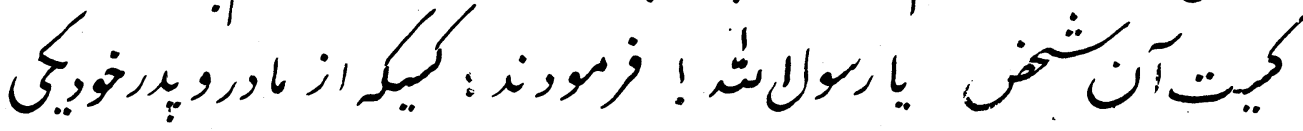

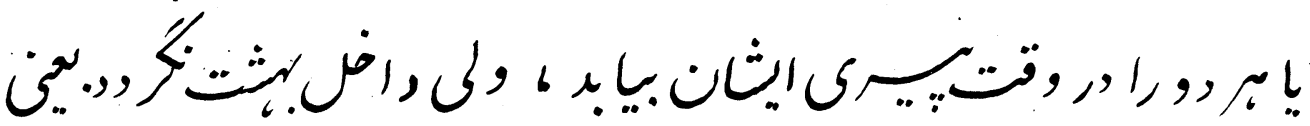

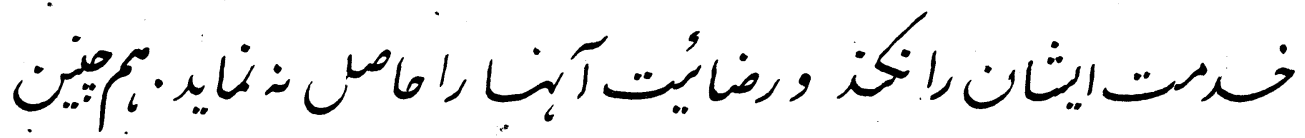

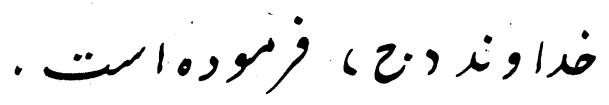

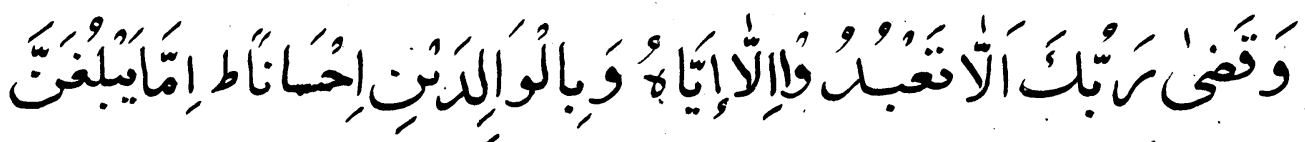

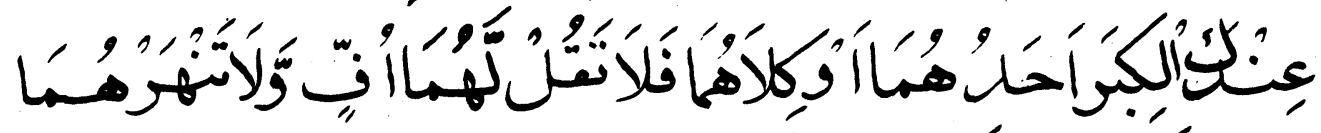

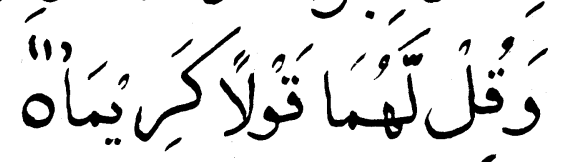

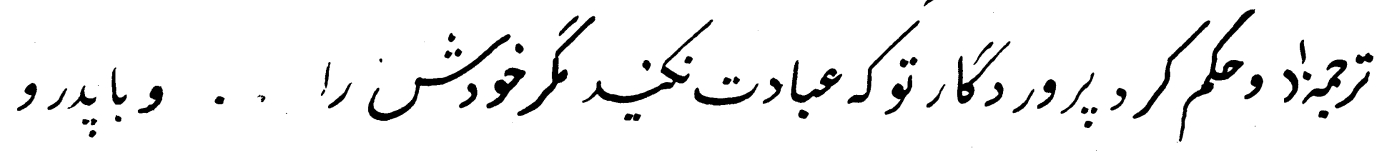

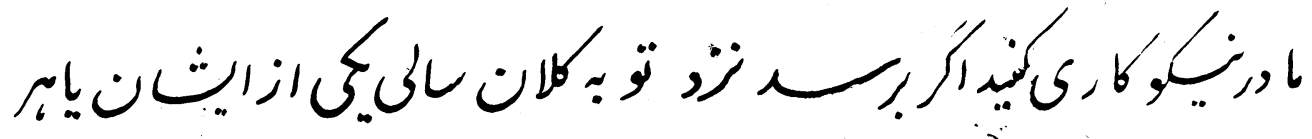

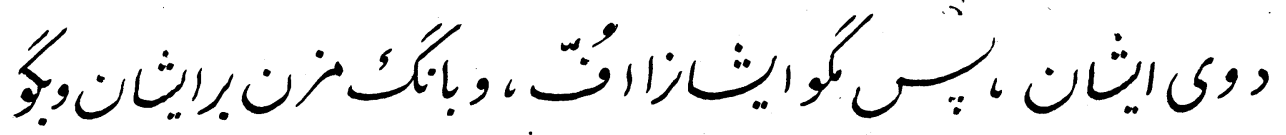

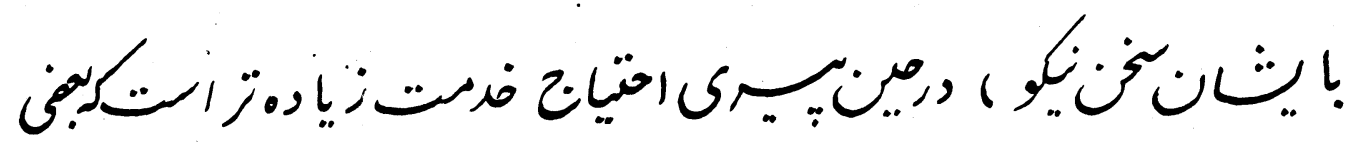

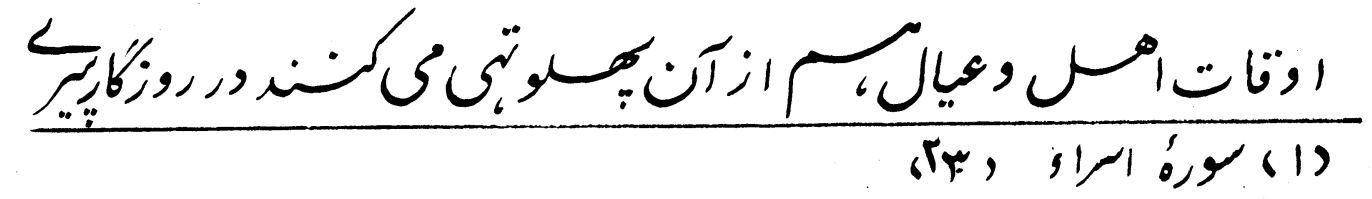




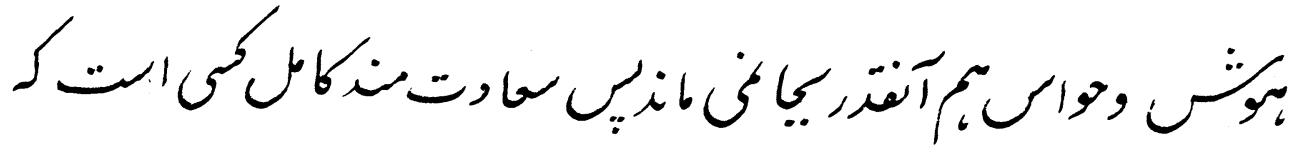

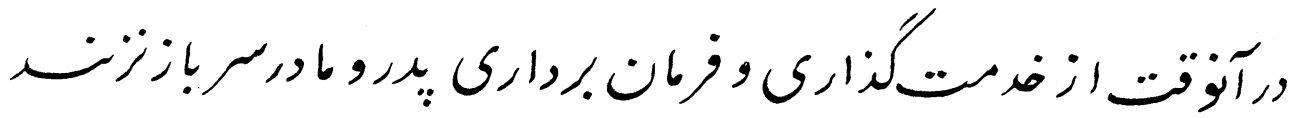

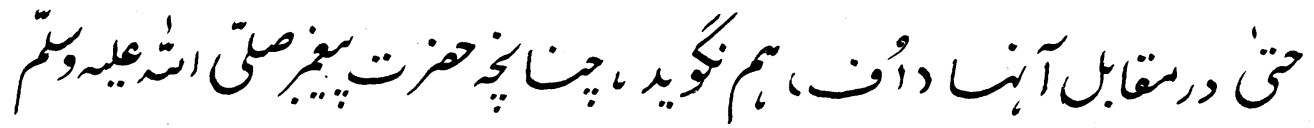

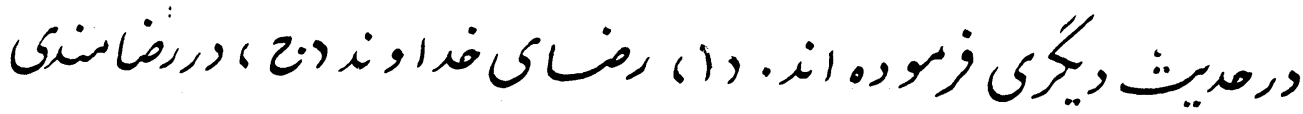

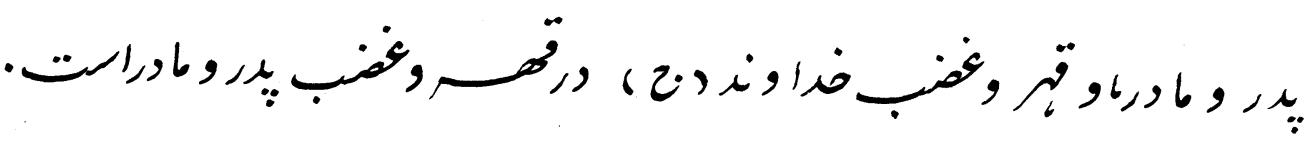

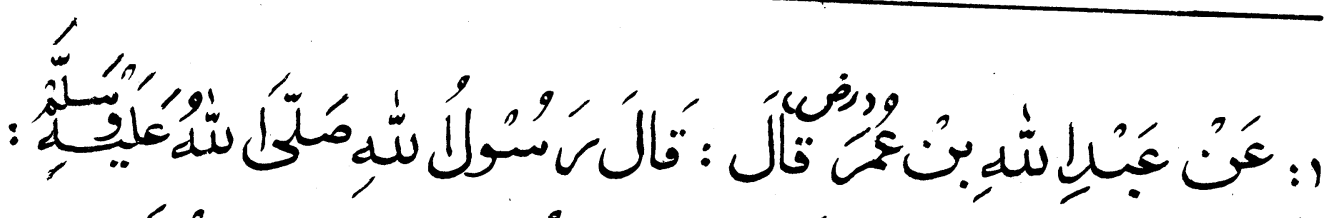

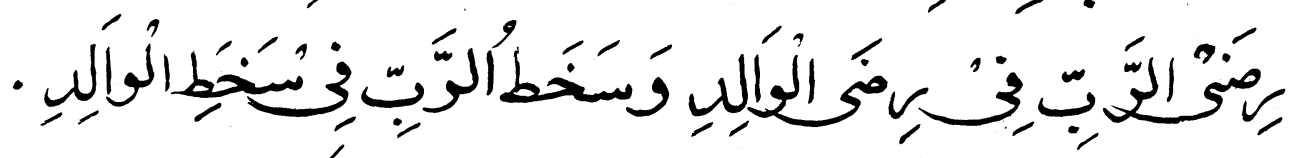
)

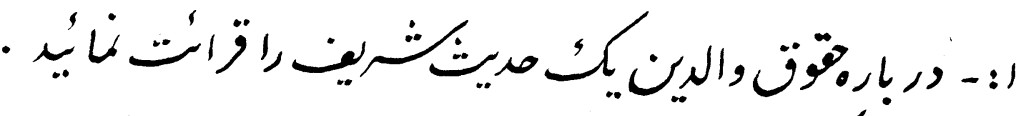

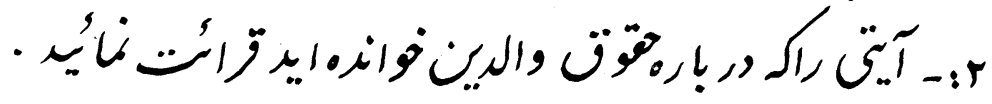

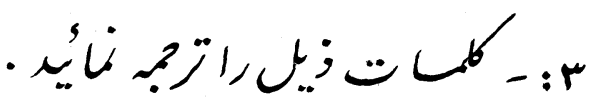

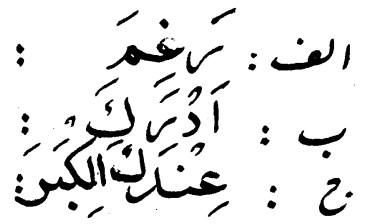




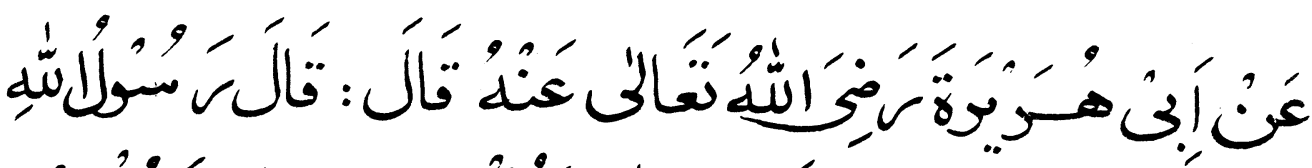

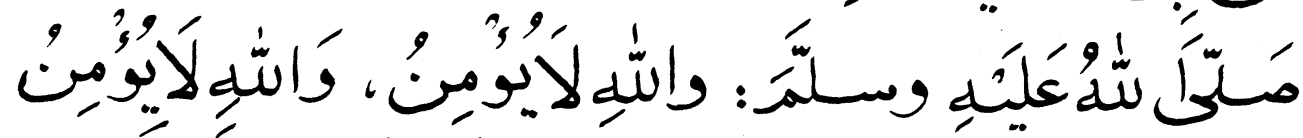

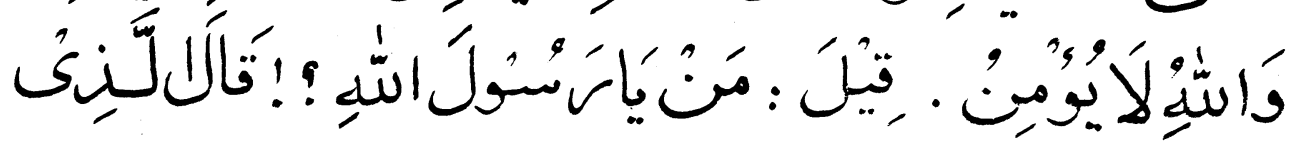

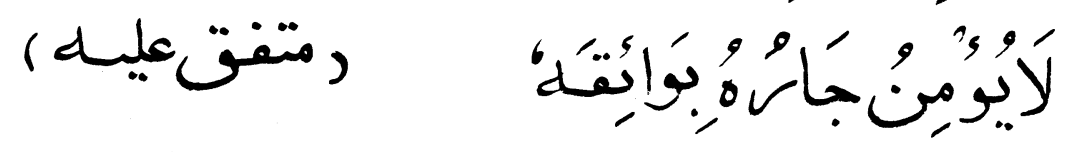

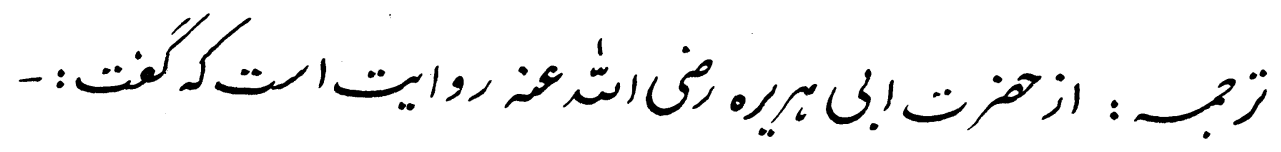

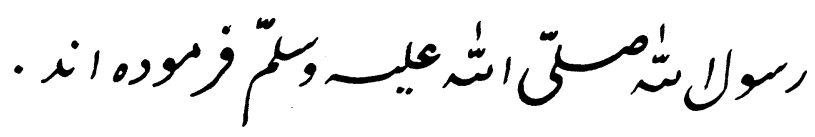

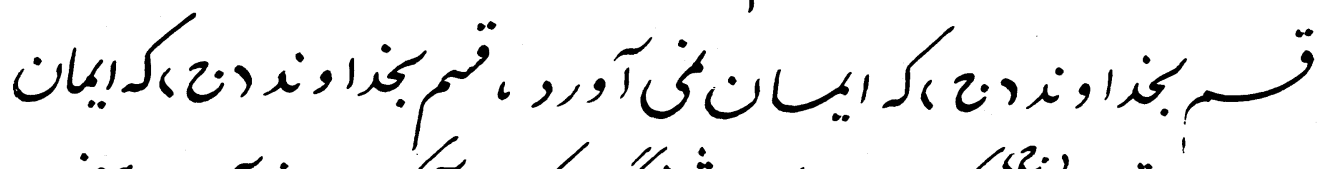

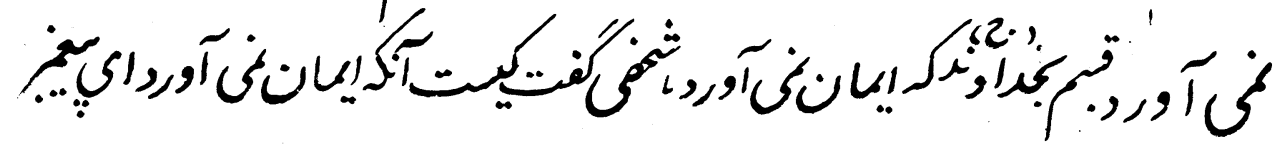

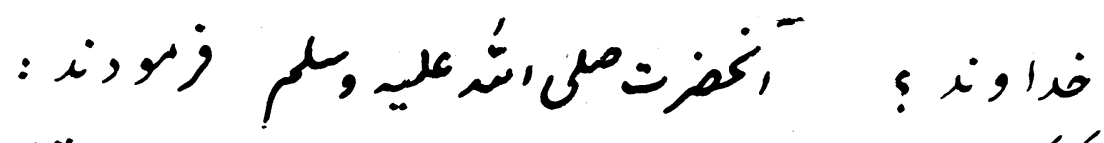

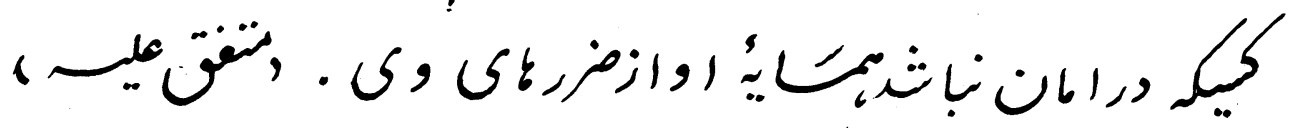

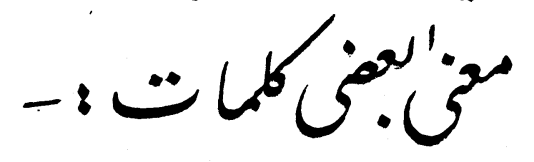

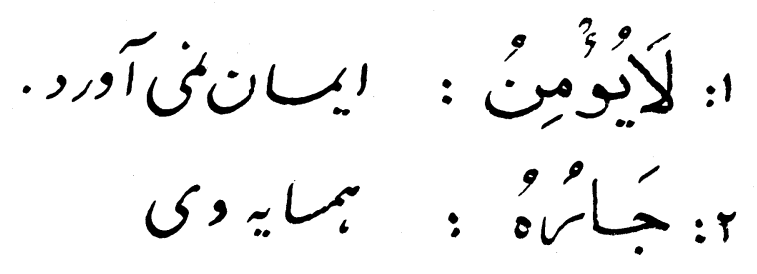

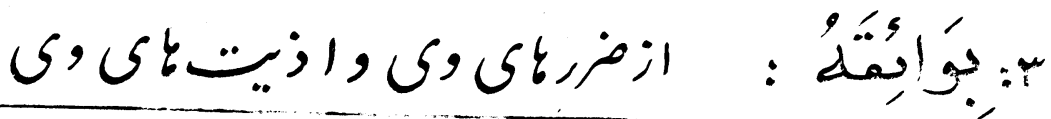
$\Delta q$ 


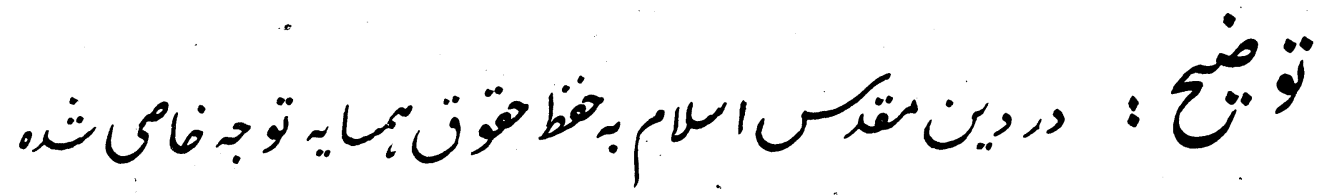

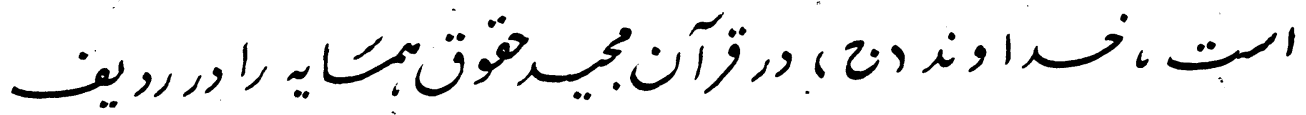

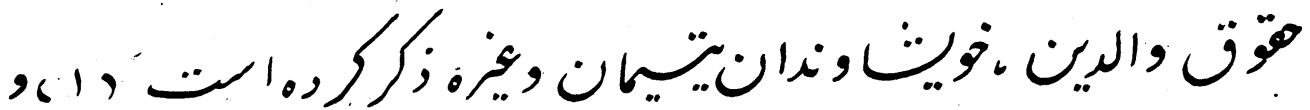

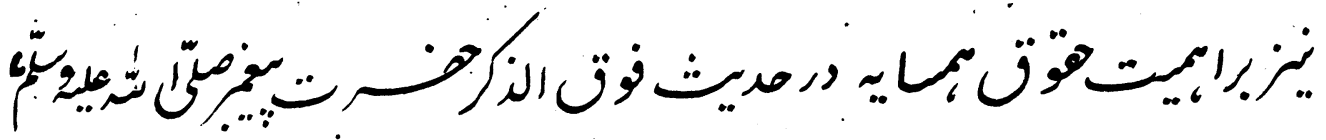

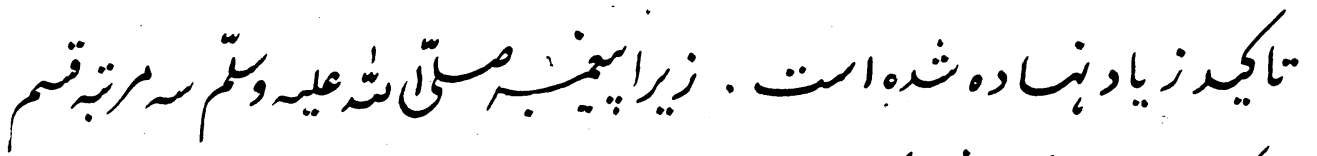

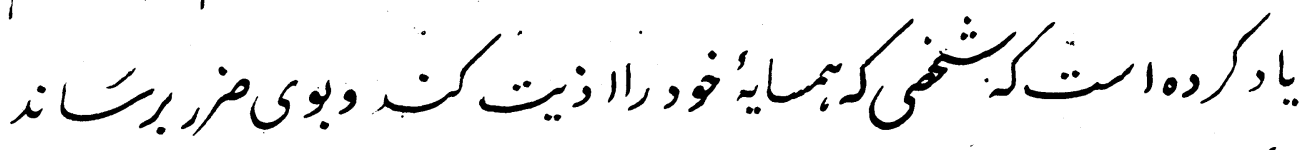

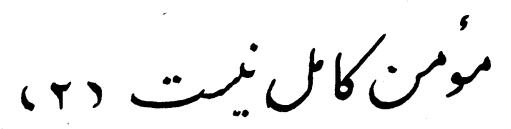

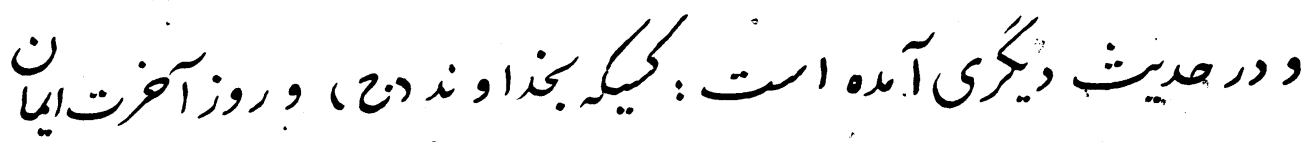

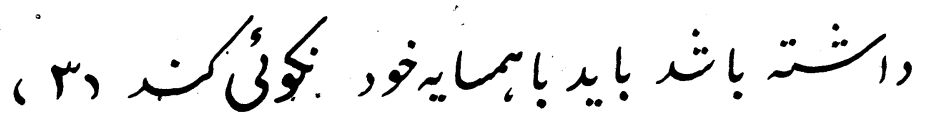
יاים

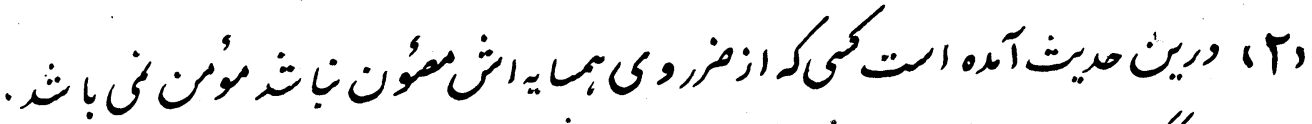

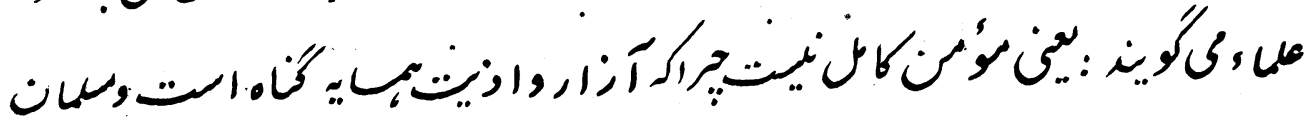

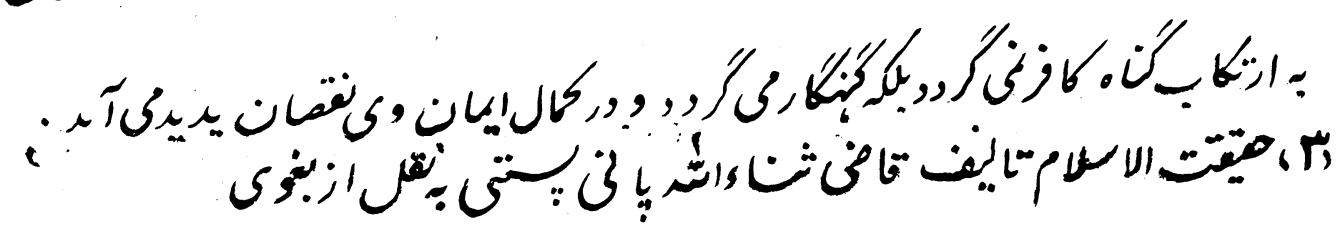




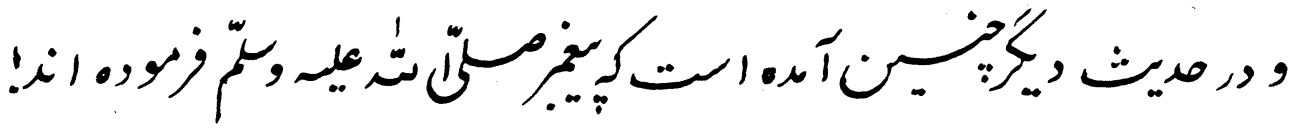
ممايهكى.

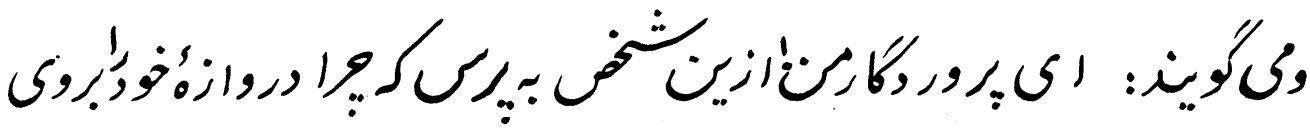

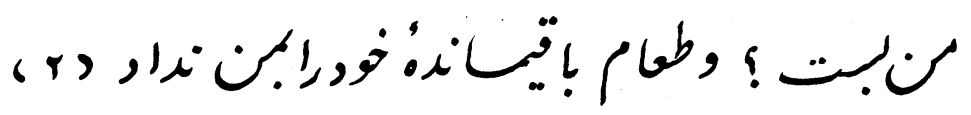

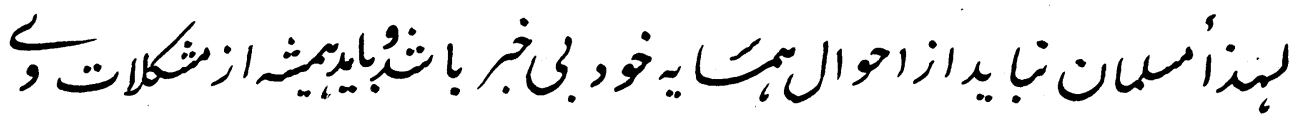

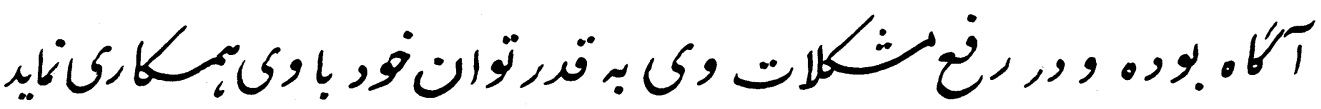

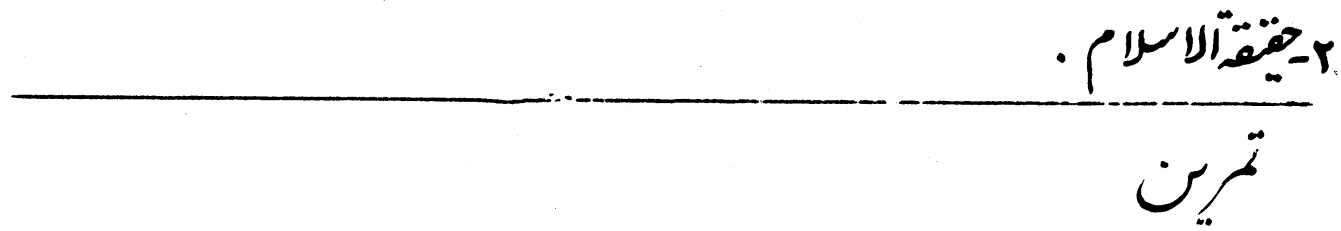

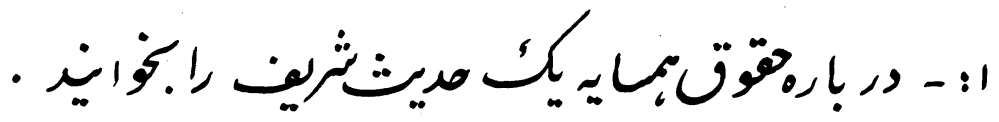

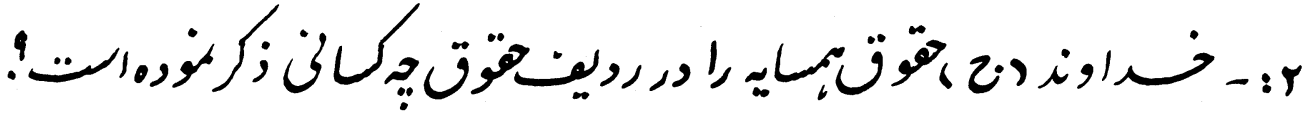

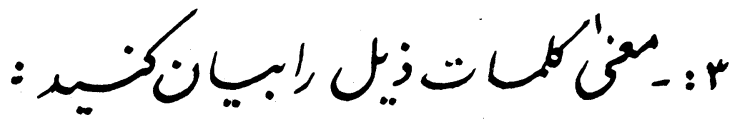

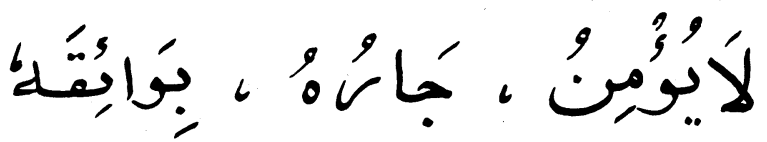




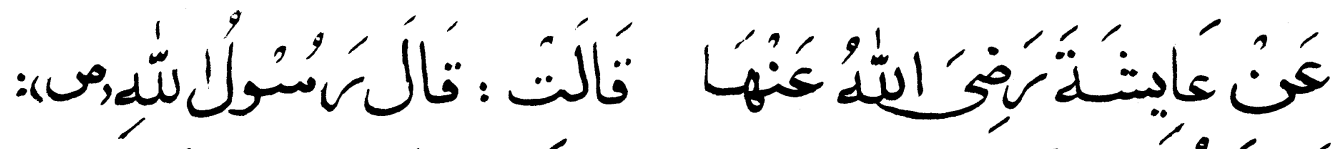

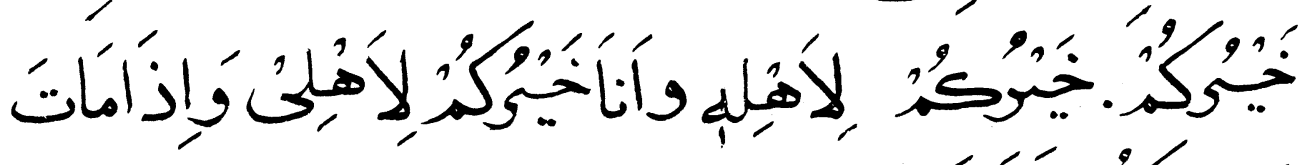

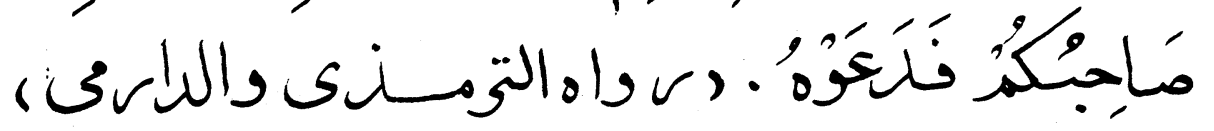

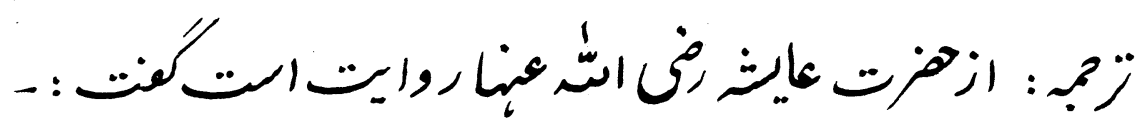

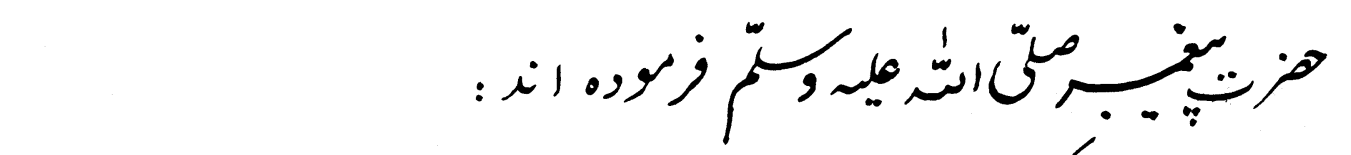

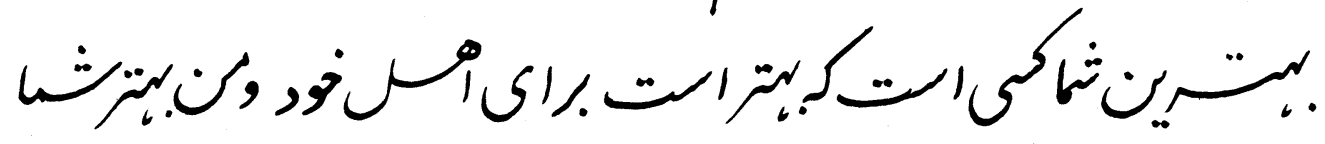

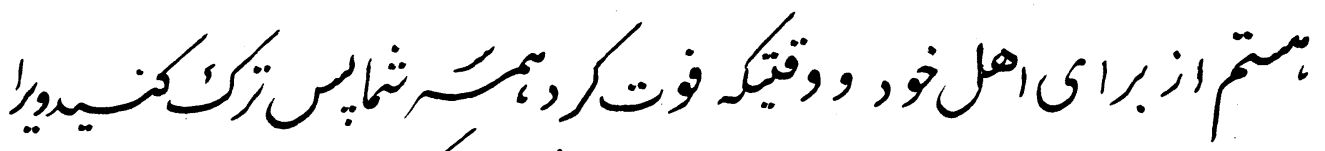

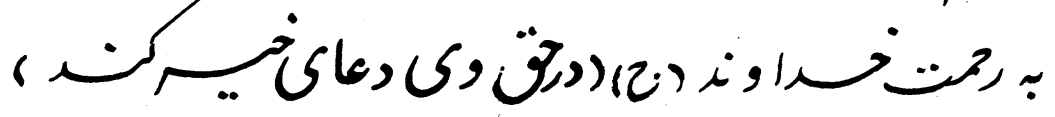

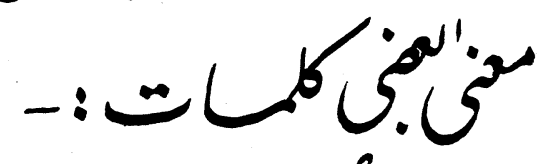

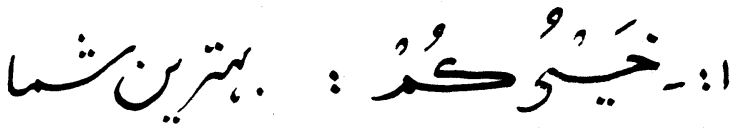

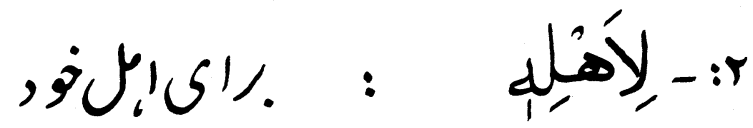
r:s

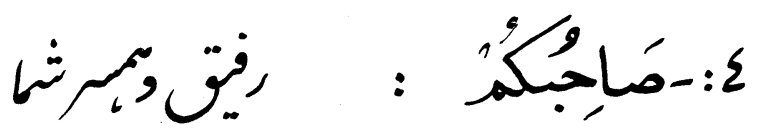




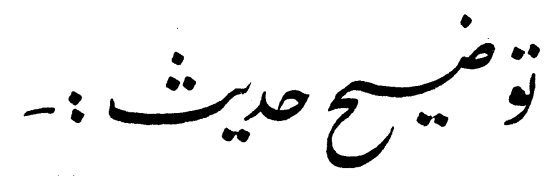

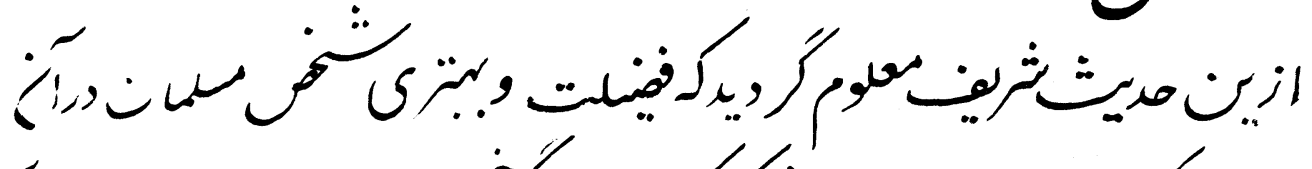

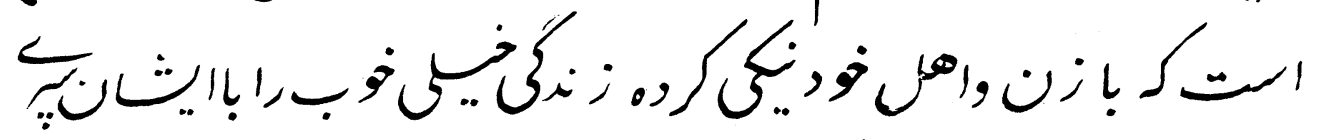

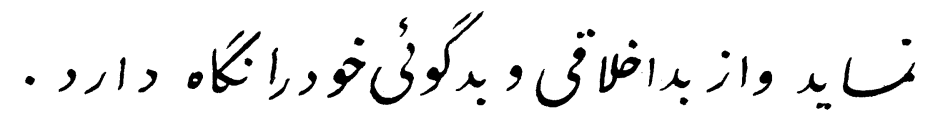

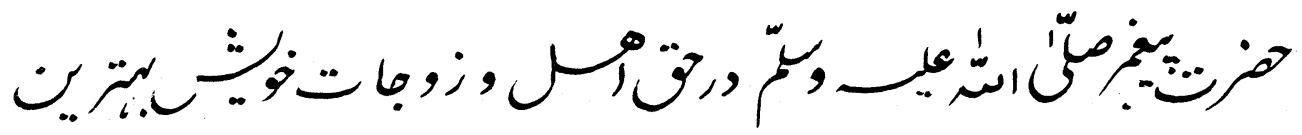

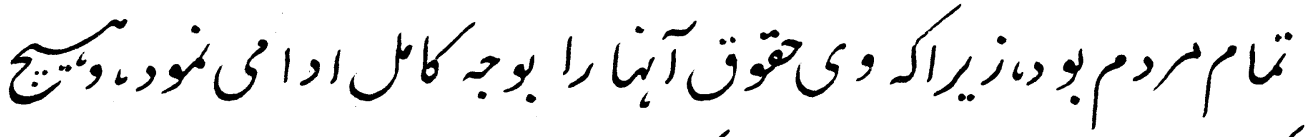

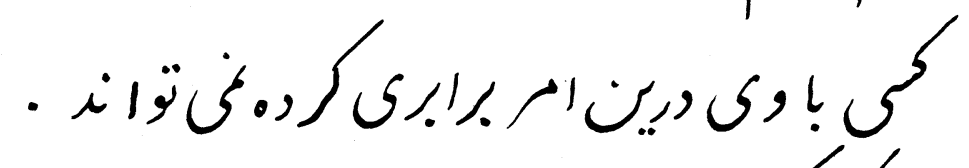

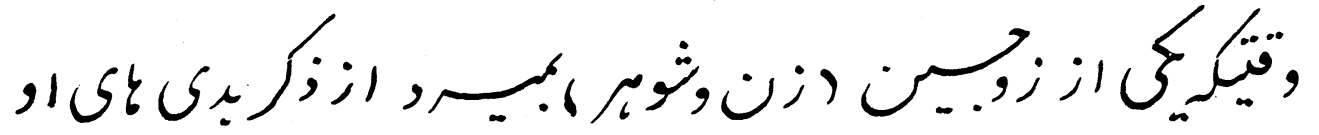

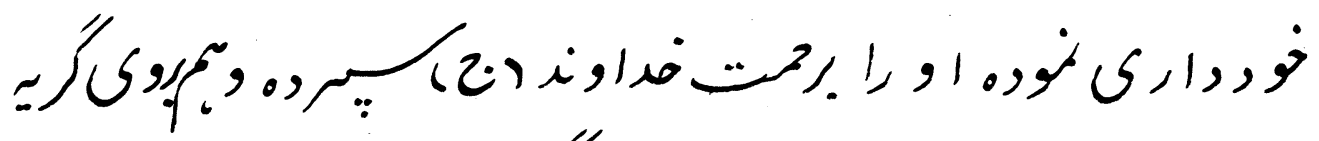

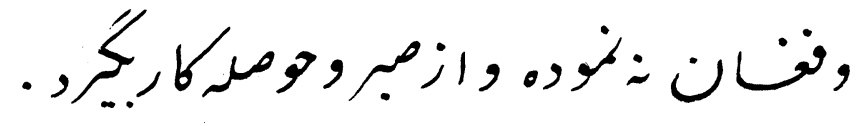

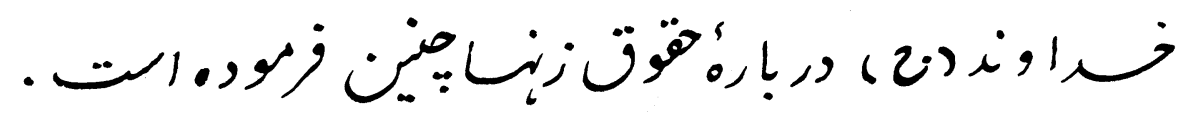

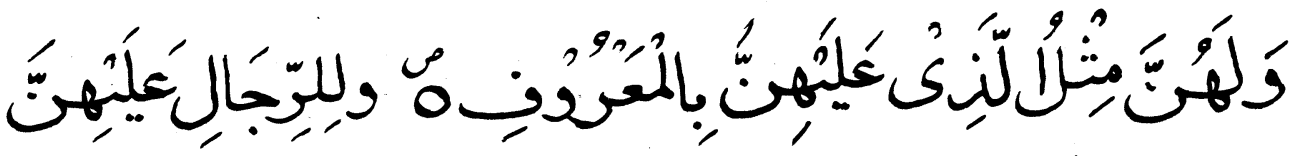

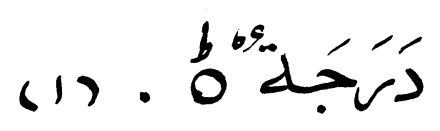

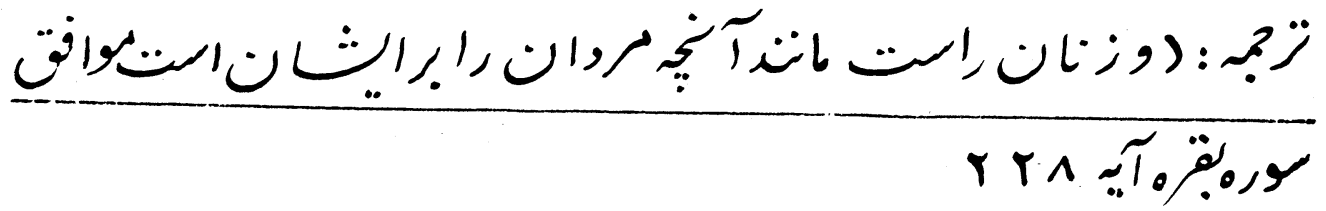




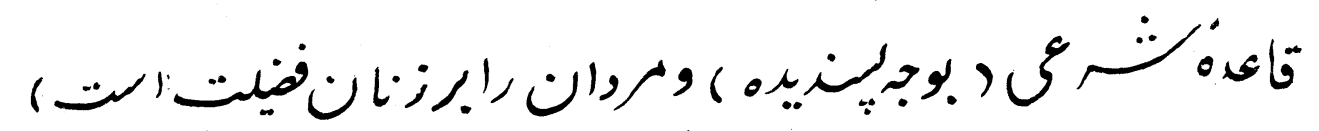

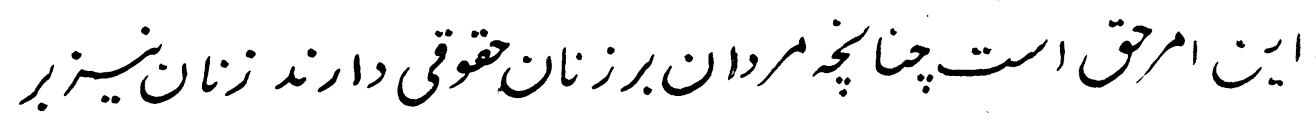

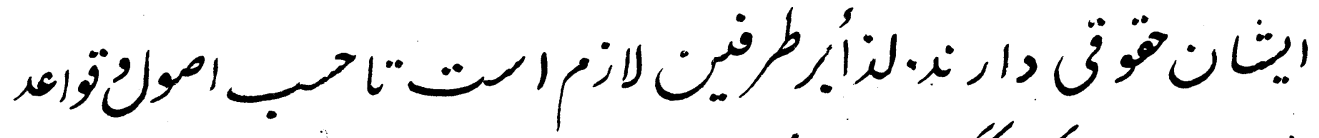

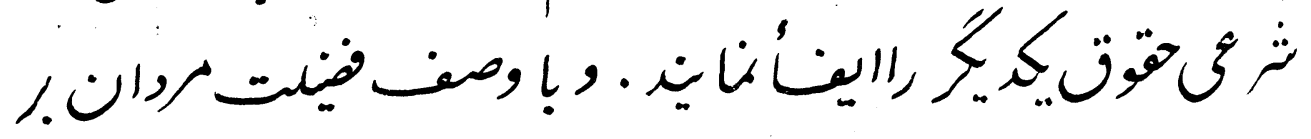

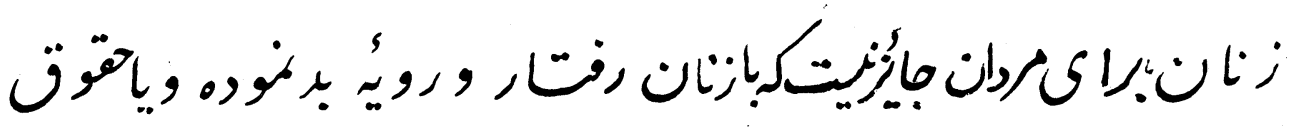

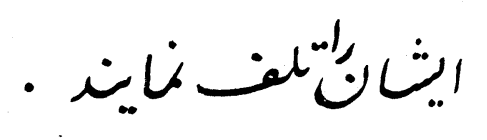
(2) راتتتباثي

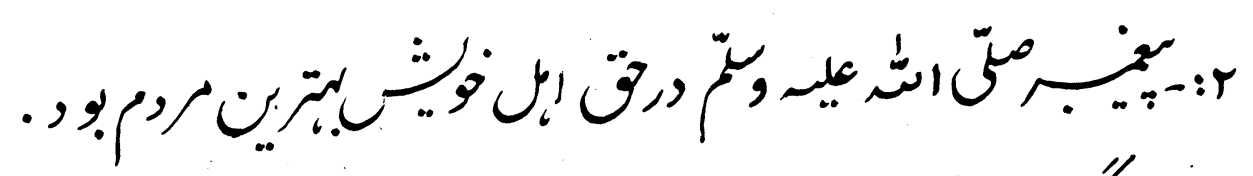

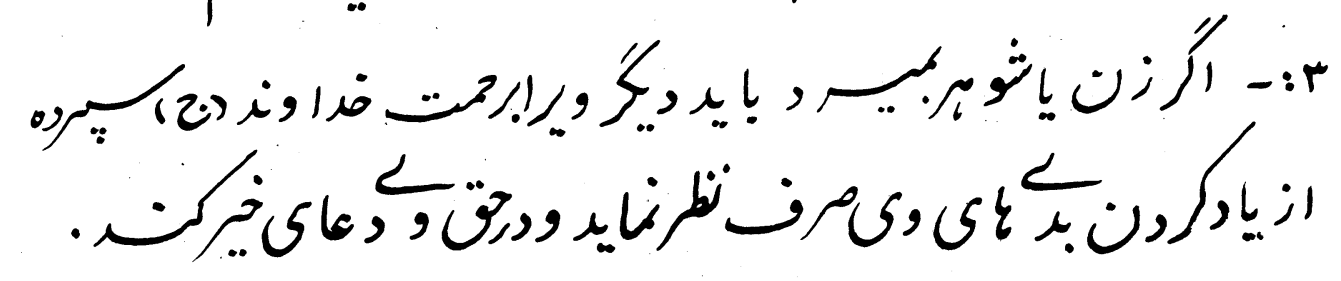




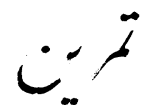

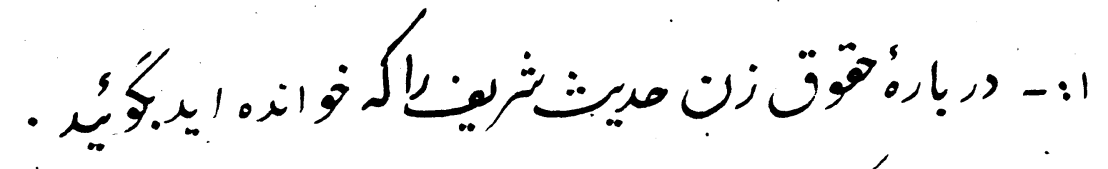

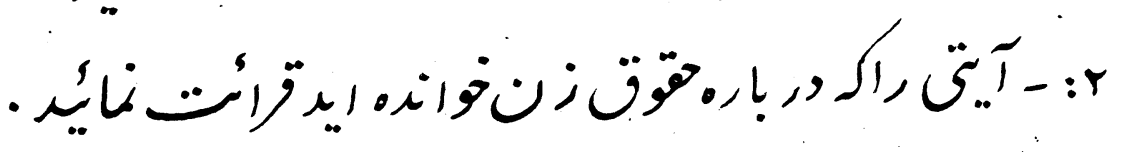

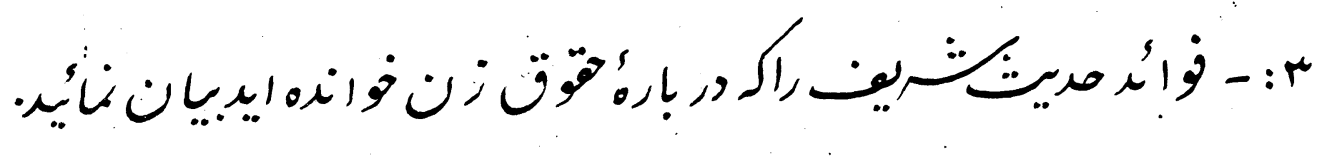

90 


\section{تغتتبراولا,}

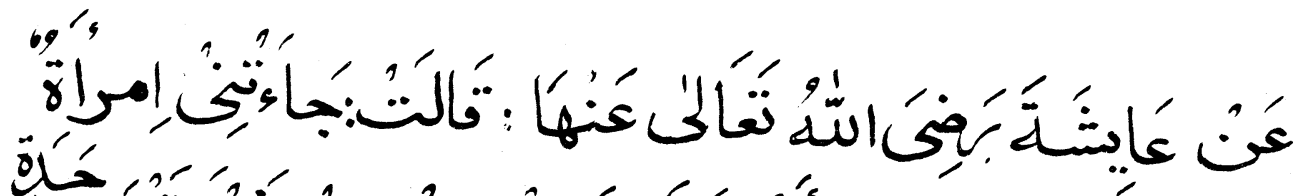

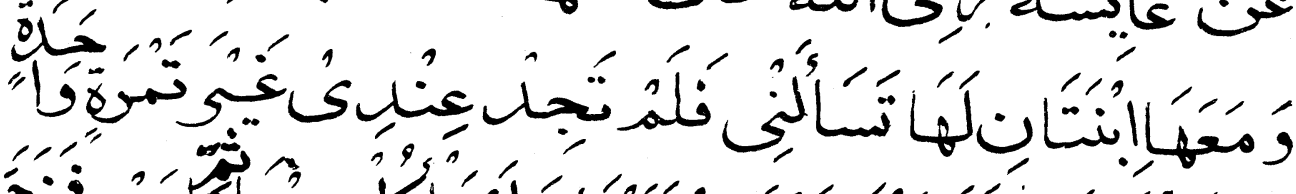

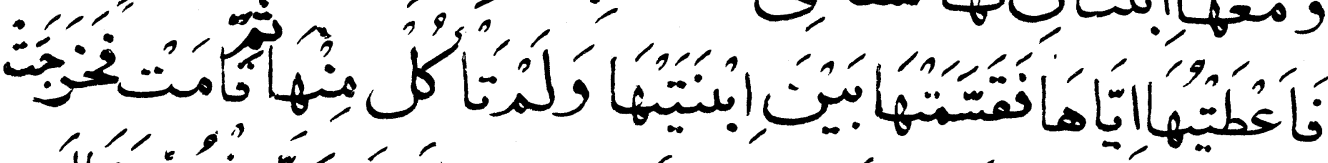

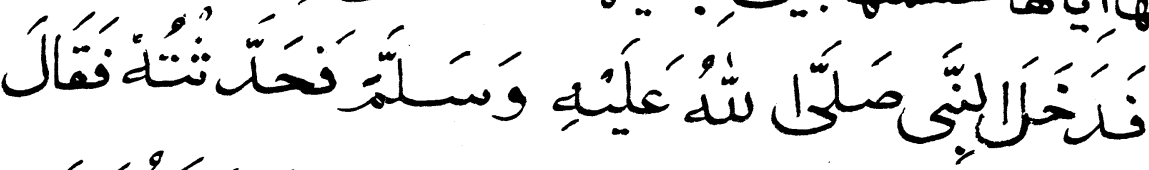

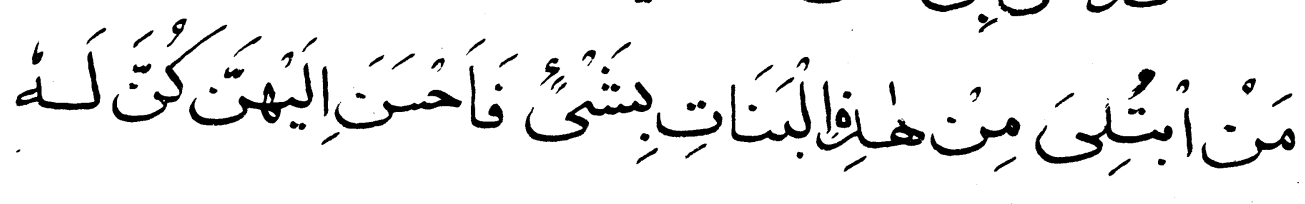

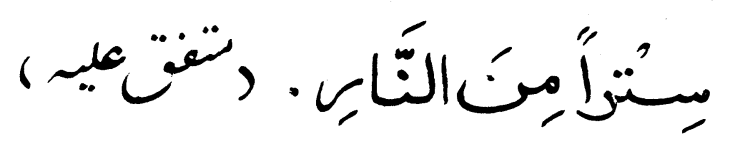

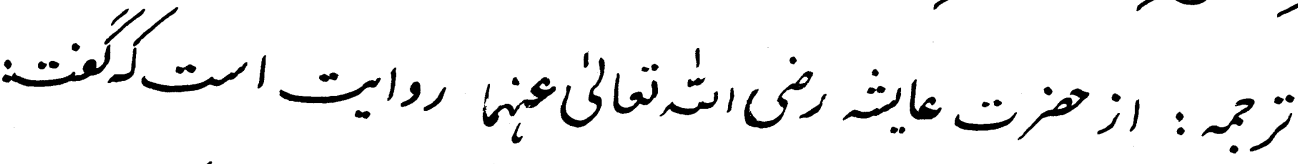

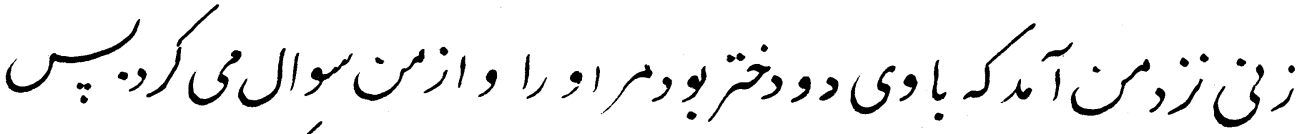

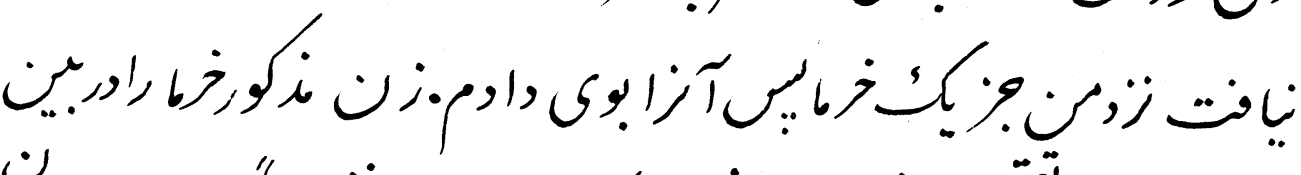

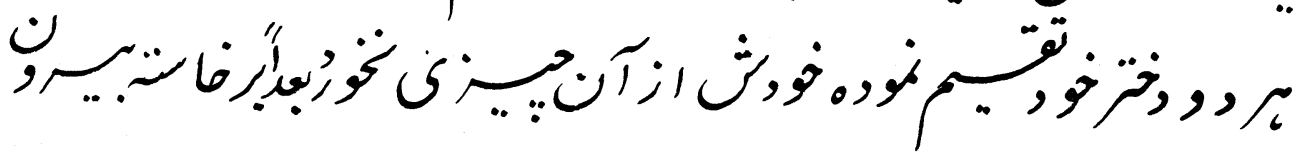

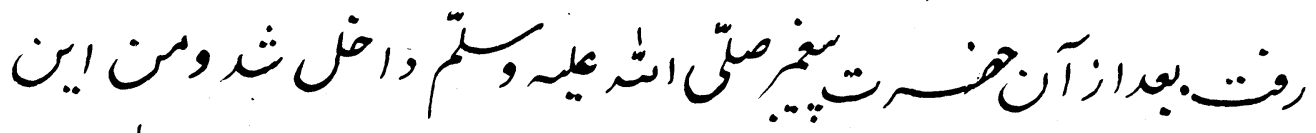

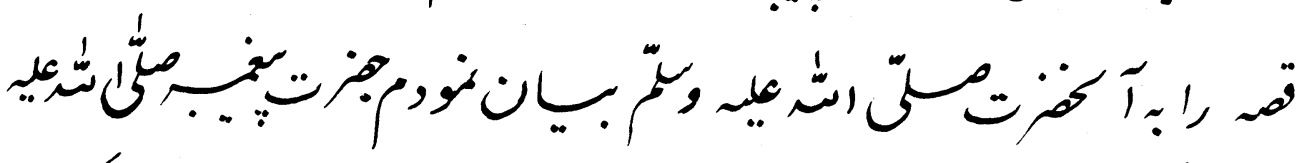

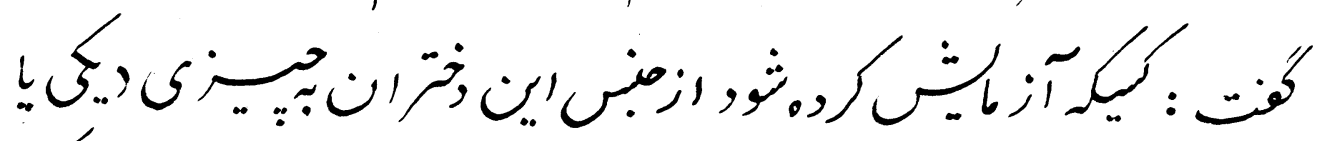

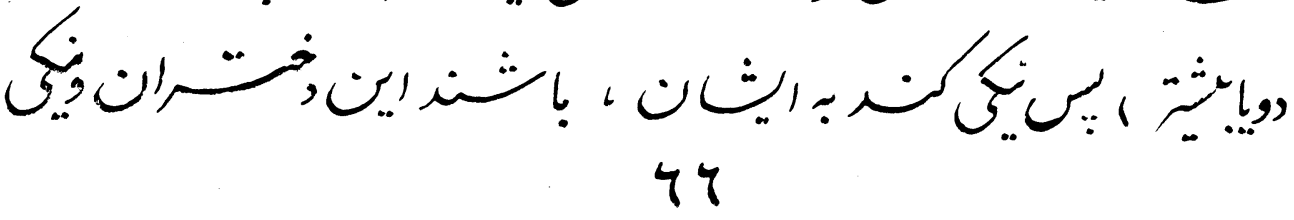




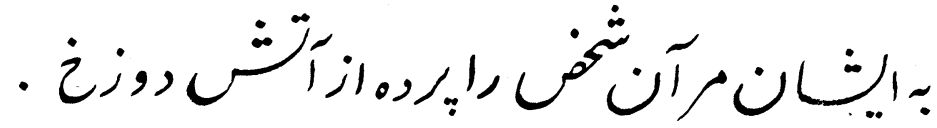

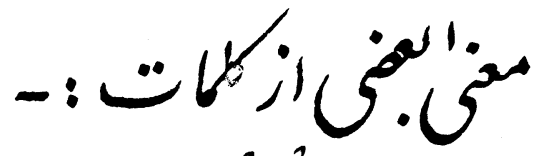

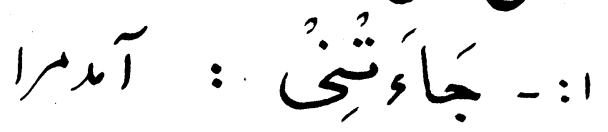

$$
\begin{aligned}
& \text { r:- ابنتان : : }
\end{aligned}
$$

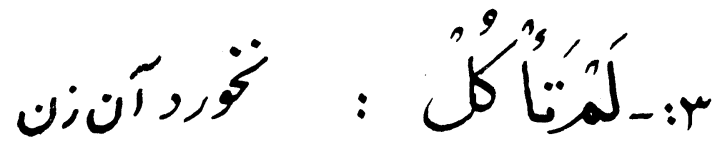

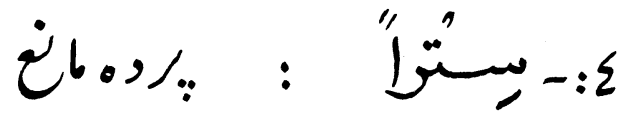

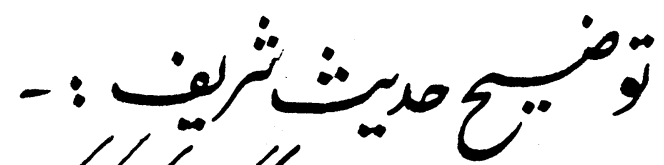

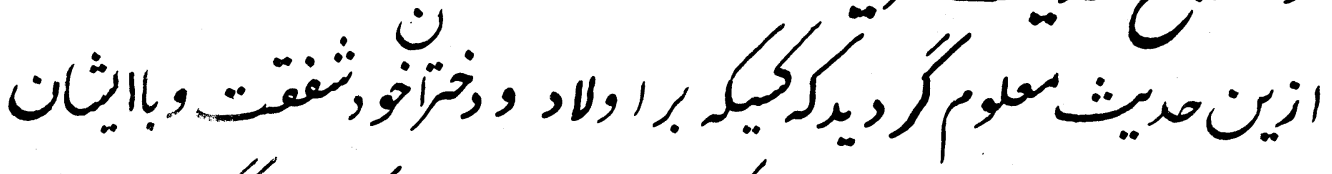

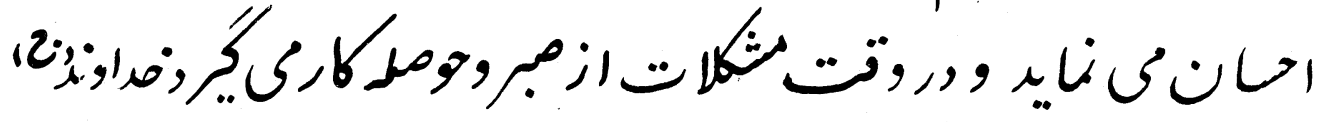

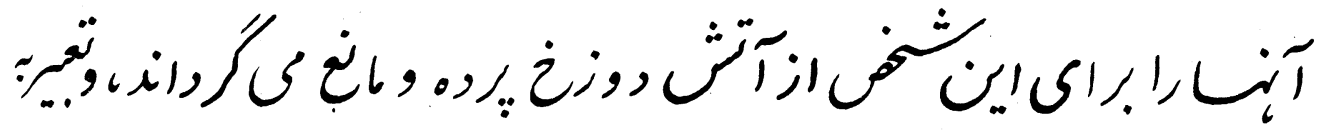

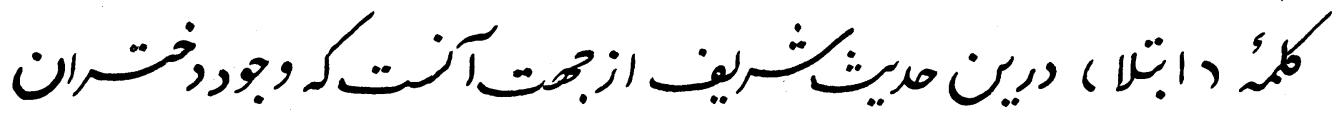

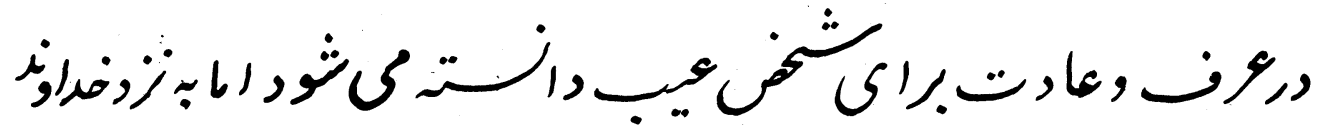

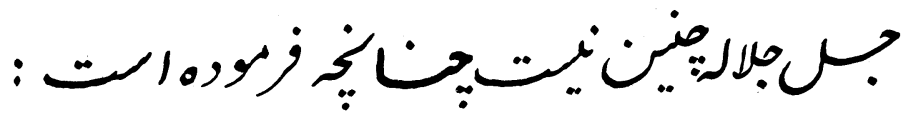

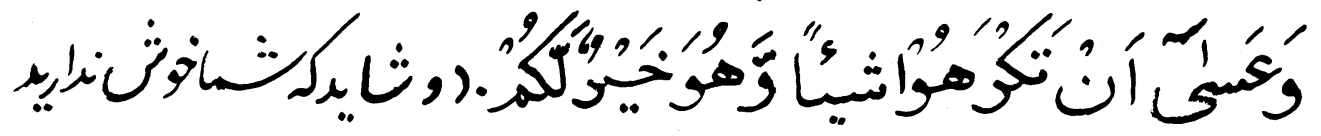




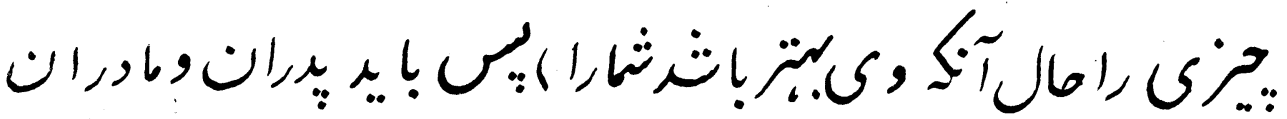

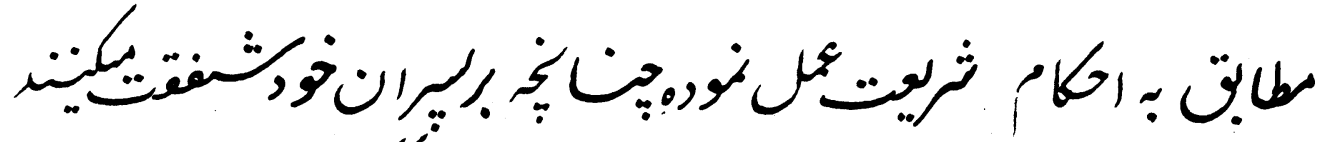

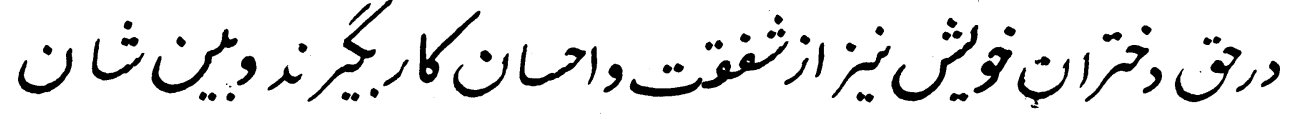

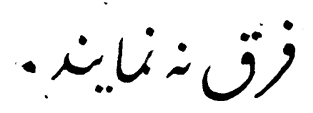

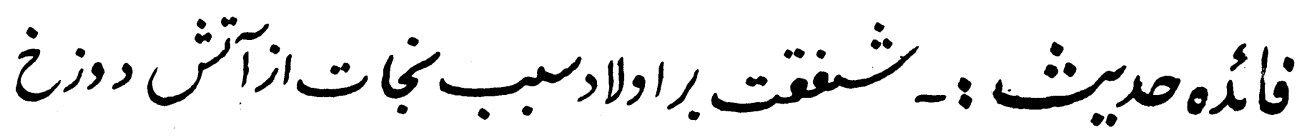

ارنت.

\section{ترين}

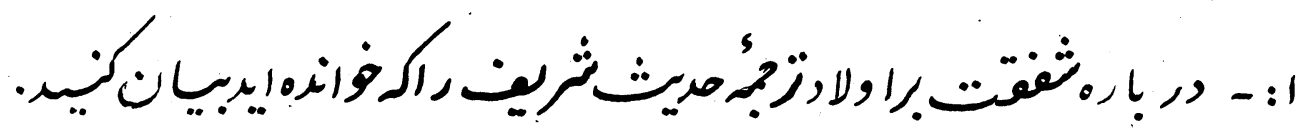

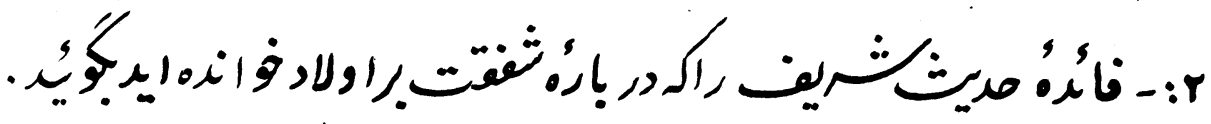

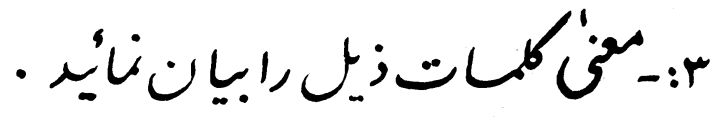

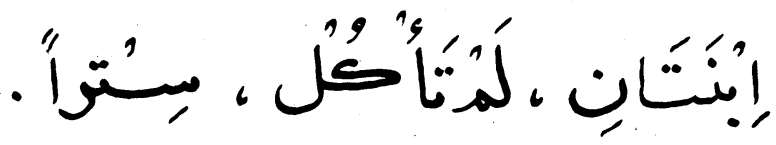




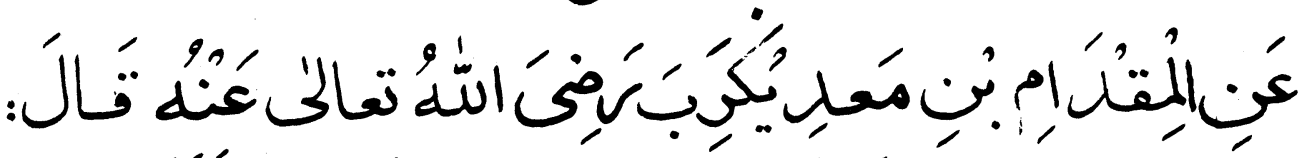

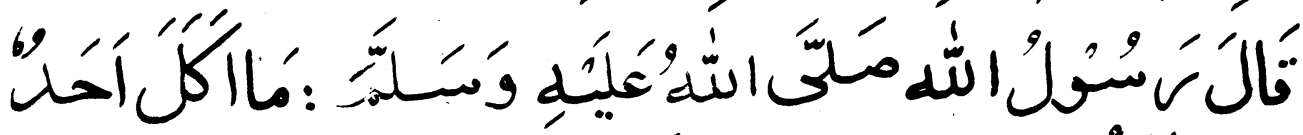

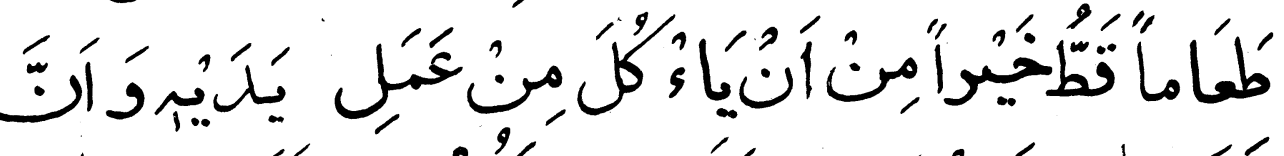

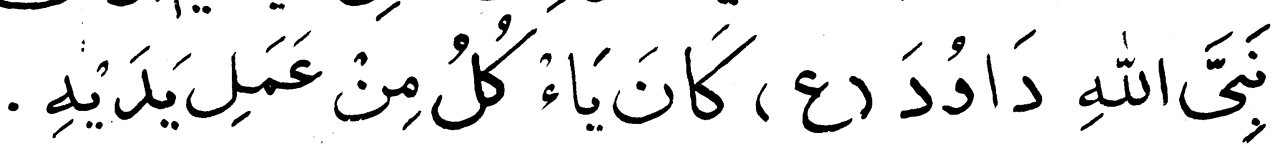
(1)

) رواءالنخارى)

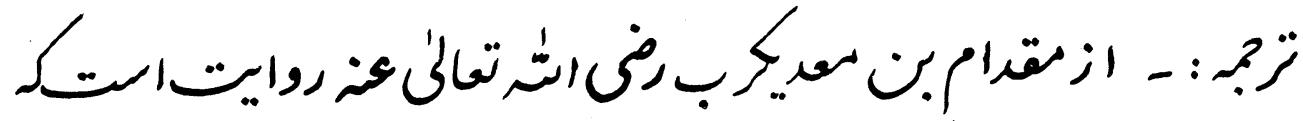

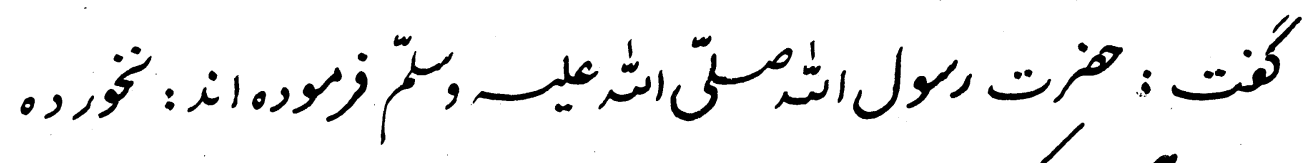

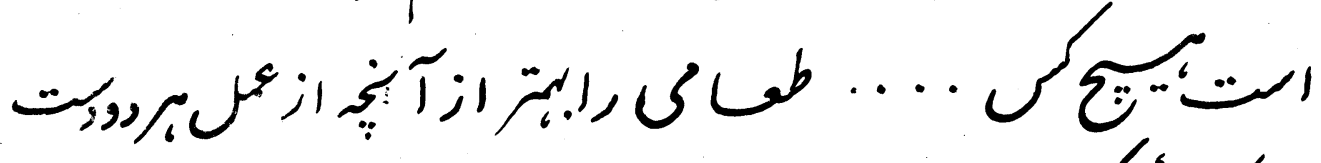

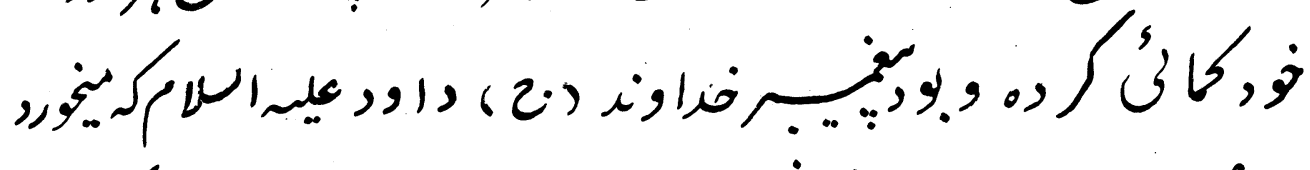

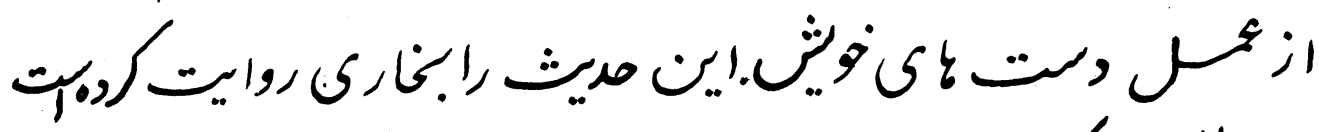

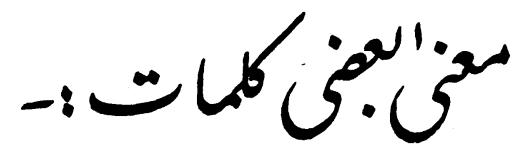

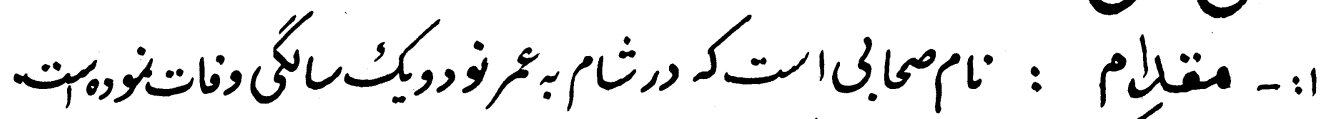

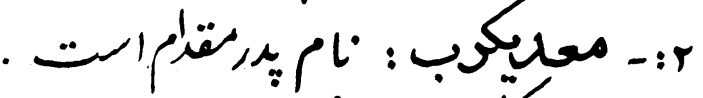

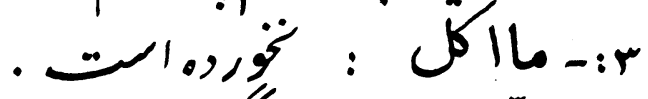
:

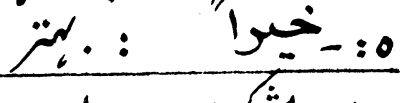
( ) (1) 


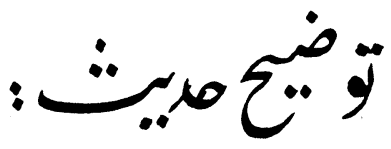

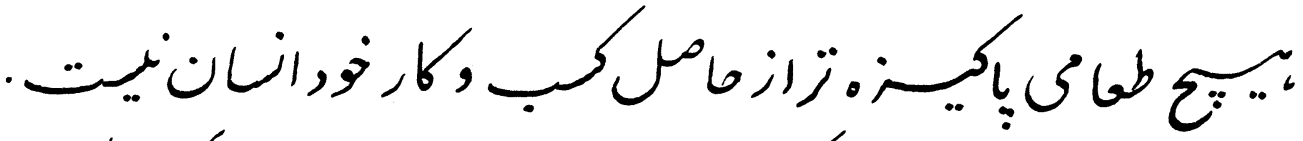

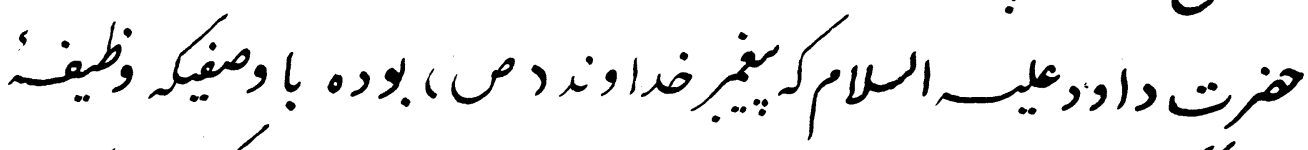

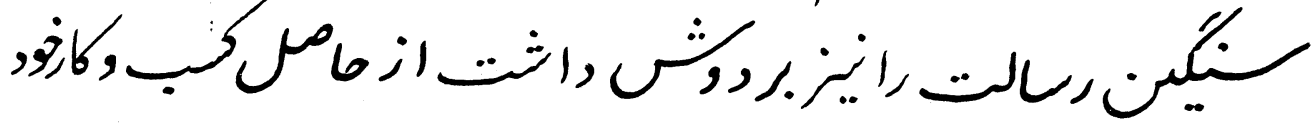

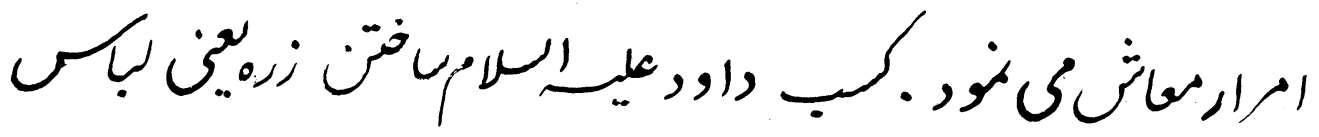

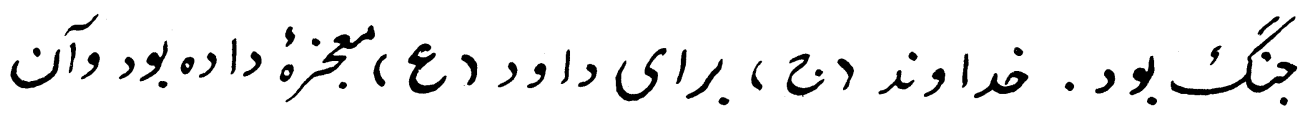

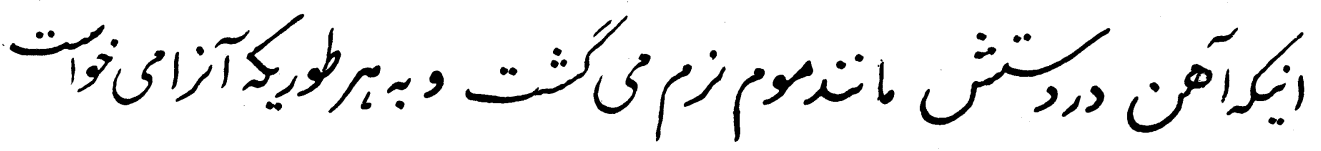

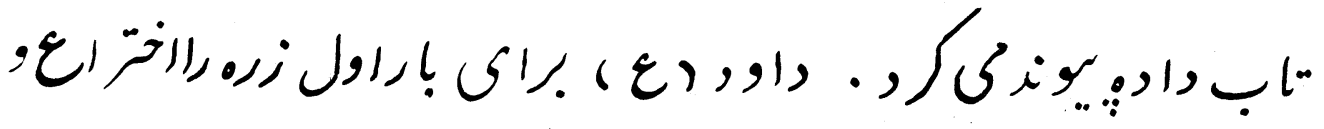

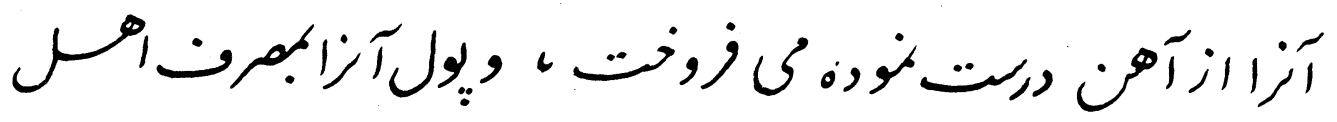

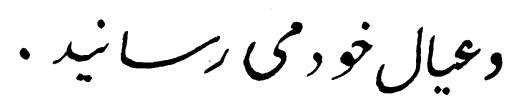

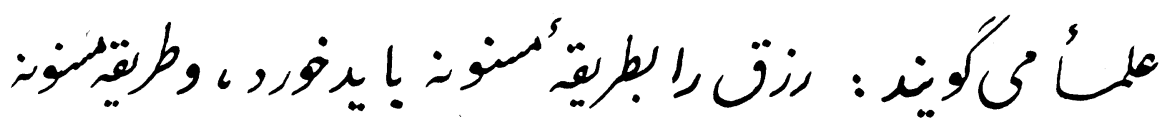

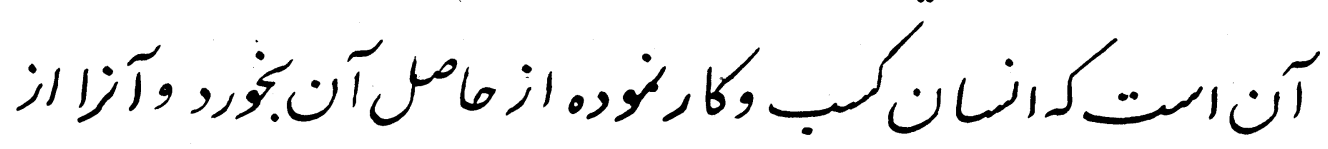

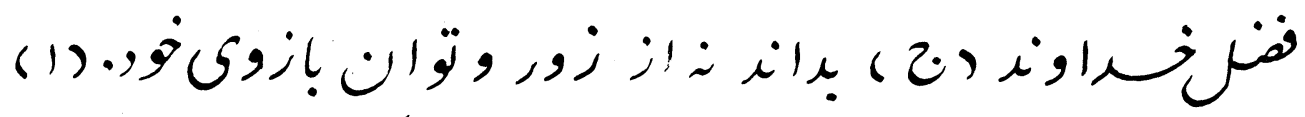

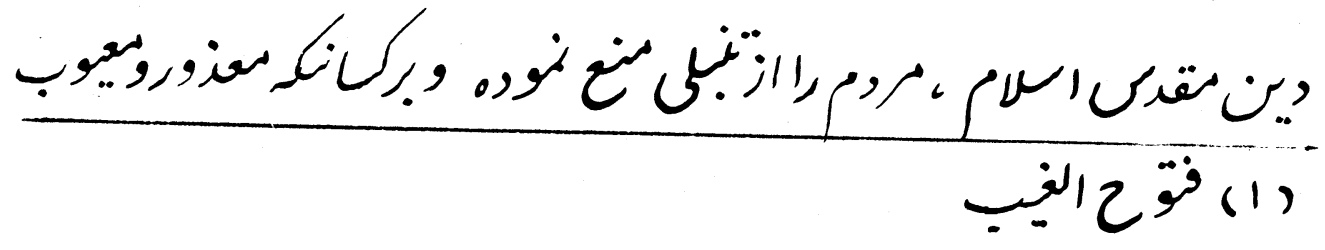




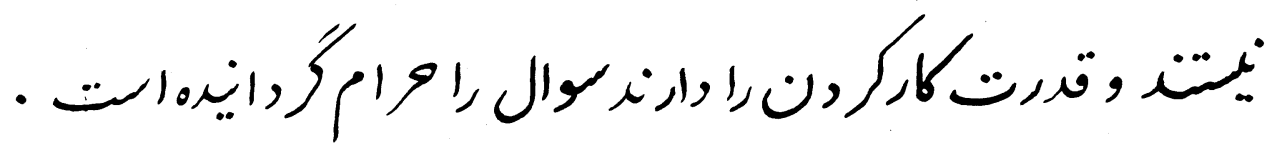

$\ddot{\sim} \ddot{\circ}$

1:-:

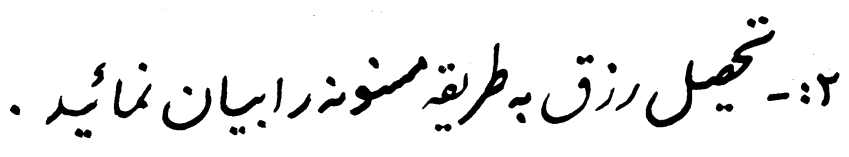

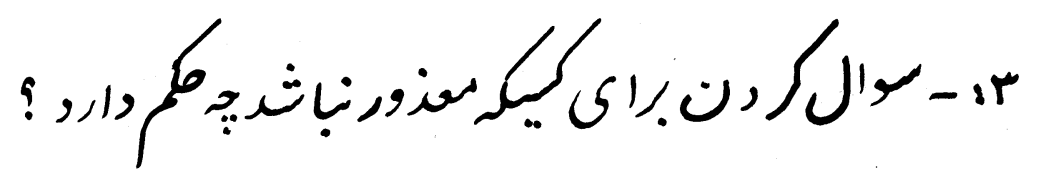

VI 


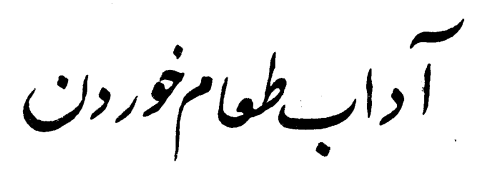

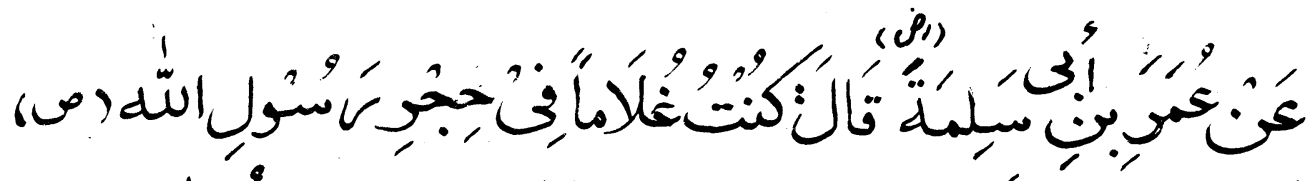

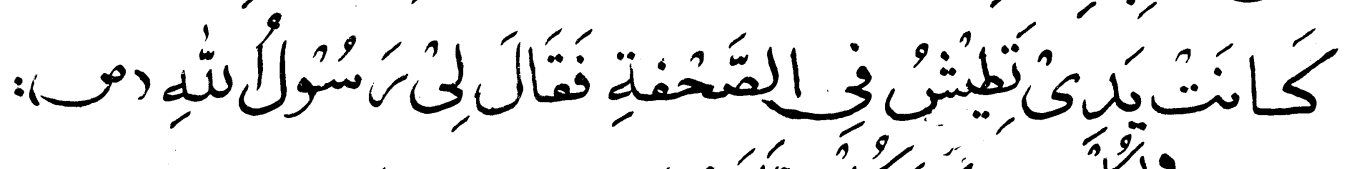

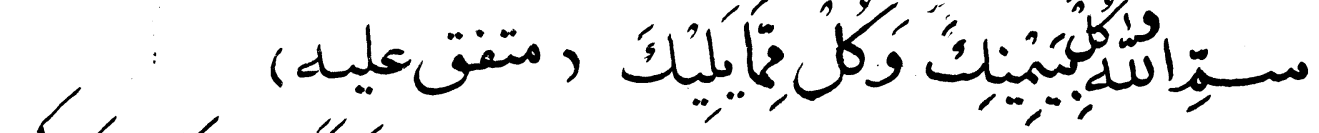

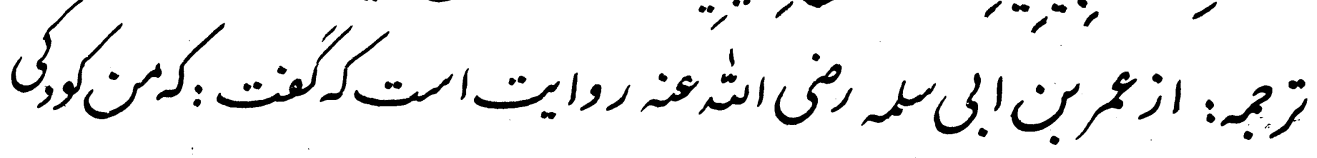

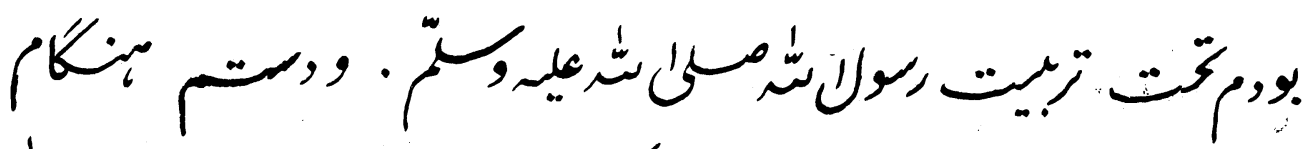

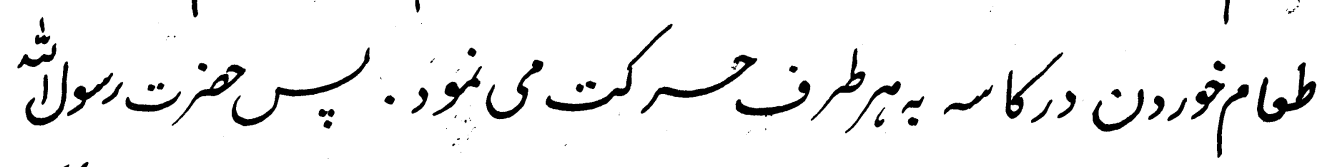

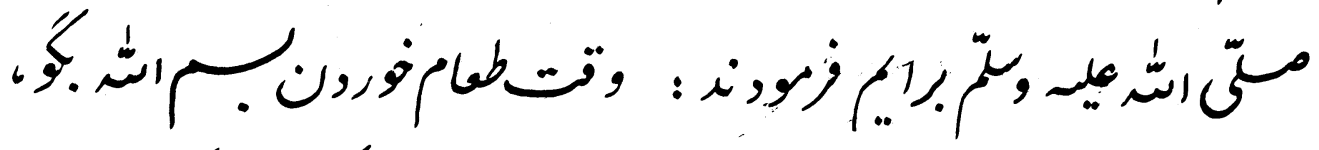

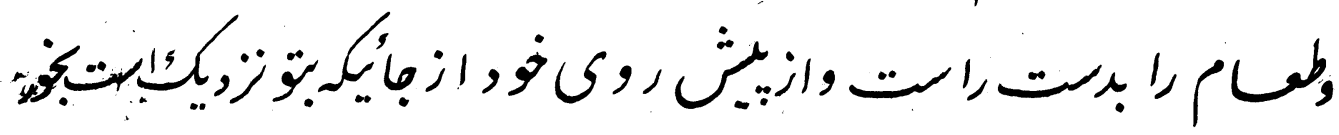

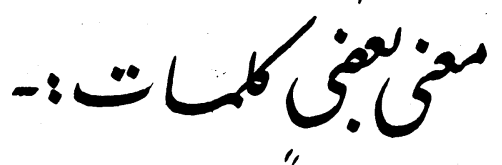
ا:- غلاماً : : :ـرخور .

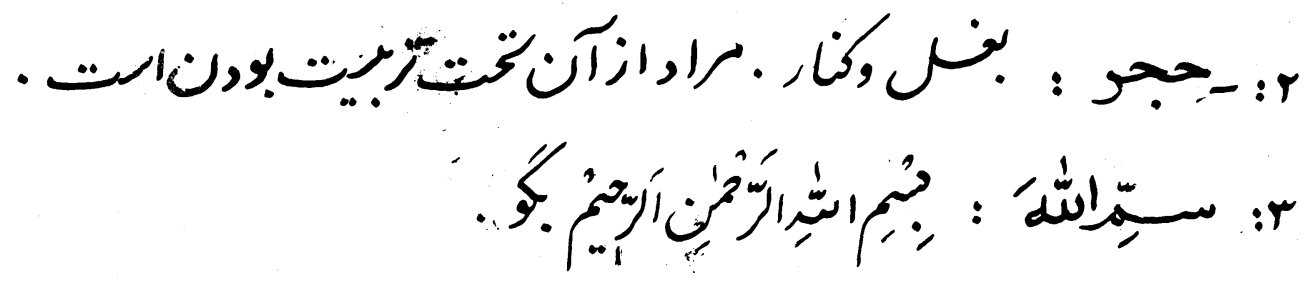




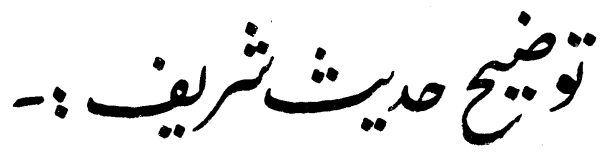

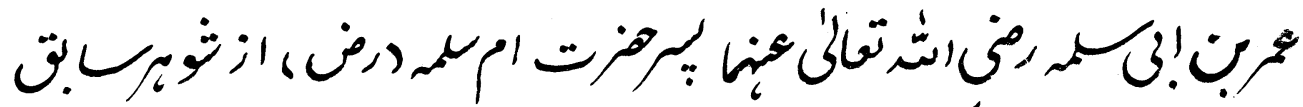

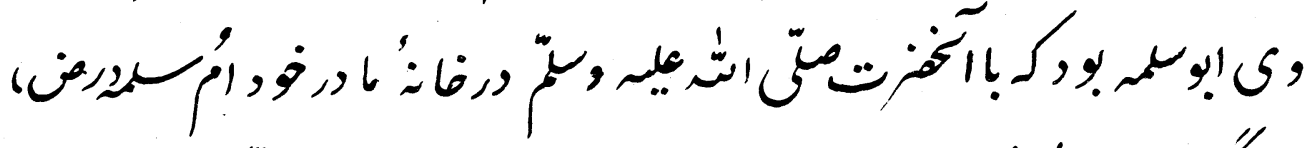

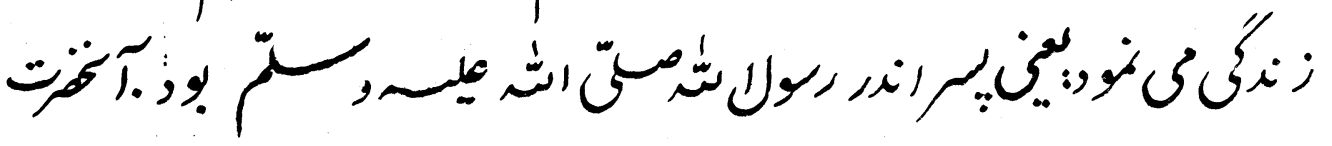

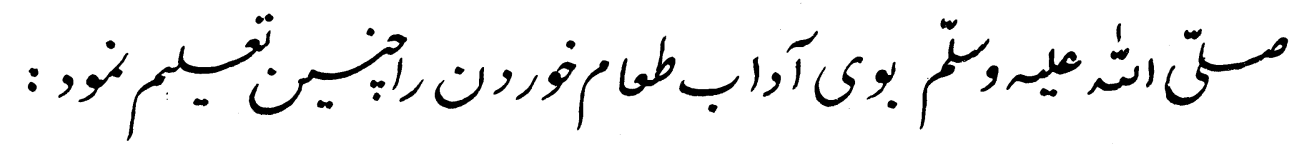

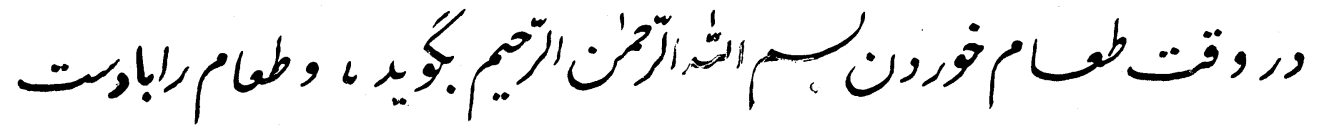

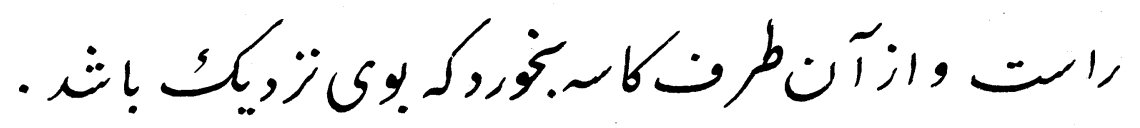

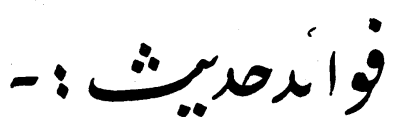

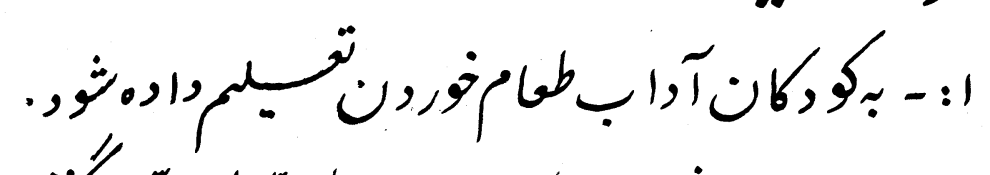

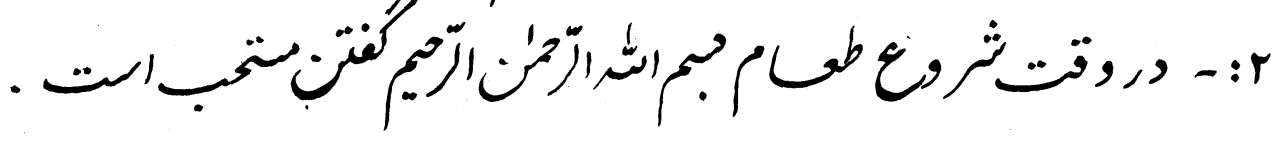

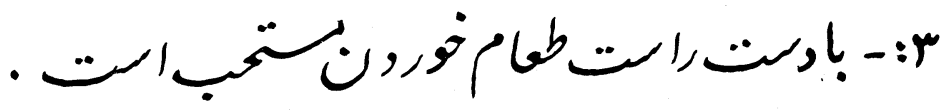

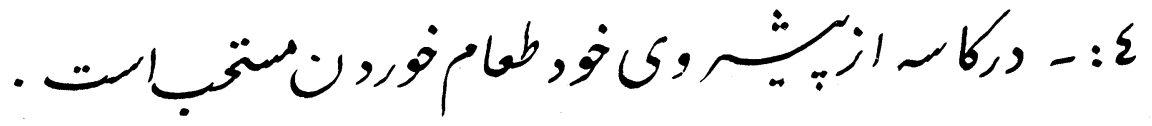

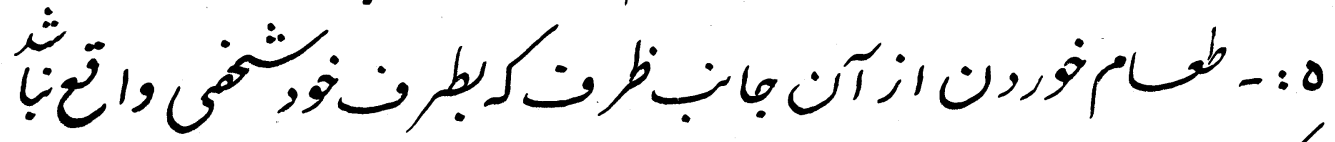

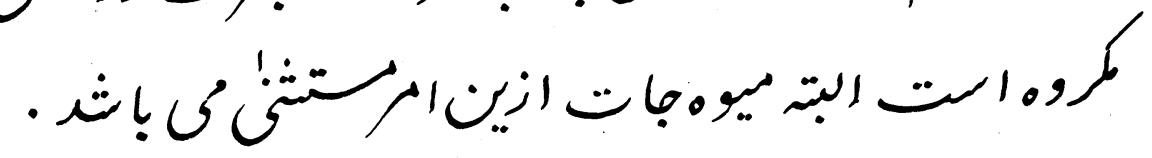




\section{آرابَبتنثين}

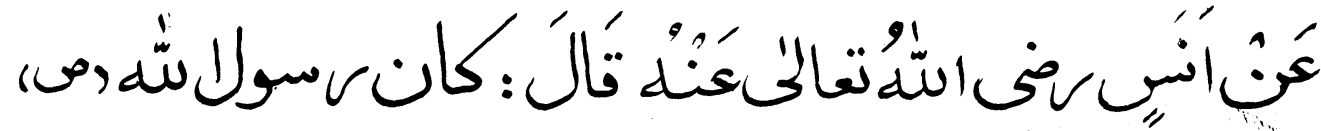

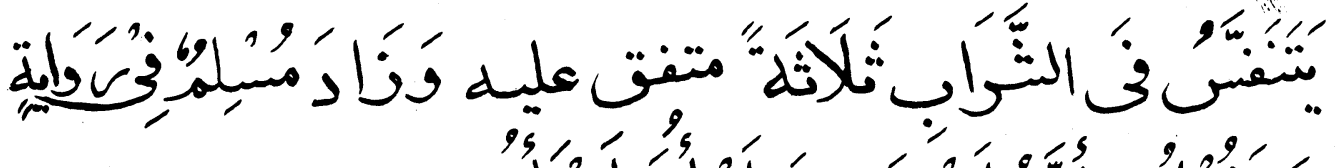

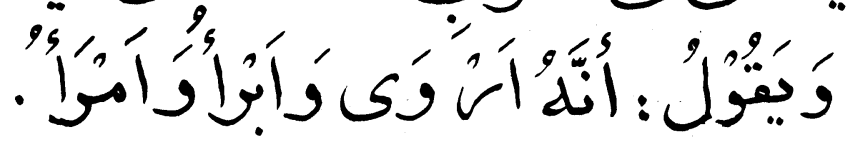

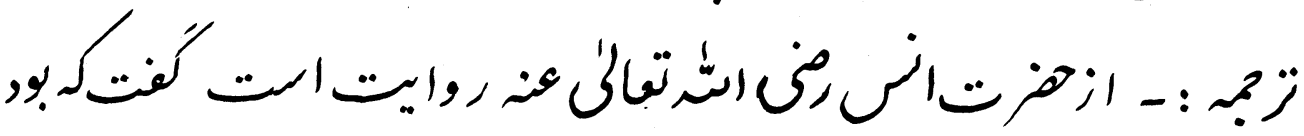

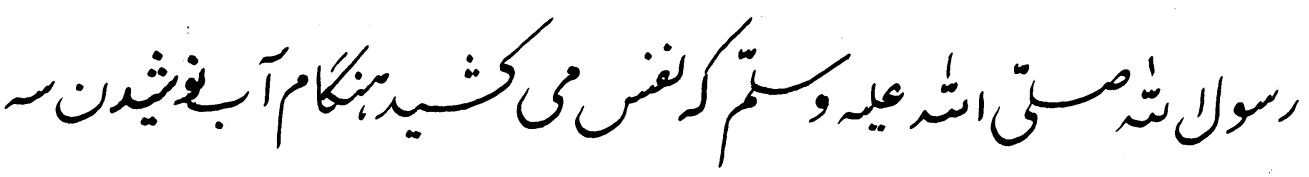

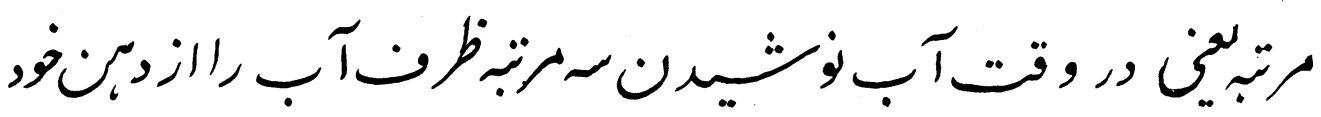

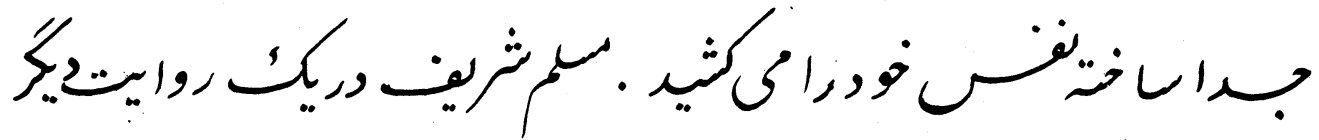

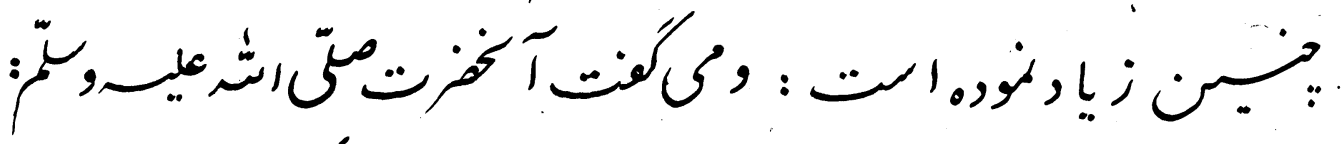

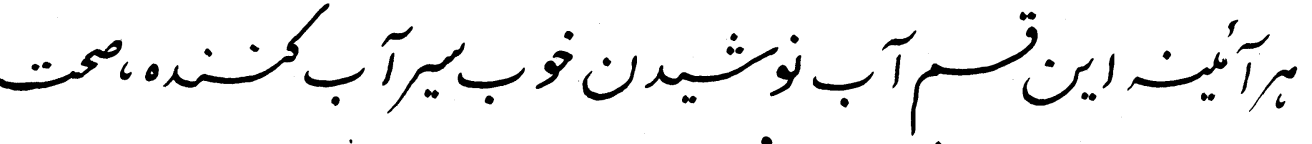

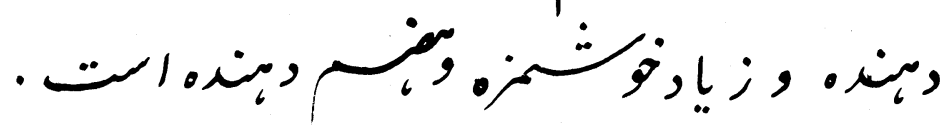

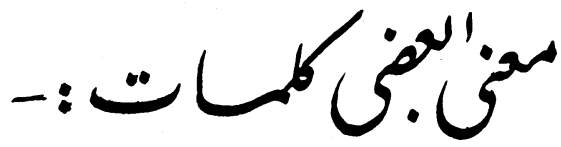

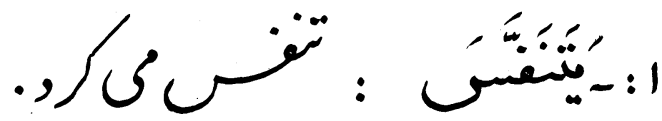

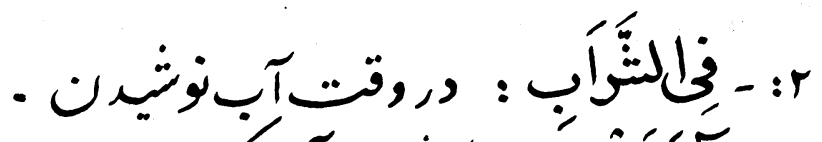

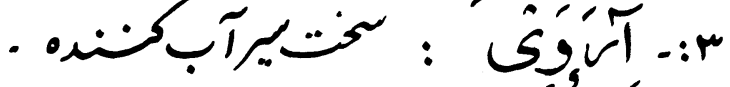

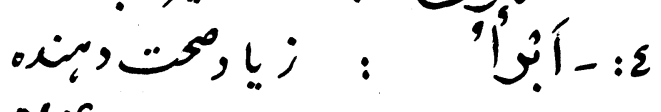

$$
\begin{aligned}
& \text { vf }
\end{aligned}
$$




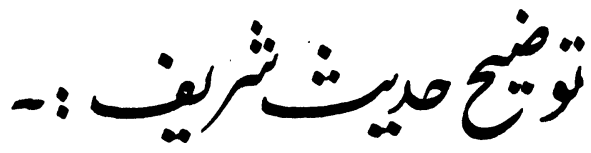

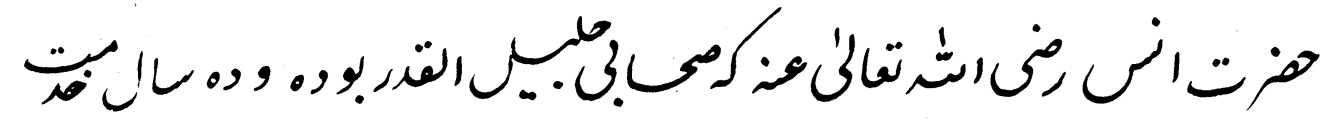

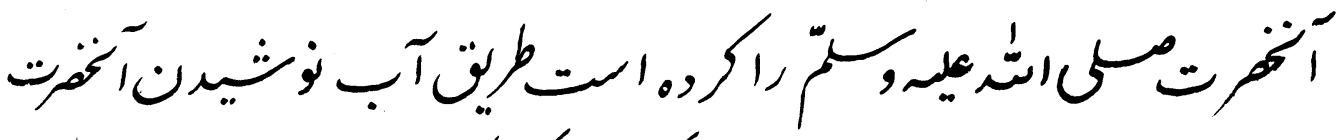

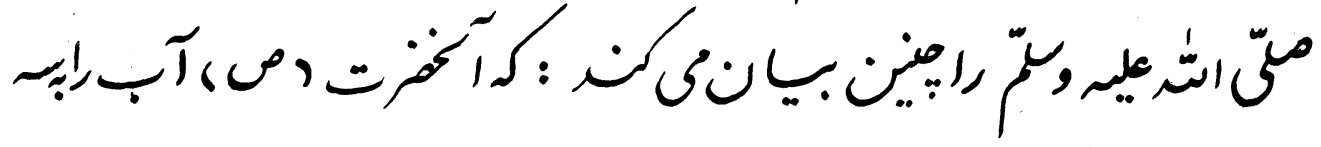

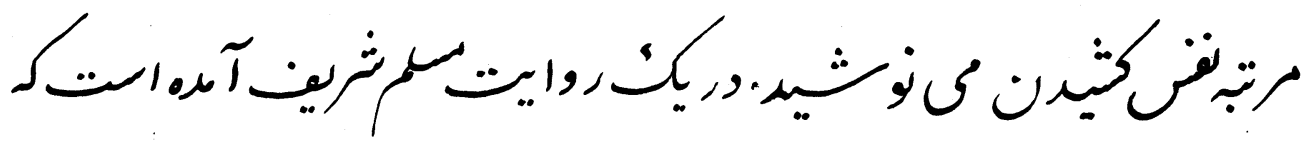

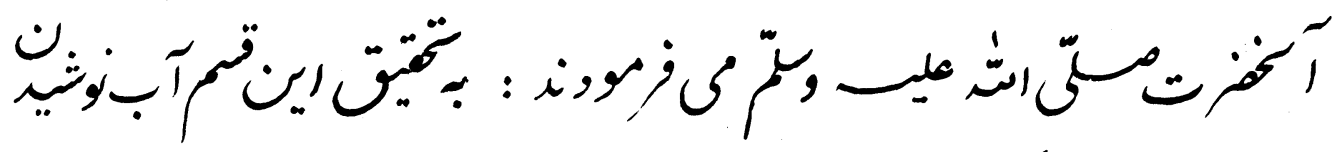

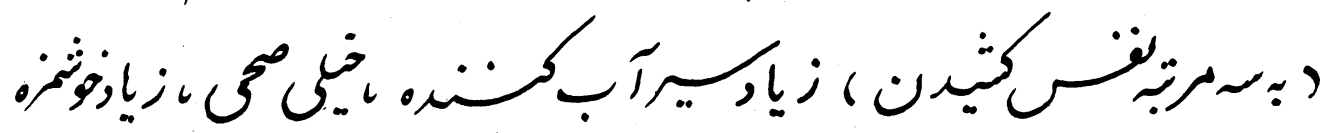

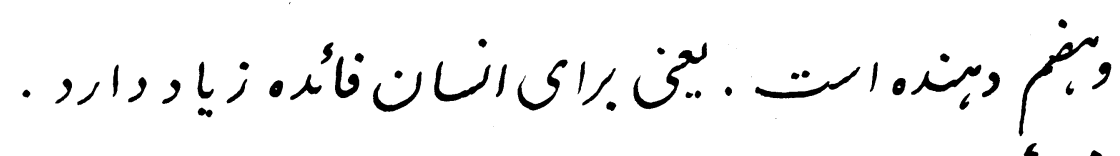

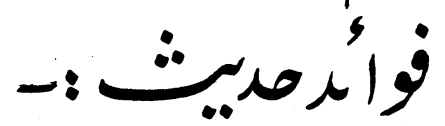

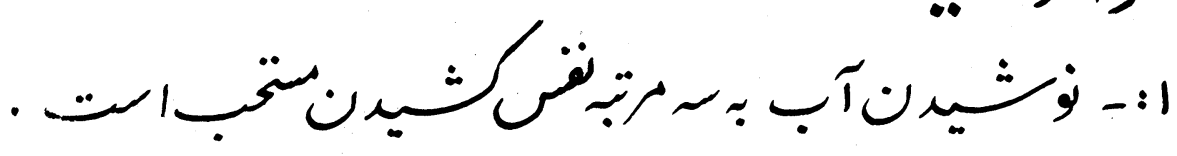

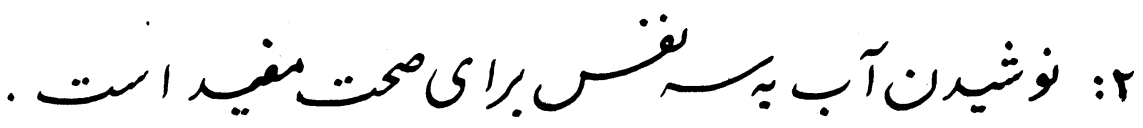

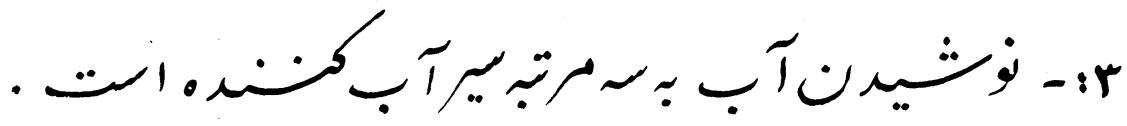




$$
\begin{aligned}
& \text { آرابحلس }
\end{aligned}
$$

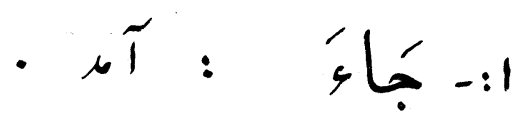

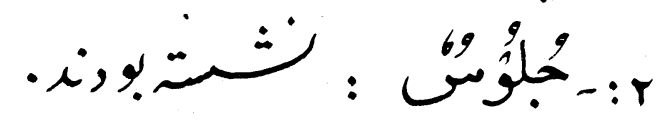

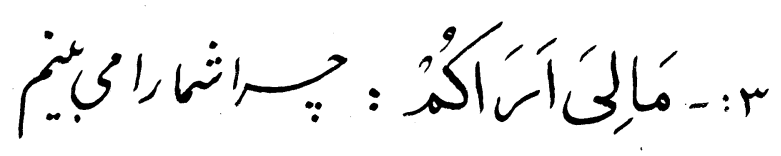

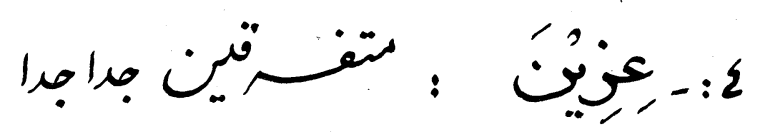

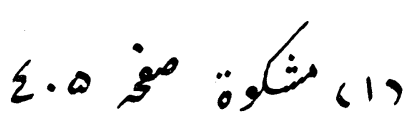




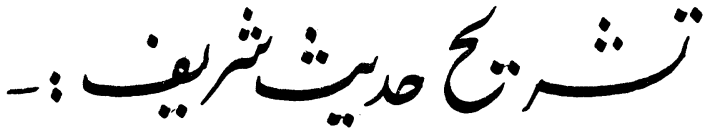

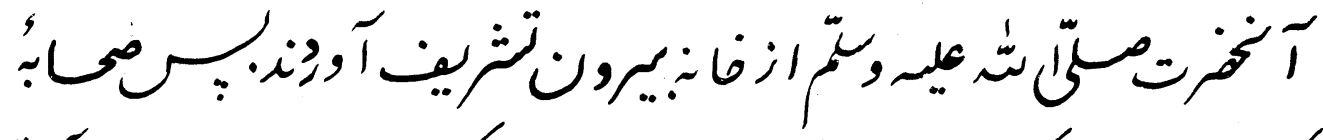

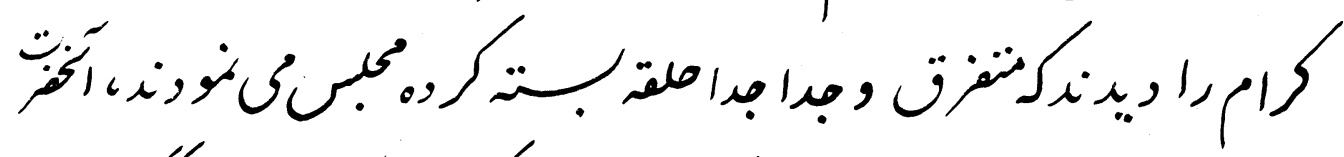

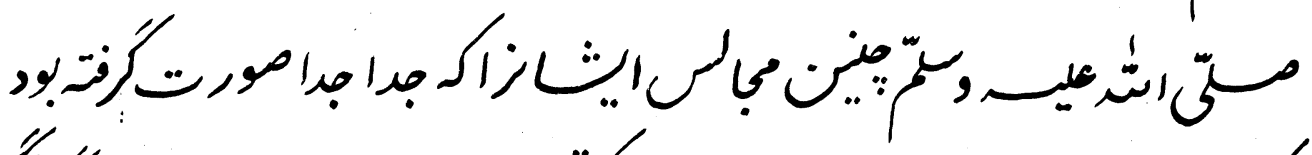

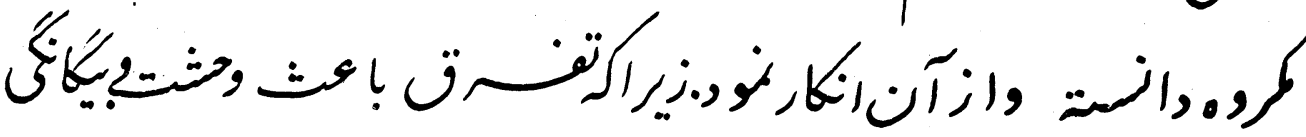

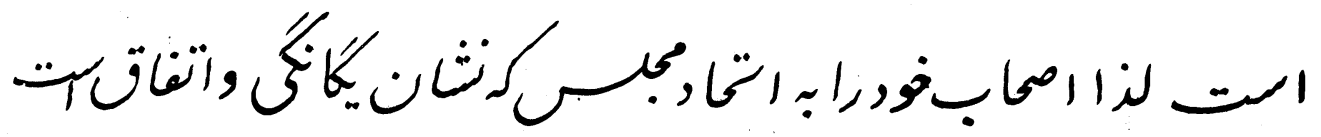

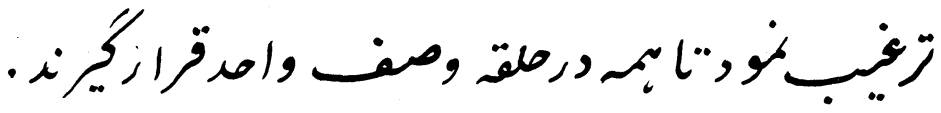

$$
\begin{aligned}
& \text { فوائرحيث :- }
\end{aligned}
$$

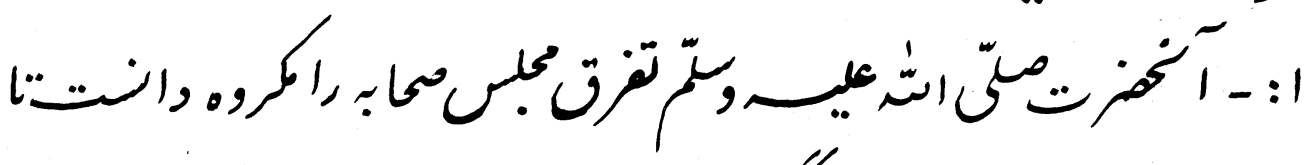

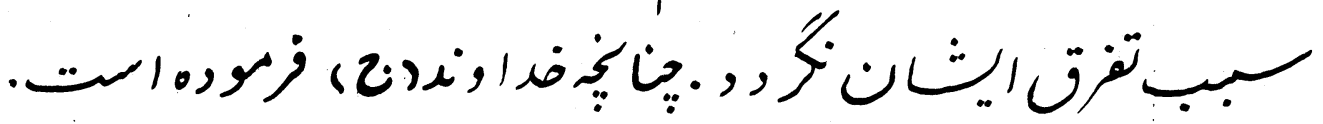

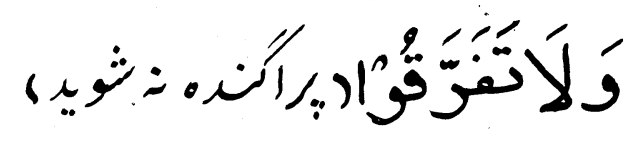

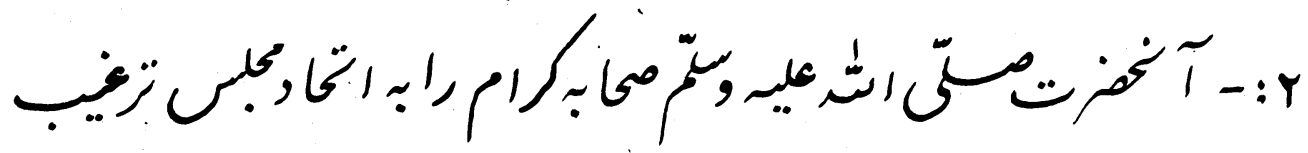

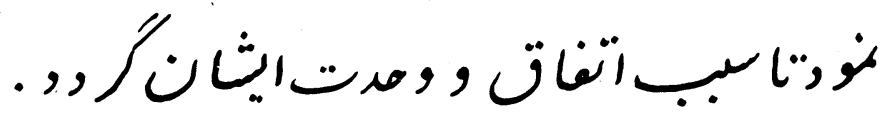

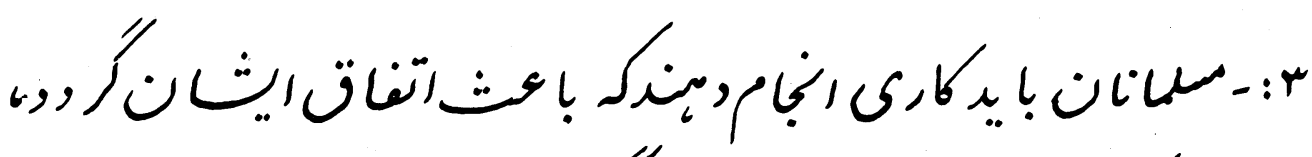

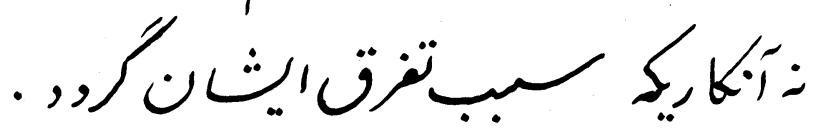

vi 
rö

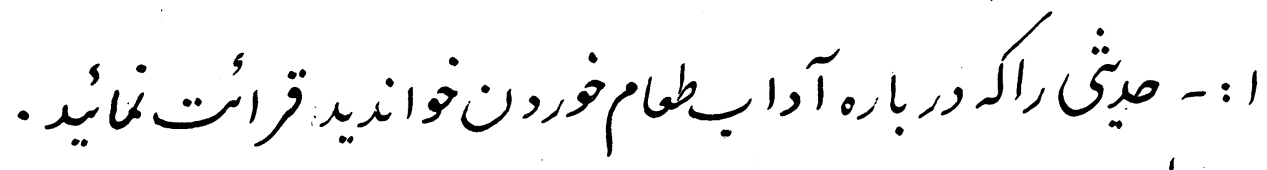

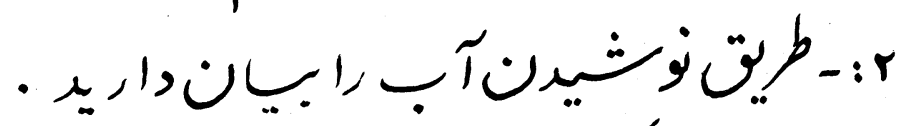

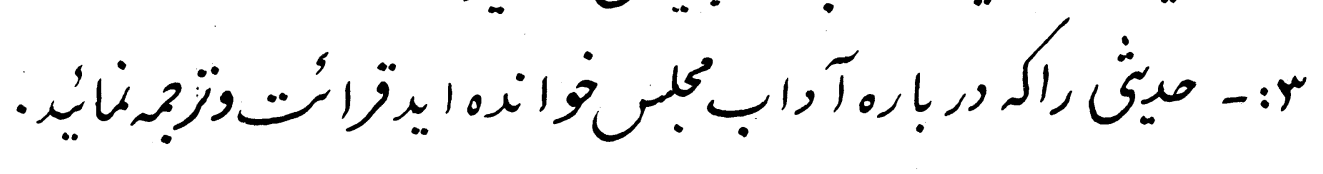

V^ 


\section{امداف نصاب تمليمى مركز تمليهى افنانستان}

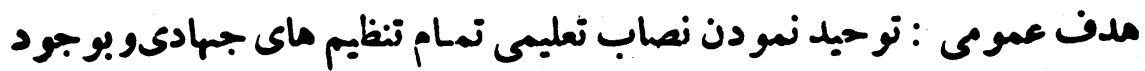

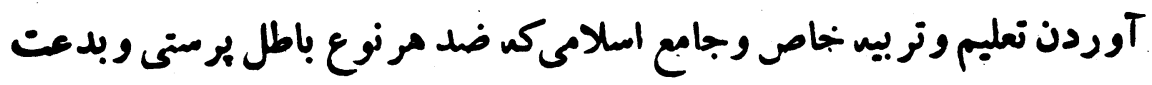

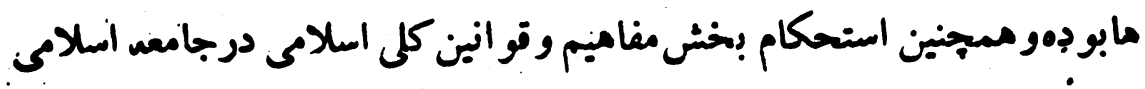
افغانستان باشد ـ

مدف خصوصى : تدريس توحيد و وحدانيت بس سباهيان اسلام و رمروان راه

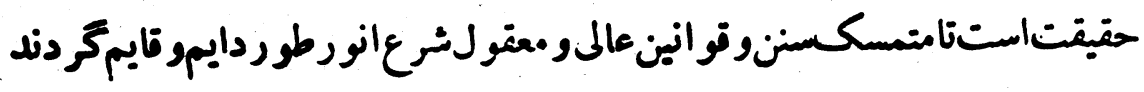

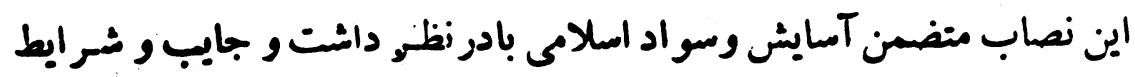

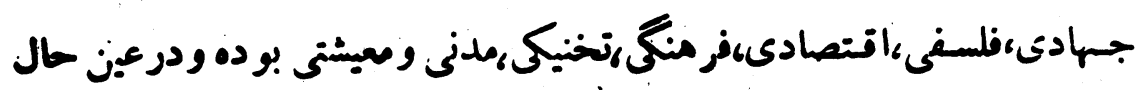

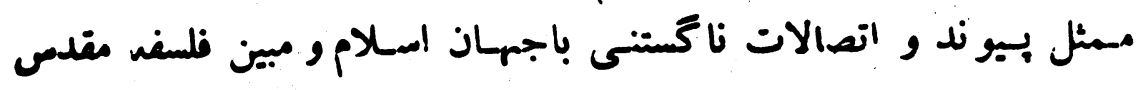

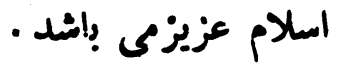

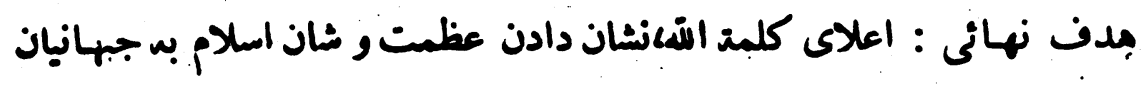

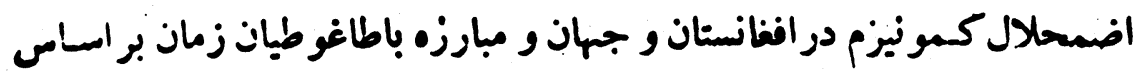

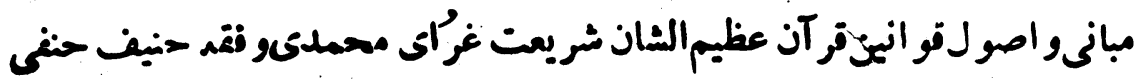
در راه حصول رضأى خداوند (ج) مى بائد .

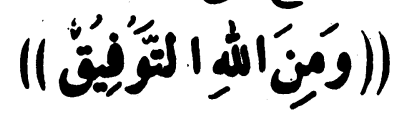

